Aus dem Department für Nutztierwissenschaften

Lehrstuhl für Systeme der Nutztierhaltung

\title{
Einfluss von Haltung und Management auf das Tierwohl in der Milchviehhaltung
}

\author{
Dissertation \\ zur Erlangung des Doktorgrades \\ der Fakultät für Agrarwissenschaften \\ der Georg-August-Universität Göttingen
}

vorgelegt von

Daniel Gieseke

geboren in Göttingen 
1. Referent: Prof. Dr. Dr. Matthias Gauly

2. Korreferent: Prof. Dr. Christoph Winckler

Tag der mündlichen Prüfung: 12. Februar 2018 
Meiner Familie 


\section{Inhaltsverzeichnis}

Inhaltsverzeichnis

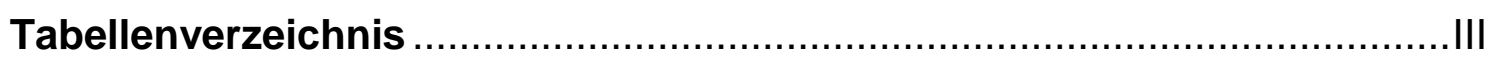

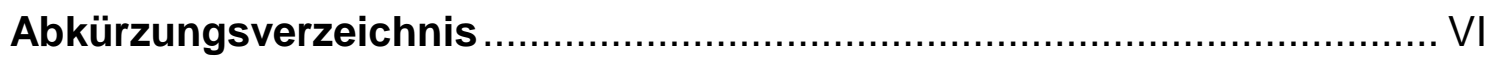

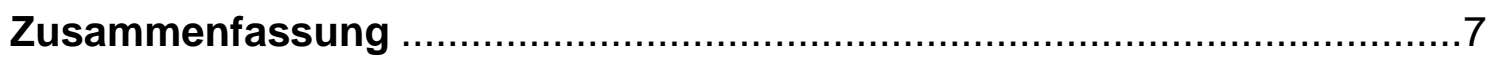

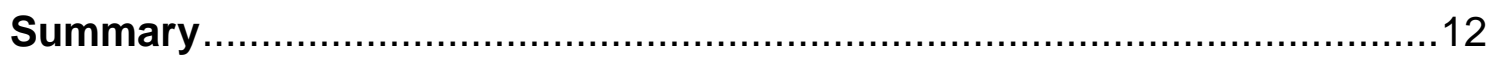

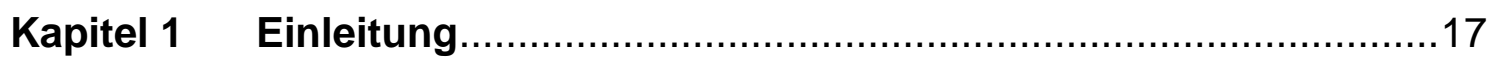

$1.1 \quad$ Hintergrund und Relevanz ……………...........................17

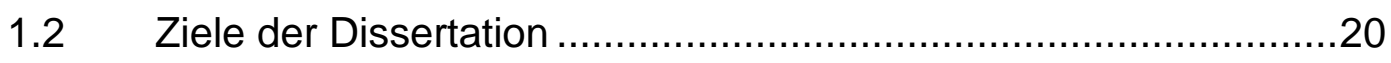

1.3 Aufbau der Dissertation........................................................20

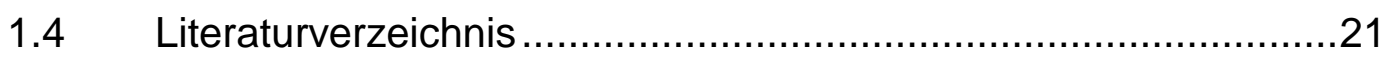

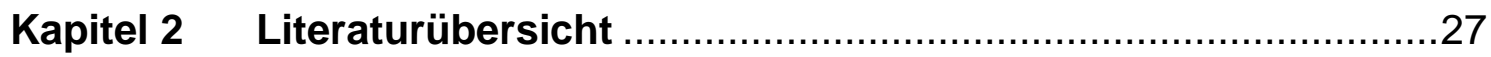

2.1 Struktur der Milchviehhaltung in Deutschland ..........................27

2.2 Tierwohlprobleme in der Milchviehhaltung .................................32

2.3 Erhebung von Tierwohl in der Nutztierhaltung ............................38

2.4 Beurteilung von Tierwohl in der Milchviehhaltung ........................41

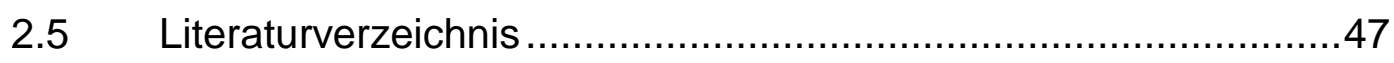

Kapitel 3 Effect of Herd Size on Animal Welfare ................................60

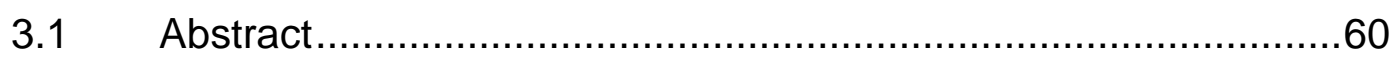

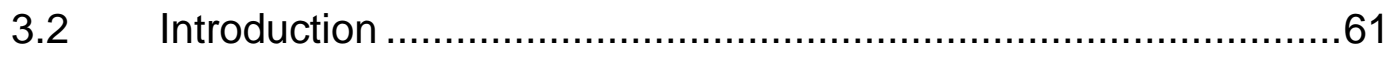

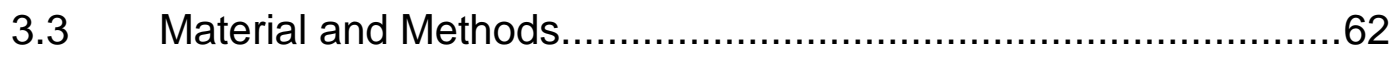

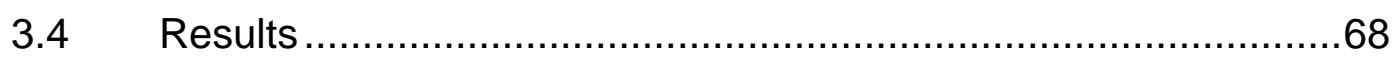

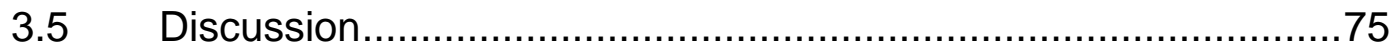

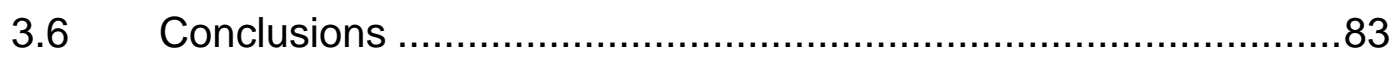

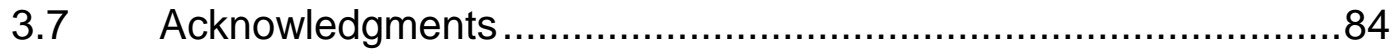

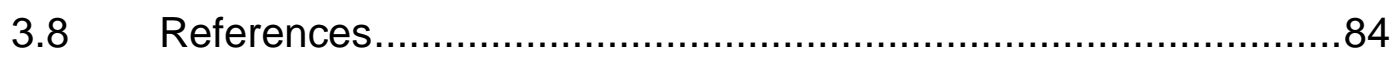

Kapitel 4 Effect of Stocking Density on Animal Welfare ......................94

$4.1 \quad$ Abstract..........................................................................

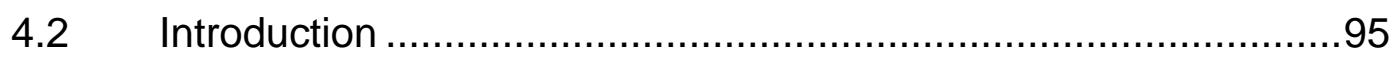

4.3 Material and Methods........................................................... 


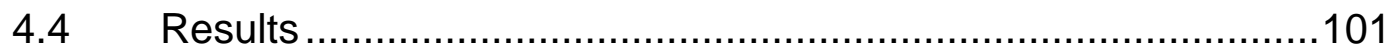

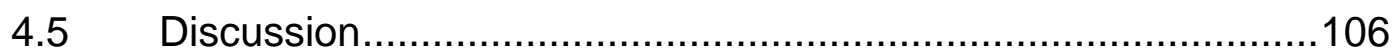

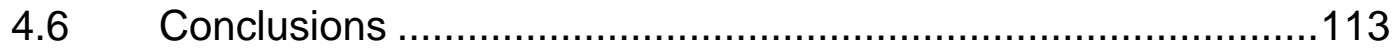

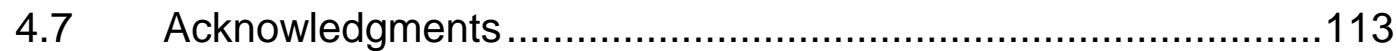

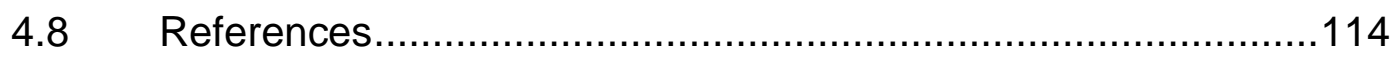

Kapitel 5 Effects of Housing and Management on Animal Welfare .....119

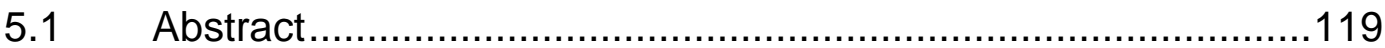

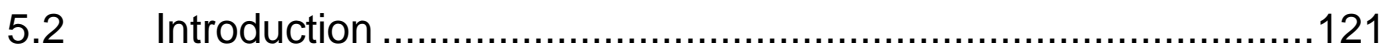

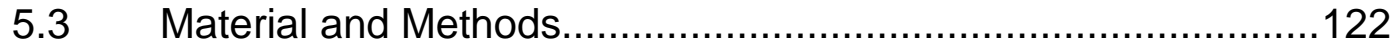

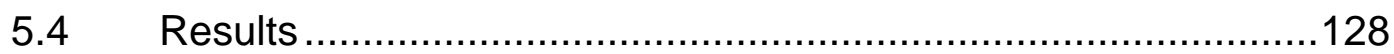

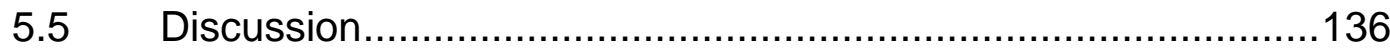

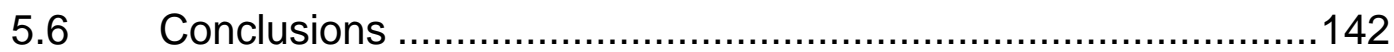

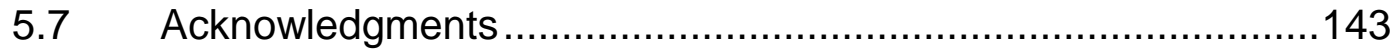

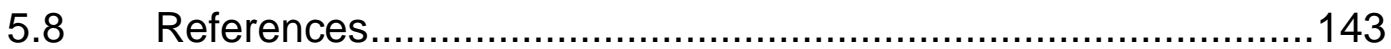

Kapitel 6 Allgemeine Diskussion...............................................151

6.1 Limitationen der Studien des Promotionsvorhabens ..................151

6.1 Einflüsse von Haltungs- und Managementfaktoren auf die Tierwohlindikatoren des Prinzips „Gute Fütterung“ .........................154

6.2 Einflüsse von Haltungs- und Managementfaktoren auf die Tierwohlindikatoren des Prinzips "Gute Haltung“.

6.3 Einflüsse von Haltungs- und Managementfaktoren auf die Tierwohlindikatoren des Prinzips "Gute Gesundheit"

6.4 Einflüsse von Haltungs- und Managementfaktoren auf die Tierwohlindikatoren des Prinzips „Artgemäßes Verhalten“ ...............165

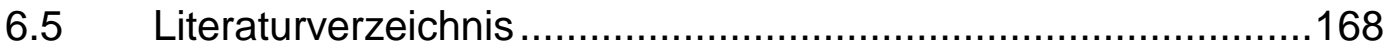

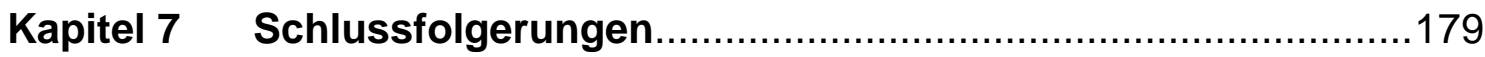

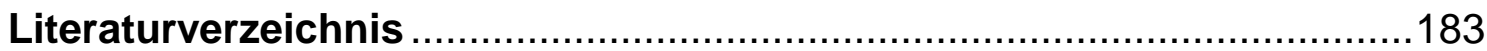

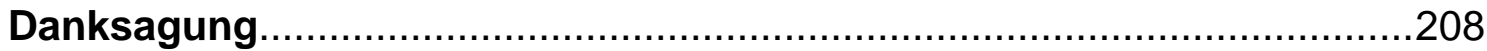

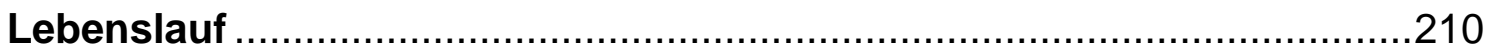

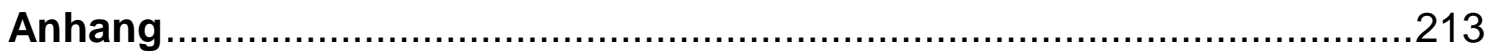

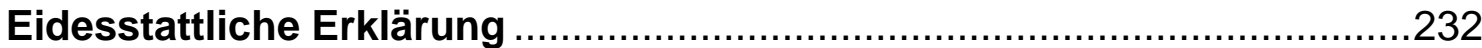




\section{Tabellenverzeichnis}

Table 2.1: Darstellung der Betriebsentwicklung in Deutschland von 2007 bis 2016. Anzahl Betriebe pro Bestandsgrößenkategorie (Quelle: Destatis, verschiedene Jahrgänge). 28

Table 2.2: Darstellung der Prinzipien, Kriterien und Indikatoren des WQP für Rinder (2012).

Table 3.3: Characteristics (farm data, performance data and housing conditions) of 80 dairy farms classified by herd size into $C 1=<100$ cows, $C 2=100-299$ cows, $\mathrm{C} 3=300-499$ cows, or $\mathrm{C} 4=\geq 500$ cows.

Table 3.4: Data collected for the assessment of the animal welfare level of dairy cows using the Welfare Quality ${ }^{\circledR}$ protocol. 66

Table 3.5: Overall classification of the Welfare Quality ${ }^{\circledR}$ assessments in season 1 (summer) and season 2 (winter) for dairy farms with $<100$ cows (C1), 100299 cows (C2), 300-499 cows (C3) or $\geq 500$ cows (C4) and $x^{2}$ test of independence.

Table 3.6: Results of the Welfare Quality ${ }^{\circledR}$ assessments at the level of principles and criteria in season 1 (summer) and season 2 (winter) for dairy farms with $<100$ cows (C1), 100-299 cows (C2), 300-499 cows (C3), or $\geq 500$ cows (C4) expressed on a 0 to 100 value scale $(0=$ poor; $100=$ good $)$. 71

Table 3.7: Results of the Welfare Quality ${ }^{\circledR}$ assessments at the level of indicators in season 1 (summer) and season 2 (winter) for dairy farms with $<100$ cows (C1), 100-299 cows (C2), 300-499 cows (C3), or $\geq 500$ cows (C4). 74

Table 4.8: Characteristics of 75 conventional dairy cattle farms classified by low (73-95\%), medium (96-103\%) or high (105-133\%) cow-to-stall ratios, low (67-104\%), medium (105-121\%) or high (122-163\%) cow-to-feeding place ratios, and high $\left(4.5-7.0 \mathrm{~m}^{2}\right)$, medium $\left(3.7-4.4 \mathrm{~m}^{2}\right)$ or low $\left(2.5-3.6 \mathrm{~m}^{2}\right)$ walking space availability. 100

Table 4.9: Results of the Welfare Quality ${ }^{\circledR}$ protocol at the level of indicators and criteria for dairy farms with low (73-95\%), medium (96-103\%) or high (105$133 \%$ ) cow-to-stall ratios 102

Table 4.10: Results of the Welfare Quality ${ }^{\circledR}$ protocol at the level of indicators and criteria for dairy farms with low (67-104\%), medium (105-121\%) or high (122-163\%) cow-to-feeding place ratios 103

Table 4.11: Results of the Welfare Quality ${ }^{\circledR}$ protocol at the level of indicators and criteria for dairy farms with high (4.5-7.0 $\left.\mathrm{m}^{2}\right)$, medium $\left(3.7-4.4 \mathrm{~m}^{2}\right)$ or low (2.5-3.6 $\left.\mathrm{m}^{2}\right)$ walking space availabilities 104 
Table 5.12: Farm characteristics (mean, standard deviation, minimum, maximum) and housing conditions (number of farms, percentage of farms) of 63 dairy cattle farms. 123

Table 5.13: Data collected for the assessment of the animal welfare level of lactating dairy cows using the Welfare Quality ${ }^{\circledR}$ protocol for dairy cattle (modified by Coignard et al. 2013).

Table 5.14: Classification of groups with high animal welfare (HW; upper tertile) and low animal welfare (LW; lower tertile) within specific animal welfare indicators or criteria (very lean cows, lesions/swellings, severe lameness, mastitis incidence, and social behavior).

Table 5.15: Potential influencing factors in univariable logistic regression analysis associated with being a herd with high welfare level (HW) within the indicator "very lean cows" 131

Table 5.16: Potential influencing factors in univariable logistic regression analysis associated with being a herd with high welfare level $(\mathrm{HW})$ within the indicator "lesions/swellings" 132

Table 5.17: Potential influencing factors in univariable logistic regression analysis associated with being a herd with high welfare level (HW) within the indicator "severe lameness" 133

Table 5.18: Potential influencing factors in univariable logistic regression analysis associated with being a herd with high welfare level (HW) within the indicator "mastitis incidence" 134

Table 5.19: Potential influencing factors in univariable logistic regression analysis associated with being a herd with high welfare level $(\mathrm{HW})$ within the criterion "social behavior" 135 


\section{Abbildungsverzeichnis}

Figure 2.1: Darstellung der Bestandsgrößenentwicklung in Deutschland von 2007 bis 2016. Anzahl Milchkühe pro Bestandsgrößenkategorie (Quelle: Destatis, verschiedene Jahrgänge).

Figure 2.2: Regionale Konzentration von Milchviehhaltung (2016) und Grünlandanteil (2010) in Deutschland (Quelle: Lindena et al., 2017). 30

Figure 2.3: Entwicklung der durchschnittlichen Milchleistung $(\mathrm{kg})$ pro Kuh und Jahr im Zeitraum von 1991 bis 2013 (Quelle: BMEL, 2017). 31

Figure 2.4: Wechselbeziehungen von Haltung, Management und Tierwohl (Quelle: Heise, 2017). 39

Figure 2.5: Modell des Welfare Quality Protokolls für Rinder von der Ebene der Tierwohlindikatoren zur Ebene des Gesamturteils 43

Figure 2.6: Beispiele für Betriebe mit verschiedenen WQP-Klassifizierungen "Exzellent“, „Verbessert“, „Akzeptabel“ und „nicht klassifiziert“ (Welfare Quality, 2012). 45 


\section{Abkürzungsverzeichnis}

\begin{tabular}{|c|c|}
\hline ABM & Animal-based-measure \\
\hline ADF & Avoidance-distance-test at the feed rack \\
\hline ADR & Arbeitsgemeinschaft Deutscher Rinderzüchter \\
\hline AIC & Akaike information criterion \\
\hline AMS & Automatic milking system \\
\hline ARCSIN & Arcus-Sinus \\
\hline AVD & Avoidance distance test \\
\hline BCS & Body condition score \\
\hline BMEL & Bundesministerium für Ernährung und Landwirtschaft \\
\hline BTSCC & Bulk tank somatic cell count \\
\hline CFR & Cow-to-feeding place ratio \\
\hline $\mathrm{Cl}$ & Confidence interval \\
\hline CSR & Cow-to-stall ratio \\
\hline DDR & Deutsche Demokratische Republik \\
\hline ECM & Energie-korrigierte Milchmenge \\
\hline EFSA & European Food Safety Association \\
\hline EU & Europäische Union \\
\hline $\mathrm{Ha}$ & Hektar \\
\hline $\mathrm{HW}$ & High welfare group \\
\hline KTBL & Kuratorium für Technik und Bauwesen in der Landwirtschaft \\
\hline LOG & Logarithmic \\
\hline LPG & Landwirtschaftliche Produktionsgenossenschaft \\
\hline LSM & Least square means \\
\hline LW & Low welfare group \\
\hline OR & Odds ratio \\
\hline PSE & Pooled standard error \\
\hline QBA & Qualitative behavior assessment \\
\hline QUE & Questionnaire \\
\hline RBM & Resource-based-measure \\
\hline SAS & Statistical analysis software \\
\hline SCC & Somatic cell count \\
\hline SD & Standard deviation \\
\hline SQRT & Square-root \\
\hline TSCHG & Tierschutzgesetz \\
\hline US & United States of America \\
\hline USDA & United States Department of Agriculture \\
\hline VIT & Vereinigte Informationssysteme Tierhaltung \\
\hline WQP & Welfare Quality Protokoll \\
\hline WSA & Wallking space availability \\
\hline
\end{tabular}




\section{Zusammenfassung}

Das Ziel dieses Promotionsvorhabens war es, die Effekte verschiedener Haltungs- und Managementfaktoren auf das Tierwohlniveau in der Milchviehhaltung zu untersuchen. Hierfür wurden insgesamt 85 konventionell wirtschaftende Milchviehbetriebe mit Hilfe des Welfare Quality ${ }^{\circledR}$ Protokolls für Rinder bewertet. Dabei handelt es sich um ein vornehmlich tierorientiertes Indikatorensystem zur Beurteilung des Tierwohls auf Betriebsebene. Die Daten wurden im Zeitraum von April 2014 bis September 2016 von einem einzelnen, erfahrenen Prüfer in Norddeutschland erhoben. Jeder Betrieb wurde zweimal im Abstand von 6 Monaten (Sommer- und Winterhalbjahr) besucht, um saisonale Effekte auf die Ergebnisse des Welfare Quality ${ }^{\circledR}$ Protokolls zu minimieren. Die durchschnittliche Bestandsgröße betrug $383 \pm 356$ (Spanne 45 - 1.629) Kühe der Rasse HolsteinFriesian. Nur Betriebe mit Liegeboxenlaufställen und ganzjähriger Stallhaltung konnten an der Studie teilnehmen, um die Vergleichbarkeit der Haltungsbedingungen gewährleisten zu können. Der vorliegende Datensatz wurde im Rahmen des Promotionsvorhabens hinsichtlich des Einflusses verschiedener Haltungsund Managementfaktoren ausgewertet (Studien I-III).

Das Ziel der ersten Studie war es, den Effekt der Bestandsgröße auf das Tierwohlniveau in Milchviehbetrieben zu untersuchen. Zu diesem Zweck wurden 80 konventionelle Milchviehbetriebe entsprechend der Anzahl Kühe auf dem Betrieb in vier Bestandsgrößenkategorien eingeteilt C1 (<100 Kühe), C2 (100-299 Kühe), C3 (300-499 Kühe) und C4 ( $\geq 500$ Kühe) und anhand verschiedener tierorientierter Indikatoren des Welfare Quality ${ }^{\circledR}$ Protokolls (WQP) für Rinder hinsichtlich inres Tierwohlniveaus bewertet. Die Daten wurden mit Hilfe eines generalisierten linearen gemischten Modells statistisch ausgewertet. Keiner der Betriebe erzielte die höchste WQP-Bewertung "exzellent". Die Mehrheit der Betriebe wurde als "verbessert" (30\%) oder "akzeptabel“ (66\%) klassifiziert, während bei sechs Erhebungen die Betriebe als "nicht klassifiziert“ (4\%) eingestuft wurden. Die durchschnittliche Troglänge pro Kuh und der prozentuale Anteil an Kühen mit Nasenund Vulvaausfluss nahmen mit steigender Bestandsgröße zu, während die Anzahl Vertreibungen pro Kuh und Stunde mit steigender Bestandsgröße abnahmen. Der prozentuale Anteil an mageren Kühen, der prozentuale Anteil an ver- 
schmutzten Unterbeinen und die durchschnittliche Abliegezeit zeigten einen kurvilinearen Zusammenhang zur Anzahl Kühe im Betrieb. Weitere Indikatoren aus dem Welfare Quality ${ }^{\circledR}$ Protokoll für Rinder wurden von der Bestandsgröße nicht beeinflusst. Zusammenfassend lässt sich festhalten, dass die Effekte der Bestandsgröße gering waren und sich die Herdengröße demzufolge nicht als Indikator für das Tierwohlniveau auf Betriebsebene eignet. Haltungsbedingungen und Managementpraktiken scheinen einen größeren Einfluss auf das Tierwohl zu haben als die Anzahl Milchkühe pro Betrieb.

Das Ziel der zweiten Studie war es, den Effekt der Bestandsdichte auf das Tierwohlniveau in der Milchviehhaltung zu untersuchen. Hierfür wurden 75 konventionelle Milchviehbetriebe mit Hilfe verschiedener tierorientierter Indikatoren des Welfare Quality ${ }^{\circledR}$ Protokolls für Rinder bewertet. Die Milchviehbetriebe wurden mittels der Berechnung von Tertilen in Bestandsdichtengruppen mit niedrigem (73-95\%), mittlerem (96-103\%) oder hohem (105-133\%) Tier-Liegeboxen-Verhältnis (TLV); niedrigem (67-104\%), mittlerem (105-121\%) oder hohem (122$163 \%)$ Tier-Fressplatz-Verhältnis (TFV) und hohem (4,5-7,0 m²), mittlerem (3,74,4 $\left.\mathrm{m}^{2}\right)$ oder niedrigem (2,5-3,6 $\left.\mathrm{m}^{2}\right)$ Verkehrsflächenangebot (VFA) klassifiziert. Die Daten wurden mit Hilfe eines generalisierten linearen gemischten Modells statistisch ausgewertet. Die Anzahl schwer lahmer Kühe war höher in Betrieben mit hohem (37,7\%), im Vergleich zu Betrieben mit niedrigem (22,3\%) bis mittlerem $(23,0 \%)$ TLV. Der prozentuale Anteil Kühe mit Nasenausfluss unterschied sich zwischen Betrieben mit hohem (19,1\%) und Betrieben mit niedrigem (25,7\%) TLV. Die meisten Kopfstöße pro Kuh und Stunde wurden in Betrieben mit niedrigem $(0,6)$, im Vergleich zu Betrieben mit mittlerem und hohem $\operatorname{TFV}(0,3)$ aufgezeichnet. Die Punkte innerhalb des Kriteriums „Positive Emotionen“ waren höher in Betrieben mit mittlerem (85,1 Punkte) und hohem (83,9 Punkte) im Vergleich zu Betrieben mit niedrigem (74,1 Punkte) TFV. Der höchste prozentuale Anteil an schwer lahmen Kühen wurde in Betrieben mit mittlerem $(31,2 \%)$ bis hohem $(33,1 \%)$, während der niedrigste prozentuale Anteil in Betrieben mit niedrigem $(18,8 \%)$ VFA beobachtet wurde. Im Gegensatz dazu wurde der höchste prozentuale Anteil an Kühen mit Mastitis $(23,8 \%)$ in Betrieben mit niedrigem, im Vergleich zu Betrieben mit mittlerem VFA $(17,8 \%)$ nachgewiesen. Weitere Indikato- 
ren aus dem Welfare Quality ${ }^{\circledR}$ Protokoll für Rinder wurden von der Bestandsdichte nicht beeinflusst. Zusammenfassend lässt sich festhalten, dass die vorliegende Studie keine konsistente Beziehung zwischen der Bestandsdichte und dem Tierwohl bei Milchkühen indiziert. Einige Tierwohlindikatoren fielen in Betrieben mit höheren Bestandsdichten besser aus, während andere in Betrieben mit niedrigeren Bestandsdichten bessere Werte erzielten. Folglich kann die Bestandsdichte allein nicht als geeigneter Indikator für das Tierwohlniveau auf Betriebsebene verwendet werden. Die in dieser Übersichtstudie untersuchten Parameter der Bestandsdichte (TLV, TFV, VFA) haben das Potential, Tierwohl von Milchkühen positiv oder negativ zu beeinflussen und sollten daher bei der Optimierung der Haltung und des Managements in Milchviehbetrieben gleichermaBen berücksichtigt werden.

Das Ziel der dritten Studie war es, den Effekt von Haltungs- und Managementfaktoren auf Tierwohlindikatoren bei Milchkühen mit Hilfe eines BenchmarkingAnsatzes zu untersuchen. Insgesamt wurden 63 konventionelle Milchviehbetriebe mit Hilfe mehrerer tierorientierter Indikatoren des Welfare Quality ${ }^{\circledR}$ Protokolls für Rinder bewertet. Fünf Tierwohlindikatoren (magere Kühe, Läsionen/Schwellungen, schwere Lahmheit, Mastitisinzidenz und Sozialverhalten) wurden ausgewählt, weil sie verschiedene Aspekte des Tierwohls reflektieren. Zusätzlich wurden die vorherrschenden Haltungsbedingungen (wie z.B. Liegeboxendesign oder Laufflächengestaltung) dokumentiert und die Betriebsleiter hinsichtlich ihrer Managementmaßnahmen interviewt. Die Milchviehbetriebe wurden als Gruppen mit hohem Tierwohl (HW) und Gruppen mit niedrigem Tierwohl (LW) kategorisiert, indem die oberen und unteren Tertile für jeden einzelnen Tierwohlindikator separat kalkuliert wurden. Beide Gruppen wurden hinsichtlich ihrer Haltungsbedingungen oder Managementpraktiken mit Hilfe einer uni- und multivariablen logistischen Regressionsanalyse verglichen. Höhere Fütterungsfrequenzen ( $>1$ vs. $1 \mathrm{x} / \mathrm{Tag}$ ), die Fütterung einer Totalen-Misch-Ration (vs. einer Partiellen-Misch-Ration), Fütterungsgruppen (vs. 1 Fütterungsgruppe) und die Kraftfuttermenge ( $>8,5 \mathrm{vs}$. $<8,5 \mathrm{~kg} / \mathrm{Tag}$ ) waren positiv mit einem niedrigeren prozentualen Anteil magerer Kühe assoziiert $(p<0,20)$. 
Ein niedrigerer Anteil von schwer lahmen Kühen wurde mit einem mittleren TierLiegeplatz-Verhältnis (95-105 vs. $<95$ und >105 Kühe/100 Boxen), höheren Klauenpflegefrequenzen ( $>2,5$ vs. $<2,5$ x/Jahr), regelmäßiger Anwendung eines Klauenbades (vs. keine Anwendung), planbefestigter Boden (vs. Spaltenboden) und Gummiböden (vs. keine Gummiböden) in Verbindung gebracht $(p<0,20)$. Eine niedrigere Anzahl an Tieren mit einem hohen Gehalt somatischer Zellen in der Milch (>400.000 Zellen/ml) war positiv mit dem Melken in einem Melkstand (vs. Automatisches Melksystem), niedrigeren Melkfrequenzen (2 vs. $>2$ x/Tag) und routinemäßiger Anwendung eines antibiotischen Trockenstellers (vs. bedarfsweise) assoziiert $(p<0,20)$. Assoziationen zwischen einem niedrigen Niveau von agonistischen Interaktionen und der Integration von Färsen in die Herde vor der Abkalbung (vs. nach der Abkalbung), einem niedrigeren Tier-LiegeboxenVerhältnis (<95 vs. $\geq 95$ Kühe/100 Boxen), größere Fressplatzbreiten ( $>3,6 \mathrm{~m}$ vs. $<3,6 \mathrm{~m}$ ), größeres Verkehrsflächenangebot $\left(>4,4 \mathrm{~m}^{2} \mathrm{vs} .<4,4 \mathrm{~m}^{2}\right)$, die Anwesenheit einer Kraftfutterstation (vs. keine Kraftfutterstation), einem mittleren TierFressplatz-Verhältnis (105-118 vs. $<105$ und $>118$ Kühe/100 Fressplätze) und mittlere Troglängen pro Kuh $(4,7-6,8 \mathrm{~cm}$ vs. $<4,7 \mathrm{~cm}$ und $>6,8 \mathrm{~cm})$ konnten beobachtet werden $(p<0,20)$. Im Gegensatz dazu wurden keine Assoziationen zwischen den untersuchten Haltungs- und Managementfaktoren und den Prävalenzen von Läsionen und Schwellungen gefunden $(p>0,20)$. Der Benchmarking-Vergleich von Betrieben mit höheren und niedrigeren Tierwohlbewertungen hinsichtlich ausgewählter Haltungs- und Managementfaktoren kann den Studienergebnissen zufolge nützliche Informationen über effektive Möglichkeiten zur Verbesserung des Tierwohls bei Milchkühen liefern.

Zusammenfassend lässt sich feststellen, dass das Tierwohl auf Milchviehbetrieben durch viele verschiedene Haltungs- und Managementfaktoren beeinflusst werden kann. Aufgrund des multidimensionalen Charakters des Tierwohls ist eine pauschale Bewertung von Milchviehbetrieben anhand einzelner Haltungsund Managementfaktoren wie z.B. Bestandsgröße und Bestandsdichte problematisch. Den Erkenntnissen der vorliegenden Dissertation zufolge ist vielmehr eine Betrachtung des Tierwohlniveaus auf Betriebsebene erforderlich, da sich nur so die komplexen Interaktionen von Haltungsumwelt und Managementpraxis annähernd abbilden lassen. Die Ergebnisse der Tierwohlbewertungen mit Hilfe 
des Welfare Quality ${ }^{\circledR}$ Protokolls für Rinder unterscheiden sich sehr deutlich zwischen den Betrieben, so dass von einem erheblichen innerbetrieblichen Potential zur Verbesserung des Tierwohls ausgegangen werden kann. Dabei könnte der im Rahmen des Promotionsvorhabens getestete Benchmarking-Ansatz einen wichtigen Beitrag zur Optimierung der Haltungsumwelt und der Managementpraxis leisten. Zum einen liefert dieses Verfahren wichtige Informationen zu potentiellen Erfolgsfaktoren aus den Bereichen Haltung und Management und zum anderen könnte durch den praxisnahen Vergleich mit anderen Milchviehbetrieben die Motivation zur Investition in erfolgsversprechende Tierwohlverbesserungsmaßnahmen erhöht werden. 


\section{Summary}

The main objective of this Phd-study was to examine the effect of different housing and management factors on the animal welfare level in dairy cattle. Therefore, 85 conventional dairy cattle farms were assessed using multiple measures of the Welfare Quality ${ }^{\circledR}$ assessment protocol for dairy cattle. This is an predominantly animal-based indicator system for assessing the on-farm animal welfare level. Data were recorded from April 2014 to September 2016 by an experienced single assessor in northern Germany. Each farm was visited two times at an interval of six months (summer period and winter period) to avoid seasonal effects on the outcome. The average herd size was $383 \pm 356$ Holstein-Friesian cows (range 45 to 1,629$)$. Only farms with loose housing systems and zero-pasturing were included in the study in order to ensure the comparability of the housing conditions. The dataset was statistically analyzed regarding different housing and management factors (studies I-III).

The objective of the first study was to examine the effect of herd size on animal welfare in dairy cattle farming. Therefore, 80 conventional dairy cattle farms were classified by the number of cows into four herd size classes C1 ( $<100$ cows), C2 (100-299 cows), C3 (300-499 cows) and C4 ( $\geq 500$ cows) and assessed using multiple animal-based measures of the Welfare Quality ${ }^{\circledR}$ assessment protocol for dairy cattle. Data were statistically analyzed using a generalized linear mixed model. None of the farms reached the highest rating "excellent". The majority of the farms were classified as "enhanced" $(30 \%)$ or "acceptable" $(66 \%)$, while at six assessments farms were rated as "not classified" (4\%). Mean trough length per cow, percentage of cows with nasal discharge and vulvar discharge increased with increasing herd size, while displacements per cow and hour decreased with increasing herd size. Percentage of lean cows, percentage of dirty lower legs and duration of the lying down process showed a curvilinear relationship with the number of cows per farm. Herd size did not affect any other indicators of the Welfare Quality ${ }^{\circledR}$ protocol. In conclusion, herd size effects were low and consequently herd size cannot be considered as a feasible indicator of the on-farm animal welfare level. Housing conditions and management practices seem to have a greater impact on animal welfare than the number of dairy cows per farm. 
The objective of the second study was to examine the effect of stocking density on animal welfare in dairy cattle farming. Therefore, 75 conventional dairy cattle farms were assessed using multiple animal-based measures of the Welfare Quality ${ }^{\circledR}$ protocol for dairy cattle. Stocking density groups were classified using tertiles by low (73-95\%), medium (96-103\%) or high (105-133\%) cow-to-stall ratios (CSR); low (67-104\%), medium (105-121\%) or high (122-163\%) cow-to-feeding place ratios (CFR) and high (4.5-7.0 $\left.\mathrm{m}^{2}\right)$, medium (3.7-4.4 $\left.\mathrm{m}^{2}\right)$ or low (2.5-3.6 $\left.\mathrm{m}^{2}\right)$ walking space availability (WSA). Data were statistically analyzed using a generalized linear mixed model. The number of severely lame cows were higher in farms with high (37.7\%), compared to farms with low (22.3\%) to medium (23.0\%) CSR. Percentages of cows with nasal discharge differed between farms with high (19.1\%) and farms with low (25.7\%) CSR. Similarly, most head butts per cow and hour were recorded in farms with low (0.6), compared to farms with medium and high CFR (0.3). Scores of the criterion "positive emotions" were higher in farms with medium (85.1 points) and high (83.9 points), compared to farms with low (74.1 points) CFR. Highest percentages of severely lame cows were observed in farms with medium (31.2\%) to high (33.1\%), while lowest percentages were found in farms with low (18.8\%) WSA. Contrastingly, the highest percentages of cows with mastitis $(23.7 \%)$ were determined in farms with low, compared to medium WSA (17.8\%). No other indicators of the Welfare Quality ${ }^{\circledR}$ protocol were affected by the examined stocking density parameters. In conclusion, findings of the present study did not indicate a consistent relationship between stocking density and animal welfare. Some indicators were better in farms with higher stocking densities, while others were better in farms with lower stocking densities. Therefore, stocking density cannot be considered as a feasible animal welfare indicator. $\mathrm{Pa}$ rameters of stocking density (CSR, CFR, WSA) affect animal welfare of dairy cows in different ways and should therefore be considered simultaneously for optimizing housing and management in dairy cattle farms.

The objective of the third study was to examine the effect of housing and management factors on animal welfare indicators in dairy cows using a benchmarking approach. In total, 63 conventional loose housing dairy cattle farms with zeropasturing were assessed using multiple animal-based measures of the Welfare 
Quality ${ }^{\circledR}$ protocol (WQP) for dairy cattle. Five indicators (lean cows, lesions/swellings, severe lameness, mastitis incidence, and social behavior) were selected, because they reflect diverse aspects of animal welfare. Additionally, housing conditions like barns, cubicles and floors were documented and farmers were interviewed concerning their management routines. Dairy farms were categorized as high welfare groups (HW) and low welfare groups (LW) by calculating upper and lower tertiles for each animal welfare indicator separately. Both groups were compared with regard to provided housing conditions or applied management practices using uni- and multivariable logistic regression analysis. Higher feeding frequencies ( $>1$ vs. $1 \mathrm{x} /$ day), feeding total mixed ration (vs. partly mixed ration), feeding groups (vs. 1 feeding group) and the amount of concentrate feeding ( $>8.5$ vs. $<8.5 \mathrm{~kg} /$ day) were positively associated with lower percentages of very lean cows $(p<0.20)$. Lower prevalences of severely lame cows were related to medium cow-to-stall ratios (95-105 vs. $<95$ and $>105$ cows/100 stalls), higher frequency of claw trimming (>2.5 vs. $<2.5 \mathrm{x} / \mathrm{year}$ ), routine use of footbaths (vs. no routine use), solid flooring (vs. slatted flooring) and rubber mats on the floor (vs. no rubber mats) $(p<0.20)$. Lower numbers of animals with high milk somatic cell counts $(>400,000$ cells $/ \mathrm{ml}$ ) were positively associated with milking in a milking parlor (vs. automatic milking system), lower milking frequency ( 2 vs. $>2 x /$ day) and routine use of antibiotic dry cow therapy (vs. on demand) $(p<0.20)$. Associations between lower levels of agonistic interactions and integration of heifers in the herd before calving (vs. after calving), lower cow-to-stall ratios ( $<95$ vs. $\geq 95$ cows/100 stalls), higher feeding alley widths ( $>3.6 \mathrm{~m}$ vs. $<3.6 \mathrm{~m}$ ), higher walking spaces per cow $\left(>4.4 \mathrm{~m}^{2}\right.$ vs. $<4.4 \mathrm{~m}^{2}$ ), presence of concentrate feeder stations (vs. absence), medium cow-to-feeding place ratios (105-118 vs. $<105$ and $>118$ cows $/ 100$ feeding places) and medium trough length per cow $(4.7-6.8 \mathrm{~cm}$ vs. $<4.7 \mathrm{~cm}$ and $>6.8$ $\mathrm{cm})$ were observed $(p<0.20)$. Contrastingly, no associations between the preselected housing and management factors on the prevalences of lesions and swellings were found $(p>0.20)$. Comparing farms with higher and lower animal welfare performances regarding selected housing and management factors, provide useful information about effective options to improve animal welfare in dairy cattle. 
Summarizing it could be determined, that animal welfare in dairy cattle farms is affected by several housing and management factors. Due to the multidimensional character of animal welfare a sweeping evaluation regarding single housing and management factors such as herd size and stocking density is problematic. Following the findings of the present Phd-study, an on-farm assessment of the animal welfare level is necessary to reflect the complex interactions between housing system and management practices. Results of the animal welfare assessments using the Welfare Quality ${ }^{\circledR}$ protocol widely differ between dairy cattle farms. Consequently, an enormous internal potential for improvements of the animal welfare level could be assumed. The tested benchmarking-approach could contribute to optimize housing conditions and management practices. On the one hand this method delivers relevant information on potential success factors from the fields of housing and management. On the other hand using a practical comparism with other dairy cattle farms might increase the motivation to invest in promising animal welfare improvement activities. 
KAPITEL 1

Einleitung 


\section{Kapitel $1 \quad$ Einleitung}

\subsection{Hintergrund und Relevanz}

In den letzten Jahrzehnten hat sich die Einstellung der Bevölkerung gegenüber der Nutztierhaltung stark gewandelt (Cembalo et al., 2016). Das Interesse am Thema Tierwohl in der Nutztierhaltung ist stetig gewachsen und viele Verbraucher beurteilen die Intensivierung der Tierproduktion zunehmend kritisch (Spooner et al., 2014; Wissenschaftlicher Beirat, 2015; Europäische Kommission, 2016). Die aktuelle Tierwohldebatte befasst sich in erster Linie mit den Produktionsbedingungen in der Schweine- und Geflügelhaltung (Verbeke, 2009; Weinrich et al., 2015; Clark et al., 2016). Hingegen wird die Milchviehbranche von den Verbrauchern bisher noch nicht mit gravierenden Tierwohlproblemen in Verbindung gebracht (Ellis et al., 2009; Ventura et al., 2013). Das positive Image der Milchviehhaltung könnte sich zukünftig jedoch deutlich verschlechtern, da verschiedene Haltungs- und Managementverfahren, wie z.B. ganzjährige Stallhaltung (Schuppli et al., 2014; Cardoso et al., 2016), prophylaktischer Antibiotikaeinsatz (Clark et al., 2016; Wolf et al., 2016) oder die Enthornung von Kälbern (Widmar et al., 2017), den gesellschaftlichen Ansprüchen an die Nutztierhaltung nicht mehr genügen. Vor diesem Hintergrund erscheint es sinnvoll, sich bereits im Vorfeld der zu erwartenden gesellschaftlichen Diskussion pro-aktiv mit Tierwohlproblemen in der Milchviehhaltung zu beschäftigen und die potentiellen Einflüsse von Haltung und Management auf das Tierwohl bei Milchkühen wissenschaftlich zu untersuchen (Barkema et al., 2015; Weary et al., 2017). Auf dieser Basis könnten Risikofaktoren für das Tierwohl identifiziert und konkrete Maßnahmen zur nachhaltigen Verbesserung des Tierwohlniveaus auf Milchviehbetrieben abgeleitet werden. Im Folgenden werden einige aus gesellschaftlicher Sicht bedeutende Problemfelder der Milchviehhaltung vorgestellt:

Für viele Verbraucher sind die im Zuge des Strukturwandels zunehmenden Bestandsgrößen sehr problematisch. Sie lehnen die sogenannte "Massentierhaltung" in großen Tierbeständen ab, da sie diese mit gravierenden Gesundheitsund Verhaltensproblemen verbinden (Prickett et al., 2010; Boogard et al., 2011). Ein direkter Zusammenhang zwischen der Bestandsgröße und dem Tierwohlni- 
veau in Milchviehbetrieben ist bislang jedoch wissenschaftlich nicht nachgewiesen worden. Zwar haben viele Studien die Bestandsgröße als Einflussfaktor untersucht, aber die in der Literatur beschriebenen Effekte sind keinesfalls eindeutig. Einige Studien haben beispielsweise eine positive Korrelation zwischen der Bestandsgröße und Tierwohlindikatoren wie Lahmheit (Alban et al., 1995; de Vries et al., 2014) oder Mastitis (Lievaart et al., 2007; Archer et al., 2013) gefunden. Im Gegensatz dazu wurden auch negative Korrelationen für Lahmheit (Dippel et al., 2009; Chapinal et al., 2013; Solano et al., 2015) oder Mastitis (Olleginni et al., 2001; Simensen et al., 2010) beschrieben. Darüber hinaus haben auch zahlreiche Autoren keinen Zusammenhang zwischen den genannten Tierwohlindikatoren nachweisen können (u.a. Barker et al., 2010; Fabian et al., 2014, Ivemeyer et al., 2011). Bislang wurde der Einfluss der Bestandsgröße jedoch nur als Risikofaktor auf einzelne Tierwohlaspekte untersucht. Einen umfassenderen Vergleich des Tierwohlniveaus zwischen großen und kleinen Betrieben gibt es bislang noch nicht (Robbins et al., 2016). Ziel der ersten Studie war es, Effekte der Bestandsgröße auf das Tierwohlniveau in Milchviehbetrieben zu untersuchen und die Eignung der Bestandsgröße als Tierwohlindikator zu überprüfen.

Neben der Bestandsgröße wird auch der Einfluss der Bestandsdichte auf das Tierwohlniveau von vielen Verbrauchern als ein wichtiges Problemfeld angesehen (Vanhonacker et al., 2008). In Milchviehbetrieben wird die Bestandsdichte üblicherweise hinsichtlich der zur Verfügung stehenden Ressourcen wie z.B. Liegeboxen, Fressplätze oder Verkehrsflächen definiert (Krawczel et al., 2012b). Als Parameter für die Bestandsdichte werden dementsprechend das Tier-Liegeboxen-Verhältnis, das Tier-Fressplatz-Verhältnis und das Platzangebot verwendet (de Vries et al., 2016). Milchviehställe werden als überbelegt klassifiziert, wenn mehr Milchkühe eingestallt sind als Liegeboxen oder Fressplätze zur Verfügung stehen (>100\%). Im Gegensatz dazu gelten Betriebe als unterbelegt, wenn das Verhältnis umgekehrt ist $(<100 \%)$. Viele Studien haben die Effekte einer in der Praxis weit verbreiteten Überbelegung in Milchviehställen auf verschiedene Gesundheits- oder Verhaltensindikatoren untersucht (von Keyserlingk et al., 2012). Beispielsweise fanden Hill et al. (2009) heraus, dass die Liege- und Fresszeiten mit steigendem Tier-Liegeboxen-Verhältnis abnahmen. Zudem wurden in einer kanadischen Studie mehr Vertreibungen am Futterplatz beobachtet, wenn das 
Tier-Fressplatz-Verhältnis eingeschränkt war (Huzzey et al., 2006). Demgegenüber wurden in anderen Untersuchungen keine Effekte einer steigenden Bestandsdichte auf einzelne Tierwohlindikatoren gefunden (Telezhenko et al., 2012; Wang et al., 2016). Die genannten Studien wurden jedoch ausschließlich experimentell durchgeführt und erlauben daher keine Aussagen über die langfristigen Folgen einer Überbelegung in der Praxis (Chebel et al., 2016; de Vries et al., 2016). Ziel der zweiten Studie war es, Effekte der Bestandsdichte auf das Tierwohlniveau in Milchviehbetrieben zu untersuchen und die Eignung der Bestandsdichte als Tierwohlindikator zu überprüfen.

Ein weiterer Aspekt in der aktuellen Tierwohldebatte betrifft den Einfluss der Haltungsumwelt und des Managements auf die Tiere. Haltungsbedingungen (z.B. Fressplatz-, Liegeplatz- und Laufwegegestaltung) und Managementpraxis (z.B. Melkhygiene, Fütterungsfrequenz) sind für Milchkühe von großer Bedeutung, da diese einen Großteil ihres Lebens in Ställen verbringen (EFSA, 2010; Arnott et al., 2016). Der Effekt verschiedener Haltungs- und Managementfaktoren auf einzelne Tierwohlindikatoren wurde in vielen Studien untersucht. Beispielsweise wurde ein Zusammenhang zwischen der Laufganggestaltung und der Prävalenz von Lahmheit in einer österreichischen Studie beobachtet. Das Risiko für Klauenerkrankungen war in Betrieben mit Spaltenboden im Gegensatz zu planbefestigten Böden erhöht (Dippel et al., 2009). Ein anderes Beispiel für den Einfluss der Haltungsumwelt ist die Liegeboxengestaltung. Das Risiko für schwere Integumentschäden ist in Tiefboxen geringer als in Hochboxen (Brenninkmeyer et al., 2013). Darüber hinaus können auch verschiedene Managementpraktiken das Tierwohlniveau beeinflussen. In Betrieben mit einem geringen Zellzahlgehalt wurden während des Melkvorgangs häufiger Handschuhe getragen, als in Betrieben mit einem höheren Zellzahlgehalt (Rodrigues et al., 2005). In den meisten Studien wurde der jeweilige Effekt im Rahmen einer Risikoanalyse nachgewiesen, bei der eine Gruppe mit schlechten Bewertungen in einzelnen Tierwohlindikatoren mit einer größeren Kontrollgruppe verglichen wurde. Die Differenzen zwischen diesen beiden Gruppen waren jedoch möglicherweise nur gering und wichtige Einflussfaktoren bleiben demzufolge unentdeckt. Das Ziel der dritten Studie war es, den Effekt von Haltungs- und Managementfaktoren auf Tierwohlindikatoren bei Milchkühen mit Hilfe eines Benchmarking-Vergleiches zwischen guten und schlechten Betrieben zu untersuchen. 


\subsection{Ziele der Dissertation}

Das generelle Ziel der vorliegenden Doktorarbeit war es, den Einfluss verschiedener Haltungs- und Managementfaktoren auf das Tierwohlniveau in der Milchviehhaltung zu untersuchen. Dabei sollten insbesondere der Zusammenhang zwischen den im Fokus der gesellschaftlichen Diskussion stehenden Faktoren "Bestandsgröße“ und „Bestandsdichte“ und dem Tierwohlniveau auf Betriebsebene betrachtet werden. Darüber hinaus wurde im Rahmen des Promotionsvorhabens ein neuartiger Benchmarking-Ansatz angewendet, um Risikofaktoren für das Tierwohlniveau von Milchkühen ableiten zu können. Im Rahmen des Promotionsvorhabens wurden insgesamt 85 konventionelle Milchviehbetriebe mit Liegeboxenlaufställen und ohne Weidezugang zweimalig im Abstand von 6 Monaten mit Hilfe des Welfare Quality ${ }^{\circledR}$ Protokolls für Rinder hinsichtlich ihres Tierwohlniveaus bewertet. Der Tierwohlindikatorendatensatz und die zusätzlich erhobenen Haltungs- und Managementdaten wurden im Anschluss bezüglich der folgenden drei Fragestellungen ausgewertet:

Besteht ein Zusammenhang zwischen der Bestandsgröße und dem Tierwohlniveau in Milchviehbetrieben? Die Hypothese lautet: Bestandsgröße ist kein geeigneter Indikator für das Tierwohlniveau (Kapitel 3).

Besteht ein Zusammenhang zwischen der Bestandsdichte und dem Tierwohlniveau in Milchviehbetrieben? Die Hypothese lautet: Bestandsdichte ist kein geeigneter Indikator für das Tierwohlniveau (Kapitel 4).

> Unterscheiden sich Betriebe mit guten und schlechten Ergebnissen in einzelnen Tierwohlindikatoren hinsichtlich ihrer Haltungsumwelt und ihres Managements? Die Hypothese lautet: Risikofaktoren für das Tierwohl lassen sich anhand eines Benchmarking-Ansatzes ableiten (Kapitel 5).

\subsection{Aufbau der Dissertation}

Die vorliegende Doktorarbeit besteht aus 7 Kapiteln und verschiedenen Anhängen. Eine generelle Übersicht zur Struktur der Milchviehhaltung in Deutschland und potentiellen Tierwohlproblemen bei Milchkühen findet sich in der Literaturübersicht in Kapitel 2. Darüber hinaus werden darin Methoden zur Erhebung und 
Beurteilung von Tierwohlindikatoren auf Betriebsebene erläutert. Danach folgen die drei Manuskripte zum Einfluss der Bestandsgröße auf das Tierwohl bei Milchkühen (Kapitel 3), Einfluss der Bestandsdichte auf das Tierwohl bei Milchkühen (Kapitel 4) und Einfluss von Haltungs- und Managementfaktoren auf das Tierwohl bei Milchkühen (Kapitel 5). Daraufhin werden die Ergebnisse der drei Manuskripte gemeinsam diskutiert (Kapitel 6) und schließlich allgemeine Schlussfolgerungen gezogen (Kapitel 7). Im Anhang finden sich ergänzende Tabellen, Formulare zur Erhebung des Welfare Quality ${ }^{\circledR}$ Protokolls, der Haltungsumwelt im Stall, Fragebögen zur Managementpraxis sowie der Lebenslauf und die Publikationsliste des Autors.

\subsection{Literaturverzeichnis}

Alban, L. 1995. Lameness in Danish dairy cows: frequency and possible risk factors. Prev. Vet. Med. 22:213-225. https://doi.org/10.1016/0167-5877 (94)00411-B.

Archer, S.C., F. McCoy, W. Wapenaar, and M.J. Green. 2013. Association of season and herd size with somatic cell count for cows in Irish, English, and Welsh dairy herds. Vet. J. 196:515-521. http://dx.doi.org/10.1016/j.tvil. 2012.12.004.

Arnott, G., C.P. Ferris, and N.E. O'Connell. 2016. Review: welfare of dairy cows in continuously housed and pasture-based production systems. Animal. 11:261-273. https://doi.org/10.1017/S1751731116001336.

Barkema, H.W., M.A.G. von Keyserlingk, J.P. Kastelic, T.J.G.M. Lam, C. Luby, J.-P. Roy, S.J. LeBlanc, G.P. Keefe, and D.F. Kelton. 2015. Invited review: Changes in the dairy industry affecting dairy cattle health and welfare. J. Dairy Sci. 98:7426-7445. https://doi.org/10.3168/jds.2015-9377.

Barker, Z.E., K.A. Leach, H.R. Whay, N.J. Bell, and D.C.J. Main. 2010. Assessment of lameness prevalence and associated risk factors in dairy herds in England and Wales. J. Dairy Sci. 93: 932-941. https://doi.org/ 10.3168/ids.2009-2309.

Boogard, B.K., B. Bock, S.J. Oosting, J.S.C. Wiskerke, and A.J. van der Zijpp. 2011. Social acceptance of dairy farming: The ambivalence between the two faces of modernity. J. Agric. Environ. Ethics. 24:259-282. http://dx. doi.org/10.1007/s10806-010-9256-4

Brenninkmeyer, C., S. Dippel, J. Brinkmann, S. March, C. Winckler, and U. Knierim, 2013. Hock lesion epidemiology in cubicle housed dairy cows 
across two breeds, farming systems and countries. Prev. Vet. Med. 109:236-245. https://doi.org/10.1016/i.prevetmed.2012.10.014.

Cardoso, C.S., M.J. Hötzel, D.M. Weary, J.A. Robbins, and M.A.G. von Keyserlingk. 2016. Imagining the ideal dairy farm. J. Dairy Sci. 99:1663-1671. http://dx.doi.org/10.3168/jds.2015-9925.

Cembalo, L., F. Caracciolo, A. Lombard, T. Del Giudice, K.G. Grunert, and G. Cicia. 2016. Determinants of individual attitudes toward animal welfarefriendly food products. J. Agric. Environ. Ethics. 29:237-254. https://doi .org/10.1007/s10806-015-9598-z.

Chapinal, N., A.K. Barrientos, M.A.G. von Keyserlingk, E. Galo, and D.M. Weary. 2013. Herd-level risk factors for lameness in freestall farms in the northeastern United States and California. J. Dairy Sci. 96:318-328. https:// doi.org/10.3168/jds.2012-5940.

Chebel, R.C., P.R.B. Silva, M.I. Endres, M.A. Ballou, and K.L. Luchterland. 2016. Social stressors and their effects on immunity and health of periparturient dairy cows. J. Dairy Sci. 99:3217-3228. https://doi.org/10.3168/jds.201510369.

Clark, B., G.B. Stewart, L.A. Panzone, I. Kyriazakis, and L.J. Frewer. 2016. A systematic review of public attitudes, perceptions and behaviours towards production diseases associated with farm animal welfare. J. Agric. Environ. Ethics. 29: 455-478. https://doi.org/10.1007/s10806-016-9615-x.

De Vries, A., H. Dechassa, and H. Hogeveen. 2016. Economic evaluation of stall stocking density of lactating dairy cows. J. Dairy Sci. 99:3448-3857. https://doi.org/10.3168/jds.2015-10556.

De Vries, M., E.A.M. Bokkers, G. van Schaik, B. Engel, T. Dijkstra, and J.M. de Boer. 2014. Exploring the value of routinely collected herd data for estimating dairy cattle welfare. J. Dairy Sci. 97:715-730. http://dx.doi.org/ 10.3168/jds.2013-6585.

De Vries, M., E.A.M. Bokkers, G. van Schaik, B. Engel, T. Dijkstra, and I.J.M. de Boer. 2016. Improving the time efficiency of identifying dairy herds with poorer welfare in a population. J. Dairy Sci. 99:8282-8296. http://dx.doi. org/10.3168/jds.2015-9979.

Dippel, S., M. Dolezal, C. Brenninkmeyer, J. Brinkmann, S. March, U. Knierim, and C. Winckler. 2009. Risk factors for lameness in cubicle housed Austrian Simmental dairy cows. Prev. Vet. Med. 90:102-112. http://dx.doi .org/ 10.1016/i.prevetmed.2009.03.014.

Doherr, M.G., M. Roesch, W. Schaeren, M. Schallibaum, and J.W. Blum. 2007. Risk factors associated with subclinical mastitis in dairy cows on Swiss 
organic and conventional production system farms. Vet. Med. 52:487-495. https://doi.org/10.17221/2060-VETMED.

EFSA. 2010. Animal welfare risk assessment guidelines on housing and management. Technical report (EFSA-Q-2009-00844). Wageningen UR Livestock Research. http://www.efsa.europa.eu/en/supporting/pub/en-87. (Accessed 04. November 2017).

Ellis, K.A., K. Billington, B. McNeil, and D.E.F. McKeegan. 2009. Public opinion on UK milk marketing and dairy cow welfare. Anim. Welf. 18:267-282. ISSN : $0962-7286$.

European Commission. 2016. Attitudes of Europeans towards animal welfare. Special Eurobarometer442. http://ec.europa.eu/COMMFrontOffice/publicopinion/index.cfm/Survey/getSurveyDetail/instruments/SPECIAL/surveyKy/2096 (Accessed 05. September 2017).

Fabian, J., R.A. Laven, and H.R. Whay. 2014. The prevalence of lameness on New Zealand dairy farms: A comparism of farmer estimate and locomotion scoring. The Vet. J. 201:31-38. http://dx.doi.org/10.1016/..tvil.2014.05. 011.

Hill, C.T., P.D. Krawczel, H.M. Mann, C.S. Ballard, R.C. Hovey, W.A. Falls, and R.J. Grant. 2009. Effect of stocking density on the short-term behavioural responses of dairy cows. Appl. Anim. Beh. Sci. 117:144-149. https://doi. org/10.1016/j.applanim.2008.12.012.

Huzzey, J.M., T.J. DeVries, P. Valois, and M.A.G. von Keyserlingk. 2006. Stocking density and feed barrier design affect the feeding and social behavior of dairy cattle. J. Dairy Sci. 89, 126-133. https://doi.org/10.3168/jds. S0022-0302(06)72075-6.

Ivemeyer, S., U. Knierim, and S. Waiblinger. 2011. Effect of human-animal relationship and management on udder health in Swiss dairy herds. J. Dairy Sci. 94: 5890-5902. https://doi.org/10.3168/jds.2010-4048.

Krawczel, P.D., L.B. Klaiber, R.E. Butzler, L.M. Klaiber, H.M. Dann, C.S. Mooney, and R.J. Grant. 2012b. Short-term increases in stocking density affect the lying and social behavior, but not the productivity, of lactating Holstein dairy cows. J. Dairy Sci. 95:4298-4308. https://doi.org/10.3168/jds.20114687.

Lievaart, J.J., H.W. Barkema, W.D.J. Kremer, J. van den Broek, J.H.M. Verheijden, and J.A.P. Heesterbeek. 2007. Effect of herd characteristics, management practices, and season on different categories of the herd somatic cell count. J. Dairy Sci. 90:4137-4144. https://doi.org/10.3168/jds. 2006-847. 
Oleggini, G.H., L.O. Ely, and J.W. Smith. 2001. Effect of region and herd size on dairy herd performance parameters. J. Dairy Sci. 84:1044-1050. https:// doi.org/10.3168/jds.S0022 -0302(01)74564-X.

Prickett, R.W., F.B. Norwood, and J.L. Lusk. 2010. Consumer preferences for farm animal welfare: results from a telephone survey of US households. Anim. Welf. 19: 335-347. ISSN 0962-7286.

Robbins, J.A., M. von Keyserlingk, D. Fraser, and D.M. Weary. 2016. Invited review: Farm size and animal welfare. J. Anim. Sci. 94:5439-5455. https:// doi.org/10.2527/jas.2016-0805.

Rodrigues, A.C.O., D.Z. Caraviello, and P.L. Ruegg. 2005. Management of Wisconsin dairy herds enrolled in milk quality teams. J. Dairy Sci. 88:26602671. https://doi.org/ 10.3168/jds.S0022-0302(05)72943-X.

Schuppli, C.A., M.A.G. von Keyserlingk, and D.M. Weary. 2014. Access to pasture for dairy cows: responses from an online engagement. J. Anim. Sci. 92:5185-5192. https://doi.org/10.2527/jas2014-7725.

Simensen, E., O. Osteras, K.E. Boe, C. Kielland, L.E. Ruud, and G. Naess. 2010. Housing system and herd size interactions in Norwegian dairy herds; associations with performance and disease incidence. Acta. Vet. Scand. 52:14. https://doi.org/10.1186/1751-0147-52-14.

Solano, L., H. W. Barkema, E. A. Pajor, S. Mason, S. J. LeBlanc, J. C. Zaffino Heyerhoff, C. G. R. Nash, D. B. Haley, E. Vasseur, D. Pellerin, J. Rushen, A. M. de Passillé, and K. Orsel. 2015. Prevalence of lameness and associated risk factors in Canadian Holstein-Friesian cows housed in freestall barns. J. Dairy Sci. 98:6978-6991. https://doi.org/10.3168/jds.2015-9652.

Spooner, J.M., C.A. Schuppli, and D. Fraser. 2014. Attitudes of Canadian citizens toward animal welfare: A qualitative study. Livest. Sci. 163:150-158. https://doi.org/10.1016/.livsci.2014.02.011.

Telezhenko, E., M.A.G. von Keyserlingk, A. Talebi, and D.M. Weary. 2012. Effect of pen size, group size, and stocking density on activity in freestall-housed dairy cows. J. Dairy Sci. 95:3064-3069. https://doi.org/10.3168/jds.20114953.

Vanhonacker, F., W. Verbeke, E. Van Poucke, and F.A.M. Tuyttens. 2008. Do citizens and farmers interpret the concept of farm animal welfare differently? Livest. Sci. 116:126-136. https://doi.org/10.1016/j.livsci.2007. $\underline{09.017 .}$

Ventura, B.A., M.A.G. von Keyserlingk, C.A. Schuppli, and D.M. Weary. 2013. Views on contentious practices in dairy farming: The case of early cow- 
calf separation. J. Dairy Sci. 96:6105-6116. http://dx.doi.org/10.3168/jds. 2012-6040.

Verbeke, W. 2009. Stakeholder, citizen and consumer interests in farm animal welfare. Anim. Welf. 18:325-333. ISSN 0962-7286.

Von Keyserlingk, M.A.G., A. Barrientos, K. Ito, E. Galo and D.M. Weary. 2012. Benchmarking cow comfort on North American freestall dairies: Lameness, leg injuries, lying time, facility design, and management for high-producing Holstein dairy cows. J. Dairy Sci. 95, 7399-7408. https:// doi.org/ 10.3168/ jds.2012-5807.

Wang, F.X., D.F. Shao, S.L. Li, Y.J. Wang, A. Azarfar, and Z.J. Cao. 2016. Effects of stocking density on behavior, productivity, and comfort indices of lactating dairy cows. J. Dairy Sci. 99:3709-3717. https://doi.org/10.3168/ ids.2015-10098.

Weary, D.M., and M.A.G. von Keyserlingk. 2017. Public concerns about dairycom welfare: how should the industry respond? Anim. Prod. Sci. 57:12011209. http://dx.doi.org/10.1071/AN16680.

Weinrich, R., S. Kühl, A. Franz, and A. Spiller. 2015. Consumer Preferences for High Welfare Meat in Germany: Self-service Counter or Service Counter? Int. J. Food Syst. Dynam. 6:32-49. https://doi.org/10.18461/ijfsd.v6i1 .614.

Welfare Quality. 2012. Welfare Quality ${ }^{\circledR}$ Assessment protocol for cattle. Welfare Quality ${ }^{\circledR}$ Consortium, Lelystad, Netherlands. www.welfarequalitynetwork. net/network/45848/7/0/40 (Accessed 21. August 2017).

Widmar, N.O., C.J. Morgan, C.A. Wolf, E.A. Yeager, S.R. Dominick, and C.C. Croney. 2017. US resident perceptions of dairy cattle management practices. Agric. Sci. 8:645-656. https://doi.org/10.4236/as.2017.87049.

Wissenschaftlicher Beirat Agrarpolitik beim BMEL (WBA). 2015. Wege zu einer gesellschaftlich akzeptierten Nutztierhaltung. Gutachten. Berlin.

Wolf, C.A., G.T. Tonsor, M.G.S. McKendree, D.U. Thomson, and J.C. Swanson. 2016. Public and farmer perceptions of dairy cattle welfare in the United States. J. Dairy Sci. 99:5892-5903. http://dx.doi.org/10.3168/jds.201510619. 


\section{KAPITEL 2}

Literaturübersicht 


\section{Kapitel 2 Literaturübersicht}

\subsection{Struktur der Milchviehhaltung in Deutschland}

Die Milchviehhaltung besitzt in der deutschen Agrarwirtschaft einen hohen Stellenwert. Die Erzeugung von Milch und Milchprodukten trug im Jahre 2012 mit 22,1\% zum Umsatz der Ernährungswirtschaft bei (Nier et al., 2013). Im Jahr 2016 wurden in Deutschland etwa 32,7 Millionen Tonnen Milch erzeugt. Im europäischen Vergleich liegt die deutsche Milchwirtschaft damit vor Frankreich und Großbritannien an der Spitze der Erzeuger (Wissenschaftlicher Beirat, 2015). Durch die Einführung der europäischen Quotenregelung im Jahr 1984 wurde die Milchproduktion gedrosselt, um eine sich abzeichende Überschwemmung der Milchmärkte zu verhindern (Nier et al., 2013). Aus diesem Grund blieben die produzierten Milchmengen in Europa über einen längeren Zeitraum hinweg konstant. Seit der Ankündigung des Quotenendes für das Frühjahr 2015 hat die erzeugte Milchmenge in Deutschland jedoch wieder leicht zugenommen (Wissenschaftlicher Beirat, 2015).

Der Selbstversorgungsgrad mit Milch und Milchprodukten liegt in allen relevanten Produktkategorien (z.B. Trinkmilch, Butter, Joghurt) oberhalb von 100\%. Demzufolge wird in Deutschland mehr Milch produziert, als von der eigenen Bevölkerung verzehrt werden kann. Die deutsche Milchwirtschaft exportiert pro Jahr Produkte im Wert von etwa 9 Milliarden Euro, während nur Waren im Wert von etwa 6 Milliarden importiert werden. Der Exportwert nimmt seit einigen Jahren tendenziell zu und die Molkereibranche agiert zunehmend international. Deutschland beliefert dabei vor allem Länder innerhalb des EU-Binnenmarktes, wie z.B. Niederlande, Italien und Frankreich. Darüber hinaus werden auf dem Weltmarkt auch beträchtliche Mengen an Milchpulver nach China oder Milchprodukte nach Russland exportiert (Ermann et al., 2017; Lindena et al., 2017). Der internationale Milchmarkt ist durch stark volatile Preise gekennzeichnet, die sich maßgeblich auf die nationalen Erzeugerpreise auswirken. Der Milchrohstoffwert in Deutschland zeigte dementsprechend in den letzten 10 Jahren enorme Schwankungen von etwa 20 bis $50 € / 100 \mathrm{~kg}$ Milch. Diese großen Preisschwankungen führen vielfach zu Liquiditätsengpässen und setzen die Milchproduzenten damit finanziell unter Druck (Wissenschaftlicher Beirat, 2015; Ermann et al., 2017). 
In den letzten Jahrzehnten war die Milchproduktion einem stetigen Strukturwandel unterworfen, der sich durch das Auslaufen der Milchquote und die damit verbundenen Preisschwankungen weiter beschleunigen könnte (Wissenschaftlicher Beirat, 2015). Seit 2007 ist die Anzahl an milchviehhaltenden Betrieben in Deutschland um ein Drittel von 101.202 auf 69.053 Betriebe gesunken (vgl. Tabelle 2.1). Dabei zeigte sich, dass der Anteil an Betrieben mit kleineren Betriebskategorien unterhalb von 100 Kühen abgenommen, während der Anteil an größeren Betriebskategorien oberhalb von 100 Kühen z.T. deutlich zugenommen hat. Insbesondere die Betriebsgrößenkategorie 100-199 Kühe hat überproportional an Bedeutung gewonnen. Kleinere Zuwächse konnten jedoch auch für Betriebe mit 200-499 und oberhalb von 500 Kühen festgestellt werden (Destatis, 2008; 2011; 2014; 2017).

Table 2.1: Darstellung der Betriebsentwicklung in Deutschland von 2007 bis 2016. Anzahl Betriebe pro Bestandsgrößenkategorie (Quelle: Destatis, 2008, 2011, 2014, 2017).

\begin{tabular}{ccccc}
\hline Betriebsgröße & $\mathbf{2 0 0 7}$ & $\mathbf{2 0 1 0}$ & $\mathbf{2 0 1 3}$ & $\mathbf{2 0 1 6}$ \\
\hline 1-20 Kühe & 35.810 & 28.117 & 22.500 & 17.847 \\
20-49 Kühe & 41.185 & 34.982 & 28.400 & 23.108 \\
50-99 Kühe & 19.014 & 19.744 & 18.900 & 17.670 \\
100-199 Kühe & 3.660 & 5.211 & 7.000 & 7.742 \\
200-499 Kühe & 1.186 & 1.319 & 1.700 & 2.149 \\
$>500$ Kühe & 347 & 390 & 500 & 538 \\
\hline Gesamt & 101.202 & 89.763 & 79.000 & 69.054 \\
\hline
\end{tabular}

Der Bedeutungsverlust der kleineren Milchviehbetriebe für die deutsche Milchproduktion lässt sich anhand der gehaltenen Milchkühe je Betriebskategorie erkennen (vgl. Abbildung 2.1). Die Anzahl an Milchkühen in Beständen <50 Kühen hat in den Jahren 2007 bis 2016 abgenommen. Insbesondere in der BetriebsgröBenkategorie 20-49 Kühe war eine deutliche Reduktion von etwa 1.300.000 Kühen im Jahr 2007 auf knapp 750.000 Kühen im Jahr 2016 zu verzeichnen. Die Anzahl gehaltener Milchkühe blieb in der mittleren Betriebsgrößenkategorie in diesem Zeitraum nahezu unverändert. Die größeren Betriebe oberhalb von 100 Kühen stockten ihre Bestände hingegen in den letzten Jahren kontinuierlich auf. 


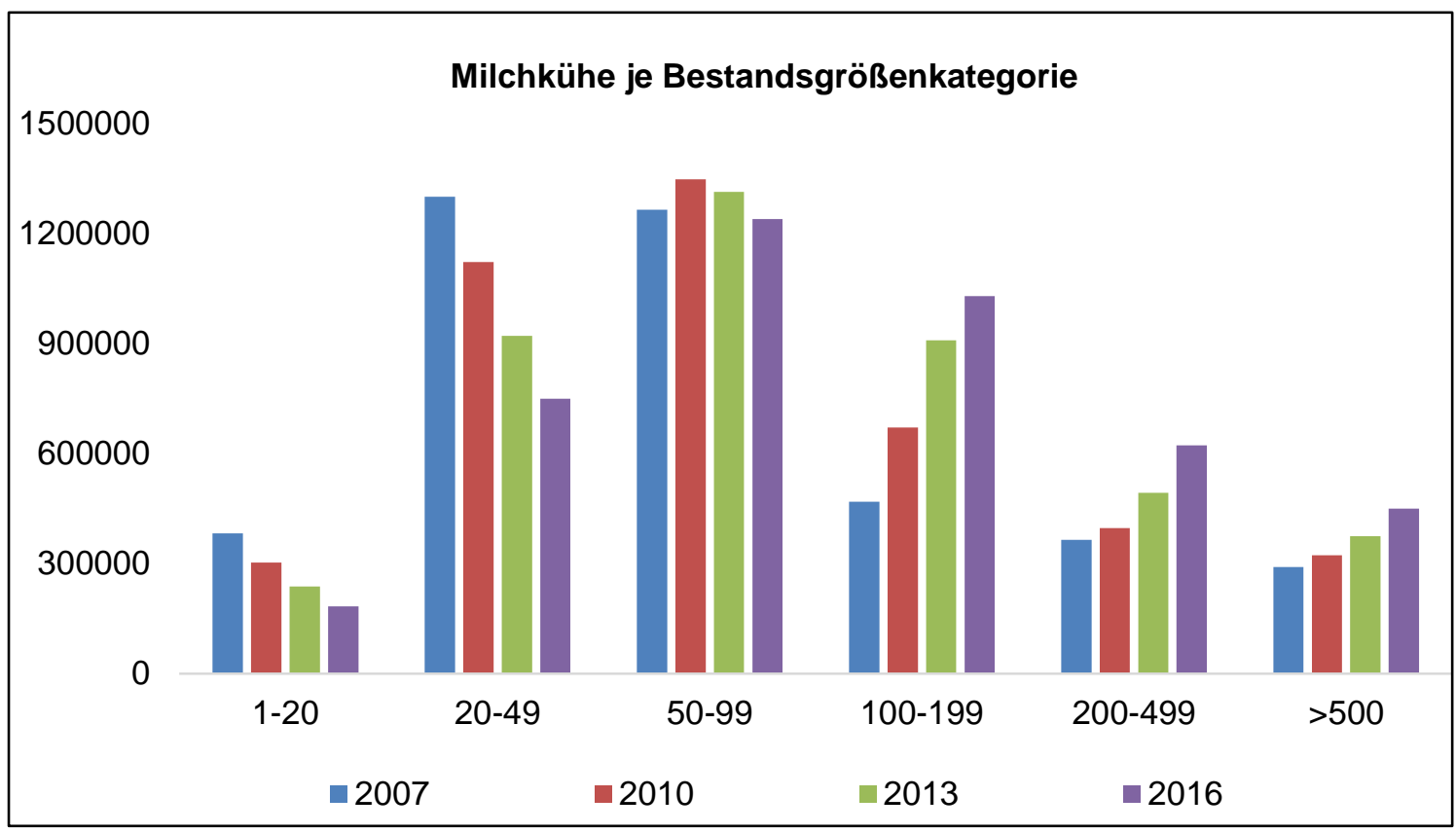

Figure 2.1: Darstellung der Bestandsgrößenentwicklung in Deutschland von 2007 bis 2016. Anzahl Milchkühe pro Bestandsgrößenkategorie (Quelle: Destatis, verschiedene Jahrgänge).

Dementsprechend ist auch die durchschnittliche Bestandsgröße pro Betrieb kontinuierlich angestiegen. Im Zeitraum von 2007 bis 2015 erhöhte sich die mittlere Anzahl an Milchkühen pro Betrieb von 41 auf 59 Tiere (ADR, 2008; 2016). Dabei zeigen sich jedoch zwischen den Bundesländern deutliche Unterschiede hinsichtlich der Bestandsgrößen in den Milchviehbetrieben (Destatis, 2017). In den neuen Bundesländern sind Bestandsgrößen historisch bedingt sehr viel größer als in den alten Bundesländern. In den landwirtschaftlichen Produktionsgenossenschaften (LPG) wurden schon in der damaligen DDR Herden oberhalb von 1000 Tieren gemolken. Einige dieser Milchviehställe sind auch heute noch in Betrieb und tragen somit zu deutlich höheren Bestandsgrößen v.a. in Sachsen-Anhalt ( $\varnothing 206$ Kühe), Mecklenburg-Vorpommern ( $\varnothing 224$ Kühe) und Brandenburg (Ø 226 Kühe) im Jahr 2016 bei (Lindena et al., 2017).

Die Haltungssysteme für Milchkühe unterscheiden sich regional deutlich voneinander. Die Haltung von Milchkühen in Anbindeställen ist insbesondere in Regionen mit kleinbetrieblichen Strukturen wie Bayern und Baden-Württemberg weit verbreitet. Zum Zeitpunkt der letzten Landwirtschaftszählung im Jahr 2010 hatten noch etwa 54\% der Betriebe einen Anbindestall. Durch die relativ kleinen Bestandsgrößen wurden in diesen allerdings nur etwa 27\% der laktierenden Milchkühe gehalten (Destatis, 2011). Die Haltung von Milchkühen in Anbindehaltung 
ist aufgrund der Fixierung über einen längeren Zeitraum aus Tierschutzgründen problematisch. Laufställe mit Liegeboxen oder Stroheinstreu sind vor diesem Hintergrund besser geeignet, da die Tiere ihre natürlichen Verhaltensmuster leichter ausüben können (Wissenschaftlicher Beirat, 2015). Der Anteil an Betrieben mit Weidehaltung hat in den letzten Jahrzehnten deutlich abgenommen. Bedingt durch die zunehmenden Bestandsgrößen und damit einhergehenden arbeitswirtschaftlichen Herausforderungen erhielten im Jahr 2010 nur etwa 42\% der Milchkühe Weidezugang (Destatis, 2011). Der Anteil an Betrieben mit Weidehaltung dürfte seitdem aufgrund des fortschreitenden Strukturwandels nicht zugenommen haben (Wissenschaftlicher Beirat, 2015).

Innerhalb Deutschlands lässt sich eine starke räumliche Konzentration der Milcherzeugung erkennen. Die meisten Milchkühe je 100 ha Landfläche finden sich in Süddeutschland (Bayern, Baden-Württemberg) und in Nordwestdeutschland (Nordrhein-Westfalen, Niedersachsen, Schleswig-Holstein). Diese Regionen sind gekennzeichnet durch einen hohen Grünlandteil, durch den sich Milch kostengünstig erzeugen lässt (vgl. Abbildung 2.2). Die höchsten Zuwächse in der Bestandsgröße wurden in den letzten Jahren entlang der Küstengebiete und Bayern verzeichnet und der Trend zur Verlagerung der Milchproduktion in die genannten Gunststandorte setzt sich somit kontinuierlich fort (Nier et al., 2013).

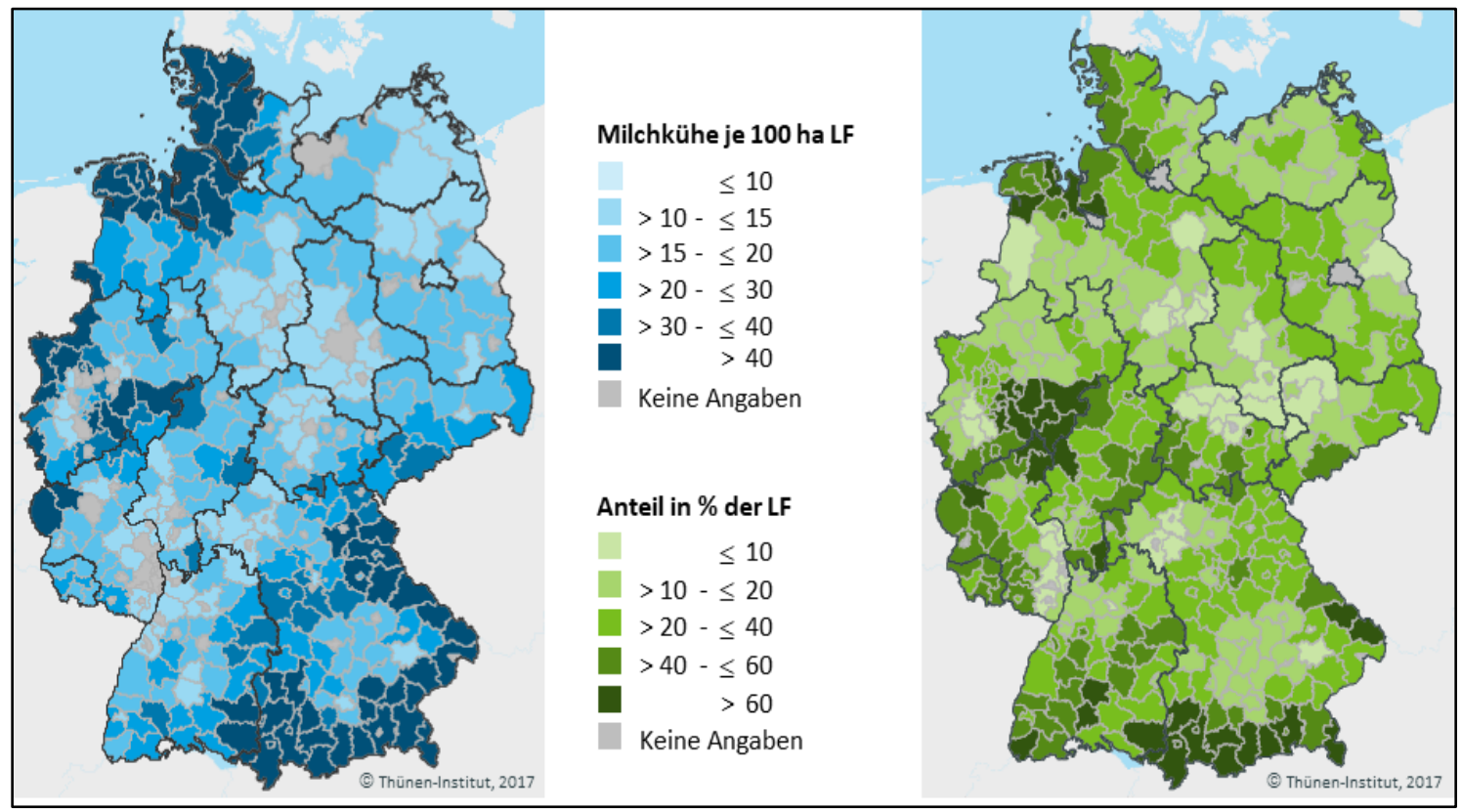

Figure 2.2: Regionale Konzentration von Milchviehhaltung (2016) und Grünlandanteil (2010) in Deutschland (Quelle: Lindena et al., 2017). 
In Süddeutschland werden in erster Linie Zweinutzungsrassen wie Fleckvieh und Braunvieh gehalten, die durch eine niedrigere Milchleistung und einen höheren Fleischanteil als klassische Milchrassen gekennzeichnet sind. Der Anteil an Doppelnutzungsrassen beträgt aktuell etwa $27 \%$. Eine größere Bedeutung für die Milchproduktion besitzt die Holstein Friesian Kuh. Diese ist in den Ausprägungen Schwarzbunt und Rotbunt in den meisten anderen Bundesländern prozentual am häufigsten anzutreffen und insgesamt zu etwa $54 \%$ in der deutschen Milchviehpopulation vertreten (Lindena et al., 2017). Schwarzbunte Holstein Kühe gaben im Jahr 2016 im Mittel 9.307 kg Milch, während die Werte für Fleckvieh $(7.153 \mathrm{~kg}$ Milch) und Braunvieh (7.400 kg Milch) deutlich darunter lagen (VIT, 2016).

Generell setzt sich der Trend zu steigenden Milchleistungen fort. In Abbildung 2.3 ist die durchschnittliche Milchleistung in Deutschland zwischen 1991 und 2013 dargestellt. Während die Kühe zu Beginn der 1990er Jahre noch knapp 5.000 kg Milch lieferten, stieg die Milchleistung in den Folgejahren stetig an und erreichte im Jahr 2007 bereits ein Niveau von $7.000 \mathrm{~kg}$. Seitdem hat sich der Anstieg der Milchleistung etwas abgeschwächt, wobei die Zunahmen pro Jahr immer noch beträchtlich sind (BMEL, 2017). Als Ursachen für die steigenden Milchleistungen gelten verbesserte Haltungsbedingungen, optimiertes Fütterungsmanagement und v.a. züchterischer Fortschritt (Lucy, 2001).

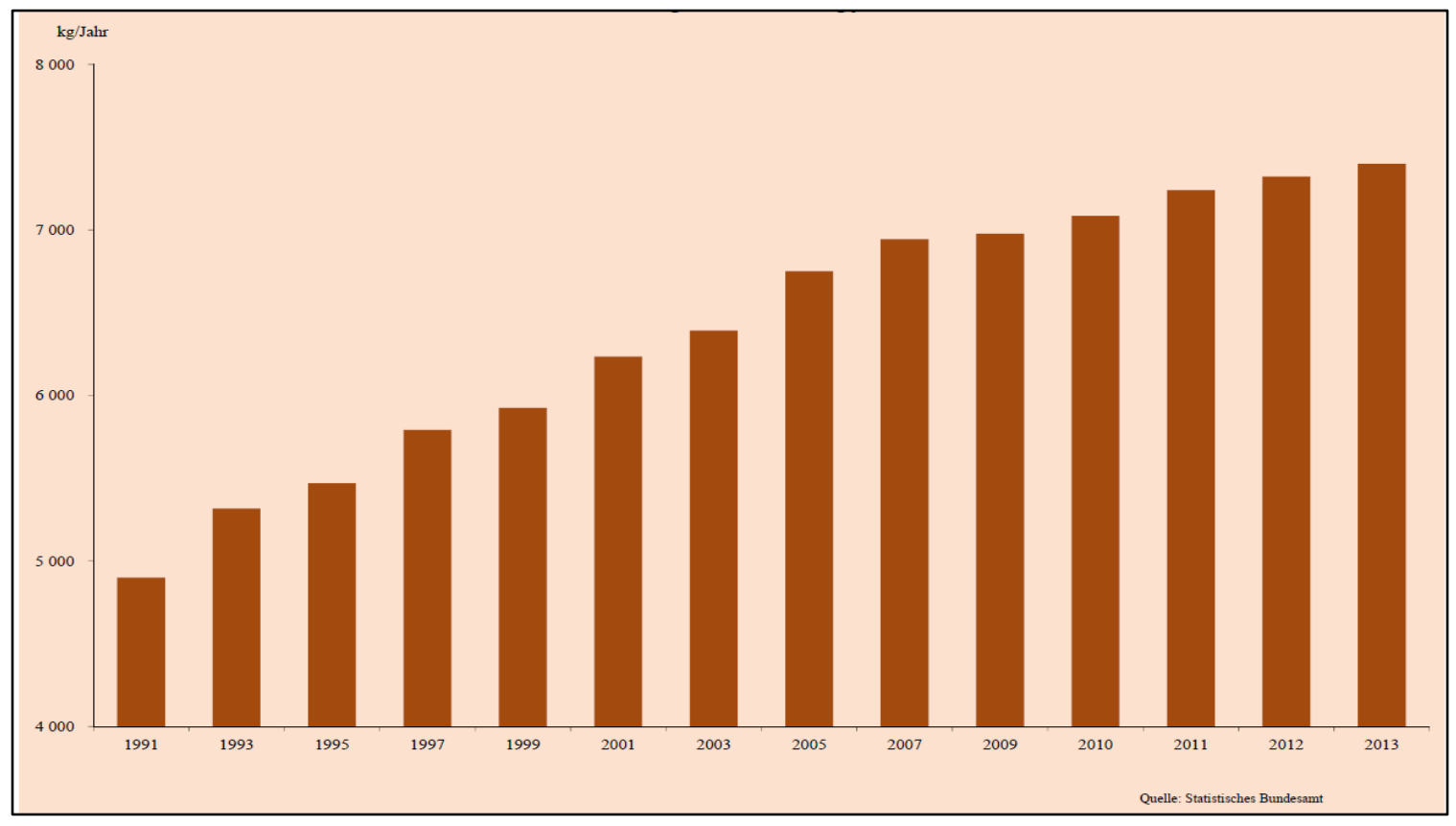

Figure 2.3: Entwicklung der durchschnittlichen Milchleistung (kg) pro Kuh und Jahr im Zeitraum von 1991 bis 2013 (Quelle: BMEL, 2017). 


\subsection{Tierwohlprobleme in der Milchviehhaltung}

\section{Begriffsdefinition}

Der Begriff „Tierwohl“ wird in der vorliegenden Arbeit als Synonym für den in der englischen Literatur gebräuchlichen Begriff „animal welfare“ verwendet. Diese Übersetzung umfasst die wesentlichen Aspekte der ursprünglichen Bedeutung von „animal welfare“ und hat im deutschsprachigen Raum die weiteste Verbreitung gefunden. Der Definition des britischen Farm Animal Welfare Council zufolge beinhaltet "animal welfare" sowohl den physischen (fitness), als auch den psychischen (well-being) Zustand der Tiere (FAWC, 1993). Zur Sicherstellung eines hohen Tierwohlniveaus sind demzufolge nicht nur die Abwesenheit von körperlichen und seelischen Leiden, sondern auch die Erfahrung positiver Emotionen notwendig (Miele et al., 2011). Während der englische Begriff „animal welfare" körperliche und seelische Aspekte vereint, stimmte die ursprüngliche Übersetzung „Wohlbefinden“ nicht mit dem eigentlichen Wortsinn überein (Knierim, 2002; Broom und Fraser, 2007). „Wohlbefinden“ entspricht eher dem hierarchisch untergeordneten „well-being“ und umfasst somit nur einen Teilbereich von „animal welfare“ (FAWC, 1993; Knierim, 1998; Knierim, 2002). Der Begriff „Tierwohl" hingegen beinhaltet körperliche und seelische Aspekte und kommt damit der Definition von „animal welfare“ nahe (Wissenschaftlicher Beirat, 2015).

\section{Tierwohlprobleme}

Zu den bedeutendsten Tierwohlproblemen in der Milchviehhaltung zählen u.a. Eutererkrankungen, Klauenerkrankungen und Stoffwechselstörungen (Schrader, 2009; von Keyserlingk et al., 2009; Wissenschaftlicher Beirat, 2015). Diese Gesundheitsstörungen sind für die meisten unfreiwilligen Abgänge in Milchviehherden verantwortlich. Lediglich durch Unfruchtbarkeit (18,5\%) verlassen mehr Milchkühe den Betrieb als durch Eutererkrankungen (15,1\%), Klauenerkrankungen (13,0\%) oder Stoffwechselstörungen (5,2\%) (VIT, 2016). Ein Ausscheiden aus dem Betrieb aufgrund von Unfruchtbarkeit wird jedoch nicht zu den Tierwohlproblemen gezählt, da es in der Regel aus ökonomischen Gründen erfolgt. Neben den genannten Einschränkungen der Tiergesundheit, können auch Einschränkungen des Tierverhaltens zu Tierwohlproblemen führen (Schrader, 2009; Ventura et al., 2015). Im folgenden Abschnitt werden die relevantesten Tierwohlprobleme in der Milchviehhaltung kurz skizziert: 


\section{Eutererkrankungen}

Entzündungen des Euters verursachen hohe ökonomische Verluste für den Landwirt und beeinträchtigen das Wohlergehen der Tiere (Koivula, 2005). Mastitiden treten in Milchviehbetrieben häufig auf, wobei es große Variationen zwischen den Betrieben gibt. Untersuchungen in Kanada haben z.B. eine mittlere Mastitisinzidenz von 23,0 pro 100 Kuhjahren nachgewiesen (Olde Riekerink et al., 2008). Euterentzündungen können sowohl in klinischer Form, als auch subklinisch auftreten (Bradley, 2002). Klinische Euterentzündungen sind mit äußerlich sichtbaren Symptomen wie Euterschwellungen, Veränderung der Milchkonsistenz und Schmerzen verbunden (Ruegg and Pantoja, 2013). Diese akuten Mastitisfälle können vom Landwirt erkannt und die Tiere adäquat behandelt werden (Nyman et al., 2007). Darüber hinaus gibt es jedoch auch die subklinischen Mastitiden, deren Existenz nur über eine Erhöhung des Zellgehalts oder die Identifizierung des Erregers nachgewiesen werden kann (Ruegg und Pantoja, 2013). Die meisten Mastitiden werden durch Umweltkeime (E.coli, Strept. uberis) oder über direkten Tierkontakt (Staph. aureus, Strept. dysgalactiae, Strept. agalactiae) ausgelöst (Bradley, 2002). Als Risikofaktoren für das Auftreten von Mastitiden gelten verschmutzte Euter (Breen et al., 2009), hohe Milchleistungen (Ingvartsen et al., 2003) oder die Haltung in Strohställen (Barnouin et al., 2005).

\section{Klauenerkrankungen}

Lahmheiten aufgrund von Klauenerkrankungen werden sowohl von Landwirten, als auch von Tierärzten als gravierendes Tierwohlproblem eingestuft (Bauman et al., 2016). Darüber hinaus sind sie auch von großer ökonomischer Bedeutung (Cha et al., 2010). Im Schnitt müssen Landwirte in den Niederlanden für die Behandlung von Klauenerkrankungen 53 Euro pro Kuh und Jahr aufwenden (Bruinjis et al., 2012). Leach et al. (2010) wiesen in Großbritannien im Mittel 36\% lahme Tiere nach. Eine vergleichbare Prävalenz an Lahmheiten wurde mit 32\% (Spanne 0-98\%) auch in niederländischen Milchviehbetrieben nachgewiesen (de Vries et al., 2013). Große Variationen zwischen den Betrieben zeigten sich auch bei einer Untersuchung in Kanada. Solano et al. (2015) berichten von einer durchschnittlichen Prävalenz von 21\% und einer Spanne von 0-69\% lahmen Tieren. Diese Ergebnisse lassen auf einen großen Einfluss der Haltungsumwelt und des Managements auf das Lahmheitsgeschehen schließen (Bicalho et al., 2013). 
Das Lahmheitsrisiko steigt beispielsweise mit verlängerten Standzeiten auf nassen und schmutzigen Böden (King et al., 2016). Weitere Riskofaktoren für Lahmheit sind hohe Milchleistungen (Green, 2002), ungenügende Körperkondition (Espejo et al., 2006) und die Rasse Holstein (Barker et al., 2010). Förderlich für die Klauengesundheit sind hingegen Tiefboxen mit ausreichender Einstreu (Cook et al., 2016), regelmäßige Klauenpflege (Espejo und Endres, 2007) oder das Angebot von Weidegang (Haskell et al., 2006).

\section{Stoffwechselstörungen}

Milchkühe sind insbesondere unmittelbar nach der Geburt und in den ersten Wochen der Laktation anfällig für Stoffwechselerkrankungen (Stengärde et al., 2012). Zu den bedeutendsten Stoffwechselstörungen im postnatalen Zeitraum gehören Pansenazidose, Ketose und Milchfieber. Pansenazidose kann in einer akuten und in einer subakuten Form auftreten und wird durch Fütterungsfehler hervorgerufen. Hohe Kraftfuttergaben in Kombination mit geringer Grundfutteraufnahme können zu einer Übersäuerung des Pansens führen (Plaizier et al., 2008). Pansenazidose kann eine fütterungsbedingte Klauenentzündung (Laminitis) begünstigen und das Lahmheitsrisiko in der Herde erhöhen (Stone, 2004).

Ketose entsteht aufgrund eines Energiedefizits zu Beginn der Laktation. Glucosemangel führt zu einem verstärkten Abbau von Körperfettreserven und in der Folge zur Bildung von sogenannten Ketonkörpern (Berge und Vententen, 2014). Die Tiere verweigern daraufhin die Futteraufnahme und die Körperkondition wird negativ beeinflusst (Raboisson et al., 2014). Durch eine angepasste Fütterung kann eine Verfettung der Tiere in der Trockenstehphase vermieden und das Risiko einer Ketose deutlich reduziert werden (Stengärde et al., 2012).

Milchfieber entsteht unmittelbar nach der Geburt des Kalbes durch einen akuten Calciummangel in Folge der einsetzenden Milchbildung (Neves et al., 2017). Milchfieber ist charakterisiert durch reduzierten Appetit, Schwäche und Koordinationsstörungen. Symptomatisch sind zudem kühlere Haut und Hautanhangsorgane (Sogstad et al., 2006). Kühe in späteren Laktationen neigen zu Milchfieber und liegen dann nach der Geburt fest. Prophylaktische Calciumgaben und angepasste Trockensteherfütterung können das Risiko minimieren (Goff, 2008). 


\section{Kälberenthornung}

Die Enthornung von Kälbern ist ein routinemäßiges Managementverfahren zur Vermeidung von hornbedingten Verletzungen bei Mensch und Tier (Gottardo et al., 2011; M'hamdi et al., 2013). Der Eingriff wird üblicherweise bei jungen Kälbern durch den Landwirt selbst und ohne Einsatz von Betäubungsmitteln durchgeführt (Stock et al., 2013). Mit Hilfe eines Brennstabes werden dabei die Hornanlagen thermisch behandelt und bei korrekter Anwendung der Technik das Hornwachstum dauerhaft unterbrochen (Gottardo et al., 2011). Ab einem Alter von 6 Wochen darf die Enthornung laut deutschem Tierschutzgesetz nur unter Einsatz von Betäubungsmitteln durchgeführt werden (TSchG, 2017). Zahlreiche wissenschaftliche Studien belegen, dass die betäubungslose Enthornung für die Tiere schmerzhaft ist und sie unter den Folgen des Eingriffs über einen längeren Zeitraum leiden können (Faulkner und Weary, 2000; Stock et al., 2013). Einige Bundesländer schreiben daher mittlerweile die Gabe eines Beruhigungsmittels (Sedativum) und eines Schmerzmittels (Analgetikum) vor, um die Beeinträchtigungen der Kälber während des Eingriffs und des anschließenden Heilungsprozesses zu minimieren. Die betäubungslose Enthornung von Kälbern steht zunehmend in der gesellschaftlichen Kritik und wird von vielen Verbrauchern abgelehnt (Robbins et al., 2015; Widmar et al., 2017). Es ist daher sehr wahrscheinlich, dass die medikamentöse Behandlung der Kälber zukünftig bundesweit vorgeschrieben wird. Durch den verstärkten Einsatz genetisch hornloser Bullen könnte die Enthornung von Kälbern jedoch über kurz oder lang überflüssig werden.

\section{Artgemäßes Verhalten}

Die Weidehaltung von Milchkühen hat im Zuge des Strukturwandels immer mehr an Bedeutung verloren. Im Jahr 2010 wurden nur noch etwa 42\% der Milchkühe in Deutschland regelmäßiger Weidegang angeboten (Lindena et al., 2017). Dadurch können Milchkühe viele ihrer typischen Verhaltensweisen wie (z.B. Grasen) nicht mehr ausüben und haben auch nicht die Möglichkeit sich unterschiedlichen Klimareizen auszusetzen (Wissenschaftlicher Beirat, 2015; Arnott et al., 2016). Zahlreiche Studien belegen potentiell positive Effekte des Weidegangs auf Gesundheitsparameter wie z.B. Lahmheit (Haskell et al., 2006; Cook et al., 2016), Klauenerkrankungen (Armbrecht et al., 2018) oder Integumentschäden (Burow et al., 2013; Wagner et al., 2018). Die Weidehaltung kann jedoch nur förderlich 
für die Gesundheit der Milchkühe sein, wenn bestimmte Voraussetzungen wie z.B. Verfügbarkeit von Schatten, ausreichende Wasserversorgung und angemessener Grünlandaufwuchs erfüllt sind (von Keyserlingk et al., 2009; Charlton und Rutter, 2017). Ein weiteres Problemfeld in der Milchviehhaltung sind die immer noch weit verbreiteten Anbindeställe. Trotz insgesamt abnehmender Bedeutung gibt es in Deutschland zahlreiche Betriebe mit Anbindehaltung. Im Jahr 2010 hatten noch 54\% der Betriebe Anbindeställe, wobei in diesen aufgrund der üblicherweise geringeren Bestandsgröße nur 27\% der Milchkühe gehalten wurden. Diese Haltungsform schränkt die Bewegungsfreiheit der Milchkühe stark ein und ist deswegen zur Vermeidung von haltungsbedingten Verhaltensproblemen abzulehnen (Wissenschaftlicher Beirat, 2015). Die Haltung von Milchkühen in Laufställen bietet den Tieren vielfältigere Bewegungsmöglichkeiten und wirkt sich positiv auf das Tierwohlniveau in den Betrieben aus (Popescu et al., 2014).

\section{Soziales Verhalten}

Milchkühe zeigen unter natürlichen Haltungsbedingungen üblicherweise ein herdensynchrones Verhalten, d.h. Futteraufnahme und Ruhephasen werden nach Möglichkeit zeitgleich ausgeführt (Schrader, 2009). In Betrieben mit einem geringen Ressourcenangebot (z.B. Liegeboxen, Fressplätze) können sie dieses Verhaltensbedürfnis jedoch nicht ausleben (de Vries et al., 2016). Insbesondere rangniedere Kühe müssen bei einer begrenzten Anzahl von Liegeboxen und Fressplätzen auf die Nutzung derselben warten und sind dadurch erheblich in ihrer persönlichen Entscheidungsfreiheit eingeschränkt. Desweiteren können hohe Bestandsdichten zu einer erhöhten Anzahl von agonistischen Interaktionen am Futtertisch (Black et al., 2016) oder im Liegebereich (Fregonesi et al., 2007) führen. Dadurch wird das Stresslevel in der Herde erhöht und rangniedere sowie kranke Tiere müssen ihre Verhaltensweisen ändern, um Konflikten aus dem Weg zu gehen (Chebel et al., 2016; Jensen und Proudfoot, 2017). Möglicherweise trägt auch das Angebot von zusätzlichen Beschäftigungselementen für die individuelle Nährstoffversorgung oder den Kuhkomfort, wie z.B. Kraftfutterstationen oder Kuhbürsten, zu einem erhöhten Konfliktpotenzial bei. Diese limitierte Ressourcen können in der Praxis zu einem Anstieg von Kopfstößen und Vertreibungen führen und damit die Unruhe im Milchviehstall erhöhen (de Vries et al., 2015). 
Darüber hinaus werden die Milchkühe in größeren Herden üblicherweise mehrmals in einer Laktation umgruppiert, um die Tiere in verschiedenen Fütterungsgruppen entsprechend ihres Milchleistungsniveaus versorgen zu können (Boe und Faerevik, 2003). Häufiges Umgruppieren könnte jedoch zu vermehrten agonistischen Interaktionen wie Kopfstößen und Vertreibungen führen, da sich die Tiere unbekannt sind und immer wieder neue Rangordnungen ausgekämpft werden müssen (Boe und Faerevik, 2003; Estevez et al., 2007).

\section{Mensch-Tier-Beziehung}

Im Zuge des Strukturwandels steigen die durchschnittlichen Bestandsgrößen an und die Herdenbetreuer müssen sich parallel um eine größere Anzahl an Tieren kümmern (Raussi, 2003). Steigende Bestandsgrößen können in der Folge zu einer Abnahme der täglichen körperlichen Kontakte zwischen den Milchkühen und ihren Betreuern führen (Waiblinger und Menke, 1999). Technische Innovationen wie die Einführung von automatischen Melksystemen haben durch die fehlenden gemeinsamen Melkzeiten ebenfalls dazu beigetragen, die Anzahl der Kontakte zwischen Mensch und Tier zu reduzieren (Jacobs und Siegford, 2012). Die Mensch-Tier-Beziehung kann aufgrund seltenerer sozialer Kontakte zwischen Menschen und Kühen deutlich schwächer ausgeprägt sein (Robbins et al., 2016).

Durch die geringere Gewöhnung der Milchkühe an den Menschen sind notwendige Managementmaßnahmen wie Klauenschneiden oder künstliche Besamung für die Tiere mit akutem Stress verbunden. Fluchtversuche können dadurch potentiell zu erheblichen Schäden an den Tieren führen und das Verletzungsrisiko der Herdenbetreuer deutlich erhöhen (De Boyer des Roches et al., 2016). Eine gute Mensch-Tier-Beziehung trägt jedoch nicht nur zur Vermeidung von Stress und der Erhöhung der Arbeitssicherheit bei, sondern kann sich auch positiv auf die Gesundheit und Leistung von Milchkühen auswirken. Ivemeyer et al. (2011) zeigten einen positiven Zusammenhang zwischen einer guten Mensch-Tier-Beziehung und niedrigen Zellzahlgehalten in der Milch. Darüber hinaus wurden in einer österreichischen Studie höhere Milchleistungen in Betrieben nachgewiesen, deren Mitarbeiter dem täglichen Umgang mit den Milchkühen gegenüber positiv eingestellt waren (Waiblinger et al., 2002). 


\subsection{Erhebung von Tierwohl in der Nutztierhaltung}

Zur Einschätzung des betriebsindividuellen Tierwohlniveaus werden in wissenschaftlichen Untersuchungen Tierwohlindikatoren verwendet, da sich das Tierwohl aufgrund seiner Subjektivität nicht direkt messen lässt (Aerts et al., 2006). Tierwohlindikatoren geben Hinweise auf potentielle Risikofaktoren im Betrieb, die das Tierwohl negativ beeinflussen könnten (Main et al., 2003). Für eine wissenschaftliche Beurteilung des TierwohIniveaus müssen die verwendeten Indikatoren hohen Ansprüchen an Validität (Bedeutsamkeit für das Tierwohl), Reliabilität (Wiederholbarkeit der Erfassung) und Praktikabilität (Kosten-Nutzen-Aufwand) genügen (Knierim und Winckler, 2009). Im Laufe der letzten Jahrzehnte wurden zahlreiche verschiedene Tierwohlindikatoren entwickelt, die sich im Grundsatz jedoch alle in die beiden Gruppen der ressourcen- oder tierorientierten Indikatoren einteilen lassen (Main et al., 2003; Whay, 2007; de Vries et al., 2011).

Die Gruppe der ressourcenorientierten Indikatoren betrachtet in erster Linie die Umweltbedingungen der Tiere, d.h. die Gestaltung des Haltungssystems oder die Managemententscheidungen der Landwirte (Capdeville und Veissier, 2001). Dabei stehen insbesondere die in ihrer Haltungsumwelt zur Verfügung stehenden Ressourcen und ihre potentiellen Auswirkungen auf die Gesundheit und das Verhalten der Tiere im Fokus (Butterworth et al., 2011; Veissier et al., 2012). Die Indikatoren werden entweder direkt innerhalb des Stalles gemessen (Haltungsindikatoren) oder im Rahmen von Betriebsleiterinterviews (Managementindikatoren) erfragt. Die Haltungsindikatoren beziehen sich dabei hauptsächlich auf die baulich-technische Infrastruktur in den Nutztierställen. Beispiele hierfür sind: Liegeflächengestaltung, Futterplatzgestaltung, Stallklimaführung oder Platzangebot. Die Managementindikatoren betrachten hingegen die von Seiten des Tierhalters auf das Tier einwirkenden Umwelteinflüsse. Hierzu zählen beispielsweise tägliche Routinearbeiten wie Melken, Fütterung oder die allgemeine Gesundheitsvorsorge. Wie Abbildung 2.4 anschaulich zeigt, wirken sich sowohl Haltungssystem, als auch Managementpraxis auf Tierverhalten und Tiergesundheit als wichtige Merkmale des Tierwohls aus. Darüber hinaus existieren zwischen beiden Einflussfaktoren komplexe, wechselseitige Wirkbeziehungen (Interaktionen), so dass diese nicht unabhängig voneinander betrachtet werden können (Heise, 2017). 


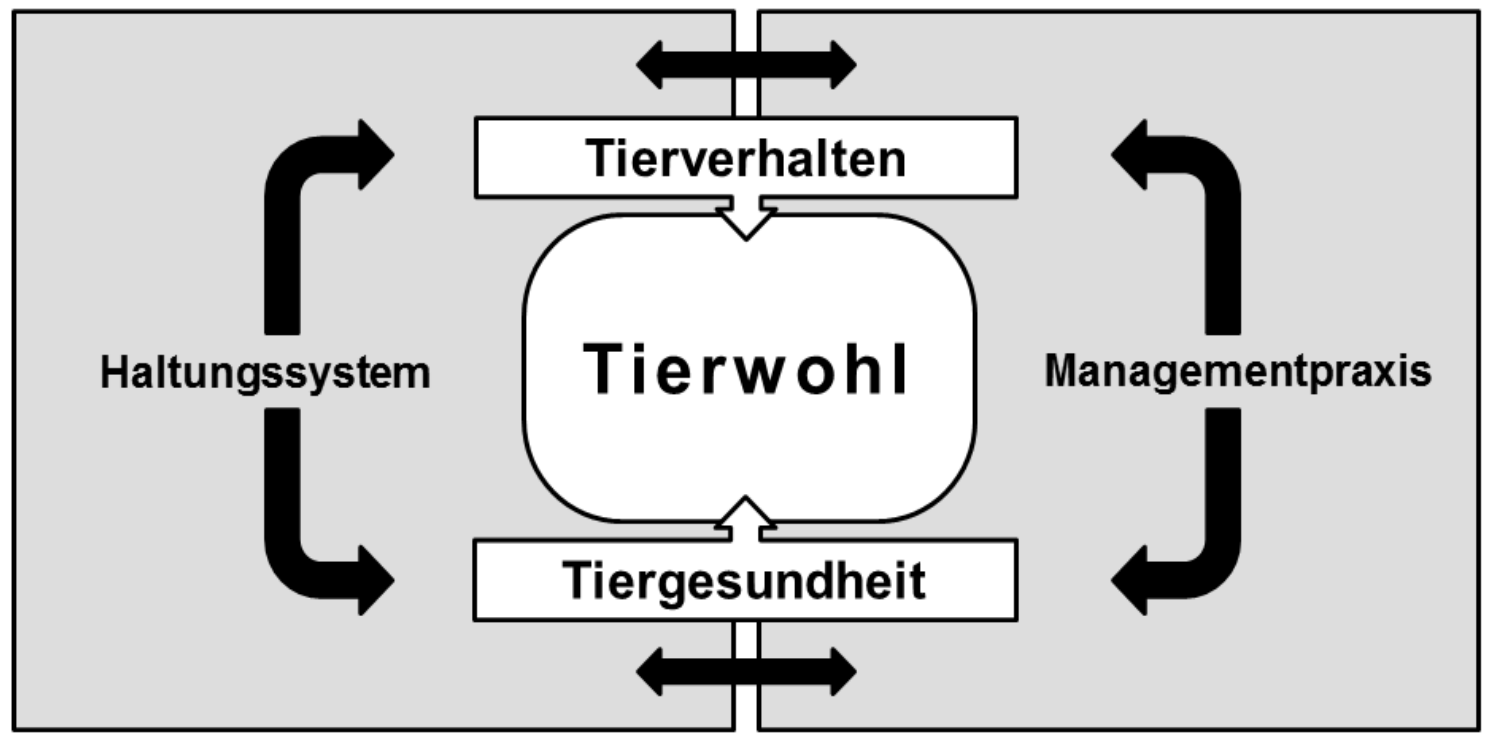

Figure 2.4: Wechselbeziehungen von Haltung, Management und Tierwohl (Quelle: Heise, 2017).

Ressourcenorientierte Indikatoren können in der Regel einfach, schnell und verlässlich erhoben werden und erfordern in der Anwendung keine vertieften Kenntnisse (Johnsen et al., 2001; Knierim und Winckler, 2009). Mit ihrer Hilfe sollen die Risikofaktoren in den Betrieben identifiziert und dadurch das jeweils vorhandene Tierwohlniveau abgeleitet werden (Waiblinger et al., 2001; Miele et al., 2011). Das theoretische Konzept der ressourcenorientierten Indikatoren beruht auf der Annahme, dass vorschriftsmäßige Haltungsbedingungen und Managemententscheidungen per se zu einem akzeptablen Tierwohlniveau führen (Whay, 2007). Dieser vermutete unmittelbare Zusammenhang zwischen den vorherrschenden Umweltbedingungen und dem tatsächlichen Tierwohlniveau lässt sich wissenschaftlich jedoch nicht belegen. Die alleinige Betrachtung der ressourcenorientierten Indikatoren steht aufgrund ihrer mangelnden Validität in der Kritik (Winckler et al., 2003; Hemsworth et al., 2009).

Aus diesem Grund werden in der Forschung zunehmend die Tiere selbst in die Beurteilung des Tierwohlniveaus einbezogen (Capdeville und Veissier, 2001; de Vries et al., 2011). Tierorientierte Indikatoren betrachten die Reaktion der Tiere auf spezifische Umweltbedingungen und erlauben so direkte Rückschlüsse auf ihr Wohlergehen (Johnsen et al., 2001; Whay et al., 2007). Tierorientierte Indikatoren werden durch Beobachtungen auf Einzeltier- und Gruppenebene oder durch die Auswertung vorliegender Betriebsdaten erhoben (Main et al., 2004; Webster, 2005; Main et al., 2007). Zu den tierorientierten Indikatoren werden u.a. 
physiologische Indikatoren wie erhöhte Glucokortikosteroidgehalte im Blutplasma (Waiblinger, 2012), pathologische Indikatoren wie Krankheiten oder Verletzungen (Broom und Fraser, 2007) oder ethologische Indikatoren wie Spielverhalten oder Körperpflege (Winckler et al., 2003) gezählt. Tierorientierte Indikatoren sind in der Regel sehr valide, d.h. sie geben wissenschaftlich fundierte Hinweise auf das Tierwohlniveau in den Betrieben. Dennoch besitzen sie auch einige gravierende Nachteile. Die Anwendbarkeit der tierorientierten Indikatoren in der Praxis wird kritisch beurteilt, da ihre Erhebung sehr zeitintensiv und z.T. mit hohen Kosten verbunden ist (Knierim und Winckler, 2009; Rushen und de Passillé, 2009). Durch die Komplexität der tierorientierten Indikatoren sind ausreichend qualifizierte Kontrolleure notwendig, um die korrekte Anwendung in der Praxis gewährleisten zu können (Waiblinger et al., 2012). Die Interpretation einzelner Ergebnisse ist zudem nicht immer eindeutig und die Festlegung von allgemeingültigen Grenzwerten für viele tierorientierte Indikatoren problematisch (Johnsen et al., 2001; Whay, 2007).

Aufgrund der genannten Limitationen kann keine der beiden Indikatorgruppen alleine sämtliche Dimensionen des Tierwohls erfassen (Botreau et al., 2007; Butterworth, 2009). Daher werden in der Tierwohlforschung mehrere Perspektiven kombiniert, um die Validität, Reliabiltät und Praktikabilität innerhalb von Bewertungssystemen zu optimieren (Sandoe et al., 2003; Waiblinger, 2012). Für eine umfassende Beurteilung des Tierwohls sollten wissenschaftlichen Erkenntnissen zufolge sowohl die beiden Umweltfaktoren Haltung und Management, als auch das Tier selbst in die Betrachtung einbezogen werden (Knierim, 2002; Webster, 2003; Rousing et al., 2007). Dabei sollten tierorientierte Indikatoren bei vertretbarem zeitlichen und finanziellen Aufwand aufgrund ihrer höheren Aussagekraft gegenüber ressourcenorientierten Indikatoren stets bevorzugt verwendet werden (Butterworth et al., 2011). Nichtsdestotrotz können etablierte Indikatoren aus den Bereichen Haltung und Management auch weiterhin genutzt werden, sofern sie Mindestanforderungen an die Validität erfüllen (Main et al., 2004). Dieser integrative Ansatz wird in den meisten Indikatorensystemen zur Beurteilung des Tierwohlniveaus verwendet, da sich die ressourcenorientierten Indiktoren aufgrund der methodischen Limitationen nicht gänzlich durch tierorientierte Indikatoren ersetzen lassen (Rushen und de Passillé, 2009; de Vries et al., 2011). 


\subsection{Beurteilung von Tierwohl in der Milchviehhaltung}

Zur Beurteilung des betriebsindividuellen Tierwohlniveaus ist es notwendig, die auf Betriebsebene erfassten Tierwohlindikatoren mit Referenzwerten zu vergleichen, hinsichtlich ihrer Bedeutung für das Tierwohl zu gewichten und zu einer Gesamtbewertung zu aggregieren (Rushen, 2003; Deimel et al., 2010). In den letzten Jahrzehnten wurden verschiedene Systeme zur Beurteilung des Tierwohls auf Betriebsebene entwickelt, die sich jedoch bislang nicht dauerhaft in der Praxis durchsetzen konnten. Beispielhaft seien hier aus dem deutschen Sprachraum der Tiergerechtheitsindex 35 von Bartussek et al. (1996), der Tiergerechtheitsindex 200 von Sundrum und Andersson (1994) oder die Kritischen Kontrollpunkte von Sanftleben et al. (2007) genannt. Diese Beurteilungssysteme sind jedoch hauptsächlich auf den Bereich der Haltungs- und Managementfaktoren fokussiert und betrachten entgegen des aktuellen wissenschaftlichen Standards in der Tierwohlforschung nur wenige tierorientierte Indikatoren.

In jüngerer Vergangenheit wurde von Experten der Landwirtschaftskammer Nordrhein-Westfalen die Beurteilungshilfe "Cows and More" entwickelt (Pelzer et al., 2007). Dieses Indikatorensystem zur Schwachstellenanalyse in Liegeboxenlaufställen dient der objektiven und systematischen Erfassung tierbezogener Paramter, wie z.B. Laufverhalten, Abliegeverhalten, Liegepositionen oder Verschmutzungsgrad (Dahlhoff, 2014). "Cows and More" ist eine Software, die mit Hilfe eines Tablets direkt im Stall angewendet werden kann. Durch Verhaltensund Einzeltierbeobachtungen werden die Schwachstellen des jeweiligen Milchviehbetriebs identifiziert und potentielle Risikofaktoren, wie z.B. inadäquate Liegeboxenabmessungen, abgeleitet. Basierend auf Expertenwissen werden im Folgenden systematische Vorschläge zur Optimierung der Haltungsumwelt und des Managements unterbreitet (Dahlhoff, 2014). Der Fokus dieses Instruments liegt in der landwirtschaftlichen oder veterinärmedizinischen Beratung und mit seiner Hilfe sollen in erster Linie die wichtigsten Problemfelder des Betriebes erkannt werden. "Cows and More" erhebt nicht den Anspruch, sämtliche Tierwohlprobleme in allen Bereichen des Haltungssystems aufdecken zu können und ist demzufolge nicht uneingeschränkt zur Beurteilung des generellen Tierwohlniveaus auf Betriebsebene geeignet. 
Ein weiteres Indikatorensystem zur Beurteilung von Tierwohl in Milchviehbetrieben stellt der KTBL-Leitfaden für Rinder dar (Brinkmann et al., 2016). Dieser enthält zahlreiche tierbasierte Indikatoren, die Aufschluss über die relevantesten Tierwohlprobleme (z.B. Lahmheit, Mastitis oder Integumentschäden) auf den Betrieben geben sollen. Die Tierwohlindikatoren wurden durch Expertenteams unter Koordination des Kuratoriums für Technik und Bauwesen in der Landwirtschaft (KTBL) für den Einsatzzweck der betrieblichen Eigenkontrolle ausgewählt. Laut Tierschutzgesetz ( $\$ 11$ Abs. 8) ist jeder Nutztierhalter dazu verpflichtet, selbstständig tierbezogene Tierschutzindikatoren zu erheben und zu bewerten, um die Anforderungen von $\S 2$ „Tierhalternorm“ nachweisen zu können (TSchG, 2017). Es wurden in erster Linie tierbasierte Tierwohlindikatoren aus dem Bereich der Tiergesundheit in den KTBL-Leitfaden aufgenommen, da diese durch die Landwirte sicher und wiederholbar erhoben werden können. Demgegenüber sind nur sehr wenige Tierwohlindikatoren aus dem Bereich des Tierverhaltens im Leitfaden enthalten. Verhaltensbeobachtungen sind sehr zeitaufwändig und wurden daher aus Praktikabilitätsgründen nur in geringem Umfang berücksichtigt (Zapf et al., 2015). Der KTBL-Leitfaden für Rinder ist eine nützliche Managementhilfe zur Identifikation der wichtigsten Tierwohlprobleme, jedoch erlaubt seine Anwendung keine generelle Einschätzung des betriebsindividuellen Tierwohlniveaus.

Ein umfassenderes Beurteilungssystem unter Einbeziehung einer Vielzahl von tierorientierten Indikatoren aus den Bereichen Tiergesundheit und Tierverhalten wurde im Rahmen des internationalen Welfare Quality ${ }^{\circledR}$ Projekts entwickelt. Dieses von der Europäischen Union im Zeitraum von 2004 bis 2009 geförderte Projekt, sollte einen Beitrag zur nachhaltigen Verbesserung des Tierwohlniveaus innerhalb der gesamten Lebensmittelkette leisten (Canali und Keeling, 2009; Manteca et al., 2009). Das Ziel des Welfare Quality ${ }^{\circledR}$ Projekts war es, valide, reliable und praktikable Tierwohlindikatoren zu entwickeln, einen einheitlichen europäischen Standard zur Erhebung des Tierwohlniveaus zu etablieren und bisherige gesellschaftliche und wissenschaftliche Erkenntnisse der Tierwohlforschung zu bündeln (Blokhuis, 2008; Manteca et al., 2009). Innerhalb des Projekts erarbeiteten 44 Institute und Universitäten aus 13 EU-Ländern und 4 lateinamerikanischen Staaten standardisierte Indikatorensysteme für die Tierarten Rind, Schwein und Geflügel (Canali und Keeling, 2009; Veissier et al., 2009). 
In der vorliegenden Arbeit wurde das Welfare Quality ${ }^{\circledR}$ Protokoll für Rinder (Welfare Quality, 2012) angewendet, da es die Möglichkeit einer umfassenden Beurteilung des Tierwohlniveaus mit Hilfe zahlreicher tierorientierter Indikatoren bietet. Im folgenden Abschnitt wird der Aufbau des WQP für Rinder vorgestellt. Abbildung 2.5 veranschaulicht die Struktur des WQP von der Ebene der Tierwohlindikatoren bis zur Ebene des Gesamturteils. Das Welfare Quality ${ }^{\circledR}$ System beinhaltet vier verschiedene Stufen, über die aus den ursprünglich etwa 30 Messwerten (Measures) in einem hierarchischen Aggregierungsprozess 12 Kriterien (Criteria), 4 Prinzipien (Principles) und schließlich ein einziges Gesamturteil (Overall assessment) gebildet wird.

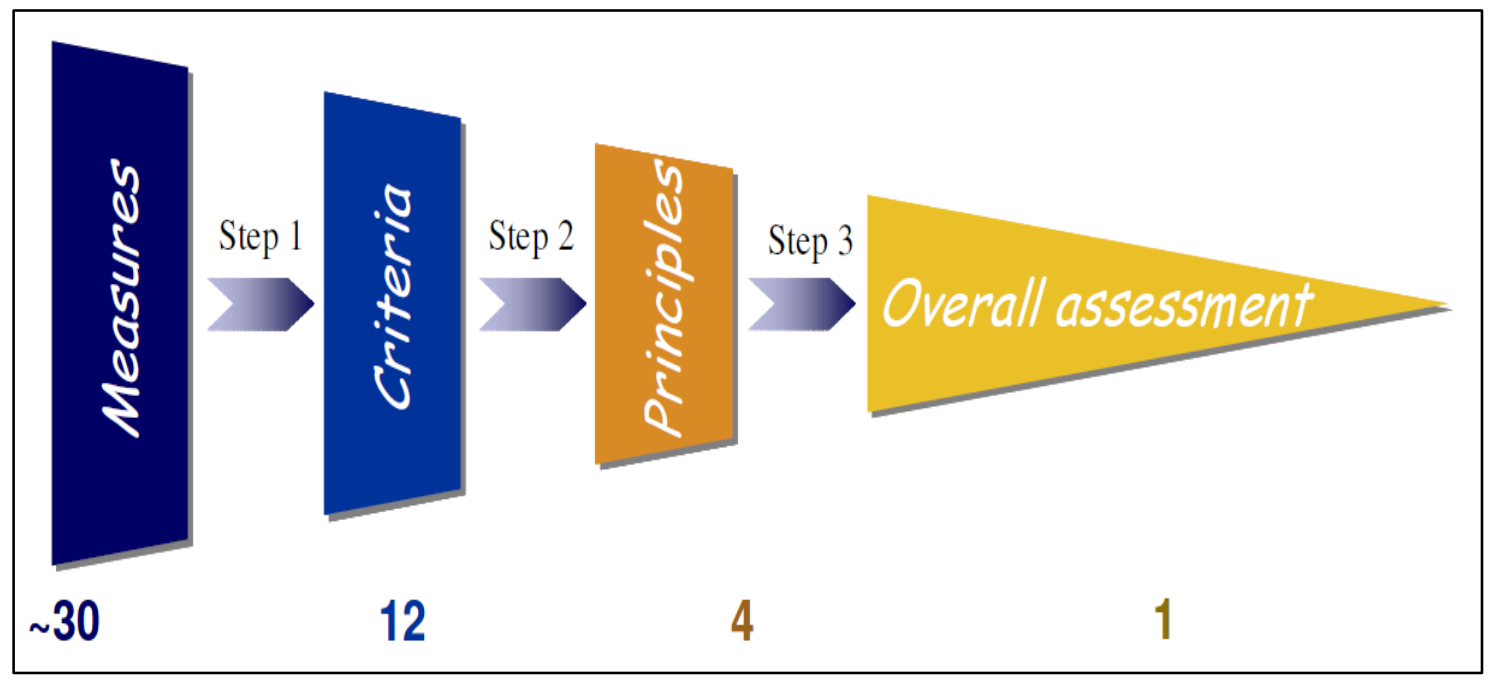

Figure 2.5: Modell des Welfare Quality ${ }^{\circledR}$ Protokolls für Rinder von der Ebene der Tierwohlindikatoren zur Ebene des Gesamturteils (Welfare Quality, 2012).

Das Welfare Quality ${ }^{\circledR}$ Protokoll für Rinder enthält je nach Haltungsform (Anbindehaltung oder Laufstallhaltung) etwa 30 Tierwohlindikatoren (siehe Tabelle 2.2). Lediglich einige Managementinformationen (Anbindehaltung, Weidegang oder Enthornungsprozess) und die Wasserversorgung der Tiere werden ressourcenorientiert ermittelt. Darüber hinaus werden alle anderen Tierwohlindikatoren entweder direkt (Körperkondition, Liegekomfort, Sauberkeit, Integumentschäden, Lahmheiten, Krankheiten, Sozialverhalten, Vermeidungsdistanz, emotionaler Zustand) oder indirekt (Mastitis, Schwergeburt, Festliegen, Mortalität) am Tier erhoben. Indikatoren für das Kriterium Klimakomfort wurden noch nicht entwickelt und demzufolge konnte bei der Tierwohlbeurteilung Hitze- oder Kältestress bei den Kühen bisher nicht berücksichtigt werden. 
Table 2.2: Darstellung der Prinzipien, Kriterien und Indikatoren des WQP für Rinder (2012).

\begin{tabular}{|c|c|c|c|}
\hline Bewertung & Prinzipien & Kriterien & Indikatoren \\
\hline \multirow{14}{*}{$\begin{array}{l}\text { Gesamt- } \\
\text { Score }\end{array}$} & & 01 Hunger & Körperkondition \\
\hline & Fütterung & & \\
\hline & & 02 Durst & Troglänge, Durchfluss, Sauberkeit \\
\hline & & 03 Liegekomfort & $\begin{array}{l}\text { Abliegedauer, Kollisionen, Sau- } \\
\text { berkeit Beine, Flanke, Euter... }\end{array}$ \\
\hline & Haltung & 04 Klimakomfort & -------------------------------- \\
\hline & & 05 Bewegungsfreiheit & Anbindehaltung, Laufstall \\
\hline & & 06 Verletzungen & Integument, Lahmheit \\
\hline & Gesundheit & 07 Krankheiten & $\begin{array}{l}\text { Ausfluss, Husten, Durchfall, Mas- } \\
\text { titis, Schwergeburt, Mortalität... }\end{array}$ \\
\hline & & 08 Schmerzen & Enthornung, Schwanz kupieren \\
\hline & & 09 Sozialverhalten & Kopfstöße, Vertreibungen \\
\hline & & 10 Sonstiges Verhalten & Angebot von Weidegang \\
\hline & Verhalten & & \\
\hline & & 11 Mensch-Tier-Beziehung & Vermeidungsdistanztest \\
\hline & & 12 Emotionaler Zustand & Qualitative Verhaltensbeurteilung \\
\hline
\end{tabular}

Die erhobenen Indikatorwerte werden über verschiedene mathematische Einstufungsverfahren (z.B. Entscheidungsbäume bei der Wasserverfügbarkeit; ISpline-Funktionen beim Anteil magerer Kühe oder Vergleich mit Warn- und Schwellenwerten bei den Krankheitsindikatoren) in die 12 Tierwohlkriterien transfomiert. Dabei können jeweils Scores von 0 (schlechtestes Tierwohlniveau) bis 100 (bestes Tierwohlniveau) erreicht werden. Die zwölf Kriterien werden im Anschluss mit Hilfe von Choquet-Integralen entsprechend ihrer vermuteten Bedeutung für das Tierwohl zu den vier Tierwohlprinzipien Fütterung, Haltung, Gesundheit und Verhalten zusammengefasst. Die Gesamtbewertung erfolgt dabei bewusst nicht über die Berechnung eines Mittelwertes aus den vier Prinzipien, um eine mögliche Kompensation gravierender Tierwohldefizite durch höhere Punktzahlen in anderen Prinzipien zu verhindern. 
Die Betriebe werden anhand von im WQP angegebenen Schwellenwerten in die Kategorien „Exzellent“, „Verbessert" oder „Akzeptabel“ eingestuft. Erfüllten sie die jeweiligen Anforderungen nicht, werden sie als "nicht klassifiziert“ bewertet. Für eine exzellente Bewertung sind in jedem Prinzip 55 Punkte erforderlich und in zwei von innen jeweils mindestens 80 Punkte. Eine Klassifizierung als verbesserter Betrieb wird erreicht, wenn durchgängig 20 Punkte überschritten und mindestens 55 Punkte in zwei Prinzipien erreicht werden. Als akzeptabel gelten Betriebe, die stets mehr als 10 Punkte erzielen und in drei Prinzipien oberhalb von 20 Punkten liegen. Abbildung 2.6 zeigt Beispiele für Betriebe mit verschiedenen WQP-Klassifizierungen (Welfare Quality, 2012).

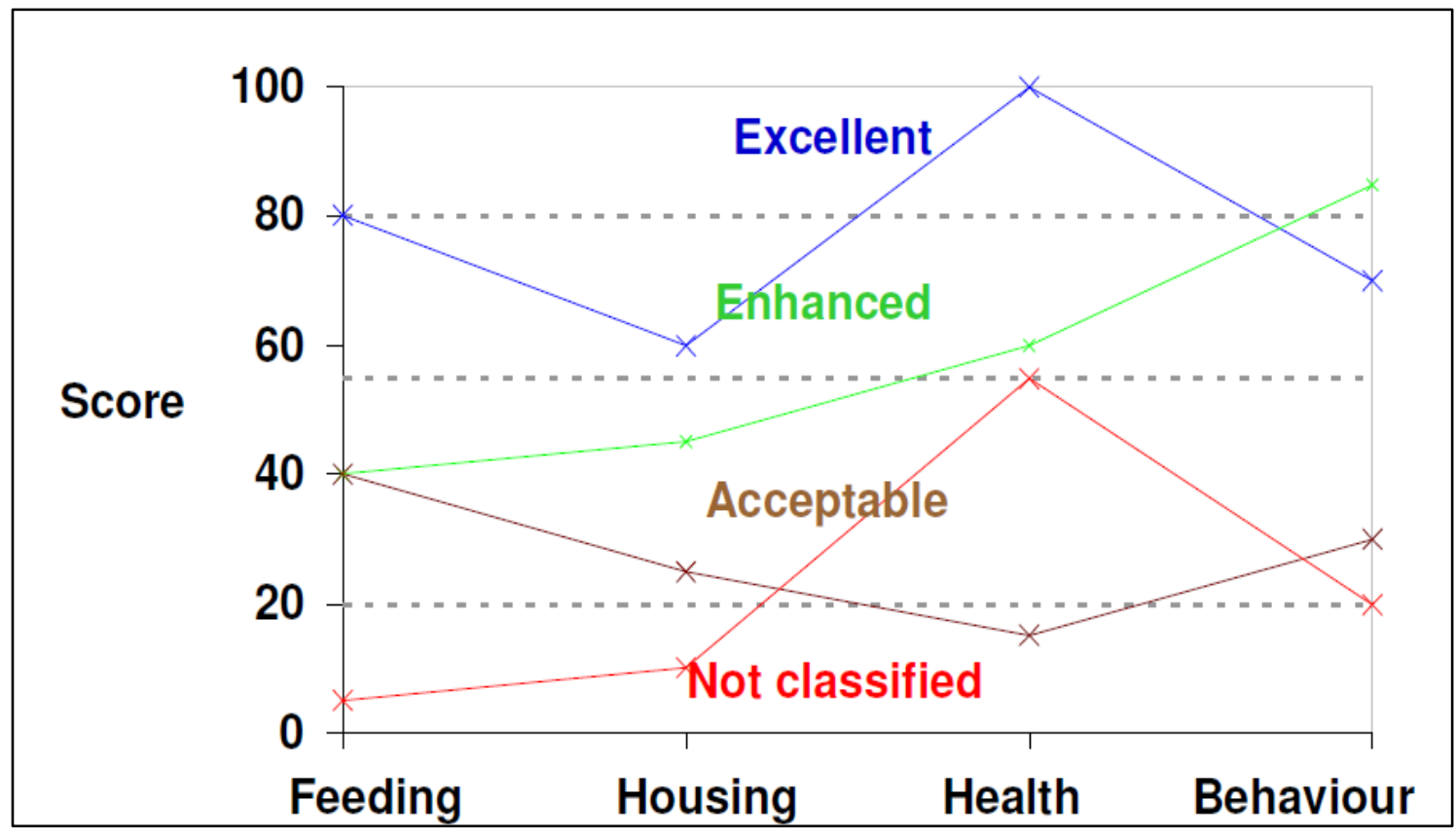

Figure 2.6: Beispiele für Betriebe mit verschiedenen WQP-Klassifizierungen „Exzellent“, „Verbessert“, „Akzeptabel“ und „nicht klassifiziert“ (Welfare Quality, 2012).

Das Welfare Quality ${ }^{\circledR}$ Protokoll für Rinder ist in der Wissenschaft weitestgehend anerkannt und wird in einigen, zumeist europäischen Forschungseinrichtungen zur Beurteilung des Tierwohlniveaus angewendet (u.a. de Vries et al., 2013; Coignard et al., 2013; Andreasen et al., 2014; Heath et al., 2014a; de Graaf et al., 2017a). Das WQP stellt für die Wissenschaft ein nützliches Instrument zur Beurteilung des Tierwohlniveaus auf Betriebsebene dar, sofern die vorhandenen methodischen Limitationen bei der Interpretation der Ergebnisse berücksichtigt werden (Gieseke et al., 2014; Heath et al., 2014b; de Graaf et al., 2017b). 
Beispielsweise haben einzelne Tierwohlindikatoren wie Wasserversorgung oder der Anteil magerer Kühe einen überproportionalen Effekt auf die WQP-Klassifizierung. Dagegen sind andere Tierwohlindikatoren aus dem Bereich der Tiergesundheit (z.B. Lahmheit oder Mastitis) für die Höhe des Gesamturteils von nachrangiger Bedeutung. Betriebe mit einer ausreichenden Wasserversorgung erhielten demzufolge gute Tierwohlbewertungen, obwohl die Kühe z.T. deutliche Gesundheitsprobleme aufwiesen (de Vries et al., 2013). Die Gewichtungsformeln innerhalb des Aggregationsprozesses wurden auch von anderen Autoren als kritisch beurteilt und eine zukünftige Überarbeitung der Berechnungsformeln daher dringend empfohlen (Heath et al., 2014a,b; de Graaf et al., 2017b; Sandoe et al., 2017; de Graaf et al., 2018).

Darüber hinaus könnte die im WQP vorgesehene Stichprobenziehung für die klinischen Beurteilungen von Einzeltieren (z.B. Lahmheit, magere Kühe oder Sauberkeit) die Ergebnisse der Tierwohlbeurteilung maßgeblich beeinflussen (Van Os et al., 2018). Die Stichprobengröße hängt im WQP für Rinder von der Bestandsgröße ab, d.h. in größeren Betrieben werden mehr Tiere beurteilt als in kleineren Betrieben. Entsprechend der Berechnungsformel von Cochran (1977) steigt die Anzahl der zu beurteilenden Tiere jedoch nicht linear an, sondern flacht bei steigenden Bestandsgrößen ab. Die Auswahl der Tiere soll dabei entweder im Melkstand (jede $\mathrm{n}^{\text {te }}$ Kuh), im Fressgitter (jede $\mathrm{n}^{\text {te }}$ Kuh) oder im Stall (aus allen Bereichen) erfolgen (Welfare Quality, 2012). In einer US-amerikanischen Studie wurden einige Tierwohlindikatoren wie z.B. Augenausfluss, Integumentschäden am Nacken sowie Sauberkeit an den Unterbeinen unabhängig von der Art der Stichprobenziehung akkurat erhoben. Jedoch wurden andere Tierwohlindikatoren (z.B. Lahmheit oder Sauberkeit am Euter) teilweise unterschätzt. Demzufolge sind insbesondere bei Tierwohlindikatoren mit niedrigen Prävalenzen höhere Stichprobenzahlen notwendig (Van Os et al., 2018).

Ein weiteres Problemfeld innerhalb des WQP sind die teilweise ungenügenden Inter-Beobachter-Reliabilitäten einzelner Tierwohlindikatoren. Insbesondere bei den Verhaltensbeobachtungen kann es zu unterschiedlichen Bewertungen derselben Stallsituation zwischen zwei oder mehr Beobachtern kommen, wie Studien zur Inter-Beobachter-Reliabilität bei der qualitativen Verhaltensbeobachtung (Bokkers et al., 2012) oder des Vermeidungsdistanztests (de Graaf et al., 2017a) 
zeigen. Auch die Bewertungen von Tierwohlindikatoren aus dem Bereich der Gesundheit wie z.B. Integumentschäden fallen zwischen verschiedenen Beobachtern z.T. unterschiedlich aus (Heath et al., 2014b). Umfangreiche Schulungen der Kontrolleure in der Anwendung des WQP sind demzufolge unerlässlich.

\subsection{Literaturverzeichnis}

Aerts, S., D. Lips, S. Spencer, E. Decuypere, and J. de Tavenier. 2006. A new framework for the assessment of animal welfare: Integrating existing knowledge from a practical ethics perspective. J. Agric. Environ. Ethics 19:67-76. https://doi.org/10.1007/s10806-005-4376-y.

Andreasen, S.N., P. Sandoe, and B. Forkman. 2014. Can animal-based welfare assessment be simplified? A comparison of the Welfare Quality ${ }^{\circledR}$ protocol for dairy cattle and the simpler and less time-consuming protocol developed by the Danish Cattle Federation. Anim. Welf. 23:81-94. https:// doi.org/ 10.7120/09627286.23.1.081.

Arbeitsgemeinschaft Deutscher Rinderzüchter (ADR). 2008. Jahresbericht 2008 - Das Wichtigste in Kürze. ADR.de. (Accessed 07. October 2017).

Arbeitsgemeinschaft Deutscher Rinderzüchter (ADR). 2016. Jahresbericht 2016 - Das Wichtigste in Kürze. ADR.de (Accessed 07. October 2017).

Armbrecht, L., C. Lambertz, D. Albers, and M. Gauly. 2018. Does access to pasture affect claw condition and health in dairy cows? Vet. Rec. 182:79-89. https://doi.org/10.1136/vr.104554.

Arnott, G., C.P. Ferris, and N.E. O'Connell. 2016. Review: welfare of dairy cows in continuously housed and pasture-based production systems. Animal. 11:261-273. https://doi.org/10.1017/S1751731116001336.

Barker, Z.E., K.A. Leach, H.R. Whay, N.J. Bell, and D.C.J. Main. 2010. Assessment of lameness prevalence and associated risk factors in dairy herds in England and Wales. J. Dairy Sci. 93: 932-941. https://doi.org/ 10.3168/jds. 2009-2309.

Barnouin, J., S. Bord, S. Bazin, and M. Chassagne. 2005. Dairy Management Practices Associated with Incidence Rate of Clinical Mastitis in Low Somatic Cell Score Herds in France. J. Dairy Sci. 88:3700-3709. https:// doi.org/10.3168/jds.S0022-0302(05)73056-3.

Bartussek, H. 1996. Tiergerechtheitsindex für Rinder TGI 35 L / 1996. Bayerische Anstalt für Landwirtschaft Gumpenstein. Bayerische Anstalt für Landwirtschaft-Verlag, Gumpenstein. 
Bauman, C.A., H.W. Barkema, J. Dubuc, G.P. Keefe, and D.F. Kelton. 2016. Identifying management and disease priorities of Canadian dairy industry stakeholders. J. Dairy. Sci. 99:1-10. https://doi.org/10.3168/jds.2016110 $\underline{57 .}$

Berge, A., and G. Vertenten. 2014. A field study to determine the prevalence, dairy herd management systems, and fresh cow clinical conditions associated with ketosis in western Eurpean dairy herds. J. Dairy Sci. 97: 21452154. https://doi.org/10.3168/jds.2013-7163.

Bicalho, R.C., and G. Oikonomou. 2013. Control and prevention of lameness associated with claw lesions in dairy cows. Livest. Sci. 156: 96-105. https:// doi.org/10.1016/..livsci.2013.06.007.

Black, R.A., R.J. Grant, and P.D. Krawczel. 2016. Short communication: Shortterm changes in stocking density did not alter meal characteristics of lactating Holstein dairy cattle. J. Dairy Sci. 99:6572-6577. https://doi.org/ 10.3168/jds.2015-9602.

Blokhuis, H.-J. 2008. International cooperation in animal welfare - The Welfare Quality ${ }^{\circledR}$ Project. Act. Vet. Scand. 50:10-15. https://doi.org/10.1186/17510147-50-S1-S10.

BMEL. 2017. Entwicklung der Milchleistung je Kuh. Bundesministerium für Ernährung und Landwirtschaft. https://www.bmel-statistik.de/ fileadmin/user_upload/monatsberichte/SJG-9310060-0000.pdf. (Zuletzt geprüft am: 15.12.2017).

Boe, K.E., and G. Faerevik. 2003. Grouping and social preferences in calves, heifers and cows. Appl. Anim. Beh. Sci. 80:175-190. https://doi.org/10. 1016/S0168-1591(02)00217-4.

Bokkers E.A.M., M. de Vries, I.C.M.A. Antonissen, and I.J.M. de Boer. 2012. Inter- and intra-observer reliability of experienced and inexperienced observers for the Qualitative Behaviour Assessment in dairy cattle. Anim. Welf. 21:307-318. https://doi.org/10.7120/09627286.21.3.307.

Botreau, R., M. Bonde, A. Butterworth, R. Percy, M.B.M. Bracke, J. Capdeville, and I. Veissier. 2007. Aggregation of measures to produce overall assessment of animal welfare. Part 1: A review of existing methods. Anim. Welf. 18:1179-1187. https://doi.org/10.1017/S1751731107000535.

Bradley, A.J. 2002. Bovine Mastitis: An evolving disease. The Vet. J. 164:166128. https://doi.org/https://doi.org/10.1053/tvjl.2002.0724.

Breen, J.E., M.J. Green, and A.J. Bradley. 2009. Quarter and cow risk factors associated with the occurrence of clinical mastitis in dairy cows in the 
United Kingdom. J. Dairy Sci. 92:2551-2561. https://doi.org/10.3168/jds. 2008-1369.

Brinkmann, J., H.-J. Herrmann, S. Ivemeyer, A. Pelzer und C. Winckler. 2016. Tierschutzindikatoren: Leitfaden für die Praxis - Rind. ISBN 978-3-945 088-34-0.

Broom, D. M., and A.F. Fraser. 2007. Domestic animal behaviour and welfare (4. Auflage). Centre for Agricultural Bioscience International, Wallingford.

Bruijnis, M.R.N., B. Beerda, H. Hogeveen, and E.N. Stassen. 2012. Foot disorders in dairy cattle: impact on cow and dairy farmer. Anim. Welf. 21:33-40. https://doi.org/10.7120/096272812X13345905673601.

Burow, E., P.T. Thomsen, T. Rousing, and J.T. Sorensen. 2013. Daily grazing time as a risk factor for alterations at the hock joint integument in dairy cows. Animal. 7:160-166. https://doi.org/10.1017/S1751731112001395.

Butterworth, A. 2009. Animal Welfare Indicators and their use in society. In: Smulders, F. J. M. and Algers, B. (Hrsg.): Welfare of production animals. Wageningen Academic Publishers, Wageningen, 371-389.

Butterworth, A., J.A. Mench, and N. Wielebnowski. 2011. Practical Strategies to Assess (and Improve) Welfare. In: Appleby, M. C. (Hrsg.): Animal welfare (2. Auflage). Centre for Agricultural Bioscience International, Wallingford, 200-214.

Canali, E., and E. Keeling. 2009. Welfare Quality ${ }^{\circledR}$ Project - from scientific research to on farm assessment of animal welfare. Ital. J. Anim. Sci., 8:900903. https://doi.org/10.4081/ijas.2009.s2.900.

Capdeville, J., and I. Veissier. 2001. A method of assessing welfare in loosehoused dairy cows at farm level, focusing on animal observations. Act. Agric. Scand. A, 51:62-68. https://doi.org/10.1080/090647001316923081.

Cha, E., J.A. Hertl, D. Bar, and Y.T. Gröhn. 2010. The cost of different types of lameness in dairy cows calculated by dynamic programming. Prev. Vet. Med. 97:1-8. https://doi.org/10.1016/.jprevetmed.2010.07.011.

Charlton, G.L., and S.M. Rutter. 2017. The behavior of housed dairy cattle with and without pasture access: a review. Appl. Anim. Beh. Sci. 192:2-9. http://dx.doi.org/10.1016/j.applanim.2017.05.015.

Chebel, R.C., P.R.B. Silva, M.I. Endres, M.A. Ballou, and K.L. Luchterland. 2016. Social stressors and their effects on immunity and health of periparturient dairy cows. J. Dairy Sci. 99:3217-3228. https://doi.org/10.3168/jds.201510369.

Cochran, W. G. 1977. Sampling Techniques. 3rd ed. Wiley \& Sons, New York, NY. 
Coignard, M., R. Guatteo, I. Veissier, A. de Boyer des Roches, L. Mounier, A. Lehébel, and N. Bareille. 2013. Description and factors of variation of the overall health score in French dairy cattle herds using the Welfare Quality ${ }^{\circledR}$ Assessment protocol. Prev. Vet. Med. 112:296-308. https://doi.org/ 10.1016/j.prevetmed.2013.07.018.

Cook, N.B., J.P. Hess, M.R. Foy, T.B. Bennett, and R.L. Brotzman. 2016. Management characteristics, lameness, and body injuries of dairy cattle housed in high-performance dairy herds in Wisconsin. J. Dairy Sci. 99:5879-5891. https://doi.org/10.3168/jds.2016-10956.

Dahlhoff, K. 2014. Beratung von milchviehhaltenden Betrieben auf der Basis von Verhaltens- und Erscheinungsparametern ihrer Milchkühe. Dissertation. Rheinische Friedrich-Wilhelms-Universität Bonn. http://hss.ulb.uni-bonn .de/ 2014/3657/3657.pdf.

De Boyer des Roches, A., I. Veissier, X. Boivin, E. Gilot-Fromont, and L. Mounier. 2016. A prospective exploration of farm, farmer, and animal characteristics in human-animal relationships: An epidemiological survey. J. Dairy Sci. 99:5573-5585. http://dx.doi.org/10.3168/jds.2015-10633.

De Graaf, S., B. Ampe, and F.A.M. Tuyttens. 2017a. Assessing dairy cow welfare at the beginning and end of the indoor period using the Welfare Quality ${ }^{\circledR}$ protocol. Anim. Welf. 26: 213-221. https://doi.org/10.7120/09627286.26. 2.213.

De Graaf, S., B. Ampe, C. Winckler, M. Radeski, L. Mounier, M.K. Kirchner, M.J. Haskell, F.J.C.M. van Eerdenburg, A. de Boyer des Roches, S.N. Andreasen, J. Bijttebier, L. Lauwers, W. Verbeke, and F.A.M. Tuyttens. 2017b Trained-user opinion about Welfare Quality measures and integrated scoring of dairy cattle welfare. J. Dairy Sci. 100:6376-6388. https://doi. org/10.3168/jds.2016-12255.

De Graaf, S., B. Ampe, S. Buijs, S.N. Andreasen, A. De Boyer des Roches, F.J.C.M. van Eerdenburg, M.J. Haskell, M.K. Kirchner, L. Mounier, M. Radeski, C. Winckler, J. Bijttebier, L. Lauwers, W. Verbeke, and F.A.M. Tuyttens. 2018. Sensitivity of the integrated Welfare Quality ${ }^{\circledR}$ scores to changing values of individual dairy cattle welfare measures. Anim. Welf. 27:157-166. https://doi.org/10.7120/09627286.27.2.157.

De Vries, A., H. Dechassa, and H. Hogeveen. 2016. Economic evaluation of stall stocking density of lactating dairy cows. J. Dairy Sci. 99:3448-3857. https:// doi.org/10.3168/jds.2015-10556. 
De Vries, M., E.A.M. Bokkers, C.G. van Reenen, B. Engel, G. van Schaik, T. Dijkstra, and I.J.M. de Boer. 2015. Housing and management factors associated with indicators of dairy cattle welfare. Prev. Vet. Med. 118:80-92. https://doi.org/10.1016/j.prevetmed. 2014.11.016.

De Vries, M., E.A.M. Bokkers, G. van Schaik, R. Botreau, B. Engel, T. Dijkstra, and I.J.M. de Boer. 2013. Evaluating results of the Welfare Quality multicriteria evaluation model for classification of dairy cattle welfare at the herd level. J. Dairy Sci. 96:6264-6273. http://dx.doi.org/10.3168/jds.2012-6129.

De Vries, M., E.A.M. Bokkers, T. Dijkstra, G. van Schaik, and I.J.M. de Boer. 2011. Invited review: Associations betwess variables of routine herd data and dairy cattle welfare indicators. J. Dairy Sci. 94:3213-3228. https://doi .org/ 10.3168/jds.2011-4169.

Deimel, I., A. Franz, M. Frentrup, M. von Meyer, A. Spiller, L. Theuvsen, J. Dettmer, M. Gauly, C. Salzborn, L. Schrader, and H. van den Weghe. 2010. Perspektiven für ein europäisches Tierschutzlabel. BLE Projekt- kennziffer 08HS010. http://download.ble.de/08HS010.pdf (Zuletzt geprüft am: 15. 12.2017).

Destatis. 2008. Land- und Forstwirtschaft, Fischerei Rinder- und Schweinebestand Statistisches Bundesamt. Fachserie 3 Reihe 4.1. https ://www.destatis.de/GPStatistik/servlets/MCRFileodeServlet/DEHeft_derivate_ 00004129/2030213079004.pdf (Accessed 07. October 2017).

Destatis. 2011. Land- und Forstwirtschaft, Fischerei Rinder- und Schweinebestand Statistisches Bundesamt. Fachserie 3 Reihe 4.1. https ://www.destatis.de/GPStatistik/servlets/MCRFileodeServlet/DEHeft_derivate_ 00004135/2030213109004.pdf (Accessed 07. October 2017).

Destatis. 2014. Land- und Forstwirtschaft, Fischerei Rinder- und Schweinebestand Statistisches Bundesamt. Fachserie 3 Reihe 4.1. https ://www. destatis.de/GPStatistik/servlets/MCRFileNodeServlet/DEHeft_derivate_ 00013372/2030213139004.pdf (Accessed 07. October 2017).

Destatis. 2017. Land- und Forstwirtschaft, Fischerei Rinder- und Schweinebestand Statistisches Bundesamt. Fachserie 3 Reihe 4.1. https ://www. destatis.de/GPStatistik/servlets/MCRFileNodeServlet/DEHeft_derivate_ 00032776/2030213169004.pdf (Accessed 07. October 2017).

Ermann, M., M. Fahlbusch, S. Kühl, B. Brümmer und B. Schulze-Ehlers. 2017. Der Markt für Milch und Milcherzeugnisse im Jahr 2016. Ger. J. Agric. Econ. 66:44-63.

Espejo, L.A., and M.I. Endres. 2007. Herd-Level Risk Factors for Lameness in High-Producing Holstein Cows Housed in Freestall Barns. J. Dariy Sci. 90:306-314. https://doi.org/10.3168/jds.S0022-0302(07)72631-0. 
Espejo, L.A., M.I. Endres, and J.A. Salfer. 2006. Prevalence of Lameness in HighProducing Holstein Cows Housed in Freestall Barns in Minnesota. J. Dairy Sci. 89:3052-3058. https://doi.org/ 10.3168/jds.S0022-0302(06)72579-6.

Estevez, I., I.L. Andersen, and E. Naevdal. 2007. Group size, density and social dynamics in farm animals. Appl. Anim. Beh. Sci. 103:185-204. https://doi. org/10.1016/j.applanim.2006.05.025.

Faulkner, P.M., and D.M. Weary. 2000. Reducing pain after dehorning in dairy calves. J. Dairy Sci. 83:2037-2041. https://doi.org/10.3168/jds.S0022-03 02(00)75084-3.

FAWC (1993): Report on Priorities for Animal Welfare Research and Development. Farm Animal Welfare Council. http://www.fawc.org.uk/pdf/old/animal-welfare-priorities-report-may1993.pdf (Zuletzt geprüft am: 15.12. 2017).

Fregonesi, J.A., C.B. Tucker, and D.M. Weary. 2007. Overstocking reduces lying time in dairy cows. J. Dairy Sci. 90:3349-3354. https://doi.org/10.3168 /jds.2006-794.

Gieseke, D., C. Lambertz., I. Traulsen, J. Krieter und M. Gauly. 2014. Beurteilung von Tiergerechtheit in der Milchviehhaltung - Evaluierung des Welfare Quality Protokolls. Züchtungskunde 86: 58-70. ISSN 0044-5401.

Goff, J.P. 2008. The monitoring, prevention and treatment of milk fever and subclinical hypocalcemia in dairy cows. The Vet. J. 176:50-57. https://doi. org/10.1016/j.tvil.2007.12.020.

Gottardo, F., E. Nalon, B. Contiero, S. Normando, P. Dalvit, and G. Cozzi. 2011. The dehorning of dairy calves: practices and opinions of 639 farmers. J. Dairy Sci. 94:5724-5734. https://doi.org/10.3168/jds.2011-4443.

Green, L.E., V.J. Hedges, Y.H. Schukken, R.W. Blowes, and A.J. Packington. 2002. The Impact of Clinical Lameness on the Milk Yield of Dairy Cows. J. Dairy Sci. 85:2250-2256. https://doi.org/10.3168/jds.2011-4443.

Haskell, M.J., L.J. Rennie, V.A. Bowell, M.J. Bell, and A.B. Lawrende. 2006. Housing System. Milk Production, and Zero-Grazing Effects on Lameness and Leg Injury in Dairy Cows. J. Dairy Sci. 89:4259-4266. https://doi.org/ 10.3168/jds.S0022-0302(06)72472-9.

Heath, C.A.E., W.J. Browne, S. Mullan, and D.C.J. Main. 2014b. Navigating the iceberg: reducing the number of parameters within the Welfare Quality ${ }^{\circledR}$ Assessment protocol for dairy cows. Animal. 8: 1978-1986. https://doi.org/ $\underline{10.1017 / S 1751731114002018 .}$ 
Heath, C.A.E., Y. Lin, S. Mullan, W.J. Browne, and D.C.J. Main. 2014a. Implementing Welfare Quality ${ }^{\circledR}$ in UK assurance schemes: evaluating the challenges. Anim. Welf. 23: 95-107. https://doi.org/10.7120/0962728623. 1.0 $\underline{95}$.

Heise, H. 2017. Tierwohl in der Nutztierhaltung: Eine Stakeholder-Analyse. Dissertation Georg-August-Universität Göttingen. https://ediss.uni-goettingen.de/bitstream/handle/11858/00-1735-0000-0023-3DFF-C/Dissertation 31.03.2017.pdf?sequence $=1$.

Hemsworth, P. H., J.L. Barnett, and G.J. Coleman. 2009. The integration of human-animal relations into animal welfare monitoring schemes. Anim. Welf. 18: 335-345.

Ingvartsen, K.L., R.J. Dewhurst, and N.C: Friggens. 2003. On the relationship between lactational performance and health: is it yield or metabolic imbalance that cause production diseases in dairy cattle? A position paper. Livest. Prod. Sci. 83:277-308. https://doi.org/10.1016/S0301-6226 (03)00 110-6.

Ivemeyer, S., U. Knierim, and S. Waiblinger. 2011. Effect of human-animal relationship and management on udder health in Swiss dairy herds. J. Dairy Sci. 94: 5890-5902. https://doi.org/10.3168/jds.2010-4048.

Jacobs, J.A., and J.M. Siegford. Invited review: The impact of automatic milking systems on dairy cow management, behavior, health, and welfare. J. Dairy sci. 95:2227-2247. https://doi.org/10.3168/jds.2011-4943.

Jensen, M.B., and K.L. Proudfoot. 2017. Effect of group size and health status on behavior and feed intake of multiparous dairy cows in early lactation. J. Dairy. Sci. 100:9759-9768. https://doi.org/10.3168/jds.2017-13035.

Johnsen, P. F., T. Johannesson, and P. Sandoe. 2001. Assessment of farm animal welfare at herd level - Many goals, many methods. Acta. Agric. Scan. A, 30:26-33. https://doi.org/10.1080/090647001316923027.

King, M.T.M., E.A. Pajor, S.J. LeBlanc, and T.J. DeVries. 2016. Associations of herd-level housing, management, and lameness prevalence with productivity and cow behavior in herds with automated milking systems. J. Dairy Sci. 99:9069-9079. http://dx.doi.org/10.3168/jds.2016-11329.

Knierim, U. 1998a. Wissenschaftliche Konzepte zur Beurteilung der Tiergerechtheit im englischsprachigen Raum. In: KTBL (Hrsg.): Beurteilung der Tiergerechheit von Haltungssystemen. Kuratorium für Technik und Bauwesen in der Landwirtschaft-Verlag. KTBL-Schrift 377, Darmstadt, 31-39. 
Knierim, U. 2002. Grundsätzliche ethologische Überlegungen zur Beurteilung der Tiergerechtheit bei Nutztieren. Dtsch. Tierärztl. Wochenschr. 109 (6): 261266.

Knierim, U., and C. Winckler. 2009. On-farm welfare assessement in cattle - Validity, reliability and feasibility issues and future perspectives with special regard to the Welfare Quality apply. Anim. Welf. 18:451-458. ISSN 0962$\underline{7286}$.

Koivula, M., E.A. Mätysaari, E. Negussie, and T. Serenius. 2005. Genetic and phenotypic relationships among milk yield and somatic cell count before and after clinical mastitis. J. Dairy Sci. 88:827-833. https://doi.org/10.31 68/jds.S0022-0302(05)72747-8.

Leach, K.A., H.R. Whay, C.M. Maggs, Z.E. Barker, E.S. Paul. A.K. Bell and D.C.J. Main. 2010. Working towards a reduction in cattle lameness: 1 . Understanding barriers to lameness control on dairy farms. Res. Vet. Sci. 89:311-317. https://doi.org/10.1016/j.rvsc.2010.02.014.

Lindena, T., R. Ellßel und H. Hansen. 2017. Steckbrief zur Tierhaltung in Deutschland - Milchkühe. Thünen-Institut. Braunschweig.https://www. thuenen.de/media/tithemenfelder/Nutztierhaltung_und_Aquakultur/Nutztierhaltung_und_Fleischproduktion/Milchviehhaltung/Steckbrief_Milchkuehe.pdf. (Zuletzt geprüft: 01.01.2018).

Lucy, M.C. 2001. ADSA Foundation Scholar Award. Reproductive Loss in HighProducing Dairy Cattle: Where will it end? J. Dairy Sci. 84:1277-1293. https ://doi.org/ 10.3168/jds.S0022-0302(01)70158-0.

M'hamdi, N., C. Darej, and R. Bouraoui. 2013. Animal welfare issues concerning procedures of calves dehorning. App. Sci. Report. 4.234-240. ISSN: 2311$\underline{0139 .}$

Main, D. C. J., C. Leeb, H.R. Whay, M. Hovi, and J. Webster. 2004. Bristol Welfare Assurance Programme. Animal based assessment tool for farm animal welfare certification. http://www.vetschool.bris.ac.uk/animalwelfare/images/BWAPweboverview.pdf (Zuletzt geprüft am: 15.12.2017).

Main, D. C. J., H.R. Whay, C. Leeb, and A.J.F. Webster. 2007. Formal animalbased welfare assessment in UK certification schemes. Anim. Welf. 16:233-236. ISSN 0962-7286.

Main, D. C. J., J.P. Kent, F. Wemelsfelder, E. Ofner, and F.A.M. Tuyttens. 2003. Applications for methods of on-farm welfare assessment. Anim. Welf. 12:523-528. ISSN 0962-7286. 
Manteca, X., A. Velarde, and B. Jones. 2009. Animal Welfare components. In: Smulders, F. J. M. and Algers, B. (Hrsg.): Welfare of production animals. Wageningen Academic Publishers, Wageningen, 61-77.

Miele, M., I. Veissier, A. Evans, and R. Botreau. 2011. Animal welfare - Establishing a dialogue between science and society. Anim. Welf. 20:103-117. ISSN 0962-7286.

Neves, R.C., B.M. Leno, T. Stokol, T.R. Overton, and J.A.A. McArt. 2017. Risk factors associated with postpartum subclinical hypocalcemia in dairy cows. J. Dairy Sci. 100:3796-3804. https://doi.org/10.3168/jds.2016-11970.

Nier, S., H. Bäuerle und C. Tamásy. 2013. Die deutsche Milchviehhaltung im Strukturwandel. ISPA-Mitteilungen 81, Vechta.

Nyman, A.-K., T. Ekman, U. Emanuelson, A.H. Gustafsson, K. Holtenius, K. Persson Waller and C. Hallén Sandgreen. 2007. Risk factors associated with the incidence of veterinary-treated clinical mastitis in Swedish dairy herds with a high milk yield and a low prevalence of subclinical mastitis. Prev. Vet. Med. 78:142-160. https://doi.org/10.1016/..prevetmed.2006.10. 002.

Olde Riekerink, R.G.M., H.W. Barkema, D.F. Kelton, and D.T. Scholl. 2008. Incidence rate of clinial mastitis on Canadian dairy farms. J. Dairy Sci. 91:1366-1377. https://doi.org/10.3168/jds.2007-0757.

Pelzer, A. 2007. Cows and more: Was die Kühe uns sagen! In: WGMEV (Hrsg.): Jahrestagung 2007, 36-38.

Plaizier, J.C., D-O- Krause, G.N. Gozho, and B.W. McBride. 2008. Subcacute ruminal acidosis in dairy cows: The physiological causes, incidence and consequences. The Vet. J. 176:21-31. https://doi.org/10.1016/j.tvjl.2007. 12.016.

Popescu, S., C. Borda, E.A. Diugan, M. Niculae, R. Stefan, and C.D. Sandru. 2014. The effect of the housing system on the welfare quality of dairy cows. Ital. J. Anim. Sci. 13:2940. https://doi.org/10.4081/ijas.2014.2940.

Raboisson, D., M. Moumié, and E. Maigné. 2014. Disease, reproductive performance and changes in milk production associated with subclinical ketosis in dairy cows: A meta-analysis and review. J. Dairy Sci. 97: 7547-7563. https://doi.org/10.3168/jds.2014-8237.

Raussi, S. 2003. Human-cattle interactions in group housing. Appl. Anim. Beh. Sci. 80:245-262. https://doi.org/10.1016/S0168-1591(02)00213-7.

Robbins, J.A., D.M. Weary, C.A. Schuppli, and M.A.G. von Keyserlingk. 2015. Stakeholder views on treating pain due to dehorning dairy calves. Anim. Welf. 24:399-406. https://doi.org/10.7120/09627286.24.4.399. 
Robbins, J.A., M. von Keyserlingk, D. Fraser, and D.M. Weary. 2016. Invited review: Farm size and animal welfare. J. Anim. Sci. 94:5439-5455. https:// doi.org/10.2527/jas.2016-0805.

Rousing, T., I.A. Jakobsen, J. Hindhede, I.C. Klaas, M. Bonde, and J.T. Sorensen. 2007. Evaluation of a welfare indicator protocol for assessing animal welfare in AMS herds - Researcher, production advisor and veterinary practitioner opinion. Anim. Welf. 16: 213-216. ISSN 0962-7286.

Ruegg, P.L., and J.C.F. Pantoja. 2013. Understanding and using somatic cell counts to improve milk quality. Irish. J. Agr. Food. Res. 52:101-117. http:// hdl.handle.net/11019/525.

Rushen, J. 2003. Changing concepts of farm animal welfare - Bridging the gap between applied and basic research. Appl. Anim. Beh. Sci. 81:199-214. https://doi.org/10.1016/S0168-1591(02)00281-2.

Rushen, J., and A.M. de Passillé. 2009. The scientific basis of animal welfare indicators. In: Smulders, F. J. M. and Algers, B. (Hrsg.): Welfare of production animals. Wageningen Academic Publishers, Wageningen, 391-415.

Sandoe, P., S.B. Christiansen, and M.C. Appleby. 2003. Farm animal welfare The interaction of ethical questions and animal welfare science. Anim. Welf. 12:469-478. ISSN 0962-7286.

Sanftleben, P., U. Knierim, H.-J. Herrmann, C. Müller, and E. von Borell. 2007. Kritische Kontrollpunkte (CCP) in der Milchrinderhaltung. Züchtungskunde 79 (5): 339-362. ISSN 0044-5401.

Schrader, L. 2009. Tierschutz und Tierhaltung in der Milchviehhaltung. Züchtungskunde 81(6):414-420. ISSN 0044-5401.

Sogstad, A.M., O. Osteras, and T. Fjeldaas. 2006. Bovine claw and limb disorders related to reproductive performance and production diseases. J. Dairy Sci. 89:2519-2528. https://doi.org/10.3168/jds.S0022-0302(06)72327-X.

Solano, L., H.W. Barkema, E.A. Pajor, S. Mason, S.J. LeBlanc, C. Zaffino Heyerhoff, C.G.R. Nash, D.B. Haley, E. Vasseur, D. Pellerin, J. Rushen, A.M. de Passillé, and K. Orsel. 2015. Prevalence of lameness and associated risk factors in Canadian Holstein-Friesian cows housed in freestall barns. J. Dairy Sci. 98:6978-6991. https://doi.org/10.3168/jds.2015-9652.

Stengärde, L., J. Hultgren, M. Travén, K. Holtenius, and U. Emanuelson. 2012. Risk factors for displaced abomasums or ketosis in Swedish dairy herds. Prev. Vet. Med. 103:280-286.10.1016/i.prevetmed.2011.09.005.

Stock, M.L., S.L. Baldridge, D. Giffin, and J.F. Coetzee. 2013. Bovine dehorning - assessing pain and providing analgesic. Vet. Clin. Food. Anim. 29:103133. http://dx.doi.org/10.1016/j.cvfa.2012.11.001. 
Stone, W.C. 2004. Nutritional approaches to minimize subacute ruminal acidosis and laminitis in dairy cattle. J. Dairy Sci. 87:13-26. https://doi.org/10.3168/ ids.S0022-0302(04)70057-0.

Sundrum, A., and R. Andersson. 1994. Tiergerechtheitsindex TGI. In: Sundrum, A., Andersson, R. und Postler, G. (Hrsg.): Tiergesundheitsindex 200 - Ein Leitfaden zur Beurteilung von Haltungssystemen. Köllen Druck + Verlag GmbH, Bonn, 20-29.

TSchG. 2017. Tierschutzgesetz. https://www.gesetze-im-internet.de/tierschg/ BJNR012770972.html. (Letzter Zugriff: 11.01.2018).

Van Os, J.M.C., C. Winckler, J. Trieb, S.V. Matarazzo, T.W. Lehenbauer, J.D. Champagne, and C.B. Tucker. 2018. Reliability of sampling strategies for measuring dairy cattle welfare on commercial farms. J. Dairy Sci. 101:1495-1504. https://doi.org/10.3168/jds.2017-13611.

Veissier, I., A. Aubert, and A. Boissy. 2012. Animal Welfare - A result of animal background and perception of its environment. Anim. Front., 2 (3):7-15. https://doi.org/10.2527/af.2012-0043.

Veissier, I., R. Botreau, and P. Perny. 2009. Scoring animal welfare - Difficulties and Welfare Quality ${ }^{\circledR}$ Solutions. In: Keeling, L. (Hrsg.): An Overview of the Development of the Welfare Quality ${ }^{\circledR}$ Project Assessment Systems. Welfare Quality ${ }^{\circledR}$, Lelystad, 15-32.

Ventura, B.A., M.A.G. von Keyserlingk, and D.M. Weary. 2015. Animal welfare concerns and values of stakeholders within the dairy industry. J. Agric. Environ. Ethics. 28:109-126. https://doi.org/10.1007/s10806-014-9523-x.

Vereinigte Informationssysteme Tierhaltung (VIT). 2016. Trends, Fakten, Zahlen. https://www.vit.de/fileadmin/Wir-sind-vit/Jahresberichte/vit-JB2016-ges amt.pdf. (Accessed 15.12.2017).

Von Keyserlingk, M.A.G., J. Rushen, A.M. de Passillé, and D.M. Weary. 2009. Invited review: the welfare of dairy cattle - key concepts and the role of science. J. Dairy Sci. 92:4101-4111. https://doi.org/10.3168/jds.2009-23 $\underline{26}$.

Wagner, K., J. Brinkmann, S. March, P. Hinterstoißer, S. Warnecke, M. Schüler, und H.M. Paulsen. 2018. Impact of daily grazing time on dairy cow welfare - results of the welfare quality ${ }^{\circledR}$ protocol. Animals. 8:1-11. https://doi.org/ 10.3390/ani8010001.

Waiblinger, S. 2012. Die Bedeutung der Veterinärmedizin für den Tierschutz. In: Grimm, H. und Otterstedt, C. (Hrsg.): Das Tier an sich - Disziplinenübergreifende Perspektiven für neue Wege im wissenschaftsbasierten Tierschutz. Vandenhoeck und Ruprecht Verlag, Göttingen, 172-197. 
Waiblinger, S., and C. Menke. 1999. Influence of herd size on human-cow relationships. Anthrozoos. 12:240-247. https://doi.org/10.2752/089279399787 $\underline{000156 .}$

Waiblinger, S., C. Menke, and G. Coleman. 2002. The relationship between attitudes, personal characteristics and behavior of stockpeople and subsequent behavior and production of dairy cows. Appl. Anim. Beh. Sci. 79:195-219. https://doi.org/10.1016/S0168-1591(02)00155-7.

Waiblinger, S., U. Knierim, and C. Winckler. 2001. The development of an epidemiologically based on-farm welfare assessment system for use with dairy cows. Acta Agric. Scand. A, 51 (30):73-77. https://doi.org/10.1080/09064 7001316923108.

Webster, A. J. F. 2003. Assessment of animal welfare at farm and group level Introduction and overview. Anim. Welf. 12:429-431. ISSN 0962-7286.

Webster, J. 2005. The assessment and implementation of animal welfare - Theory into practice. Rev. Sci. Tech. 24 (2):723-734. PMID:16358522.

Welfare Quality. 2012. Welfare Quality ${ }^{\circledR}$ Assessment protocol for cattle. Welfare Quality ${ }^{\circledR}$ Consortium, Lelystad, Netherlands. www.welfarequalitynetwork. net/network/45848/7/0/40 (Accessed 21. April 2018).

Whay, H. R. 2007. The journey to animal welfare improvement. Animal Welfare, 16:117-122. ISSN 0962-7286.

Widmar, N.O., C.J. Morgan, C.A. Wolf, E.A. Yeager, S.R. Dominick, and C.C. Croney. 2017. US resident perceptions of dairy cattle management practices. Agric. Sci. 8:645-656. https://doi.org/10.4236/as.2017.87049.

Winckler, C., J. Capdeville, G. Gebresenbet, B. Hörning, U. Roiha, M. Tosi, and S. Waiblinger. 2003. Selection of parameters for on-farm welfare-assessement protocols in cattle and buffalo. Anim. Welf. 12:619-624. ISSN 0962-7286.

Wissenschaftlicher Beirat Agrarpolitik beim BMEL (WBA). 2015. Wege zu einer gesellschaftlich akzeptierten Nutztierhaltung. Gutachten. Berlin.

Zapf, R., U. Schultheiß, W. Achilles, L. Schrader, U. Knierim, H.-J. Herrmann, J. Brinkmann, and C. Winckler. 2015. Indicators for on-farm self-assessment of animal welfare - Example: dairy cows. Landtechnik. 70:221-230. https:// doi.org/10.15150/lt.2015.2678. 


\section{KAPITEL 3}

\section{Effect of Herd Size on Animal Welfare Dairy Cattle}

Published:

D. Gieseke, C. Lambertz, and M. Gauly. 2018. Journal of Dairy Science. 101:7397-7411.

https://doi.org/10.3168/jds.2017-14232 


\section{Kapitel 3 Effect of Herd Size on Animal Welfare}

\section{Relationship between Herd Size and Measures of Animal Welfare on Dairy Cattle Farms with Freestall Housing in Germany}

Daniel Gieseke*, Christian Lambertz ${ }^{\dagger}$ and Matthias Gauly ${ }^{\star}$

* Department of Animal Sciences, Georg-August-University of Goettingen, Germany

+ Faculty of Science and Technology, Free University of Bolzano, Italy

\subsection{Abstract}

The objective of this study was to examine the association of herd size with animal welfare in dairy cattle herds. Therefore, 80 conventional dairy cattle farms were classified by the number of cows into 4 herd size classes, $C 1$ ( $<100$ cows), C2 (100-299 cows), C3 (300-499 cows), and C4 ( $\geq 500$ cows), and assessed using multiple animal-based measures of the Welfare Quality ${ }^{\circledR}$ Assessment protocol for dairy cattle. Data were recorded from April 2014 to September 2016 by an experienced single assessor in northern Germany. Each farm was visited 2 times at an interval of 6 months (summer period and winter period) to avoid seasonal effects on the outcome. The average herd size was $383 \pm 356$ Holstein-Friesian cows (range 45 to 1,629). Only farms with freestall (cubicle) housing and a maximum of 6 hours access to pasture per day were included in the study. Data were statistically analyzed using a generalized linear mixed model. None of the farms reached the highest overall rating of "excellent". The majority of the farms were classified as "enhanced" (30\%) or "acceptable" $(66 \%)$, and at 6 assessments farms were rated as "not classified" (4\%). Regarding single indicators, mean trough length per cow, percentage of cows with nasal discharge, and vulvar discharge increased with increasing herd size, whereas it was vice versa for displacements of cows. Percentage of lean cows, percentage of dirty lower legs, and duration of the process of lying down showed a curvilinear relationship with the number of cows per farm. Herd size was not associated with any other measures of the Welfare Quality ${ }^{\circledR}$ protocol. In conclusion, herd size effects were small, and consequently herd size cannot be considered as a feasible indicator 
of the on-farm animal welfare level. Housing conditions and management practices seem to have a greater effect on animal welfare than the number of dairy cows per farm.

Key words: animal welfare, herd size, dairy cow, welfare quality ${ }^{\circledR}$ protocol for cattle

\subsection{Introduction}

Over the last decades, milk production has intensified continuously in Europe. The number of dairy cattle farms in the member states of the European Union-10 (Belgium, Denmark, Germany, Ireland, Greece, France, Italy, Luxembourg, the Netherlands, and United Kingdom) decreased from 1,514,441 to 288,600 farms between 1983 and 2013 (-81\%). During this period the dairy cattle population declined by $31 \%$ from $25,143,828$ to $15,460,770$ animals, whereas average milk production remained stable (100 million tons). This indicates a significant improvement of the milk yield per cow (Eurostat, 2015), which might affect the welfare of dairy cows especially because of increasing health disorders (Coignard et al., 2014). Driven by this development, the average herd size in the stated European Union countries increased from 17 to 54 dairy cows per farm (Eurostat, 2015). A similar herd size development is noted on a global scale. Between 1970 and 2006, herd sizes increased from 19 to 120 animals in the United States (MacDonald et al., 2007), from 93 to 284 in Australia (Dairy Australia, 2015) and from 140 to 413 in New Zealand (Dairy New Zealand, 2014). During the same period, public awareness of animal welfare issues in livestock farming has increased (European Commission, 2016) and many consumers are concerned about the enduring intensification of livestock production (Spooner et al., 2014). The socalled factory farms are perceived as having serious animal health and welfare problems (Prickett et al., 2010; Vanhonacker and Verbeke, 2014). From the consumers' perspective, natural housing conditions are essential for animal welfare and these would only be provided in small-scale family farms (Krystallis et al., 2009; Spooner et al., 2014). Contrastingly, farmers do not seem to associate herd size with welfare-related issues. Performance and health of the animals are from their point of view more suitable indicators of animal welfare and can be maintained independent of the herd size (Vanhonacker et al., 2008; Sorensen and 
Fraser, 2010). However, little scientific evidence is available about whether there is a direct correlation between herd size and farm animal welfare status. Larger herds are associated with increasing stock per labor unit, increasing stocking density, and less access to pasture. Furthermore, better-trained staff, routine veterinary herd health visits, and monitoring systems are more likely in large herds (Beggs et al., 2015; Robbins et al., 2016). Numerous studies have considered herd size as an influencing factor for animal welfare issues with inconsistent results. For example, increasing herd size was reported as detrimental factor for lameness (Alban et al., 1995; de Vries et al., 2014) or mastitis (Lievaart et al., 2007; Archer et al., 2013), whereas in other studies a protective effect of increasing herd sizes was found for lameness (Dippel et al., 2009; Solano et al., 2015) or mastitis (Oleginni et al., 2001; Simensen et al., 2010). Others, however, did not observe any relationship between herd size and lameness (Barker et al., 2010; Fabian et al., 2014) or mastitis (Whitaker et al., 2004; Ivemeyer et al., 2011). Robbins et al. (2016) pointed out in their comprehensive review about farm size and animal welfare that study designs in the existing literature differ considerably and the definition of large and small herd sizes are country specific. Moreover, herd size has only been taken into account as a risk factor for single animal welfare indicators. Due to the multidimensional character of animal welfare, a holistic approach considering various health and behavior parameters is necessary to investigate the overall effect of herd size on animal welfare (Robbins et al., 2016). Therefore, the objective of this study was to examine the relationship between herd size and animal welfare and to analyze whether herd size could be used as an indicator of animal welfare at the herd level. A total of 80 conventional dairy cattle farms with different herd sizes (small: <100; medium: 100-299; large: 300-499; very large: $\geq 500$ cows) were assessed using multiple animal-based measures of the Welfare Quality ${ }^{\circledR}$ Assessment protocol (WQP) for dairy cattle (Welfare Quality, 2012).

\subsection{Material and Methods}

\section{Study Design}

The data collection was conducted from April 2014 to September 2016 by a single assessor on 80 conventional dairy farms located in northern Germany. Each farm was visited 2 times at an interval of 6 months (summer period and winter period) 
to avoid seasonal effects on the animal welfare assessment. At both visits the animal welfare was assessed using the WQP. This is a standardized indicator system for on-farm animal welfare assessment. It focuses mainly on animalbased measures, which directly reflect the actual welfare state of the animals. More than 30 animal welfare indicators covering aspects of feeding, housing, health and behavior were measured and aggregated to 12 welfare criteria and 4 welfare principles (Welfare Quality, 2012). Finally, farms were assigned to 1 of 4 overall welfare categories, representing an "excellent", "enhanced" or "acceptable" animal welfare state. In cases where minimum requirements could not be achieved, the farms were rated as "not classified". The assessor was trained intensively by a member of the Welfare Quality ${ }^{\circledR}$ Network (Christoph Winckler, University of Natural Resources and Life Sciences, Vienna, Austria) to ensure the correct application of the dairy-cattle-specific indicators of the WQP. The official four-day training course at the University of Natural Resources and Life Sciences in Vienna (Austria) consisted of theoretical exercises with photos and videos as well as practical applications of the WQP on different dairy cattle farms. Data collection of this study was conducted by this assessor only.

\section{Farm Selection}

Farm acquisition was organized with the support of different agricultural stakeholders (e.g., chamber of agriculture, milk recording association, and research facilities). For participation in the study, some specific requirements had to be fulfilled to guarantee the comparability of the housing environment. All lactating dairy cows in the sample had to be kept in loose housing barns with deep bedded or rubber mat-equipped cubicles. The dominant breed was Holstein Friesian so that genetic effects could be excluded. Farms with access to pasture for more than 6 hours per day were omitted from the study because this resource-based indicator has a high weighting within the aggregation system of the WQP and an inclusion would lead to a substantial confounding effect. Nine farms provided access to pasture for less than six hours per day without significant feed intake ("outdoor loafing areas"). There were no other limitations regarding housing conditions, milking techniques, or feeding systems (for further characterizations of the farms see Table 3.3) The 80 dairy cattle farms were classified based on the 
herd sizes according to the classification of the federal statistical office in Germany (Destatis, 2017). The first class had $<100$ dairy cows (C1), the second 100 to 299 dairy cows (C2), the third 300 to 499 dairy cows (C3) and the fourth $\geq 500$ cows (C4). Each class consisted of 20 farms. Maximum group sizes were documented, defined as the maximum number of dairy cows within a lactation group. These were considered, because associations between single animal welfare indicators and group size, rather than herd size, were assumed (e.g., agonistic interactions).

Table 3.3: Characteristics (farm data, performance data and housing conditions) of 80 dairy farms classified by herd size into C1 = $<100$ cows, C2 =100-299 cows, C3 = 300-499 cows, or C4 = $\geq 500$ cows.

\begin{tabular}{|c|c|c|c|c|c|c|}
\hline \multirow{2}{*}{\multicolumn{2}{|c|}{$\begin{array}{c}\text { Farm charac- } \\
\text { teristics }^{1}\end{array}$}} & \multirow[b]{2}{*}{ Parameter } & \multicolumn{4}{|c|}{ Herd Size Class } \\
\hline & & & C1 & $\mathrm{C} 2$ & C3 & C4 \\
\hline \multirow{6}{*}{ 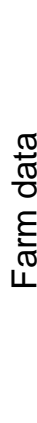 } & \multirow{2}{*}{$\begin{array}{l}\text { Herd } \\
\text { size }\end{array}$} & Mean + SD & $74+14$ & $185+$ & $381+$ & 77 \\
\hline & & Range & $45-99$ & $102-284$ & $304-493$ & $548-1629$ \\
\hline & \multirow{2}{*}{$\begin{array}{l}\text { Group } \\
\text { size }\end{array}$} & Mean \pm SD & $60 \pm 10$ & $85 \pm 28$ & $118 \pm 39$ & $147 \pm 50$ \\
\hline & & Range & $38-77$ & $32-134$ & $48-188$ & $84-267$ \\
\hline & \multirow{2}{*}{$\begin{array}{l}\text { Hectares/ } \\
\text { cow }\end{array}$} & Mean \pm SD & $1.5 \pm 0.9$ & $3.0 \pm 3.5$ & $3.0 \pm 2.3$ & $2.0 \pm 1.5$ \\
\hline & & Range & $0.7-4.6$ & $0.3-14.3$ & $0.4-7.6$ & $0.4-6.2$ \\
\hline \multirow{6}{*}{$\begin{array}{l}\frac{\pi}{\pi} \\
\frac{\pi}{0} \\
\mathbb{0} \\
\frac{0}{\pi} \\
\frac{\pi}{0} \\
\frac{0}{0} \\
\frac{1}{0} \\
0\end{array}$} & \multirow[t]{2}{*}{ Fat, \% } & Mean \pm SD & $4.04 \pm 0.19$ & $4.03 \pm 0.16$ & $3.95 \pm 0.21$ & $3.92 \pm 0.18$ \\
\hline & & Range & $3.60-4.40$ & $3.66-4.46$ & $3.65-4.60$ & $3.50-4.42$ \\
\hline & \multirow[t]{2}{*}{ Protein, \% } & Mean \pm SD & $3.34 \pm 0.08$ & $3.38 \pm 0.07$ & $3.38 \pm 0.07$ & $3.36 \pm 0.10$ \\
\hline & & Range & $3.15-3.53$ & $3.21-3.50$ & $3.19-3.58$ & $3.13-3.50$ \\
\hline & \multirow[t]{2}{*}{$\mathrm{ECM}, \mathrm{kg}$} & Mean \pm SD & $9464 \pm 1024$ & $9588 \pm 1158$ & $10127 \pm 716$ & $10027 \pm 771$ \\
\hline & & Range & $7091-11046$ & $6434-11761$ & $8637-11792$ & $8343-11736$ \\
\hline \multirow{8}{*}{ 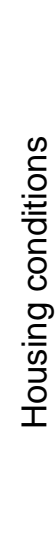 } & \multirow[t]{2}{*}{ Cubicles } & Deep bedded & $65 \% \quad(13)$ & $70 \% \quad(14)$ & $90 \% \quad(18)$ & $70 \% \quad(14)$ \\
\hline & & Rubber mat & $35 \% \quad(7)$ & $30 \% \quad(6)$ & $10 \% \quad(2)$ & $30 \% \quad(6)$ \\
\hline & \multirow[t]{2}{*}{ Floors } & Plain & $5 \% \quad(1)$ & $60 \% \quad(12)$ & $75 \% \quad(15)$ & $75 \% \quad(15)$ \\
\hline & & Slatted & $95 \% \quad(19)$ & $40 \% \quad(8)$ & $25 \% \quad(5)$ & $25 \% \quad(5)$ \\
\hline & \multirow[t]{2}{*}{ Feeding } & Feed rack & $95 \% \quad(19)$ & $45 \% \quad(9)$ & $40 \% \quad(8)$ & $20 \% \quad(4)$ \\
\hline & & Neck tube & $5 \% \quad(1)$ & $55 \% \quad(11)$ & $60 \% \quad(12)$ & $80 \% \quad(16)$ \\
\hline & \multirow[t]{2}{*}{ Insulation } & Insulated & $80 \% \quad(16)$ & $35 \% \quad(7)$ & $40 \% \quad(8)$ & $35 \% \quad(7)$ \\
\hline & & Not insulated & $20 \% \quad(4)$ & $65 \% \quad(13)$ & $60 \% \quad(12)$ & $65 \% \quad(13)$ \\
\hline
\end{tabular}

${ }^{1} \mathrm{ECM}=$ energy corrected milk 


\section{Data Collection}

Animal welfare assessments were conducted following the instructions of the WQP for dairy cattle (Welfare Quality, 2012). Minor modifications were made for practical or statistical reasons (e.g., non-lactating cows were excluded). Modified animal welfare indicators and assessment methods are described in Table 3.4. The farm visits usually started at 8 am $( \pm 1 \mathrm{~h})$ after morning milking and lasted, depending on herd size, 6 to 13 hours. Data collection was performed at each farm in a fixed order. At the beginning, the human-animal-relationship was assessed using the avoidance-distance-test at the feeding rack (ADF). Subsequently the Qualitative Behavior Assessment (QBA) was executed for 25 minutes to evaluate the emotional state of the herd. Behavioral observations took place in up to 12 different segments of the barn (with a maximum of 25 dairy cows per segment). Lying behavior, agonistic behavior, and coughing were recorded using a continuous behavior sampling (approx. 150-180 minutes).

The clinical scoring of individual dairy cows was carried out in a sample according to group size, if animals were kept in different groups. All measures were recorded in the same sample of animals (body condition, cleanliness, lameness, integument alterations, discharge, diarrhea, hampered respiration). Depending of the herd size, a sample of 32 to 102 cows were assessed at each farm visit. In total, 10,758 individual animals were observed during the 2-year data collection period (5,405 in summer and 5,353 in winter season). Finally, resource-based measures (water provision, cleanliness, functionality) were assessed in the barn and management-based measures (mortality, dystocia, downer cows, and dehorning practice) as well as milk-recording data (somatic cell count) were gathered during a farmer interview. Five farms were excluded, because herd sizes changed considerably during data collection period and two farms because the housing system changed. Datasets of the 80 dairy cattle farms were complete for all measures of the WQP. In addition to the indicators of the WQP, farm characteristics such as design of barn (insulated, not insulated), cubicles (deep bedded, rubber mat), floor (slatted, plain), or feeding place (neck tube, feed rack) were recorded. 
Table 3.4: Data collected for the assessment of the animal welfare level of dairy cows using the Welfare Quality ${ }^{\circledR}$ protocol (modified after Coignard et al., 2013; modifications of the WQP are highlighted in bold).

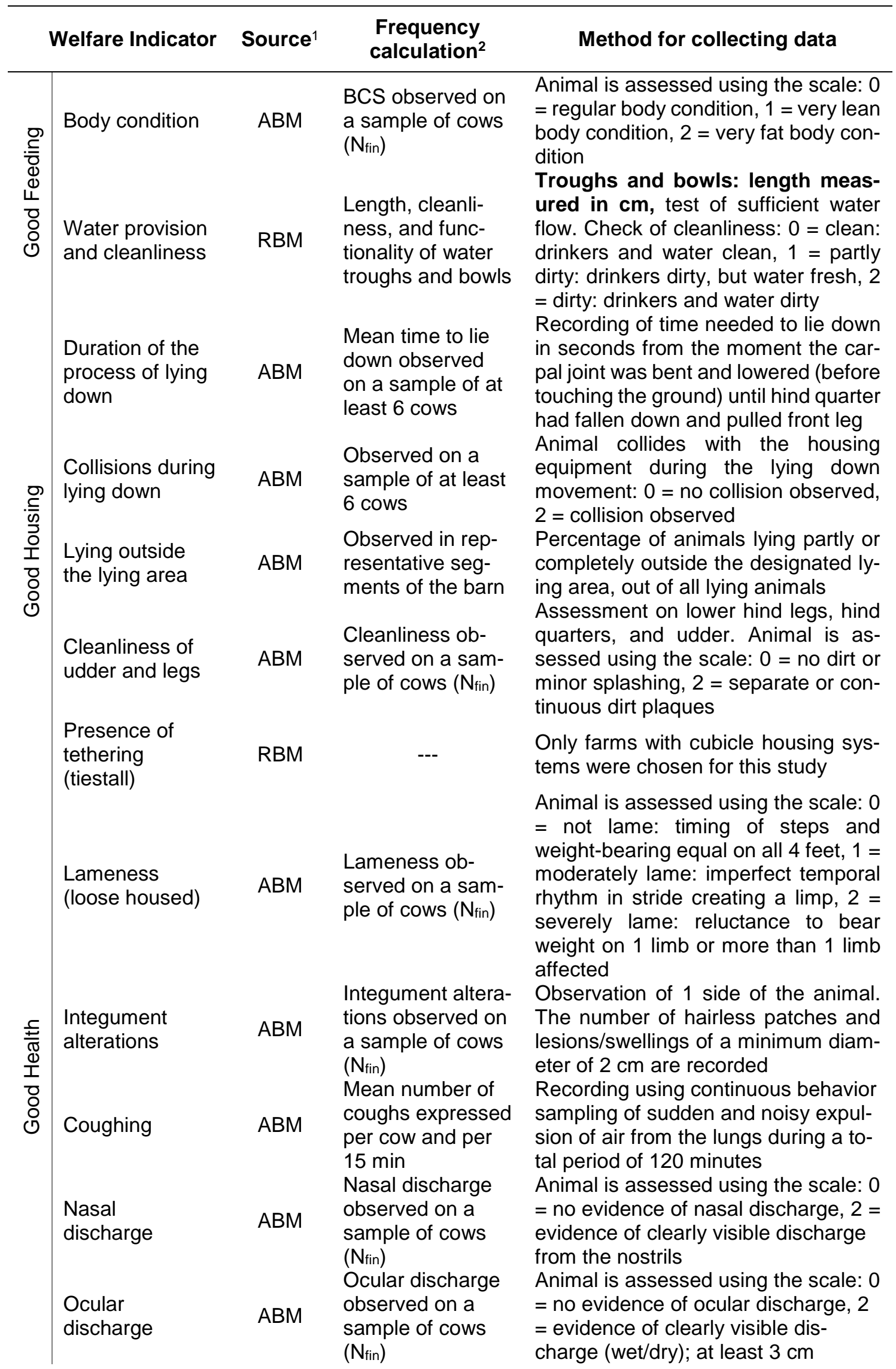




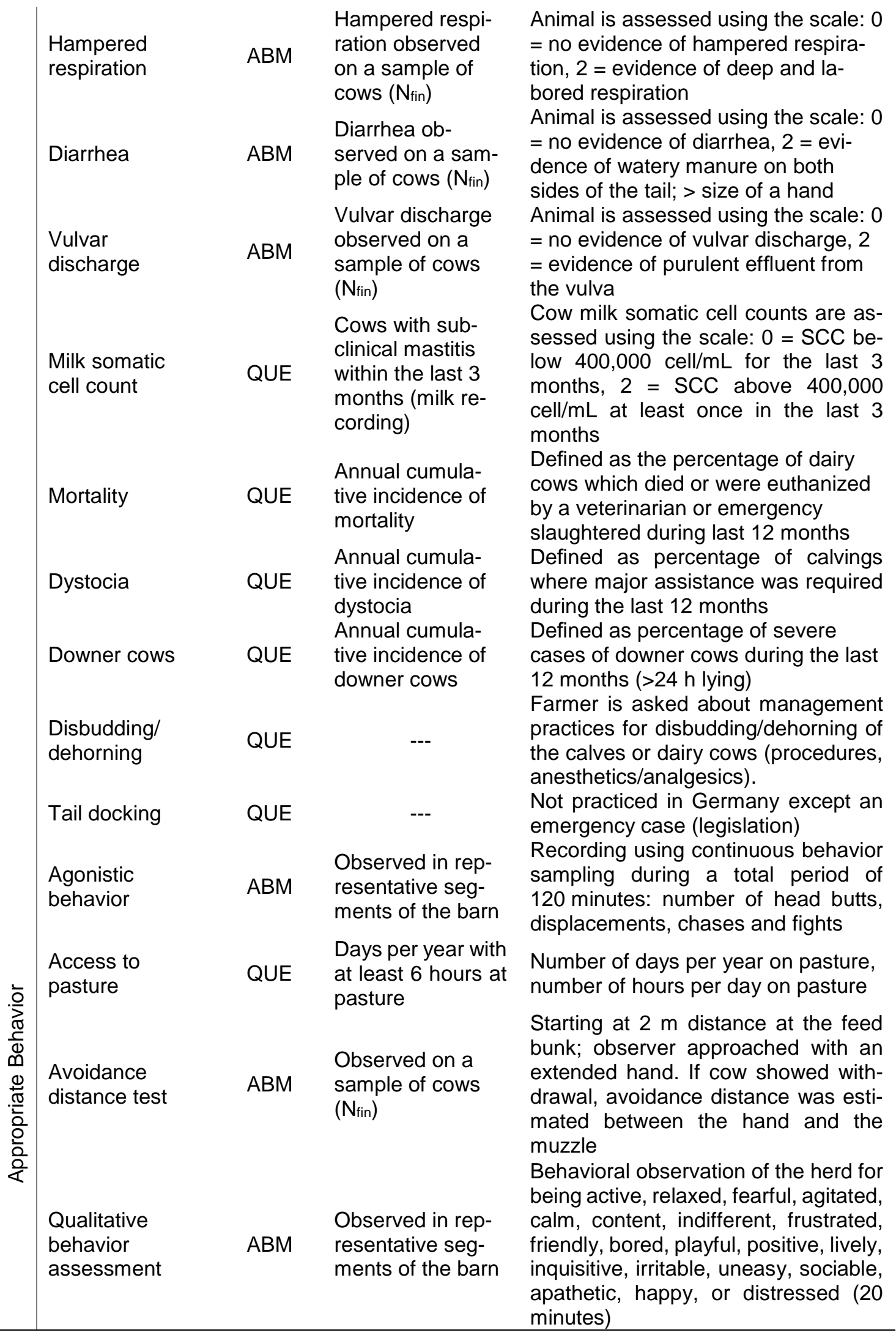

${ }^{1} \mathrm{ABM}=$ animal-based measure; RBM = resource-based measure; $\mathrm{QUE}$ = questionnaire.

${ }^{2} \mathrm{~N}_{\text {fin }}=$ sample size according to Welfare Quality (2012). 


\section{Statistical Analysis}

Single indicators were summarized to criteria, principles, and overall score using decision trees, I-spline-functions, and Choquet-integrals as described in the WQP. Data were checked before analysis for normal distribution using the test of Shapiro-Wilk $(p<0.05)$. If normal distribution was not given, data were log-, sqrtor arcsin-transformed. For parameters without normal distribution after transformation, $\mathrm{p}$-values were calculated assuming a Poisson distribution.

All statistical analyses were computed with SAS, version 9.4 (Statistical Analysis Systems, Cary, NC, USA) using the GLIMMIX procedure. The following linear mixed effects model was used to analyze principles, criteria, and indicators:

$$
Y_{i j k l}=\mu+a_{i}+b_{j}+c_{i j}+d_{k}+e_{l}+\varepsilon_{i j k l m}
$$

with $Y_{\mathrm{ijkl}}=$ observed value of principles/criteria/indicators, $\mu=$ overall average of sample, $a_{i}=$ fixed effect of herd size $i(C 1, C 2, C 3, C 4), b_{j}=$ fixed effect of season $\mathrm{j}$ (summer, winter), $\mathrm{c}_{i j}=$ interaction between herd size i and season $\mathrm{j}, \mathrm{d}_{\mathrm{k}}=$ covariate of maximum group size $\mathrm{k}$ (continuous), $\mathrm{e}_{\mathrm{I}}=$ random effect of the farm $\mathrm{I}$, and $\varepsilon_{\mathrm{ijk} / m}=$ residual error. Farm was defined as the statistical unit and results were considered as statistically significant at $p<0.05$. Differences between herd size classes were assessed by applying the Tukey-Kramer test. Scores are presented as least square means (LSM) and pooled standard errors (PSE). Additionally, a chi-squared test of independence (Fisher's exact test) followed by pair-wise comparisons with Bonferroni-Holm correction were performed at the level of the overall classification to test for possible differences between herd size classes.

\subsection{Results}

\section{Overall Assessment}

Table 3.5 illustrates that none of the farms reached the highest rating of "excellent". The majority of the farms were classified as "enhanced" (30\%) or "acceptable" $(66 \%)$. At 6 assessments ( 3 in summer, 3 in winter), the minimum welfare requirements of the WQP were not met and farms were consequently rated as "not classified" (4\%). Most of the dairy farms achieved the same overall scores in summer and winter season (68\%), whereas 8 farms were rated better in summer (10\%) and 18 farms better in winter (22\%). Herd size classes C1 and C3 achieved 
higher overall scores in winter, whereas $\mathrm{C} 2$ and $\mathrm{C} 4$ were rated better in summer season. No significant effect of the season was found ( $p>0.05$ ). Pair-wise comparisons revealed that $\mathrm{C} 2$ achieved significantly lower overall scores in winter compared to the classes with larger herds (C3 and $\mathrm{C} 4$ ). In contrast, overall scores of the herd size classes did not differ in the summer season $(p>0.05)$.

Table 3.5: Overall classification of the Welfare Quality ${ }^{\circledR}$ assessments in season 1 (summer) and season 2 (winter) for dairy farms with $<100$ cows (C1), 100-299 cows (C2), 300-499 cows (C3) or $\geq 500$ cows (C4) and $x^{2}$ test of independence (Fisher's exact test; $n=20$; highlighted $p$-values are significant $(p<0.05))^{1}$.

\begin{tabular}{|c|c|c|c|c|c|c|c|c|c|c|c|}
\hline \multirow{3}{*}{$\begin{array}{l}\text { Overall } \\
\text { Classification }\end{array}$} & \multicolumn{8}{|c|}{ Herd size class } & \multirow{2}{*}{\multicolumn{3}{|c|}{$\begin{array}{l}\mathrm{x}^{2} \text { test comparing } \\
\text { herd size classes }\end{array}$}} \\
\hline & \multicolumn{2}{|c|}{ C1 } & \multicolumn{2}{|c|}{ C2 } & \multicolumn{2}{|c|}{ C3 } & \multicolumn{2}{|c|}{ C4 } & & & \\
\hline & $S$ & W & $S$ & W & $S$ & W & $S$ & W & S & W & $\mathrm{T}$ \\
\hline Excellent & 0 & 0 & 0 & 0 & 0 & 0 & 0 & 0 & 0.13 & $<0.01$ & $<0.01$ \\
\hline Enhanced & 3 & 7 & 3 & 1 & 5 & 12 & 9 & 8 & & & \\
\hline Acceptable & 15 & 13 & 17 & 16 & 14 & 8 & 11 & 12 & & & \\
\hline Not classified & 2 & 0 & 0 & 3 & 1 & 0 & 0 & 0 & & & \\
\hline
\end{tabular}

$\mathrm{X}^{2}$ test comparing summer to winter assessment within herd size classes
0.17
0.22
0.05
1.00

${ }^{1} \mathrm{~S}=$ summer; $\mathrm{W}=$ winter $; \mathrm{T}=$ total

\section{Principles}

Results from the level of principles in summer and winter season are illustrated in Table 3.6. For the principle "good feeding" an effect of herd size $(p<0.01)$ and herd size and season interaction was observed $(p<0.01)$. Farms of class C2 achieved lower scores in summer compared with the larger farms of classes C3 in winter and $\mathrm{C} 4$ in summer. The mean principle score of $\mathrm{C} 2$ in winter was significantly lower than the scores of $\mathrm{C} 3$ and $\mathrm{C} 4$ at both assessments. Additionally, a significant effect of group size was found $(p<0.01)$. The larger the group size, the lower was the principle score "good feeding". Scores of the principle "good housing" were not affected by class, season, or the interaction ( $p>0.05$ ). The principle "good health" (22.6 \pm 1.1$)$ was the one with the lowest average scores, compared with "good feeding" (37.4 \pm 5.3 ), "good housing" (60.0 \pm 1.8$)$, and "appropriate 
behavior" (38.2 \pm 1.1$)$. Results of this principle were not affected by herd size $(p>0.05)$, but in all classes values were higher in winter $(24.0 \pm 0.6)$ than in summer $(21.1 \pm 0.6 ; p<0.01)$. For the principle "appropriate behavior", neither of the tested factors had an effect $(p>0.05)$.

\section{Criteria}

As presented in Table 3.6, herd size classes differed in the criterion "absence of prolonged hunger" $(p<0.05)$. Averaged over both seasons, C2 received a significantly lower score $(38.8 \pm 2.9)$ compared with C3 (51.4 \pm 2.9$)$ and C4 (52.0 \pm 3.3), respectively. The scores of $\mathrm{C} 1(41.4 \pm 3.3)$ did not differ from the scores of the other herd size classes $(p>0.05)$. For the criterion "absence of prolonged thirst", an effect of herd size $(p<0.05)$ and the interaction of herd size and season was found $(p<0.01)$. Scores increased from summer to winter in $C 1$ and $C 3$, whereas they decreased in both other classes. Lowest scores were found in C2 and highest in C4. Additionally, a significant effect of group size was found $(p<0.01)$. The larger the group size, the lower was the score of the criterion "absence of prolonged thirst". Within the criterion "comfort around resting", C1 and C3 were rated better in winter compared with summer, whereas no seasonal difference was found for $\mathrm{C} 2$ and $\mathrm{C} 4$ ( $\mathrm{p}<0.05$, interaction effect).

A significant effect of the season was determined for the criterion "absence of injuries" ( $p<0.01)$. In each herd size category, results were better in winter (29.7 $\pm 1.3)$ than in summer $(21.9 \pm 1.3)$. The prevalence of diseases within the dairy farms was not influenced by the examined effects $(p>0.05)$. Within the criterion "expression of social behaviors", social interactions were at a comparable level between the 4 herd size classes ( $p>0.05$ ). For the criterion "human-animal-relationship", no influence of the herd size, but an effect of the season was found $(p<0.05)$. Averaged over both farm visits the scores in winter were higher compared to summer, particularly in $\mathrm{C} 3$ and $\mathrm{C} 4$. The results of the qualitative behavior assessment, more specifically the related criterion "positive emotional state" was influenced by the interaction between herd size and season $(p<0.01)$. Whereas the classes C1 (74.5 \pm 3.4 points), C2 (78.5 \pm 3.0 points) and C4 (78.1 \pm 3.4 points) performed better in winter season, $\mathrm{C} 3$ (77.8 \pm 3.0 points) showed a higher amount of positive emotions in summer season. 


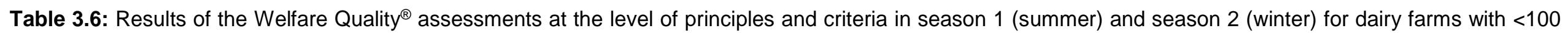

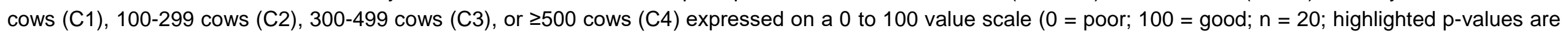
significant $(p<0.05))^{1}$.

\begin{tabular}{|c|c|c|c|c|c|c|c|c|c|c|c|c|c|}
\hline \multirow{3}{*}{ Welfare principle/criterion } & \multicolumn{8}{|c|}{ Herd size class } & \multirow{3}{*}{ PSE } & \multicolumn{4}{|c|}{ P-value } \\
\hline & \multicolumn{2}{|c|}{ C1 } & \multicolumn{2}{|c|}{$\mathrm{C} 2$} & \multicolumn{2}{|c|}{ C3 } & \multicolumn{2}{|c|}{ C4 } & & \multirow{2}{*}{$\begin{array}{l}\text { Herd size } \\
\quad(H)\end{array}$} & \multirow{2}{*}{$\begin{array}{l}\text { Season } \\
\text { (S) }\end{array}$} & \multirow{2}{*}{$\begin{array}{c}\text { Interaction } \\
(\mathrm{H} \times \mathrm{S})\end{array}$} & \multirow{2}{*}{$\begin{array}{c}\text { Group size } \\
\text { (G) }\end{array}$} \\
\hline & $\mathrm{S}$ & W & $\mathrm{S}$ & W & $\mathrm{S}$ & W & $\mathrm{S}$ & W & & & & & \\
\hline Good Feeding & 30.9 & 33.5 & 24.8 & 20.2 & 45.0 & 48.5 & 51.0 & 45.2 & 5.7 & $<0.01$ & 0.10 & $<0.01$ & $<0.01$ \\
\hline Absence of prolonged hunger & 40.5 & 42.4 & 40.1 & 37.4 & 49.2 & 53.6 & 54.9 & 49.0 & 3.7 & 0.02 & 0.70 & 0.23 & 0.20 \\
\hline Absence of prolonged thirst & 45.0 & 47.8 & 33.3 & 30.4 & 58.4 & 66.6 & 68.2 & 61.3 & 10.2 & 0.01 & 0.53 & $<0.01$ & $<0.01$ \\
\hline Good Housing & 55.0 & 58.9 & 60.2 & 60.1 & 62.3 & 64.2 & 59.9 & 59.8 & 2.0 & 0.11 & 0.24 & 0.55 & 0.06 \\
\hline Comfort around resting & 28.5 & 34.7 & 36.8 & 36.6 & 40.1 & 43.1 & 36.4 & 36.1 & 3.2 & 0.08 & 0.01 & 0.02 & 0.15 \\
\hline Ease of movement & 100.0 & 100.0 & 100.0 & 100.0 & 100.0 & 100.0 & 100.0 & 100.0 & 0.0 & NT & NT & NT & NT \\
\hline Good Health & 21.1 & 23.1 & 20.7 & 23.3 & 21.8 & 25.3 & 20.9 & 24.4 & 1.3 & 0.75 & $<0.01$ & 0.84 & 0.97 \\
\hline Absence of injuries & 21.2 & 26.3 & 18.6 & 29.0 & 24.9 & 31.9 & 22.9 & 31.4 & 2.7 & 0.31 & $<0.01$ & 0.78 & 0.22 \\
\hline Absence of diseases & 25.1 & 24.3 & 25.1 & 22.8 & 23.6 & 22.5 & 20.5 & 20.7 & 1.7 & 0.37 & 0.21 & 0.71 & 0.19 \\
\hline Absence of pain & 37.8 & 32.3 & 38.3 & 31.6 & 36.5 & 37.9 & 42.6 & 43.6 & 3.4 & 0.54 & $<0.01$ & $<0.01$ & 0.60 \\
\hline Appropriate Behavior & 36.3 & 37.9 & 39.1 & 39.6 & 40.4 & 36.8 & 38.1 & 37.2 & 1.2 & 0.39 & 0.54 & 0.27 & 0.85 \\
\hline Expression of social behaviors & 77.0 & 82.2 & 85.7 & 84.6 & 87.8 & 85.3 & 90.0 & 86.0 & 2.5 & 0.08 & 0.73 & 0.12 & 0.20 \\
\hline Expression of other behaviors & 0.0 & 0.0 & 0.0 & 0.0 & 0.0 & 0.0 & 0.0 & 0.0 & 0.0 & NT & NT & NT & NT \\
\hline Human-animal relationship & 75.7 & 75.6 & 76.8 & 76.1 & 75.3 & 71.0 & 72.9 & 67.9 & 2.8 & 0.46 & 0.03 & 0.31 & 0.41 \\
\hline Positive emotional state & 72.6 & 76.3 & 78.0 & 79.0 & 83.8 & 71.9 & 77.7 & 78.5 & 3.5 & 0.76 & 0.18 & $<0.01$ & 0.53 \\
\hline
\end{tabular}

${ }^{1} \mathrm{~S}=$ summer; $\mathrm{W}=$ winter; $\mathrm{PSE}=$ pooled standard error; $\mathrm{NT}=$ not tested. 


\section{Indicators}

Results at indicator level are described in Table 3.7. For the indicator "percentage of very lean cows", effects of herd size $(p<0.05)$ and the herd size $x$ season interaction were found $(p<0.01)$. The smaller farms of class $C 1(13.9 \pm 1.6 \%)$ and C2 $(16.0 \pm 1.4 \%)$ had a higher amount of lean cows than the larger farms of class C3 $(10.3 \pm 1.4 \%)$ and C4 (10.5 $\pm 1.6 \%)$. A difference between the herd size classes could only be confirmed for C2 in winter, compared with C3 in winter and C4 in summer $(p<0.05)$. Trough length per animal rose with increasing herd size $(p<0.01)$. Over both seasons, $C 3(7.8 \pm 0.6 \mathrm{~cm})$ and $C 4(8.0 \pm 0.7 \mathrm{~cm})$ provided more water surface per animal compared with $\mathrm{C} 1(4.2 \pm 0.6 \mathrm{~cm})$ and C2 $(5.0 \pm$ $0.6 \mathrm{~cm}$ ). Moreover, a significant effect of group size and season was determined. The larger the group size, the lower was the trough length per animal $(p<0.01)$. Dairy cows had more water surface available in summer season $(6.4 \pm 0.3 \mathrm{~cm})$, compared with the winter months $(6.0 \pm 0.3 \mathrm{~cm} ; \mathrm{p}<0.05)$.

An influence of the herd size was found for the indicator "duration of the process of lying down in a stall" $(p<0.05)$. On average, dairy cows of the smallest class C1 needed more time to lie down $(6.0 \pm 0.1 \mathrm{sec})$, compared with the animals of the class C3 with 300 to 499 cows $(5.5 \pm 0.1 \mathrm{sec})$. The indicator "percentage of cows lying outside cubicles" was influenced by season. The scores of all herd size classes were lower in winter than in summer $(p<0.05)$. Furthermore, an influence of group size was observed for this indicator. The larger the group size, the lower was the amount of cows lying outside the cubicles $(p<0.01)$. For the indicator "percentage of dirty animals (legs)", better scores were achieved in summer season, compared with winter season $(p<0.01)$. Group size as well as herd size influenced the results significantly $(p<0.05)$. The larger the group size, the higher was the percentage of cows with dirty lower hind legs. In class C3 (41.3 \pm $5.3 \%)$, fewer animals with dirty legs compared with C1 $(57.2 \pm 6.0 \%)$ were found. With respect to the cleanliness of the body regions flank and udder no differences were observed $(p>0.05)$.

The percentages of animals with lesions or swellings and severe lameness were different in summer and winter $(p<0.01)$, but not between the herd size classes ( $p>0.05$ ). Nasal discharge was found more often in summer compared with winter $(p<0.01)$. This symptom occurred less often in $C 1(<100$ cows) than in the other 
classes $(p<0.05)$. For the indicator "percentage of cows with ocular discharge", an effect of season and interaction of season and herd size was found $(p<0.01)$. The larger the group size, the higher the incidence rate of animals with diarrhea $(p<0.01)$. In addition, a seasonal effect on the results of this indicator was determined $(p<0.01)$. The percentage of dairy cows with mastitis and vulvar discharge was influenced by the interaction of herd size and season $(p<0.01)$. The prevalence of vulvar discharge was lower in $\mathrm{C} 1$ in summer (1.0 $\pm 0.6 \%)$ compared with C4 in winter $(2.9 \pm 0.5 \%)$ and summer $(3.5 \pm 0.5 \%)$, respectively.

For the remaining health indicators "coughing", "dystocia", "downer cows", and "mortality" no effects of any of the tested effects were revealed ( $p>0.05)$. "Hampered respiration" was not observed at any of the assessments. While head butts per animal and hour were not influenced by the herd size $(p>0.05)$, the amount of displacements per animal and hour was influenced by herd size $(p<0.01)$. Compared with the other herd size classes, more displacements were counted in C1. The number of animals with an avoidance distance of 0 or 1 to $50 \mathrm{~cm}$ was influenced by the interaction of herd size and season $(p<0.05)$. In contrast, the number of animals with an avoidance distance of 50 to $100 \mathrm{~cm}$ was only affected by the season $(p<0.01)$. More cows were observed in this category during winter $(7.2 \pm 0.7 \%)$, compared to summer season $(5.3 \pm 0.7 \%)$. 
Table 3.7: Results of the Welfare Quality ${ }^{\circledR}$ assessments at the level of indicators in season 1 (summer) and season 2 (winter) for dairy farms with $<100$ cows (C1), 100299 cows (C2), 300-499 cows (C3), or $\geq 500$ cows $(C 4 ; n=20 \text {; highlighted } p \text {-values are significant }(p<0.05))^{1}$.

\begin{tabular}{|c|c|c|c|c|c|c|c|c|c|c|c|c|c|c|}
\hline & \multirow{3}{*}{ Welfare Indicator } & \multicolumn{8}{|c|}{ Herd size class } & \multirow{3}{*}{ PSE } & \multicolumn{4}{|c|}{ P-value } \\
\hline & & \multicolumn{2}{|c|}{ C1 } & \multicolumn{2}{|c|}{$\mathrm{C2}$} & \multicolumn{2}{|c|}{ C3 } & \multicolumn{2}{|c|}{ C4 } & & \multirow{2}{*}{$\begin{array}{l}\text { Herd } \\
\text { size } \\
(\mathrm{H})\end{array}$} & \multirow{2}{*}{$\begin{array}{l}\text { Sea- } \\
\text { son } \\
(\mathrm{S})\end{array}$} & \multirow{2}{*}{$\begin{array}{c}\text { Interac- } \\
\text { tion } \\
(\mathrm{H} \times \mathrm{S})\end{array}$} & \multirow{2}{*}{$\begin{array}{c}\text { Group } \\
\text { size } \\
(\mathrm{G})\end{array}$} \\
\hline & & $\mathrm{S}$ & W & S & W & S & W & $\mathrm{S}$ & W & & & & & \\
\hline \multirow{3}{*}{$\begin{array}{l}\text { D } \\
\stackrel{\equiv}{0} \\
\mathbb{\Phi} \\
\stackrel{\Phi}{亡}\end{array}$} & Percentage of very lean animals & 14.4 & 13.4 & 14.2 & 17.7 & 11.0 & 9.6 & 9.0 & 11.9 & 1.8 & 0.05 & 0.10 & $<0.01$ & 0.54 \\
\hline & Length of troughs/bowls per animal (cm) & 4.2 & 4.2 & 5.3 & 4.6 & 8.1 & 7.5 & 8.2 & 7.9 & 0.6 & $<0.01$ & 0.02 & 0.22 & $<0.01$ \\
\hline & Mean cleanliness water points $(0-2)$ & 0.4 & 0.6 & 0.6 & 0.4 & 0.5 & 0.6 & 0.4 & 0.4 & 0.1 & 0.82 & 0.80 & 0.73 & 0.85 \\
\hline \multirow{6}{*}{$\begin{array}{l}\frac{0}{5} \\
\frac{.}{5} \\
\text { 오 }\end{array}$} & Duration of the process of lying down (sec) & 5.9 & 6.0 & 5.8 & 5.9 & 5.3 & 5.6 & 5.7 & 6.0 & 0.2 & 0.03 & 0.07 & 0.83 & 0.37 \\
\hline & Percentage of collisions with cubicles & 25.2 & 14.4 & 18.4 & 21.8 & 20.0 & 9.6 & 17.5 & 19.0 & 3.7 & 0.26 & $<0.01$ & $<0.01$ & 0.15 \\
\hline & Percentage of cows lying outside cubicles & 5.6 & 3.5 & 3.8 & 2.7 & 6.5 & 4.1 & 3.6 & 2.9 & 1.4 & 0.35 & 0.04 & 0.77 & $<0.01$ \\
\hline & Percentage of dirty animals (legs) & 51.4 & 62.9 & 48.9 & 60.0 & 36.9 & 45.6 & 48.9 & 54.5 & 6.2 & 0.03 & $<0.01$ & 0.24 & 0.02 \\
\hline & Percentage of dirty animals (flanks) & 62.2 & 63.4 & 68.2 & 70.4 & 62.0 & 63.9 & 64.0 & 68.8 & 5.0 & 0.69 & 0.14 & 0.83 & 0.73 \\
\hline & Percentage of dirty animals (udder) & 45.4 & 47.3 & 50.9 & 51.0 & 34.1 & 35.7 & 39.8 & 44.2 & 5.3 & 0.09 & 0.67 & 0.89 & 0.38 \\
\hline \multirow{11}{*}{ 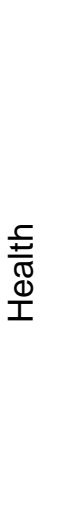 } & Percentage of cows with lesions/swellings & 31.3 & 28.4 & 40.0 & 30.1 & 32.8 & 28.4 & 34.9 & 26.5 & 3.5 & 0.50 & $<0.01$ & 0.62 & 0.80 \\
\hline & Percentage of cows with severe lameness & 39.4 & 19.8 & 33.1 & 18.1 & 21.5 & 12.1 & 22.9 & 11.3 & 3.5 & 0.10 & $<0.01$ & 0.89 & 0.16 \\
\hline & Percentage of cows with nasal discharge & 17.1 & 15.4 & 24.6 & 18.4 & 26.3 & 19.5 & 27.0 & 19.4 & 2.0 & 0.02 & $<0.01$ & 0.41 & 0.20 \\
\hline & Percentage of cows with ocular discharge & 6.8 & 0.9 & 2.7 & 0.9 & 4.1 & 2.0 & 4.9 & 1.5 & 0.9 & 0.14 & $<0.01$ & $<0.01$ & 0.91 \\
\hline & Frequency of coughing per cow/15min & 0.2 & 0.1 & 0.2 & 0.2 & 0.2 & 0.2 & 0.2 & 0.1 & 0.0 & 0.14 & 0.62 & 0.37 & 0.60 \\
\hline & Percentage of cows with diarrhea & 42.8 & 36.2 & 40.1 & 33.6 & 33.2 & 29.5 & 29.4 & 25.3 & 3.6 & 0.16 & $<0.01$ & 0.92 & $<0.01$ \\
\hline & Percentage of cows with mastitis & 20.6 & 16.8 & 19.7 & 21.4 & 21.1 & 22.4 & 22.5 & 24.7 & 2.0 & 0.31 & 0.78 & 0.01 & 0.67 \\
\hline & Percentage of cows with vulvar discharge & 1.0 & 2.2 & 1.8 & 2.3 & 1.7 & 2.5 & 3.5 & 2.9 & 0.5 & 0.05 & $<0.01$ & 0.01 & 0.80 \\
\hline & Percentage of dystocia (12 months) & 6.1 & 7.6 & 6.6 & 6.3 & 5.3 & 6.0 & 7.8 & 6.4 & 1.7 & 0.41 & 0.72 & 0.91 & 0.39 \\
\hline & Percentage of downer cows (12 months) & 4.5 & 4.4 & 3.1 & 4.3 & 3.5 & 3.6 & 2.7 & 3.0 & 0.7 & 0.72 & 0.05 & 0.91 & 1.00 \\
\hline & Percentage of mortality (12 months) & 3.6 & 3.3 & 4.5 & 4.5 & 5.2 & 5.5 & 5.8 & 6.3 & 0.8 & 0.38 & 0.73 & 0.26 & 0.33 \\
\hline \multirow{5}{*}{ 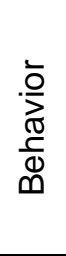 } & Head butts per animal/60 min & 0.5 & 0.4 & 0.4 & 0.4 & 0.3 & 0.3 & 0.3 & 0.3 & 0.1 & 0.69 & 0.97 & 0.57 & 0.62 \\
\hline & Displacements per animal/60 min & 0.2 & 0.2 & 0.1 & 0.1 & 0.1 & 0.1 & 0.1 & 0.1 & 0.0 & $<0.01$ & 0.02 & 0.31 & 0.07 \\
\hline & Avoidance distance test $0 \mathrm{~cm} \mathrm{( \% )}$ & 53.0 & 56.6 & 54.7 & 54.7 & 47.9 & 43.5 & 45.2 & 38.3 & 4.5 & 0.16 & 0.21 & 0.04 & 0.35 \\
\hline & Avoidance distance test 1 to $49 \mathrm{~cm} \mathrm{( \% )}$ & 40.9 & 35.6 & 40.0 & 38.6 & 47.6 & 48.6 & 47.6 & 51.2 & 3.6 & 0.07 & 0.39 & 0.02 & 0.20 \\
\hline & Avoidance distance test 50 to $100 \mathrm{~cm}(\%)$ & 5.8 & 7.4 & 5.1 & 5.6 & 3.9 & 6.9 & 6.1 & 9.0 & 1.5 & 0.55 & $<0.01$ & 0.11 & 0.86 \\
\hline
\end{tabular}




\subsection{Discussion}

\section{Limitations of the study}

The objective of the present study was to examine the relationship between herd size and animal welfare. Therefore, 80 loose housing dairy cattle farms with a maximum of 6 hours access to pasture per day were selected with different herd sizes, and animal welfare level was assessed using the WQP. This indicator system is used in several European working groups for animal welfare assessment in dairy cattle farms, but recent evaluations of the WQP revealed some methodological problems (de Graaf et al., 2017b). For example, de Vries et al. (2013) stated that single welfare indicators such as water provision or lean cows have a disproportionate effect on the overall classification, whereas other welfare-related health indicators (e.g., lameness or mastitis) were less important for the overall score. Challenges concerning the aggregation process were also described by other authors (Heath et al., 2014a,b; de Graaf et al., 2017b; Sandoe et al., 2017). Furthermore, the current strategy of sampling dairy cows for clinical examinations (e.g., lameness, lean cows, and cleanliness) might influence the results and is recommended to be modified (Van Os et al., 2018). Seasonal effects on several animal welfare indicators were observed in the present study and should also be taken into account when comparing results of different studies (Heath et al., 2014a; de Graaf et al., 2017a). Finally, insufficient inter-observer reliabilities of single indicators of the WQP such as qualitative behavior assessment (Bokkers et al., 2012), avoidance distance test (de Graaf et al., 2017a), or cleanliness and integument alterations (Heath et al., 2014b) were determined. However, under consideration of the described limitations, the WQP can be a useful instrument for on-farm animal welfare assessment in research settings (Gieseke et al., 2014; Heath et al., 2014b).

Mean herd size of the sample (383 cows) was much larger than average herd size (61 cows) in Germany (Destatis, 2017). Nevertheless, under consideration of the herd size development in recent years, it is likely that the intensification of the milk production continues with further rising herd sizes. It has to be mentioned that the thresholds of the herd size classes were selected in accordance to the farm structures in Germany. Definitions of small or large dairy cattle farms might 
be different in other countries. Therefore, results of the present study should be interpreted under consideration of the selected herd size classification. Moreover, ECM yields of the 2 lower herd size classes was about $500 \mathrm{~kg}$ lower compared with the 2 upper classes. An effect of the breed can, however, be excluded given that all farms raised Holstein Friesian cows. Other factors related to the feeding regimens or environmental conditions may have caused these differences (Bewley et al., 2008; Gauly et al., 2013), but its effect could not be further specified in this study. Even though Coignard et al. (2014) did not find an association between milk yield and overall welfare as measured with the WQP in commercial French dairy herds, further studies on this relationship are warranted and the difference in milk yield might have influenced some of the welfare parameters in the present study. Several farm types (e.g., tiestalls, straw-bedded barns, farms with pasture access) were excluded in the present study. The distribution of specific housing conditions (e.g., cubicle types, flooring types, and stall climate) was not considered during farm acquisition because no statistical data on their proportions among German dairy cattle farms were available. In general, the housing characteristics of the dairy farms in the present study (see Table 1) can be considered as typical of herds in Central Europe of the sizes assessed. Different housing conditions were considered as random farm effects in the statistical model. Additionally, known effects of the housing system (barn, floor and cubicle design) on different animal welfare indicators were integrated in the Discussion section.

\section{Overall Assessment}

The WQP overall classification widely agrees with a recent study by de Graaf et al. (2017b), who analyzed a large data set of 491 dairy cattle farms from different European countries (e.g., Macedonia, Scotland, Denmark, and Austria). The authors found $0 \%$ "excellent", $35 \%$ "enhanced", $63 \%$ "acceptable" and $2 \%$ "not classified" dairy cattle farms, which showed broad variations in terms of housing and management conditions (de Graaf et al., 2017b). Similar results were published by other working groups. Heath et al. (2014a) observed 62\% "enhanced" and $38 \%$ "acceptable" dairy cattle farms in a British study, whereas De Boyer des Roches et al. (2014) reported 37\% "enhanced", 58\% "acceptable" and 5\% "not classified" farms in France. Popescu et al. (2014) assessed loose houses and tiestalls in Romania and classified $43 \%$ of the farms as "enhanced" and $47 \%$ as 
"acceptable". Every $10^{\text {th }}$ farm was "not classified". As in the present study, none of the aforementioned studies found a farm being classified as "excellent". Comparisons to other studies regarding the effect of herd size on the overall WQP classification are not possible because the herd size was never considered as influencing factor.

\section{Principle of "Good Feeding"}

Results of the present study with a mean of $12.7 \%$ lean cows (9.0 to $17.0 \%$ ) are in accordance with other studies. For example, Popescu et al. (2014) observed on average $13.1 \%$ cows with a low body condition score (BCS) in loose houses and $10.2 \%$ in tiestalls. Zuliani et al. (2017) observed $18.3 \%$ in Italian mountain farms. Heath et al. (2014a) found on average $5.7 \%$ in a British study, whereas de Graaf et al. (2017a) observed 5.5\% in Belgium. The highest mean percentages of lean cows in the present study were found in $\mathrm{C} 2$, which increased from summer to winter, whereas the lowest percentages were found in C3 and C4 with lower seasonal differences. Because feeding management (total-mixed ration) did not differ in the farms with limited access to pasture between seasons and seasonal calving was not practiced both can be excluded as explanatory factors. Herd size effects were also stated by other studies. Adams et al. (2017) compared small ( $<100$ cows), medium (100-499 cows), and large ( $\geq 500$ cows) dairy farms. The highest within-herd prevalence of cows with a BCS $\leq 2.5$ was observed in small (9.1\%), compared with medium (3.0\%) and large (2.0\%) farms (Adams et al., 2017). An association of lower percentages of lean cows with increasing herd size was also observed in a Dutch study (de Vries et al., 2016). The advantage of larger herds might depend on the establishment of feeding groups. Different rations may be provided, which are adjusted for specific feeding requirements in particular lactation stages (Bewley and Schutz, 2008; Adams et al., 2017).

The mean length of troughs per cow in the present study was significantly higher in larger herds ( $>300$ cows). Both classes C3 and C4 provided a $7.5 \mathrm{~cm}$ trough length per cow, which is sufficient according to the WQP (threshold: $\geq 6 \mathrm{~cm}$ ). Contrastingly, classes with smaller herd sizes $\mathrm{C} 1$ and $\mathrm{C} 2$ ranged below this threshold (4 to $6 \mathrm{~cm}$; partly sufficient). In other studies, comparable scores for sufficient (43\%), partly sufficient (35\%), and not sufficient $(22 \%)$ water provision were found (de Vries et al., 2013; Heath et al., 2014b; De Boyer des Roches et al., 2014). In 
summer, most farms were scored better than in winter. This discrepancy may be explained by installation of additional troughs in the barns during summer and a noticeable number of troughs that were broken due to frost in winter. Dairy cows in a Belgian study had on average higher scores in the criterion "absence of prolonged thirst" at the end (80 points), compared to the beginning of the indoor period (60 points). Due to the high variability within the groups, no statistical effect was found (de Graaf et al., 2017a).

\section{Principle of "Good Housing"}

The average time needed to lie down ranged in between 5.3 and 6.0 seconds, depending on class and season. Comparable values were measured, for example, in France with $5.9 \mathrm{sec}$ (De Boyer des Roches et al., 2014), United Kingdom with $5.2 \mathrm{sec}$ (Heath et al., 2014a), and Denmark with $6.0 \mathrm{sec}$ (Andreasen et al., 2014) with a wide range between the farms (3.1 to $10.7 \mathrm{sec}$ ). Variances of the duration of the process of lying down might be caused by different housing conditions (Plesch et al., 2010). Farms of C3 achieved lower mean durations than farms of $\mathrm{C} 1$. These findings could be partly explained by the higher amount of 90\% deep bedded cubicles in C3 compared with 65\% in C1. Deep-bedded ones are more comfortable for the dairy cows and might reduce the time needed to lie down (Wechsler et al., 2000). Inadequate cubicle dimensions could also be detrimental for the lying down process because dairy cows might be disturbed by the cubicle partitions (Veissier et al., 2004). Furthermore, painful conditions can influence the time to lie down. For example, Popescu et al. (2013) determined strong correlations between the duration of the process of lying down and cows with lameness, lesions or mastitis $(p<0.05)$. However, these animal welfare indicators did not differ between herd size classes in the present study.

In most studies, alarm thresholds of the WQP for dirtiness of lower hind legs (50\%) and hindquarters as well as udders (20\%) were widely exceeded. For example, Heath et al. (2014a) found more than 50\% dirty udders (2 to 98\%). Comparable results for soiling of the hindquarters and lower hind legs were reported by other studies (De Boyer des Roches et al., 2014; Heath et al., 2014a; Zuliani et al., 2017). The percentage of dirty lower legs was influenced by herd size in the present study, but not the percentages of dirty hindquarters or udders. The discrepancy of $57.2 \%$ dirty lower legs in C1 and $41.2 \%$ in C3 was unexpected. 
Farms of C3 had a higher proportion of plain floors (75\%), whereas dairy farms of $\mathrm{C} 1 \mathrm{had}$ a higher proportion of slatted floors (95\%). Plain floors are usually associated with severe contaminations of the lower legs due to accumulated manure in front of the automatic scraper (Cramer et al., 2009). Probably, higher scraping frequencies in the farms of the present study have reduced the amount of manure in the alleys in comparison to other studies (DeVries et al., 2012). The observed results might also be explained by the higher percentage of deep bedded cubicles in $\mathrm{C} 3(90 \%)$ compared with $\mathrm{C} 1$ (65\%) because these have a higher absorptive capacity of the bedding material (de Vries et al., 2015; Cook et al., 2016). In every herd size class a higher prevalence of dirty lower legs was found in winter compared with summer. Walking areas are usually more humid in winter because the floors do not dry off. Therefore, dairy cows are at a higher risk of being dirty at the lower legs during winter (Ruud et al., 2010).

\section{Principle of "Good Health"}

In the present study severe integument alterations (lesions/swellings) were assessed at $31.6 \%$ of the animals, whereas herd sizes did not differ but alterations were observed more often in summer than in winter. These results comply with the mean prevalence of 39.2\% in French (Coignard et al., 2013), 37.6\% in Dutch (de Vries et al., 2013), and $29.8 \%$ in British (Heath et al., 2014a) dairy cattle farms. Risk factors for lesions and swellings are cubicles with mattresses, inadequate dimensions of feeding racks or cubicles, low body condition scores, and high milk yields (Coignard et al., 2013; Zaffino Heyerhoff et al., 2014). Summer pasturing positively affects the prevalence of integument alterations (Haskell et al., 2006; de Graaf et al., 2017a) because hairless patches, lesions, and swellings could recover on the pasture due to the softer underground (Winckler et al., 2007). In contrast, farms of the present study with a maximum of 6 hours access to pasture per day achieved constantly higher integument scores in summer $(34.8 \%)$ than in winter $(28.3 \%)$. Conceivably, cleanliness of the dairy cows might have contributed to the observed differences in the assessment of lesions and swellings. Dairy cows of the present study were less dirty in summer and could therefore be examined more easily compared to soiled animals in winter. Smaller lesions might have been invisible beneath large-scale plaques of dirt. 
The mean prevalence of severely lame cows $(22.3 \%)$ in the present study was higher compared to other studies using the WQP. A British study detected $4.9 \%$ (0.0 to $47.6 \%$ ) severely lame cows (Heath et al., 2014a), whereas de Vries et al. (2013) found $5.0 \%$ (0.0 to $65.9 \%)$ in the Netherlands. The discrepancy may be explained by the specific combination of risk factors in the study design (Dippel et al., 2009; Solano et al., 2015). Lameness is observed more often in cubicle housing systems compared with straw barns and tiestalls, which might be provoked by permanent contact with soiled alleys (Haskell et al., 2006; Coignard et al., 2013; Popescu et al., 2014). Methodological challenges of lameness detection might also have contributed to lower lameness prevalences in tiestalls ( $\mathrm{Pa}$ lacio et al., 2017). However, the most important effect for preventing lameness is access to pasture during summer season (Cook et al., 2016; de Graaf et al., 2017a). Contrastingly, higher percentages of severely lame cows were observed in summer $(29.7 \%)$ compared with the winter season (15.3\%). Under heat stress conditions, dairy cows are at a higher risk of developing claw disorders due to prolonged standing times in soiled alleys (Cook et al., 2004; Sanders et al., 2009). No association of herd size and lameness was found in the present study, which is in accordance with other authors (Barker et al., 2010; Fabian et al., 2014). In contrast, Alban et al. (1995) and de Vries et al. (2014) determined a positive relationship between herd size and lameness in dairy cattle. Increasing herd size was associated with intensive mechanization and less attention for the single cow (Alban et al., 1995). Other authors stated a negative relationship because professionalized management (trained staff, regular footbaths) is provided more frequently in larger than in smaller herds (Dippel et al., 2009; Solano et al., 2015).

Different information on prevalence of nasal discharge were found in the literature. Some authors detected only 3.7\% (Heath et al., 2014a) or 4.2\% (Zuliani et al., 2017) cows with nasal discharge. Other authors described higher proportions of cows with this symptom in France (16.4\%; Coignard et al., 2013) and Belgium (17.1\%; de Graaf et al., 2017a), which were at a comparable level to the findings of the present study (21.0\%). Increasing herd size was associated with an increased frequency of nasal discharge. Conceivably, this result is attributed to a higher infection risk in larger herds due to intensified contact to other animals and several regroupings during lactation (Torres-Cardona et al., 2014; Beggs et al., 
2015). All herd size classes had higher proportions of cows with nasal discharge in summer $(23.7 \%)$ compared with winter (18.2\%). Dairy cows have an impaired immune status under heat stress conditions (Kadzere et al., 2002), which might have increased the risk of nasal discharge due to viral or bacterial infections in summer (Canali et al., 2009). Nasal discharge as an unspecific symptom of respiratory disorders in cattle can also be caused by environmental factors such as the dust concentration in the barn (Brscic et al., 2012). However, a previous study did not determine different dust exposures in dairy cattle farms between the summer and winter season (Takei et al., 1998). Therefore, the seasonal effect on nasal discharge observed in the present study still remains unclear.

On average, $21 \%$ of the dairy cows showed signs of mastitis, determined as somatic cell counts $>400,000$ cells at least once in the last three month (Welfare Quality, 2012). The alarm threshold of the WQP was exceeded by most of the farms, which widely agrees with previous studies. Andreasen et al. (2014) described that 11 farms have surpassed the warning (8.8\%) and 29 farms the alarm threshold (17.5\%) out of 44 farms in Denmark. Coignard et al. (2013) observed on average $20.6 \%$ dairy cows with mastitis (2.0 to $46.6 \%$ ). Lower incidence rates were found with $11.1 \%$ affected cows in the Netherlands (de Vries et al., 2013) and $15.5 \%$ in the United Kingdom (Heath et al., 2014a). No significant effect of herd size on the mastitis incidence was examined in the present study. These findings were supported by other studies (Ivemeyer et al., 2011; Schewe et al., 2015). Contrastingly, some authors observed a higher risk of mastitis with increasing herd size (Lievaart et al., 2007; Archer et al., 2013), whereas other authors stated a lower risk (Oleggini et al., 2001; Ingham et al., 2011). The contradictory results found in the literature might be caused by differences within the study design. Regarding herd size, milk yield, or dominant breed only the US studies were comparable to our own study population. Oleggini et al. (2001) examined the effect of several herd size classes (20 to 49, 50 to 99,100 to 149 , 150 to 249,250 to 449 , $\geq 450$ cows) on different dairy herd performance parameters. Ingham et al. (2011) compared somatic cell counts in 3 herd size categories ( $\leq 118 ; 119$ to $713 ; \geq 714$ cows). In both publications lower somatic cell counts with increasing herd size were determined. 
In several European countries mean percentages of 0.4 to $1.0 \%$ dairy cows with vulvar discharge were found (Coignard et al., 2013; Popescu et al., 2014; Heath et al., 2014a). Results of the present study were slightly higher (2.3\%) and increased continuously with increasing herd size. Average percentages in herd size classes $\mathrm{C} 1$ to $\mathrm{C} 3$ were below the warning threshold (2.3\%), whereas the mean value of C4 was above (Welfare Quality, 2012). The larger farms of C4 ( $\geq 500$ cows) had frequently implemented a separate group for cows in the early postpartum period. Most of the dairy cows in these groups showed signs of vulvar discharge due to physiological cleaning processes of the uterus in the first weeks of lactation. The probability to include a cow with vulvar discharge in the sample was therefore higher in larger compared with smaller herds without different lactation groups. Fourichon et al. (2001) also examined the effect of herd size on the incidence of metritis and detected a higher percentage of affected cows in larger herds. In contrast, no relationship between herd size and metritis incidence was observed in Denmark (Bruun et al., 2002).

\section{Principle of "Appropriate Behavior"}

Cows in larger herds are usually confronted with regular regrouping because larger herds are often divided into smaller subgroups (Boe and Faerevik, 2003). Frequent regrouping might lead to increased agonistic interactions in the groups, due to increasing conflicts between unfamiliar cows (Boe and Faerevik, 2003; Estevez et al., 2007). The results of the present study did not support this hypothesis. A significant effect of herd size was determined, but most frequent conflicts were observed in the smallest class $\mathrm{C} 1$. The highest amount of displacements was associated with less space per cow in small walking alleys and conflicts concerning limited resources like water troughs, concentrate feeders or cow brushes. Similarly, de Vries et al. (2015) found a positive relationship between the presence of cow brushes and the number of displacements. However, in all herd size classes displacements were at a relatively low level ( 0.1 to 0.2 displacements), compared with the value of 0.4 displacements found in the Netherlands (de Vries et al., 2015), in Belgium (de Graaf et al., 2017a), and in the United Kingdom (Heath et al., 2014a). 
In larger herds different stock persons take care of a higher amount of animals and the human-animal-relationship might be less pronounced (Raussi et al., 2003). However, no negative association of herd size and avoidance distance test at the feed rack was found in the present study. Mattiello et al. (2009) and Verkerk and Hemsworth (2010) determined higher flight distances with increasing herd sizes, whereas other working groups could not verify such a relationship (Waiblinger and Menke, 1999; Waiblinger et al., 2003). The scores of the criterion "human-animal-relationship" in the present study (74 points) were comparable to 68.0 points in the Netherlands (de Vries et al., 2013) and 78.7 points in Italy (Zuliani et al., 2017). Lower scores were determined with 42.0 points in France (De Boyer des Roches et al., 2014). The observed seasonal effect with higher flight distances in winter (especially for C3 and C4) could not be explained by the collected data. Battini et al. (2011) did also find varying human-animal-relationships throughout the year, but this was attributed to management changes due to alpine summer pasturing. Contrastingly, de Graaf et al. (2017a) determined comparable human-animal-relationship scores at the beginning (35.7 points) and end (36.4 points) of the indoor period. Results of the avoidance distance tests are primarily influenced by quantity and quality of individual interactions between dairy cows and farmers (Waiblinger et al., 2003). Seasonal differences in the human-animal-relationship are warranted to be investigated in more detail in further studies.

\subsection{Conclusions}

Findings of the present study did not indicate a linear relationship between herd size and animal welfare in dairy cattle. Single animal welfare indicators (lean cows, trough length, duration of the process of lying down in a stall, dirtiness of lower legs, nasal discharge, vulvar discharge, and displacements) were associated with the number of dairy cows per farm. But the observed results were not consistent, as some welfare indicators worsened with increasing herd size, whereas others improved or showed a curvilinear relationship. Large variations of welfare levels between farms were observed in each herd size class. Therefore, herd size is not a valid indicator of animal welfare at the herd level. Housing conditions and management practices seem to have a greater effect on animal welfare than the number of dairy cows per farm. 


\subsection{Acknowledgments}

This study was funded by the German Federal Ministry of Education and Research (Berlin) within the project "Sustainable Land Management in North German Lowland" (NaLaMa-nt) and financially supported by the H. Wilhelm Schaumann Foundation (Hamburg, Germany). The authors thank the different stakeholders for their support during farm acquisition and the participating farmers for their time and effort.

\subsection{References}

Adams, A.E., J.E. Lombard, C.P. Fossler, I.N. Román-Muñiz, and C.A. Kopral. 2017. Associations between housing and management practices and the prevalence of lameness, hock lesions, and thin cows on US dairy operations. J. Dairy Sci. 100:2119-2136. https://doi.org/10.3168/jds.201611517.

Alban, L. 1995. Lameness in Danish dairy cows: frequency and possible risk factors. Prev. Vet. Med. 22:213-225. https://doi.org/10.1016/0167-5877(94) 00411-B.

Andreasen, S.N., P. Sandoe, and B. Forkman. 2014. Can animal-based welfare assessment be simplified? A comparison of the Welfare Quality ${ }^{\circledR}$ protocol for dairy cattle and the simpler and less time-consuming protocol developed by the Danish Cattle Federation. Anim. Welf. 23:81-94. https://doi. org/10.7120/09627286.23.1.081.

Archer, S.C., F. Mc Coy, W. Wapenaar, and M.J. Green. 2013. Association of season and herd size with somatic cell count for cows in Irish, English, and Welsh dairy herds. The Vet. J. 196:515-521. http://dx.doi.org/10.1016/j. tvil.2012.12.004.

Barker, Z.E., K.A. Leach, H.R. Whay, N.J. Bell, and D.C.J. Main. 2010. Assessment of lameness prevalence and associated risk factors in dairy herds in England and Wales. J. Dairy Sci. 93: 932-941. https://doi.org/10.3168/jds. 2009-2309.

Battini, M., E. Andreoli, S. Barbieri, and S. Mattiello. 2011. Long-term stability of avoidance distance tests for on-farm assessment of dairy cow relationship to humans in alpine traditional husbandry systems. Appl. Anim. Beh. Sci. 135:267-270. http://dx.doi.org/doi:10.1016/j.applanim.2011.10.013.

Beggs, D.S., A.D. Fisher, E.C. Jongman, and P.H. Hemsworth. 2015. A survey of Australian dairy farmers to investigate animal welfare risks associated 
with increasing scale of production. J. Dairy Sci. 98:5330-5338. http://dx. doi.org/10.3168/jds.2014-9239.

Bewley, J.M., and M.M. Schutz. 2008. Review: an interdisciplinary review of body condition scoring for dairy cattle. Prof. Anim. Sci. 24:507-529. https://doi. org/10.15232/S1080-7446(15)30901-3.

Boe, K.E., and G. Faerevik. 2003. Grouping and social preferences in calves, heifers and cows. Appl. Anim. Beh. Sci. 80:175-190. https://doi.org/10. 1016/S0168-1591(02)00217-4.

Bokkers, E.A.M., M. de Vries, I.C.M.A. Antonissen, and I.J.M. de Boer. 2012. Inter- and intra-observer reliability of experienced and inexperienced observers for the Qualitative Behaviour Assessment in dairy cattle. Anim. Welf. 21:307-318. https://doi.org/10.7120/09627286.21.3.307.

Brscic, M., H. Leruste, L.F.M. Heutinck, E.A.M. Bokkers, M. Wolthuis-Fillerup, N. Stockhofe, F. Gottardo, B.J. Lensink, G. Cozzi, ans C.G. Van Reenen. 2012. Prevalence of respiratory disorders in veal calves and potential risk factors. J. Dairy Sci. 95:2753-2764. http://dx.doi.org/10.3168/jds.20114699.

Bruun, J., A.K. Ersbøll, and L. Alban. 2002. Risk factors for metritis in Danish dairy cows. Prev. Vet. Med. 54:179-190. https://doi.org/10.1016/S01675877(02)00026-0.

Canali, E., H.R. Whay, and K.A. Leach. 2009. Cattle health status. In: Forkman, B. and L. Keeling (eds): Assessment of Animal Welfare Measures for Dairy Cattle, Beef Bulls and Veal Calves. Welfare Quality Reports No. 11. 7788.

Coignard, M., R. Guatteo, I. Veissier, A. de Boyer des Roches, L. Mounier, A. Lehébel, and N. Bareille. 2013. Description and factors of variation of the overall health score in French dairy cattle herds using the Welfare Quality ${ }^{\circledR}$ Assessment protocol. Prev. Vet. Med. 112:296-308. https://doi.org/10. 1016/j.prevetmed.2013.07.018.

Coignard, M., R. Guatteo, I. Veissier, A. Lehébel, C. Hoogveld, L. Mounier, and N. Bareille. 2014. Does milk yield reflect the level of welfare in dairy herds? The Vet. J. 199:184-187. http://dx.doi.org/10.1016/j.tvjl.2013.10.011.

Cook, N.B., J.P. Hess, M.R. Foy, T.B. Bennett, and R.L. Brotzman. 2016. Management characteristics, lameness, and body injuries of dairy cattle housed in high-performance dairy herds in Wisconsin. J. Dairy Sci. 99:5879-5891. https://doi.org/10.3168/jds.2016-10956.

Cook, N.B., T.B. Bennett, and K.V. Nordlund. 2004. Effect of free stall surface on daily activity patterns in dairy cows with relevance to lameness prevalence. 
J. Dairy Sci. 87:2912-2922. https://doi.org/10.3168/jds.S0022-0302(04) 73422-0.

Cramer, G., K.D. Lissemore, C.L. Guard, K.E. Leslie, and D.F. Kelton. 2009. Herd-level risk factors for seven different foot lesions in Ontario Holstein cattle housed in tie stalls or free stalls. J. Dairy Sci. 92:1404-1411. https:// doi.org/ 10.3168/jds.2008-1134.

Dairy Australia, 2015. Cows and farms. www.dairyaustralia.com.au/Markets-andstatistics/Farm-facts/Cows-and-Farms.aspx (Accessed 10. February 2017).

Dairy New Zealand. 2014. New Zealand Dairy Statistics 2013-2014. www.dairynz.co.nz/media/1327583/nz-dairy-statistics-2013-2014-web.pdf (Accessed 10. February 2017).

De Boyer des Roches, A., I. Veissier, M. Coignard, N. Bareille, R. Guatteo, J. Capdeville, E. Gilot-Fromont, and L. Monier. 2014. The major welfare problems of dairy cows in French commercial farms: an epidemiological approach. Anim. Welf. 23:467-478. https://doi.org/10.7120/09627286.23. 4.467.

De Graaf, S., B. Ampe, and F.A.M. Tuyttens. 2017a. Assessing dairy cow welfare at the beginning and end of the indoor period using the Welfare Quality ${ }^{\circledR}$ protocol. Anim. Welf. 26: 213-221. https://doi.org/10.7120/0962728626. 2.213.

De Graaf, S., B. Ampe, C. Winckler, M. Radeski, L. Mounier, M.K. Kirchner, M.J. Haskell, F.J.C.M. van Eerdenburg, A. de Boyer des Roches, S.N. Andreasen, J. Bijttebier, L. Lauwers, W. Verbeke, and F.A.M. Tuyttens. 2017b. Trained-user opinion about Welfare Quality measures and integrated scoring of dairy cattle welfare. J. Dairy Sci. 100:6376-6388. https://doi.org/ 10.3168/jds.2016-12255.

De Vries, M., E.A.M. Bokkers, C.G. van Reenen, B. Engel, G. van Schaik, T. Dijkstra, and I.J.M. de Boer. 2015. Housing and management factors associated with indicators of dairy cattle welfare. Prev. Vet. Med. 118:80-92. https://doi.org/10.1016/j.prevetmed. 2014.11.016.

De Vries, M., E.A.M. Bokkers, G. van Schaik, B. Engel, T. Dijkstra, and J.M. de Boer. 2014. Exploring the value of routinely collected herd data for estimating dairy cattle welfare. J. Dairy Sci. 97:715-730. http://dx.doi.org/ 10.3168/jds.2013-6585.

De Vries, M., E.A.M. Bokkers, G. van Schaik, B. Engel, T. Dijkstra, and I.J.M. de Boer. 2016. Improving the time efficiency of identifying dairy herds with poorer welfare in a population. J. Dairy Sci. 99:8282-8296. http://dx. doi.org/ 10.3168/jds.2015-9979. 
De Vries, M., E.A.M. Bokkers, G. van Schaik, R. Botreau, B. Engel, T. Dijkstra, and I.J.M. de Boer. 2013. Evaluating results of the Welfare Quality multicriteria evaluation model for classification of dairy cattle welfare at the herd level. J. Dairy Sci. 96:6264-6273. http://dx.doi.org/10.3168/jds.2012-6129.

Destatis. 2017. Land- und Forstwirtschaft, Fischerei Rinder- und Schweinebestand Statistisches Bundesamt. Fachserie 3 Reihe 4.1. www.destatis.de/DE/Publikationen/Thematisch/LandForstwirtschaft/ViehbestandTierischeErzeugung/Viehhaltung2030213169004.pdf?_blob=publicationFile (Accessed 07. June 2017).

DeVries, T.J., M.G. Aarnoudse, H.W. Barkema, K.E. Leslie, and M.A.G. von Keyserlingk. 2012. Associations of dairy cow behavior, barn hygiene, cow hygiene, and risk of elevated somatic cell count. J. Dairy Sci. 95:5730-5739. http://dx.doi.org/10.3168/ jds.2012-5375.

Dippel, S., M. Dolezal, C. Brenninkmeyer, J. Brinkmann, S. March, U. Knierim, and C. Winckler. 2009. Risk factors for lameness in cubicle housed Austrian Simmental dairy cows. Prev. Vet. Med. 90:102-112. http://dx.doi.org/ 10.1016/j.prevetmed.2009.03.014.

Estevez, I., I.L. Andersen, and E. Naevdal. 2007. Group size, density and social dynamics in farm animals. Appl. Anim. Beh. Sci. 103:185-204. https:// doi.org/10.1016/i.applanim.2006.05.025.

European Commission. 2016. Attitudes of Europeans towards animal welfare. Special Eurobarometer 442. http://ec.europa.eu/COMMFrontOffice/publicopinion/index.cfm/Survey/getSurveyDetail/instruments/SPECIAL/surveyKy/2096 (Accessed 05. May 2017).

Eurostat. 2015. Milk and milk products - 30 years of quotas. Historical data on the milk sector (1983-2013). http://ec.europa.eu/eurostat/statistics-explained/index.php/Milk_and_milk_products_-_30_years_of_quotas (Accessed 10. May 1017).

Fabian, J., R.A. Laven, and H.R. Whay. 2014. The prevalence of lameness on New Zealand dairy farms: A comparism of farmer estimate and locomotion scoring. The Vet. J. 201:31-38. http://dx.doi.org/10.1016/j.tvjl.2014.05. 011.

Fourichon, C., F. Beaudeau, N. Bareille, and H. Seegers. 2001. Incidence of health disorders in dairy farming systems in western France. Livest. Prod. Sci. 68:157-170. https://doi.org/ 10.1016/S0301-6226(00)00249-9.

Gauly, M., H. Bollwein, G. Breves, K. Brügeman, S. Dänicke, G. Das, J. Demeler, H. Hansen, J. Isselstein, S. König, M. Lohölter, M. Martinsohn, U. Meyer, M. Potthoff, C. Sanker, B. Schröder, N. Wrage, B. Meibaum, G. von Sam- 
son-Himmelstjerna, H. Stinshoff, and C. Wrenzycki. 2013. Future consequences and challenges for dairy cow production systems arising from climate change in Central Europe - a review. Animal. 7:843-859. https://doi. org/10.1017/S1751731112002352.

Gieseke, D., C. Lambertz, I. Traulsen, J. Krieter, and M. Gauly. 2014. Beurteilung von Tiergerechtheit in der Milchviehhaltung - Evaluierung des Welfare Quality ${ }^{\circledR}$ Protokolls. Züchtungskunde. 86:58-70. ISSN 0044-5401.

Haskell, M.J., L.J. Rennie, V.A. Bowell, M.J. Bell, and A.B. Lawrence. 2006. Housing system, milk production, and zero-grazing effects on lameness and leg injury in dairy cows. J. Dairy Sci. 89:4259-4266. https://doi.org/10. 3168/jds.S0022-0302(06)72472-9.

Heath, C.A.E., W.J. Browne, S. Mullan, and D.C.J. Main. 2014b. Navigating the iceberg: reducing the number of parameters within the Welfare Quality ${ }^{\circledR}$ Assessment protocol for dairy cows. Animal. 8:1978-1986. https://doi.org/ 10.1017/S1751731114002018.

Heath, C.A.E., Y. Lin, S. Mullan, W.J. Browne, and D.C.J. Main. 2014a. Implementing Welfare Quality ${ }^{\circledR}$ in UK assurance schemes: evaluating the challenges. Anim. Welf. 23: 95-107. https://doi.org/10.7120/09627286.23.1.0 $\underline{95}$.

Ingham, S.C., Y. Hu, and C. Ané. 2011. Comparison of bulk-tank standard plate count and somatic cell count for Wisconsin dairy farms in three size categories. J. Dairy Sci. 94:4237-4241. https://doi.org/10.3168/jds.2011-4310.

Ivemeyer, S., U. Knierim, and S. Waiblinger. 2011. Effect of human-animal relationship and management on udder health in Swiss dairy herds. J. Dairy Sci. 94: 5890-5902. https://doi.org/10.3168/jds.2010-4048.

Kadzere, C.T., M.R. Murphy, N. Silanikove, and E. Maltz. 2002. Heat stress in lactating dairy cows: a review. Livest. Prod. Sci. 77:59-91. https://doi.org/ 10.1016/S0301-6226(01) 00330-X.

Krystallis, A., M. Dutra de Barcellos, J.O. Kügler, W. Verbeke, and K.G. Grunert. 2009. Attitudes of European citizens towards pig production systems. Livest. Sci. 126:46-56. https://doi.org/10.1016/j.livsci.2009.05.016.

Lievaart, J.J., H.W. Barkema, W.D.J. Kremer, J. van den Broek, J.H.M. Verheijden, and J.A.P. Heesterbeek. 2007. Effect of herd characteristics, management practices, and season on different categories of the herd somatic cell count. J. Dairy Sci. 90:4137-4144. https://doi.org/10.3168/jds. 2006-847.

MacDonald, J. M., E. J. O'Donoghue, W. D. McBride, R. F. Nehring, C. L. Sandretto, and R. Mosheim. 2007. Profits, costs, and the changing structure 
of dairy farming. www.ers.usda.gov/media/188030/err47_1_.pdf (Accessed 10. April 2015).

Mattiello, S., C. Klotz, D. Baroli, M. Minero, V. Ferrante, and E. Canali. 2009. Welfare problems in alpine dairy cattle farms in Alto Adige (Eastern Italian Alps). Ital. J. Anim. Sci. 8: 628-630. https://doi.org/10.4081/ijas.2009.s2. 628.

Oleggini, G.H., L.O. Ely, and J.W. Smith. 2001. Effect of region and herd size on dairy herd performance parameters. J. Dairy Sci. 84:1044-1050. https:// doi.org/10.3168/jds.S0022 -0302(01)74564-X.

Palacio, S., L. Peignier, C. Pachoud, C. Nash, S. Adam, R. Bergeron, D. Pellerin, A.M. de Passillé, J. Rushen, D. Haley, T.J. DeVries, and E. Vasseur. 2017. Technical Note: Assessing lameness in tie-stalls using live stall lameness scoring. J. Dairy Sci. 100:6577-6582. https://doi.org/ 10.3168/jds.201612 171.

Plesch, G., N. Broerkens, S. Laister, C. Winckler, and U. Knierim. 2010. Reliability and feasibility of selected measures concerning resting behaviour for the on-farm welfare assessment in dairy cows. Appl. Anim. Beh. Sci. 126:1926. https://doi.org/10.1016/j.applanim.2010.05.003.

Popescu, S., C. Borda, E.A. Diugan, M. Niculae, R. Stefan, and C.D. Sandru. 2014. The effect of the housing system on the welfare quality of dairy cows. Ital. J. Anim. Sci. 13:2940. https://doi.org/10.4081/ijas.2014.2940.

Popescu, S., C. Borda, E.A. Diugan, M. Spinu, I.S. Groza, and C.D. Sandru. 2013. Dairy cows welfare quality in tie-stall housing system with or without access to exercise. Acta Vet. Scand. 55: 43-54. https://doi.org/10.1186/ 1751-0147-55-43.

Prickett, R.W., F.B. Norwood, and J.L. Lusk. 2010. Consumer preferences for farm animal welfare: results from a telephone survey of US households. Anim. Welf. 19: 335-347. ISSN 0962-7286.

Raussi, S. 2003. Human-cattle interactions in group housing. Appl. Anim. Beh. Sci. 80:245-262. https://doi.org/10.1016/S0168-1591(02)00213-7.

Robbins, J.A., M.A.G. von Keyserlingk, D. Fraser, and D.M. Weary. 2016. Invited review: Farm size and animal welfare. J. Anim. Sci. 94:5439-5455. https:// doi.org/10.2527/jas.2016-0805.

Ruud, L.E., K.E. Boe, and O. Osteras. 2010. Risk factors for dirty dairy cows in Norwegian freestall systems. J. Dairy Sci. 93:5216-5224. https://doi.org/ 10.3168/jds.2010-3321.

Sanders, A.H., J.K. Shearer, and A. De Vries. 2009. Seasonal incidence of lameness and risk factors associated with thin soles, white line disease, ulcers, 
and sole punctures in dairy cattle. J. Dairy Sci. 92:3165-3174. https:// doi.org/ 10.3168/jds.2008-1799.

Sandoe, P., B. Forkman, F. Hakansson, S.N. Andreasen, R. Nohr, M. Denwood, and T.B. Lund. 2017. Should the contribution of one additional lame cow depend on how many other cows on the farm are lame? Animals. 7:96108. https://doi.org/10.3390/ani7120096.

Schewe, R.L., J. Kayitsinga, G.A. Contreras, C. Odom, W.A. Coats, P. Durst, E.P. Hovingh, R.O. Martinez, R. Mobley, S. Moore, and R.J. Erskine. 2015. Herd management and social variables associated with bulk tank somatic cell count in dairy herds in the eastern United States. J. Dairy Sci. 98:76507665. https://doi.org/10.3168/jds.2014-8840.

Simensen, E., O. Osteras, K.E. Boe, C. Kielland, L.E. Ruud, and G. Naess. 2010. Housing system and herd size interactions in Norwegian dairy herds; associations with performance and disease incidence. Acta Vet. Scand. 52:14. https://doi.org/10.1186/1751-0147-52-14.

Solano, L., H. W. Barkema, E. A. Pajor, S. Mason, S. J. LeBlanc, J. C. Zaffino Heyerhoff, C. G. R. Nash, D. B. Haley, E. Vasseur, D. Pellerin, J. Rushen, A. M. de Passillé, and K. Orsel. 2015. Prevalence of lameness and associated risk factors in Canadian Holstein-Friesian cows housed in freestall barns. J. Dairy Sci. 98:6978-6991. https://doi.org/10.3168/jds.2015-9652.

Sorensen, J.T, and D. Fraser. 2010. On-farm welfare assessment for regulatory purposes: issues and possible solutions. Livest. Sci. 131:1-7. https://doi.org/10.1016/j.livsci.2010.02.025.

Spooner, J.M., C.A. Schuppli, and D. Fraser. 2014. Attitudes of Canadian citizens toward animal welfare: A qualitative study. Livest. Sci. 163:150-158. https://doi.org/10.1016/j.livsci.2014.02.011.

Takai, H., S. Pedersen, J.O. Johnsen, J.H.M. Metz, P.W.G. Groot Koerkamp, G.H. Uenk, V.R. Phillips, M.R. Holden, R.W. Sneath, J.L. Short, R.P. White, J. Hartung, J. Seedorf, M. Schröder, K.H. Linkert, and C.M. Wathes. 1998. Concentrations and Emissions of Airborne Dust in Livestock Buildings in Northern Europe. J. Agric. Engng. Res. 70:59-77. https://doi.org/ 10.1006/jaer.1997.0280.

Torres-Cardona, M.G., M.E. Ortega-Cerrilla, J.I. Alejos-de la Fuente, J. HerreraHaro, and J.G. Peralta Ortiz. 2014. Effect of regrouping Holstein cows on milk production and physical activity. J. Anim. Plant Sci. 22:3433-3438. ISSN 2071-7024.

Van Os, J.M.C., C. Winckler, J. Trieb, S.V. Matarazzo, T.W. Lehenbauer, J.D. Champagne, and C.B. Tucker. 2018. Reliability of sampling strategies for 
measuring dairy cattle welfare on commercial farms. J. Dairy Sci. 101:1495-1504. https://doi.org/ 10.3168/jds.2017-13611.

Vanhonacker, F., and W. Verbeke. 2014. Public and consumer policies for higher welfare food products: challenges and opportunities. J. Agric. Environ. Ethics. 27:153-171. https:// doi.org/10.1007/s10806-013-9479-2.

Vanhonacker, F., W. Verbeke, E. Van Poucke, and F.A.M. Tuyttens. 2008. Do citizens and farmers interpret the concept of farm animal welfare differently? Livest. Sci. 116:126-136. https://doi.org/10.1016/j.livsci.2007.09. $\underline{017}$.

Veissier, I., J. Capdeville, and E. Delval. 2004. Cubicle housing systems for cattle: Comfort of dairy cows depends on cubicle adjustment. J. Anim. Sci. 82:3321-3337. https://doi.org/ 10.2527/2004.82113321x.

Verkerk, G.A., and P.H. Hemsworth. 2010. Managing cow welfare in large dairy herds. Pages 436-443 in Proc. of the $4^{\text {th }}$ Australasian Dairy Science Symposium. Lincoln University, Christchurch, New Zealand.

Waiblinger, S., and C. Menke. 1999. Influence of herd size on human-cow relationships. Anthrozoos. 12:240-247. https://doi.org/10.2752/089279399787 $\underline{000156 .}$

Waiblinger, S., C. Menke, and D.W. Fölsch. 2003. Influences on the avoidance and approach behavior of dairy cows towards humans on 35 farms. Appl. Anim. Beh. Sci. 84:23-39. https://doi.org/10.1016/S0168-1591(03)00148$\underline{5 .}$

Wechsler, B., J. Schaub, K. Friedli, and R. Hauser. 2000. Behaviour and leg injuries in dairy cows kept in cubicle systems with straw bedding or soft lying mats. Appl. Anim. Beh. Sci. 69:189-197. https://doi.org/10.1016/S016815 91(00)00134-9.

Welfare Quality ${ }^{\circledR}$. 2012. Welfare Quality ${ }^{\circledR}$ Assessment protocol for cattle. Welfare Quality ${ }^{\circledR}$ Consortium, Lelystad, Netherlands. www.welfarequalitynetwork.net/network/45848/ 7/0/40 (Accessed 21. August 2017).

Whitaker, D.A., A.I. Macrae, and E. Burrough. 2004. Disposal and disease rates in British dairy herds between April 1998 and March 2002. Vet. Rec. 155:43-47. https://dx.doi.org/10.1136/vr.155.2.43.

Winckler, C., J. Brinkmann, and J. Glatz. 2007. Long-term consistency of selected animal-related welfare parameters in dairy farms. Anim. Welf. 16:197-199. ISSN 0962-7286. 
Zaffino Heyerhoff., J.C., S.J. LeBlanc, T.J. DeVries, C.G.R. Nash, J. Gibbons, K. Orsel, H.W. Barkema, L. Solano, J. Rushen, A.M. de Passillé, and D.B. Haley. 2014. Prevalence of and factors associated with hock, knee, and neck injuries on dairy cows in freestall housing in Canada. J. Dairy Sci. 97:173-184. https://dx.doi.org/10.3168/jds.2012-6367.

Zuliani, A., A. Romanzin, M. Corazzin, S. Salvador, J.C. Abrahantes, and S. Bovolenta. 2017. Welfare assessment in traditional mountain dairy farms: above and beyond resource-based measures. Anim. Welf. 26: 203-211. https://doi.org/10.7120/09627286.26.2.203. 


\section{KAPITEL 4}

Effect of Stocking Density on Animal Welfare in Dairy Cattle

Prepared for submission

Animal 


\section{Kapitel 4 Effect of Stocking Density on Animal Welfare}

\section{Effect of Stocking Density on Animal Welfare Parameters in Dairy Cattle recorded with the Welfare Quality ${ }^{\circledR}$ Protocol}

D. Gieseke ${ }^{1}$, C. Lambertz ${ }^{2}$ and M. Gauly ${ }^{2}$

${ }^{1}$ Department of Animal Sciences, Georg-August-University of Goettingen, Germany

${ }^{2}$ Faculty of Science and Technology, Free University of Bolzano, Bolzano, Italy

\subsection{Abstract}

The objective of this study was to examine the effect of stocking density on animal welfare in dairy cattle farming. Therefore, 75 conventional dairy cattle farms were assessed using multiple animal-based measures of the Welfare Quality ${ }^{\circledR}$ protocol for dairy cattle and categorized by different cow-to-stall ratios, cow-to-feeding place ratios and walking space availabilities per cow. Stocking density groups were classified by low (73-95\%), medium (96-103\%) or high (105-133\%) cow-tostall ratios, low (67-104\%), medium (105-121\%) or high (122-163\%) cow-to-feeding place ratios and high (4.5-7.0 $\left.\mathrm{m}^{2}\right)$, medium (3.7-4.4 $\left.\mathrm{m}^{2}\right)$ or low $\left(2.5-3.6 \mathrm{~m}^{2}\right)$ walking space availability. Data were recorded from April 2014 to September 2016 by one experienced assessor in northern Germany. Only farms with loose housing systems and zero-pasturing were included in the study. Data were statistically analyzed using a generalized linear mixed model. The number of severely lame cows were higher in farms with high (37.7\%), compared to farms with low $(22.3 \%)$ to medium (23.0\%) cow-to-stall ratios. Percentages of cows with nasal discharge differed between farms with high (19.1\%) and farms with low (25.7\%) cow-to-feeding place ratios. Similarly, most head butts per cow and hour were recorded in farms with low (0.6), compared to farms with medium and high cow-to-feeding place ratios (0.3). Scores of the criterion "positive emotions" were higher in farms with medium (85.1 points) and high (83.9 points), compared to farms with low (74.1 points) cow-to-feeding place ratios. Highest percentages of severely lame cows were observed in farms with medium (31.2\%) to high 
(33.1\%), whereas lowest percentages were found in farms with low (18.8\%) walking space availabilities. Contrastingly, the highest percentages of cows with mastitis $(23.7 \%)$ were determined in farms with low, compared to medium walking space availabilities (17.8\%). No other indicators of the Welfare Quality ${ }^{\circledR}$ protocol were affected by the examined stocking density parameters. In conclusion, findings of the present study did not indicate a consistent relationship between stocking density and animal welfare in dairy cattle. Some animal welfare indicators were better in farms with higher stocking densities, while others were better in farms with lower stocking densities. Therefore, stocking density cannot be considered as a feasible indicator of the on-farm animal welfare level. Parameters of stocking density (cow-to-stall ratio, cow-to-feeding place ratio, and walking space availability) affect animal welfare of dairy cows in different ways and should therefore be considered simultaneously for optimizing housing and management in dairy cattle farms.

Keywords: animal welfare, dairy cow, stocking density, welfare quality ${ }^{\circledR}$ protocol for dairy cattle

\subsection{Introduction}

Stocking density in dairy cattle farms with loose housing systems is usually defined as the number of dairy cows in relation to provided resources like cubicles or pen space (Krawczel et al., 2012b). The concentration of dairy cattle within in a barn can be quantitatively measured by calculating cow-to-stall ratios, cow-tofeeding place ratios or surface area per cow (De Vries et al., 2016). Stocking densities in dairy cattle farms often exceed the recommended balanced ratio of $1: 1(100 \%)$ between the number of dairy cows in the barns and the amount of cubicles or feeding places (USDA, 2010). Herds were classified as overstocked $(>100 \%)$, if the number of dairy cows is higher than the amount of provided resources. In contrast, herds were classified as understocked $(<100 \%)$, if the number of dairy cows is lower than the amount of provided resources (Wang et al., 2016). Cow-to-stall ratios between $71 \%$ and $197 \%$ were observed in North America and more than $60 \%$ of the farms overstocked their herds permanently (von Keyserlingk et al., 2012). Overstocking primarily occurs due to economic rea- 
sons, because in this manner dairy farmers are able to increase herd sizes without investing in new facilities (Proudfoot and Habing, 2015; De Vries et al., 2016). Housing under overstocked conditions might lead to physiological stress and therefore impair animal welfare of dairy cows (Chebel et al., 2016). Effects of different cow-to-stall ratios, cow-to-feeding place ratios or space availabilities on primarily behavioral parameters such as lying, feeding or social behavior were examined in numerous scientific studies. For example, Hill et al. (2009) reported that total lying time and feeding time after milking decreased with increasing cowto-stall ratios $(p<0.05)$. In contrast, Wang et al. (2016) did not find an influence of varying cow-to-stall ratios $(82,100$, and $129 \%)$ on lying time, lying bouts, feeding time or dry matter intake. Huzzey et al. (2006) examined the influence of different feed bunk spaces $(0.81,0.61,0.41$, and $0.21 \mathrm{~m} / \mathrm{cow})$ on several behavioral patterns and investigated an association of less feed bunk space per cow with shortened feeding times, more inactive standing in the walking alleys and a higher amount of agonistic behaviors. Furthermore, Krawczel et al. (2012b) observed linear increases of displacements with decreasing cow-to-feeding place ratios, but feeding time and ruminating time were not affected. Fregonesi and Leaver (2002) did not find an effect of low (5.5 m²/cow) compared to high $\left(6.7 \mathrm{~m}^{2} / \mathrm{cow}\right)$ walking space availability on milk production, body condition score or dry matter intake, whereas agonistic interactions differed between both treatments $(p<0.05)$. Contrastingly, displacements at the feed bunk did not increase in a smaller (60 $\left.\mathrm{m}^{2}\right)$, compared to a larger pen $\left(120 \mathrm{~m}^{2}\right)$ - each housed with 6 or 12 dairy cows within a study of Telezhenko et al. (2012). All cited studies used experimental designs to investigate short-term effects of different stocking densities on several animal welfare parameters (Chebel et al., 2016; De Vries et al., 2016). However, examinations of long-term effects on the general welfare level of dairy cows require larger studies on commercial dairy farms providing different stocking densities (Krawczel et al., 2012b; Proudfoot and Habing, 2015). Therefore, the objective of the present study was to examine the relationship between different parameters of stocking density and animal welfare and to analyze whether stocking density parameters could be used as an indicator of the on-farm animal welfare level. Due to the multidimensional character of animal welfare (EFSA, 2010), no consistent associations between the two factors were expected. Nevertheless, maximum stocking densities (e.g., cow-to feeding place ratios) are discussed as 
participation requirement for specific animal welfare labels (German Animal Welfare Society, 2018). A total of 75 conventional dairy cattle farms with different cow-to-stall ratios (CSR), cow-to-feeding place ratios (CFR) and walking space availabilities (WSA) were assessed using multiple animal-based measures of the Welfare Quality ${ }^{\circledR}$ protocol (WQP) for dairy cattle (Welfare Quality, 2012).

\subsection{Material and Methods}

\section{Study Design}

Data collection was conducted from April 2014 to September 2016 by one single assessor on 75 conventional dairy farms located in northern Germany. Each farm was visited 2 times at an interval of 6 months (summer period and winter period) to avoid seasonal effects on the animal welfare assessment. The animal welfare level was assessed once at each dairy farm using the WQP. This is a standardized indicator system for on-farm animal welfare assessment. It focuses mainly on animal-based measures, which directly reflect the actual welfare state of the animals. More than 30 animal welfare indicators from the fields of feeding, housing, health and behavior were measured and aggregated to 12 welfare criteria, 4 welfare principles and finally one overall score (Welfare Quality, 2012). The assessor was trained intensively by a member of the Welfare Quality ${ }^{\circledR}$ Network to ensure the correct application of the WQP. The official four-day training course consisted of theoretical exercises with photos and videos as well as practical applications of the WQP on different dairy cattle farms.

\section{Farm Selection}

Farm acquisition was organized with the support of different agricultural stakeholders. For participation in the study some specific requirements had to be fulfilled to guarantee the comparability of the housing environment. All lactating dairy cows in the sample had to be kept in free stall barns. The dominant breed was Holstein Friesian, so that genetic effects could be excluded. Only farms with a maximum access to pasture of six hours per day were used the study, because an inclusion of farms with higher levels would lead to a substantial confounding effect due to high weightings within the WQP. There were no other limitations concerning housing conditions, milking techniques or feeding systems (Table 4.8.) The 75 dairy cattle farms were examined regarding three relevant stocking density parameters (cow-to-stall ratio, cow-to-feeding place ratio, and walking 
space availability), respectively. Due to the lack of clear thresholds for low, medium or high stocking densities, dairy cattle farms were separated in groups of 25 farms by calculating the tertiles of the selected stocking density parameters. Groups were classified by low (73-95\%), medium (96-103\%) or high (105-133\%) cow-to-stall ratios, low (67-104\%), medium (105-121\%) or high (122-163\%) cowto-feeding place ratios and high (4.5-7.0 $\left.\mathrm{m}^{2}\right)$, medium (3.7-4.4 $\left.\mathrm{m}^{2}\right)$ or low (2.5-3.6 $\mathrm{m}^{2}$ ) walking space availability. These groups were compared regarding the results of the WQP, in order to assess the potential effects of low, medium or high provision of cubicles, feeding places or space per cow on several animal welfare indicators. Mean herd sizes of the dairy cattle farms and maximum group sizes were documented, defined as the maximum number of dairy cows within a lactation group. These were considered, because associations between single animal welfare indicators and herd size or group size, rather than stocking density, were assumed.

\section{Data Collection}

Animal welfare assessments were conducted following the instructions of the WQP for dairy cattle (Welfare Quality, 2012). Minor modifications were made for practical or statistical reasons (e.g., non-lactating cows and cows in hospital pens were excluded). Modified animal welfare indicators and assessment methods executed on 85 dairy farms are described in Supplementary Table S1. Ten farms were excluded due to missing information on stocking densities. Datasets of the 75 dairy cattle farms were complete for all measures of the WQP ( $2^{\text {nd }}$ farm visit). In addition to the indicators of the WQP, farm characteristics like barn, cubicle and floor design, feeding system or stocking densities were recorded at the second farm visit. Cow-to-stall ratio was calculated by counting animals and stalls in each group of lactating dairy cows. Cow-to-feeding place ratio was calculated by assessing the number of feed racks and the number of dairy cows per group. In farms with neck tubes, length of the feed alley was measured and divided by 0.6 $\mathrm{m}$ to estimate the cow-to-feeding place ratio as proposed by von Keyserlingk et al. (2012). Surfaces of walking alleys, feeding alleys, crossovers and, if appropriate, loafing yards were summed up and divided by the number of dairy cows per group to calculate the provided walking space availabilities $\left(\mathrm{m}^{2}\right)$. 
The stocking density parameters were weighted by the number of dairy cows in each lactation group, because housing conditions and group sizes partly differed within the farms. Average number of dairy cows in the farms (herd size), time of the year in which animal welfare assessment was conducted (winter season = November to April; summer season = May to October) and maximum number of dairy cows within a pen (group size), were documented and considered as covariates in statistical analysis.

\section{Statistical Analysis}

Data were checked prior to analysis for normal distribution using the test of Shapiro-Wilk $(p<0.05)$. If normal distribution was not given, data were log-, sqrtor arcsin-transformed. For parameters without normal distribution after transformation, p-values were calculated assuming a Poisson distribution. All statistical analyses were computed with SAS, version 9.4 (Statistical Analysis Systems, Cary, NC, USA) using the GLIMMIX procedure. The following linear mixed effects model was used to analyze principles, criteria and indicators:

$$
Y_{i j k \mid m n o}=\mu+a_{i}+b_{j}+c_{k}+d_{l}+e_{m}+f_{n}+g_{0}+\varepsilon_{i j k \mid m n o}
$$

with $Y_{\mathrm{ijk} \mid m n o}=$ observed value of criteria or indicators, $\mu=$ overall average of sample, $a_{i}=$ fixed effect of cow-to-stall ratio $i$ (low, medium, high), $b_{j}=$ fixed effect of cow-to-feeding place ratio $\mathrm{j}$ (low, medium, high), $\mathrm{ck}=$ fixed effect of walking space availability $\mathrm{k}$ (high, medium, low), $\mathrm{d}_{\mathrm{l}}=$ fixed effect of season I (summer, winter), $e_{m}=$ covariate of herd size $m$ (continuous), $f_{n}=$ covariate of group size $n$ (continuous), $g_{\circ}=$ random effect of the farm $\circ$ and $\varepsilon_{i j k l m n o}=$ residual error. The lowest value of the Akaike information criterion (AIC) was used to select optimal covariance structure of the model. Farm was defined as statistical unit and results were considered as statistically significant at $p<0.05$. Differences between stocking density classes were assessed by applying the Tukey-Kramer test. Scores are presented as least square means (LSM) and pooled standard errors (PSE). 
Table 4.8: Characteristics of 75 conventional dairy cattle farms classified by low (73-95\%), medium (96-103\%) or high (105-133\%) cow-to-stall ratios, low (67-104\%), medium (105-121\%) or high (122-163\%) cow-to-feeding place ratios, and high (4.5-7.0 $\left.\mathrm{m}^{2}\right)$, medium (3.7-4.4 $\left.\mathrm{m}^{2}\right)$ or low $\left(2.5-3.6 \mathrm{~m}^{2}\right)$ walking space availability [Mean \pm standard deviation; ECM = energy corrected milk; Season = time of the year WQP was conducted (summer $=$ May to October, winter $=$ November to April)].

\begin{tabular}{|c|c|c|c|c|c|c|c|c|c|c|}
\hline \multirow{3}{*}{ Farm data } & \multirow{3}{*}{ Parameter } & \multicolumn{9}{|c|}{ Stocking Density Categories } \\
\hline & & \multicolumn{3}{|c|}{ Cow-to-Stall Ratio (CSR) } & \multicolumn{3}{|c|}{ Cow-to-Feeding Place Ratio (CFR) } & \multicolumn{3}{|c|}{ Walking Space Availability (WSA) } \\
\hline & & $\begin{array}{c}\text { S1 } \\
\text { (low) }\end{array}$ & $\begin{array}{c}\mathrm{S} 2 \\
\text { (medium) }\end{array}$ & $\begin{array}{c}\text { S3 } \\
\text { (high) }\end{array}$ & $\begin{array}{l}\mathrm{F} 1 \\
\text { (low) }\end{array}$ & $\begin{array}{c}\mathrm{F} 2 \\
\text { (medium) }\end{array}$ & $\begin{array}{c}\text { F3 } \\
\text { (high) }\end{array}$ & $\begin{array}{c}\text { W1 } \\
\text { (high) }\end{array}$ & $\begin{array}{c}\text { W2 } \\
\text { (medium) }\end{array}$ & $\begin{array}{l}\text { W3 } \\
\text { (low) }\end{array}$ \\
\hline \multirow[t]{2}{*}{$\operatorname{CSR}(\%)$} & Mean \pm SD & $88 \pm 6$ & $99 \pm 3$ & $113 \pm 7$ & $96 \pm 11$ & $96 \pm 8$ & $108 \pm 11$ & $94 \pm 10$ & $100 \pm 10$ & $107 \pm 12$ \\
\hline & Range & $73-95$ & $96-103$ & $105-133$ & $73-118$ & $81-116$ & $88-133$ & $73-116$ & $83-117$ & $84-133$ \\
\hline \multirow[t]{2}{*}{ CFR (\%) } & Mean \pm SD & $105 \pm 19$ & $112 \pm 18$ & $123 \pm 19$ & $93 \pm 9$ & $110 \pm 4$ & $136 \pm 12$ & $105 \pm 18$ & $115 \pm 18$ & $120 \pm 21$ \\
\hline & Range & $67-158$ & $78-157$ & $96-163$ & $67-104$ & $105-121$ & $122-163$ & $67-140$ & $85-158$ & $88-163$ \\
\hline \multirow[t]{2}{*}{ WSA $\left(m^{2}\right)$} & Mean \pm SD & $4.5 \pm 0.9$ & $4.3 \pm 0.9$ & $3.6 \pm 0.6$ & $4.5 \pm 1.0$ & $4.2 \pm 0.8$ & $3.8 \pm 0.8$ & $5.1 \pm 0.6$ & $4.1 \pm 0.2$ & $3.3 \pm 0.3$ \\
\hline & Range & $3.2-7.0$ & $2.8-6.2$ & $2.5-5.6$ & $3.1-7.0$ & $2.8-6.2$ & $2.5-5.6$ & $4.5-7.0$ & $3.7-4.4$ & $2.5-3.6$ \\
\hline \multirow[t]{2}{*}{ Herd size } & Mean \pm SD & $484 \pm 457$ & $409 \pm 330$ & $311 \pm 275$ & $291 \pm 322$ & $501 \pm 456$ & $412 \pm 272$ & $391 \pm 357$ & $405 \pm 339$ & $407 \pm 407$ \\
\hline & Range & $63-1,609$ & $48-1,343$ & $55-872$ & $55-1,535$ & $48-1,609$ & $73-924$ & $66-1,609$ & $63-1,535$ & $48-1,441$ \\
\hline \multirow[t]{2}{*}{ Group size } & Mean \pm SD & $94 \pm 38$ & $99 \pm 43$ & $116 \pm 62$ & $75 \pm 28$ & $102 \pm 40$ & $133 \pm 57$ & $100 \pm 54$ & $110 \pm 43$ & $99 \pm 52$ \\
\hline & Range & $32-182$ & $44-188$ & $51-267$ & $32-149$ & $44-182$ & $46-267$ & $32-267$ & $51-207$ & $44-227$ \\
\hline \multirow[t]{2}{*}{ Season } & Summer & $15(60 \%)$ & $16(64 \%)$ & 21 (84\%) & 17 (68\%) & $14(56 \%)$ & $21(84 \%)$ & 18 (72\%) & $20(80 \%)$ & $14(56 \%)$ \\
\hline & Winter & $10(40 \%)$ & $9(36 \%)$ & $4(16 \%)$ & $8(32 \%)$ & $11(44 \%)$ & $4(16 \%)$ & $7(28 \%)$ & $5(20 \%)$ & $11(44 \%)$ \\
\hline \multirow[t]{2}{*}{ Milk (ECM) } & Mean & 9,833 & 9,985 & 10,047 & 9,640 & 9,944 & 10,281 & 9,741 & 10,299 & 9,825 \\
\hline & SD & 823 & 764 & 967 & 773 & 824 & 855 & 787 & 729 & 940 \\
\hline \multirow[t]{2}{*}{ Cubicles } & Deep bedded & $16(64 \%)$ & $20(80 \%)$ & $20(80 \%)$ & $14(56 \%)$ & 23 (92\%) & 19 (76\%) & $20(80 \%)$ & 18 (72\%) & $18(72 \%)$ \\
\hline & Rubber mat & $9(36 \%)$ & $5(20 \%)$ & $5(20 \%)$ & $11(44 \%)$ & $2(8 \%)$ & $6(24 \%)$ & $5(20 \%)$ & $7(28 \%)$ & $7(28 \%)$ \\
\hline \multirow[t]{2}{*}{ Floors } & Plain & 17 (68\%) & $14(56 \%)$ & $9(36 \%)$ & $12(48 \%)$ & $17(68 \%)$ & $11(44 \%)$ & 18 (72\%) & $14(56 \%)$ & $8(32 \%)$ \\
\hline & Slatted & 8 (32\%) & 11 (44\%) & $16(64 \%)$ & $13(52 \%)$ & $8(32 \%)$ & $14(56 \%)$ & $7(28 \%)$ & $11(44 \%)$ & $17(68 \%)$ \\
\hline \multirow[t]{2}{*}{ Feeding } & Feed rack & $10(40 \%)$ & $11(44 \%)$ & $15(60 \%)$ & $10(40 \%)$ & $11(44 \%)$ & $15(60 \%)$ & $11(44 \%)$ & $10(40 \%)$ & $15(60 \%)$ \\
\hline & Neck tube & 15 (60\%) & $14(56 \%)$ & $10(40 \%)$ & $15(60 \%)$ & $14(56 \%)$ & $10(40 \%)$ & $14(56 \%)$ & $15(60 \%)$ & $10(40 \%)$ \\
\hline \multirow[t]{2}{*}{ Insulation } & Insulated & $10(40 \%)$ & $12(48 \%)$ & 13 (52\%) & 20 (80\%) & $9(36 \%)$ & $6(24 \%)$ & $9(36 \%)$ & $7(28 \%)$ & 19 (76\%) \\
\hline & Not insulated & 15 (60\%) & $13(52 \%)$ & $12(48 \%)$ & $5(20 \%)$ & $16(64 \%)$ & 19 (76\%) & $16(64 \%)$ & 18 (72\%) & $6(24 \%)$ \\
\hline
\end{tabular}




\subsection{Results}

For the indicator "very lean animals" an effect of herd size was found $(p<0.05)$. The larger the herd size, the lower was the percentage of lean cows. Furthermore, a seasonal effect was investigated within this indicator $(p<0.05)$. Dairy cows had lower amounts of lean cows in summer (11.5 $\pm 0.8 \%)$, compared to winter season (15.5 $\pm 1.2 \%)$. Contrastingly, percentages of severely lame cows were lower in winter $(21.1 \pm 3.4 \%)$, compared to summer season $(34.3 \pm 2.2 \%$; $\mathrm{p}<0.05)$. The avoidance distance test at the feed rack was affected by group size $(p<0.01)$. The larger the group size, the lower the resulting score of the criterion "human-animal relationship". No other significant effects of the covariates herd size and group size or an influence of season were determined for the presented indicators $(p>0.05)$.

\section{Cow-to-stall ratio}

Results of the Welfare Quality ${ }^{\circledR}$ assessment for different cow-to-stall ratios (CSR) are presented in Table 4.9. Trough length per cow was in tendency lower in farms with high CSR. Classes S1 and S2 provided on average more than $6.7 \mathrm{~cm}$ of water surface, compared to $5.6 \mathrm{~cm}$ in class $S 3(p<0.1)$. The frequency of cows lying outside the stall did not differ between class S2 (4.8 $\pm 1.2 \%)$, S1 (3.0 $\pm 1.2 \%)$ and S3 $(2.9 \pm 1.4 \%)(p>0.05)$. The percentages of cows with dirty legs, dirty flanks or dirty udders were comparable between the CSR classes $(p>0.05)$. Within the indicator "severe lameness" an effect of CSR was found $(p<0.05)$. Class S3 had on average $37.7 \pm 3.8 \%$ cows with impaired locomotion, whereas this symptom occurred less often in classes S1 $(22.3 \pm 3.5 \%)$ and S2 $(23.0 \pm 3.2 \%)$. For the indicators "ocular discharge" and "mastitis incidence" no differences were observed ( $p>0.05)$. Also "head butts" were not influenced by CSR $(p>0.05)$, while the number of displacements was in tendency lower in S1 $(0.1 \pm 0.0 \%)$ and S2 $(0.1 \pm 0.0 \%)$ than in S3 $(0.2 \pm 0.0 \%)(p<0.1)$. S1 (81.4 \pm 2.6 points), S2 (82.6 \pm 2.4 points), and S3 (79.1 \pm 2.8 points) achieved comparable scores within the criterion "positive emotions" as assessed by using the qualitative behavior assessment $(p>0.05)$. 
Table 4.9: Results of the Welfare Quality ${ }^{\circledR}$ protocol at the level of indicators and criteria for dairy farms with low (73-95\%), medium (96-103\%) or high (105-133\%) cow-to-stall ratios [N=25; LSMeans; pooled standard error; highlighted $p$-values are significant $(p<0.05)]^{1}$

\begin{tabular}{|c|c|c|c|c|c|c|}
\hline \multirow{2}{*}{\multicolumn{2}{|c|}{ Welfare Indicator / Criteria }} & \multicolumn{3}{|c|}{ Cow-to-Stall Ratio } & \multirow{2}{*}{ PSE } & \multirow{2}{*}{ P-Value } \\
\hline & & $\begin{array}{l}\text { S1 } \\
\text { (low) }\end{array}$ & $\begin{array}{c}\mathrm{S} 2 \\
\text { (medium) }\end{array}$ & $\begin{array}{c}\text { S3 } \\
\text { (high) }\end{array}$ & & \\
\hline \multirow{4}{*}{ 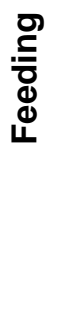 } & Very lean animals (\%) & 13.2 & 14.5 & 12.9 & 1.3 & 0.608 \\
\hline & Trough length/cow $(\mathrm{cm})$ & 6.7 & 7.0 & 5.6 & 0.5 & 0.085 \\
\hline & Lying down duration (sec) & 5.9 & 5.7 & 5.8 & 0.2 & 0.746 \\
\hline & Collision frequency (\%) & 17.5 & 21.9 & 28.6 & 4.2 & 0.421 \\
\hline \multirow{9}{*}{ 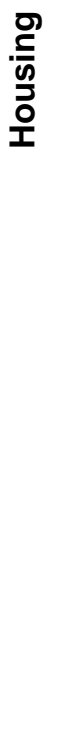 } & Lying outside stalls (\%) & 3.0 & 4.8 & 2.9 & 1.3 & 0.582 \\
\hline & Cows with dirty legs (\%) & 58.3 & 48.2 & 52.3 & 6.2 & 0.420 \\
\hline & Cows with dirty flanks (\%) & 75.9 & 65.9 & 75.0 & 4.0 & 0.183 \\
\hline & Cows with dirty udder (\%) & 38.2 & 38.4 & 34.6 & 4.7 & 0.848 \\
\hline & Severe alterations (\%) & 27.4 & 31.8 & 32.2 & 3.1 & 0.491 \\
\hline & Severe lameness (\%) & 22.3 & 23.0 & 37.7 & 3.5 & 0.008 \\
\hline & Nasal discharge (\%) & 23.4 & 23.5 & 20.5 & 1.7 & 0.553 \\
\hline & Ocular discharge (\%) & 4.5 & 2.3 & 5.0 & 1.1 & 0.060 \\
\hline & Coughing (cow/15 min) & 0.2 & 0.2 & 0.2 & 0.0 & 0.399 \\
\hline \multirow{7}{*}{ 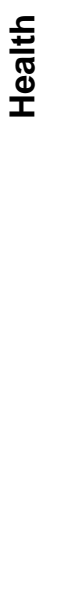 } & Diarrhea incidence (\%) & 31.5 & 36.0 & 38.7 & 3.3 & 0.366 \\
\hline & Mastitis incidence (\%) & 22.9 & 18.2 & 21.9 & 1.7 & 0.082 \\
\hline & Vulvar discharge (\%) & 3.2 & 2.7 & 3.0 & 0.5 & 0.387 \\
\hline & Dystocia rate (\%) & 4.4 & 6.2 & 6.4 & 1.3 & 0.134 \\
\hline & Downer cow rate (\%) & 3.4 & 3.5 & 4.0 & 0.8 & 0.973 \\
\hline & Mortality rate (\%) & 5.9 & 5.3 & 5.2 & 0.8 & 0.971 \\
\hline & Head butts (cow/hour) & 0.4 & 0.3 & 0.5 & 0.1 & 0.477 \\
\hline \multirow{3}{*}{ 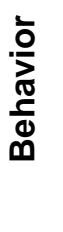 } & Displacements (cow/hour) & 0.1 & 0.1 & 0.2 & 0.0 & 0.078 \\
\hline & Avoidance distance (points) & 74.4 & 74.8 & 79.3 & 2.2 & 0.293 \\
\hline & Positive emotions (points) & 81.4 & 82.6 & 79.1 & 2.6 & 0.649 \\
\hline
\end{tabular}


Table 4.10: Results of the Welfare Quality ${ }^{\circledR}$ protocol at the level of indicators and criteria for dairy farms with low (67-104\%), medium (105-121\%) or high (122-163\%) cow-to-feeding place ratios $[\mathrm{N}=25 \text {; LSMeans; pooled standard error; highlighted } \mathrm{p} \text {-values are significant }(\mathrm{p}<0.05)]^{1}$

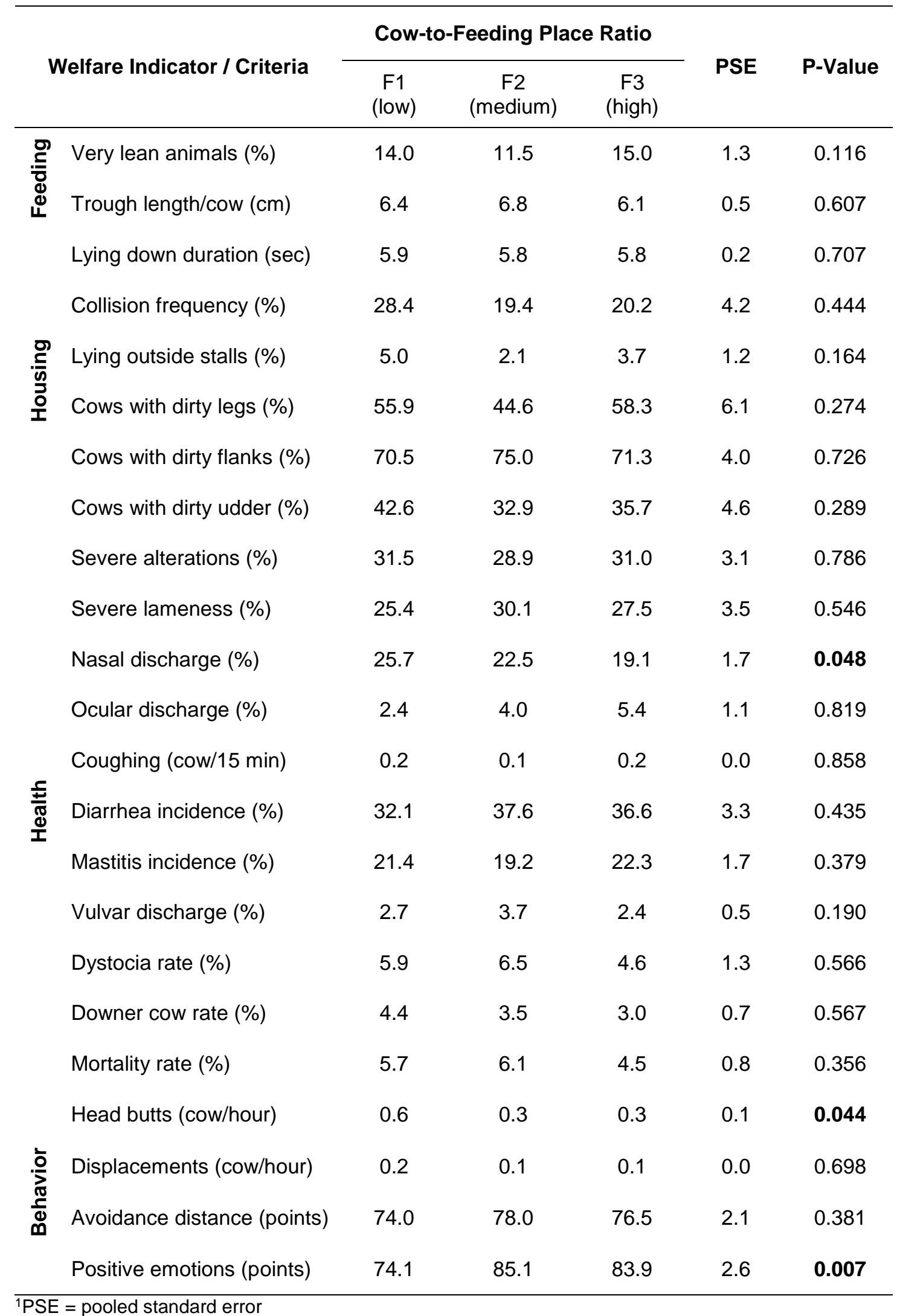


Table 4.11: Results of the Welfare Quality ${ }^{\circledR}$ protocol at the level of indicators and criteria for dairy farms with high (4.5-7.0 $\left.\mathrm{m}^{2}\right)$, medium (3.7-4.4 $\left.\mathrm{m}^{2}\right)$ or low (2.5-3.6 $\left.\mathrm{m}^{2}\right)$ walking space availabilities $[\mathrm{N}=25 \text {; LSMeans; pooled standard error; highlighted } \mathrm{p} \text {-values are significant }(\mathrm{p}<0.05)]^{1}$

\begin{tabular}{|c|c|c|c|c|c|c|}
\hline \multirow{2}{*}{\multicolumn{2}{|c|}{ Welfare Indicator / Criteria }} & \multicolumn{3}{|c|}{ Walking Space Availability } & \multirow{2}{*}{ PSE } & \multirow{2}{*}{ P-Value } \\
\hline & & $\begin{array}{c}\text { W1 } \\
\text { (high) }\end{array}$ & $\begin{array}{c}\text { W2 } \\
\text { (medium) }\end{array}$ & $\begin{array}{l}\text { W3 } \\
\text { (low) }\end{array}$ & & \\
\hline \multirow{4}{*}{ 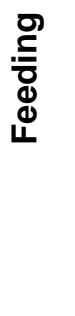 } & Very lean animals (\%) & 15.0 & 13.3 & 12.2 & 1.3 & 0.336 \\
\hline & Trough length/cow (cm) & 7.3 & 6.6 & 5.4 & 0.5 & 0.027 \\
\hline & Lying down duration (sec) & 5.7 & 5.7 & 6.0 & 0.2 & 0.257 \\
\hline & Collision frequency (\%) & 25.5 & 25.4 & 17.0 & 4.1 & 0.486 \\
\hline \multirow{9}{*}{$\begin{array}{l}\text { 옴 } \\
\text { 옴 } \\
\text { 오 }\end{array}$} & Lying outside stalls (\%) & 3.6 & 2.1 & 5.1 & 1.2 & 0.509 \\
\hline & Cows with dirty legs (\%) & 49.2 & 52.1 & 57.5 & 6.0 & 0.608 \\
\hline & Cows with dirty flanks (\%) & 74.7 & 75.5 & 66.6 & 3.9 & 0.339 \\
\hline & Cows with dirty udder (\%) & 34.6 & 35.4 & 41.2 & 4.5 & 0.536 \\
\hline & Severe alterations (\%) & 30.9 & 33.6 & 26.8 & 3.0 & 0.276 \\
\hline & Severe lameness (\%) & 33.1 & 31.2 & 18.8 & 3.4 & 0.007 \\
\hline & Nasal discharge (\%) & 19.8 & 25.2 & 22.4 & 1.7 & 0.088 \\
\hline & Ocular discharge (\%) & 4.4 & 5.4 & 2.1 & 1.1 & 0.073 \\
\hline & Coughing (cow/15 min) & 0.2 & 0.2 & 0.2 & 0.0 & 0.894 \\
\hline \multirow{7}{*}{ 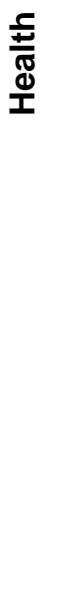 } & Diarrhea incidence (\%) & 37.9 & 36.0 & 32.3 & 3.2 & 0.521 \\
\hline & Mastitis incidence (\%) & 21.4 & 17.8 & 23.7 & 1.6 & 0.036 \\
\hline & Vulvar discharge (\%) & 3.0 & 3.0 & 2.9 & 0.5 & 0.239 \\
\hline & Dystocia rate (\%) & 4.7 & 6.1 & 6.1 & 1.3 & 0.975 \\
\hline & Downer cow rate (\%) & 3.8 & 3.4 & 3.7 & 0.7 & 0.828 \\
\hline & Mortality rate (\%) & 4.9 & 6.4 & 5.1 & 0.8 & 0.419 \\
\hline & Head butts (cow/hour) & 0.4 & 0.4 & 0.5 & 0.1 & 0.104 \\
\hline \multirow{3}{*}{ 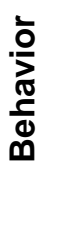 } & Displacements (cow/hour) & 0.1 & 0.1 & 0.2 & 0.0 & 0.303 \\
\hline & Avoidance distance (points) & 76.2 & 76.4 & 75.9 & 2.1 & 0.989 \\
\hline & Positive emotions (points) & 82.9 & 84.4 & 75.8 & 2.5 & 0.057 \\
\hline
\end{tabular}




\section{Cow-to-feeding place ratio}

As shown in Table 4.10, animal welfare indicators of the principle "good feeding" did not differ between cow-to-feeding place ratio (CFR) classes $(p>0.05)$. The percentages of very lean cows were similar in F1 (14.0 $\pm 1.3 \%)$, F2 (11.5 $\pm 1.2 \%)$, and F3 $(15.0 \pm 1.4 \%)$, respectively. Moreover, water provision was comparable in all CFR classes ( $p>0.05)$. An influence of CFR was observed within the indicator "nasal discharge" $(p<0.05)$. Dairy cows of class F1 $(25.7 \pm 1.7 \%)$ showed this symptom more often than those of class F3 $(19.1 \pm 1.8 \%)$. Medium class F2 (22.5 $\pm 1.6 \%$ ) did not differ from both other CFR classes. The indicator "ocular discharge" increased slightly, while the indicator "downer cow rate" decreased slightly with increasing CFR ( $p>0.05)$. In contrast, the number of head butts was influenced by the provided feeding places $(p<0.05)$. Dairy cows of class F1 (0.6 \pm 0.1 ) were more often involved in this type of agonistic interactions, compared to F2 $(0.3 \pm 0.1)$ and F3 $(0.3 \pm 0.1 ; p<0.05)$. However, this effect was not confirmed for the number of displacements $(p>0.05)$. The positive emotional state of the dairy cows was affected by the amount of CFR $(p<0.05)$. Farms of classes $F 1$ (74.1 \pm 2.6 points) obtained on average lower scores within this welfare criterion than those of classes F2 (85.1 \pm 2.4 points) and F3 (83.9 \pm 2.8 points).

\section{Walking space availability}

Results of the animal welfare assessments under different walking space availabilities (WSA) are described in Table 4.11. Percentages of "very lean animals" increased slightly with higher WSA ( $p>0.05)$. Contrastingly, trough length per cow was associated with provided walking spaces $(p<0.05)$. Higher water provisions per cow were measured in class W1 $(7.3 \pm 0.5 \mathrm{~cm})$, compared to class W3 $(5.4$ $\pm 0.5 \mathrm{~cm})$. The medium class $W 2(6.6 \pm 0.5 \mathrm{~cm})$ did not differ from the other classes. For the indicator "severe lameness" an effect of WSA was determined $(p<0.05)$. Dairy cows of class W3 $(18.8 \pm 3.5 \%)$ showed better locomotion scores, compared to those of the classes W2 $(31.2 \pm 3.4 \%)$ and W1 $(33.1 \pm 3.4 \%)$ with larger walking areas. The lowest percentage of "nasal discharge" was in tendency found in W1 $(19.8 \pm 1.6 \%)(p<0.1)$, while the lowest percentage of "ocular discharge" was in tendency investigated in W3 $(2.1 \pm 1.1 \%)(p<0.1)$. The results within the indicator "mastitis incidence" were affected by WSA $(p<0.05)$. Higher rates of mastitis incidences were observed in class W3 (23.7 $\pm 1.7 \%)$, compared 
to class W2 $(17.8 \pm 1.6 \%)$. Results of class W1 $(21.4 \pm 1.6 \%)$ were at a medium level. The highest numbers of head butts and displacements were found in class W3, but the observed agonistic interactions were in total not different between WSA classes $(p>0.05)$. In tendency, results of the qualitative behavior assessment were better in groups with space provisions above $3.7 \mathrm{~m}^{2}$ per cow $(p<0.1)$. Dairy farms of classes W2 (84.4 \pm 2.5 points) and W3 ( $82.9 \pm 2.5$ points) received higher scores compared to class W1 (75.8 \pm 2.6 points).

\subsection{Discussion}

\section{Limitations of the study}

This examination was designed as an overview study to identify potential associations between stocking density and animal welfare in dairy cattle. Due to the multidimensional character of animal welfare (EFSA, 2010), no general relationship between the two factors were expected. Nevertheless, some effects of high stocking densities on single animal welfare indicators are conceivable (e.g., agonistic interactions). Therefore, 75 loose housing dairy cattle farms with zero-pasturing and varying stocking densities were assessed using the Welfare Quality ${ }^{\circledR}$ protocol for dairy cattle. This indicator system provides information on several relevant animal welfare issues (feeding, housing, health, and behavior).

Most of the studies analyzing stocking densities in dairy cattle used experimental designs, so that only short-term effects could be investigated (Chebel et al., 2016; De Vries et al., 2016). Long-term effects of stocking density on the general welfare level should be examined in commercial dairy farms providing different stocking densities (Krawczel et al., 2012b; Proudfoot and Habing, 2015). This practical approach used in the present study is challenging, because the different stocking density parameters (cow-to-stall ratio, cow-to-feeding place ratio and walking space availability) could not be standardized as usually applied in experimental settings. Conceivably, dairy cattle farms with high cow-to-stall ratios might have had low cow-to-feeding place ratios or walking space availabilities. Therefore, the different stocking density parameters could have influenced each other and detrimental effects of one high stocking density parameter could have been compensated by other lower stocking density parameters. 
The classification of the dairy cattle farms into different stocking density groups is another limitation of the present study. They were separated in groups of 25 farms by calculating the tertiles of the selected stocking density parameters in order to examine the effects of low, medium or high stocking densities on animal welfare. Consequently, the distribution of the stocking density groups was relatively diverse. Especially the cow-to-feeding place ratios showed a clear shift to high stocking densities in the present sample, so that the results must be interpreted under consideration of the varying thresholds. For confirmation of the findings, additional linear regression analyses should be conducted, because no classifications are required in this statistical approach. Furthermore, parallel comparisons of different stocking density parameters during statistical analysis usually require correction of p-values (e.g., Bonferroni-Holm) in order to reduce the negative effects of multiple testing. The main objective of the present overview study was the identification of potential associations between stocking density and animal welfare, so the correction of $p$-values was renounced. For future investigations of significant effects of stocking density parameters on animal welfare indicators, p-value correction should be performed. However, under consideration of these limitations the univariate statistical approach might deliver first indications on potential associations of stocking density and animal welfare in dairy cattle. Further research should be conducted using different multivariate statistical approaches in order to improve the understanding of the effects of stocking density parameters on dairy cattle welfare.

Distribution of specific housing conditions (e.g., cubicle types, flooring types and stall climate) was not considered during farm acquisition. No statistical data concerning their proportions in Germany were available, thus it was not possible to compile a representative sample. However, housing conditions were typical for zero-grazing free stall dairy farms and results are therefore relevant for a major part of the German dairy cattle population. Mean herd size of the sample (397 cows) was on a higher level compared to average herd size (61 cows) in Germany (Destatis, 2017). An influence of larger herds was found for the indicator "very lean cows". Lower prevalences were associated with increasing herd size, which confirms previous findings of Adams et al. (2017). The authors stated that larger herds often establish several feeding groups with different rations adjusted 
for specific feeding requirements in particular lactation stages (Adams et al., 2017). Group size had an effect on the results of the avoidance distance test. Increasing group size was related to lower scores within this welfare criterion, indicating that dairy cows are more fearful in larger groups. The highest maximum group sizes were in tendency found in farms with lower numbers of cubicles or feeding places per cow (see Table 4.8). Conceivably, higher competition for limited resources might have increased the stress level within these herds (Proudfoot and Habing, 2015; Chebel et al., 2016) and resulted in stronger reactions towards the human assessor at the feed rack. Seasonal effects were determined for the indicators "very lean cows" and "severe lameness", respectively. Percentage of lean cows was lower in summer assessments, compared to winter assessments. This result is contradictory to de Graaf et al. (2017), who did not observe a clear difference between summer $(4.6 \%)$ and winter $(6.4 \%)$ season $(p>0.05)$. Seasonal calving was not practiced and feeding management (total-mixed ration) was comparable in zero-grazing farms between seasons. Both can therefore be excluded as explanatory factors. Higher prevalences of severely lame cows in summer, compared to winter might be related with higher lameness risks due to prolonged standing times in soiled alleys under heat stress conditions (Webster, 2001; Lombard et al., 2010).

\section{Cow-to-stall ratio}

Percentages of soiled animals were in the present study at a very high level. On average, examined dairy cows had $52.9 \%$ dirty legs, $72.3 \%$ dirty flanks and $37.1 \%$ dirty udders. The dairy farms widely exceeded warning and alarm thresholds for legs $(20 \% ; 50 \%)$, flanks $(10 \% ; 20 \%)$ and udders $(10 \% ; 20 \%)$ stated in the WQP (Welfare Quality, 2012). Comparable results were described by other researchers. Heath et al. (2014) observed $80.6 \%$ dirty legs, $55.5 \%$ dirty flanks and $32.3 \%$ dirty udders, while $88.0 \%$ dirty legs, $52.5 \%$ dirty flanks and $21.8 \%$ dirty udders were found in France (De Boyer des Roches et al., 2014). Higher cow-tostall ratios might affect the cleanliness of dairy cows (Krawczel et al., 2012a). Dairy cows usually avoid wet and dirty stalls, but they are forced to lay down in soiled cubicles under restricted provision of stalls (Fregonesi et al., 2007; Ito et al., 2014). However, results in the present study were not affected by CSR, which 
was in accordance to other studies. Krawczel et al. (2012a) examined the relationship between a balanced (100\%) and a high (142\%) cow-to-stall ratio on several behavior and hygiene parameters. The authors observed no treatment effect on udder and leg hygiene score (Krawczel et al., 2012a). Similarly, Lombard et al. (2010) did not determine any association of the number of dairy cows per 100 stalls on the degree of severe soiling in US dairy farms.

Mean prevalence of severely lame cows $(27.7 \%)$ in the present study was relatively high, compared to previous findings. Heath et al. (2014) determined 4.9\% (0.0 to $47.6 \%$ ) affected cows in the United Kingdom, whereas de Vries et al. (2013) observed $5.0 \%$ (0.0 to 65.9 ) in the Netherlands. Conceivably, lameness prevalence in the present study was influenced by a detrimental combination of several risk factors within the study design (Dippel et al., 2009). Loose housing systems without pasture access are at a high risk of developing claw disorders, because the cows are permanently in contact with soiled alleys. In straw barns, tie stalls and pasture systems lameness occurs less often (Haskell et al., 2006; Espejo and Endres, 2007; Cook et al., 2016). Results of the present study indicated a relationship between high CSR and lameness prevalence. This might be explained by changing behavioral patterns (Espejo and Endres, 2007; Hill et al., 2009). Falk et al. (2012) stated higher standing times in alleys with increasing CSR. Similar results were found by other authors (Fregonesi et al., 2007; Winckler et al., 2015). Inactive standing times in soiled walking areas in turn increase the risk of lameness, because chemical exposures of the manure negatively affect claw health (Webster, 2001).

\section{Cow-to-feeding place ratio}

Results of the present study with $13.5 \%$ lean cows (11.5 to $15.0 \%$ ) are in accordance with other findings. For example, Heath et al. (2014) observed on average $5.7 \%$ in the United Kingdom and Zuliani et al. (2017) detected $18.3 \%$ lean cows in Italy. No effect of CFR on the number of lean cows was investigated in the present study, which confirms the findings of an earlier experiment (Fregonesi and Leaver, 2002). Dairy cows are able to avoid negative effects of an increased CFR on their body condition by shifting their feed intake from the peak after milking to the hours following (Collings et al., 2011). In a recent study, Black et al. 
(2016) compared different CFR $(100,113,131$, and 142\%) regarding several behavioral patterns. No relationship between CFR and feeding behavior (e.g., meals per hour, meal duration) was found by the authors. Similarly, Wang et al. (2016) did not determine differences of feeding time, dry matter intake or feeding rate between lower (82\%) and higher (129\%) CFR.

Higher prevalences of diseases were assumed with increasing stocking densities, because the immune system of the dairy cows can be negatively affected by increasing social stress and intensified contact to other animals (Proudfoot and Habing, 2015; Chebel et al., 2016). This expected association was not confirmed in the present study for indicators of diseases included in the WQP. For example, highest percentages of cows with nasal discharge were observed in F1 (25.7\%) and the lowest in F3 (19.1\%). Conceivably, other housing and management factors are more important for the development of nasal discharge. Dairy cows of F1 were frequently housed in older insulated barns $(80 \%)$, compared to the modern outdoor climate stalls of F3 (76\%). Heat stress might have contributed to a weaker immune status and resulted in higher prevalence of nasal discharge (Kadzere et al., 2002). However, other health indicators (e.g., ocular discharge, coughing, diarrhea, mastitis incidence, and vulvar discharge) were not affected by the number of feeding places per cow $(p>0.05)$.

Lower feed bunk access per cow is usually associated with higher frequencies of agonistic behavior (Chebel et al., 2016). For example, Krawczel et al. (2012b) compared different CFR $(100,113,131$, and $142 \%)$ regarding social behavior at the feed barrier and determined a continuous increase of displacements between treatments. Similarly, Huzzey et al. (2006) observed more displacements from the feeding area, if feed bunk space per cow decreased. Results of the present study are in conflict with the findings reported in the literature. Higher amounts of head butts were found in class F1, compared to the other classes F2 and F3 $(p<0.05)$. The number of displacements did not differ between the CFR groups. These unexpected results might be explained by different methodological approaches. Social interactions were not only assessed the feed bunk, but in different segments of the whole barn (Welfare Quality, 2012). Highest amount of head butts occurred during competition for limited resources such as concentrate 
feeders. These were most commonly used in smaller farms of class F1, whereas larger farms mainly fed a total mixed ration.

The "qualitative behavior assessment" (QBA) approach was included in the WQP to evaluate the emotional state of dairy herds (Welfare Quality, 2012). Higher CFR were associated with higher inactive standing times of dairy cows in the walking alleys, waiting for feed bunk access (Huzzey et al., 2006). This observed behavioral pattern might have negatively affected the emotional state of the animals. Additionally, avoidance of conflicts leads to permanent high stress levels and influences health as well as behavior (Proudfoot and Habing, 2015). Overstocking conditions at the feed bunk might therefore result in a lower positive emotional state in affected herds. Findings of the present study were contradictory to this hypothesis. Lowest QBA scores were found in F1, indicating less positive feelings in the herd. Conceivably, other housing and management factors have a larger negative impact on the emotional state. Farms of class F1 had old, mostly insulated barns and high amounts of rubber mattresses (see Table 4.8). These factors might have contributed to the relatively low average QBA score in the lowest CFR class, because they deemed to impair the welfare of dairy cows (Dippel et al., 2009; Ito et al., 2014).

\section{Walking space availability}

High between-herd variability of water supply was found in the literature. For example, von Keyserlingk et al. (2012) determined in an extensive benchmark study in North American freestall dairies on average 6 to $8 \mathrm{~cm}(1$ to $24 \mathrm{~cm})$ linear water space per cow, which was comparable to findings of the present study. The provided water surfaces per cow differed clearly between the WSA classes. Farms of classes $W 1$ and $W 2$ exceeded the threshold of sufficient $(6 \mathrm{~cm})$ water surface per cow as stated in the WQP. Conversely, farms of class W3 offered partly sufficient (4 to $6 \mathrm{~cm}$ ) water supply (Welfare Quality, 2012). Recorded as a resourcebased parameter, it is however unknown whether each cow has the opportunity to take up enough water to fulfil her daily water requirements. Submissive dairy cows often avoid conflicts with dominant cows, especially in front of limited resources (Proudfoot and Habing, 2015). Therefore, a higher amount of drinkers or troughs, evenly distributed in the barns, are clearly beneficial for the animal welfare level of dairy cows. 
Higher WSA promote locomotion activity of dairy cows and might therefore have positive effects on their health status (Telezhenko et al., 2012). However, previous studies did not find a clear relationship between WSA and lameness prevalence. For example, Dippel et al. (2009) did not determine an effect of the provided movement area $\left(5.9 \pm 1.4 \mathrm{~m}^{2}\right)$ on the number of lame cows in Austria. Similarly, no association between pen space per cow $\left(6.4 \pm 1.3 \mathrm{~m}^{2}\right)$ and lameness was found by Espejo and Endres (2007). Contrastingly, in the present study the fewest number of severely lame cows were found in the lowest WSA class W3. This result can possibly be attributed to the before mentioned behavioral changes under overcrowded conditions. Overcrowding is a social stressor for dairy cattle and whenever possible dairy cows try to avoid competitive situations (Proudfoot and Habing, 2015). Therefore, especially subordinate dairy cows attempt to reduce confrontations by hiding in the stalls (Estevez et al., 2007; Winckler et al., 2015). This avoiding strategy might lead to higher lying times in cubicles and less standing times in soiled walking alleys. Both behavioral changes are beneficial for claw health and might have contributed to reduce the amount of lame cows in this class (Webster, 2001; Espejo and Endres, 2007).

On average, $21.0 \%$ of the dairy cows showed signs of mastitis, determined as somatic cell counts $>400,000$ cells at least once in the last three month (Welfare Quality, 2012). Accordingly, De Boyer des Roches et al. (2014) observed a median of $19.0 \%$ dairy cows with mastitis. Lower incidence rates were found with $11.1 \%$ affected cows in the Netherlands (de Vries et al., 2013) and $15.5 \%$ in the United Kingdom (Heath et al., 2014). Higher prevalences were observed in the present study for dairy farms of class W3, compared to farms of class W2. These results might be explained by higher stress levels under overcrowded conditions, which can lead to immunological responses (Chebel et al., 2016). Additionally, dairy cows are at a higher overall risk of infections due to increased pathogen exposures in farms with less space allowance (Proudfoot and Habing, 2015). Farms of class W3 are also characterized by high cow-to-stall ratios (see Table 4.8). Dairy cows are highly competing for lying areas in overstocked barn situations and especially subordinate cows prefer lying over eating after milking (Hill 
et al., 2009). This behavioral pattern increases the risk of an udder infection, because the teats are physiologically dilated after milking and therefore vulnerable for infections with environmental pathogens (Fregonesi et al., 2007).

\subsection{Conclusions}

Findings of the present study did not indicate a consistent relationship between stocking density and animal welfare in dairy cattle. Consequently, stocking density alone could not be used as an indicator of animal welfare at the herd level. Some animal welfare indicators were better in farms with higher stocking densities, while others were better in farms with lower stocking densities. However, these results were not consistent between stocking density parameters. Different effects on animal welfare indicators of the WQP were determined for cow-to-stall ratio (severe lameness), cow-to-feeding place ratio (nasal discharge, head butts, and positive emotions) or walking space availability (trough length, severe lameness, and mastitis incidence). Therefore, all three types of stocking density parameters should be considered simultaneously for optimizing housing and management in dairy cattle farms. Further studies with larger sample sizes under commercial conditions are necessary to examine potential interactions between the different stocking density parameters.

\subsection{Acknowledgments}

This study was funded by the German Federal Ministry of Education and Research within the project "Sustainable Land Management in North German Lowland" (NaLaMa-nt) and financially supported by the H. Wilhelm Schaumann Foundation. The authors thank the different stakeholders for their support during farm acquisition and the participating farmers for their time and effort. 


\subsection{References}

Adams, A.E., J.E. Lombard, C.P. Fossler, I.N. Román-Muñiz, and C.A. Kopral. 2017. Associations between housing and management practices and the prevalence of lameness, hock lesions, and thin cows on US dairy operations. J. Dairy Sci. 100:2119-2136. https:// doi.org/10.3168/jds.201611517.

Black, R.A., R.J. Grant, and P.D. Krawczel. 2016. Short communication: Shortterm changes in stocking density did not alter meal characteristics of lactating Holstein dairy cattle. J. Dairy Sci. 99:6572-6577. https://doi.org/ 10.3168/jds.2015-9602.

Chebel, R.C., P.R.B. Silva, M.I. Endres, M.A. Ballou, and K.L. Luchterland. 2016. Social stressors and their effects on immunity and health of periparturient dairy cows. J. Dairy Sci. 99:3217-3228. https://doi.org/10.3168/jds.201510369.

Collings, L.K.M., D.M. Weary, N. Chapinal, and M.A.G. von Keyserlingk. 2011. Temporal feed restriction and overstocking increase competition for feed by dairy cattle. J. Dairy Sci. 94:5480-5486. https://doi.org/10.3168/jds. 2011-4370.

Cook, N.B., J.P. Hess, M.R. Foy, T.B. Bennett, and R.L. Brotzman. 2016. Management characteristics, lameness, and body injuries of dairy cattle housed in high-performance dairy herds in Wisconsin. J. Dairy Sci. 99:5879-5891. https://doi.org/10.3168/jds.2016-10956.

De Boyer des Roches, A., I. Veissier, M. Coignard, N. Bareille, R. Guatteo, J. Capdeville, E. Gilot-Fromont, and L. Monier. 2014. The major welfare problems of dairy cows in French commercial farms: an epidemiological approach. Anim. Welf. 23:467-478. https://doi.org/10.7120/09627286.23. 4.467.

De Graaf, S., B. Ampe, and F.A.M. Tuyttens. 2017a. Assessing dairy cow welfare at the beginning and end of the indoor period using the Welfare Quality ${ }^{\circledR}$ protocol. Anim. Welf. 26:213-221. https://doi.org/10.7120/09627286.26.2. 213.

De Vries, A., H. Dechassa, and H. Hogeveen. 2016. Economic evaluation of stall stocking density of lactating dairy cows. J. Dairy Sci. 99:3448-3857. https:// doi.org/10.3168/jds.2015-10556.

De Vries, M., E.A.M. Bokkers, G. van Schaik, R. Botreau, B. Engel, T. Dijkstra, and I.J.M. de Boer. 2013. Evaluating results of the Welfare Quality multicriteria evaluation model for classification of dairy cattle welfare at the herd level. J. Dairy Sci. 96:6264-6273. http://dx.doi.org/10.3168/jds.2012-6129. 
Destatis. 2017. Land- und Forstwirtschaft, Fischerei Rinder- und Schweinebestand Statistisches Bundesamt. Fachserie 3 Reihe 4.1. www.destatis.de/DE/Publikationen/Thematisch/LandForstwirtschaft/ViehbestandTi erischeErzeugung/Viehhaltung2030213169004.pdf?blob=publicationFile (Accessed 07. October 2017).

Dippel, S., M. Dolezal, C. Brenninkmeyer, J. Brinkmann, S. March, U. Knierim, and C. Winckler. 2009. Risk factors for lameness in cubicle housed Austrian Simmental dairy cows. Prev. Vet. Med. 90:102-112. http://dx.doi.org/ 10.1016/j.prevetmed.2009.03.014.

EFSA. 2010. Animal welfare risk assessment guidelines on housing and management. Technical report (EFSA-Q-2009-00844). Wageningen UR Livestock Research. http://www.efsa.europa.eu/en/supporting/pub/en-87. (Accessed 04. November 2017).

Espejo, L.A., and M.I. Endres. 2007. Herd-level risk factors for lameness in highproducing Holstein cows housed in freestall barns. J. Dairy Sci. 90:306314. https://doi.org/10.3168/jds.S0022-0302(07)72631-0.

Estevez, I., I.L. Andersen, and E. Naevdal. 2007. Group size, density and social dynamics in farm animals. Appl. Anim. Beh. Sci. 103:185-204. https://doi. org/10.1016/j.applanim.2006.05.025.

Falk, A.C., D.M. Weary, C. Winckler, and M.A.G. von Keyserlingk. 2012. Preference for pasture versus freestall housing by dairy cattle when stall availability indoors is reduced. J. Dairy Sci. 95:6409-6415. https://doi.org/10. 3168/jds.2011-5208.

Fregonesi, J.A., and J.D. Leaver. 2002. Influence of space allowance and milk yield level on behavior, performance and health of dairy cows housed in strawyard and cubicle systems. Livest. Prod. Sci. 78:245-257. https://doi. org/ 10.1016/S0301-6226(02)00097-0.

Fregonesi, J.A., C.B. Tucker, and D.M. Weary. 2007. Overstocking reduces lying time in dairy cows. J. Dairy Sci. 90:3349-3354. https://doi.org/10.3168/ ids.2006-794.

German Animal Welfare Society. 2018. Animal welfare label - Guidelines for dairy cattle. https://www.tierschutzlabel.info/fileadmin/user_upload/Dokumente/Milchk\%C3\%BChe/Richtlinie_Milchkuehe_2.0.pdf. (Accessed 07. September 2018).

Haskell, M.J., L.J. Rennie, V.A. Bowell, M.J. Bell, and A.B. Lawrence. 2006. Housing system, milk production, and zero-grazing effects on lameness and leg injury in dairy cows. J. Dairy Sci. 89:4259-4266. https://doi.org/ 10.3168/ jds.S0022-0302(06)72472-9. 
Heath, C.A.E., Y. Lin, S. Mullan, W.J. Browne, and D.C.J. Main. 2014. Implementing Welfare Quality ${ }^{\circledR}$ in UK assurance schemes: evaluating the challenges. Anim. Welf. 23, 95-107. https://doi.org/10.7120/09627286.23.1. 095.

Hill, C.T., P.D. Krawczel, H.M. Mann, C.S. Ballard, R.C. Hovey, W.A. Falls, and R.J. Grant. 2009. Effect of stocking density on the short-term behavioural responses of dairy cows. Appl. Anim. Beh. Sci. 117:144-149. https://doi. org/10.1016/j.applanim.2008.12.012.

Huzzey, J.M., T.J. DeVries, P. Valois, and M.A.G. von Keyserlingk. 2006. Stocking density and feed barrier design affect the feeding and social behavior of dairy cattle. J. Dairy Sci. 89:126-133. https://doi.org/10.3168/jds.S00220302(06)72075-6.

Ito, K., N. Chapinal, D.M. Weary, and von M.A.G. Keyserlingk. 2014. Associations between herd-level factors and lying behavior of freestall-housed dairy cows. J. Dairy Sci. 97:2081-2089. https://doi.org/10.3168/jds.2013-6861.

Kadzere, C.T., M.R. Murphy, N. Silanikove, and E. Maltz. 2002. Heat stress in lactating dairy cows: a review. Livest. Prod. Sci. 77:59-91. https://doi.org/ 10.1016/S0301-6226(01) 00330-X.

Krawczel, P.D., C.S. Mooney, H.M. Dann, M.P. Carter, R.E. Butzler, C.S. Ballard, and R.J. Grant. 2012a. Effect of alternative models for increasing stocking density on the short-term behavior and hygiene of Holstein dairy cows. J. Dairy Sci. 95:2467-2475. https://doi.org/10.3168/jds.2011-4686.

Krawczel, P.D., L.B. Klaiber, R.E. Butzler, L.M. Klaiber, H.M. Dann, C.S. Mooney, and R.J. Grant. 2012b. Short-term increases in stocking density affect the lying and social behavior, but not the productivity, of lactating Holstein dairy cows. J. Dairy Sci. 95:4298-4308. https://doi.org/10.3168/jds.20114687.

Lombard, J.E., C.B. Tucker, M.A.G. von Keyserlingk, C.A. Kopral, and D.M. Weary. 2010. Associations between cow hygiene, hock injuries, and free stall usage on US dairy farms. J. Dairy Sci. 93:4668-4676. https://doi.org/ 10.3168/jds.2010-3225.

Proudfoot, K., and G. Habing. 2015. Social stress as a cause of diseases in farm animals: Current knowledge and future directions. Vet. J. 206:15-21. https://doi.org/10.1016/j.tvil.2015.05.024.

Telezhenko, E., M.A.G. von Keyserlingk, A. Talebi, and D.M. Weary. 2012. Effect of pen size, group size, and stocking density on activity in freestall-housed dairy cows. J. Dairy Sci. 95:3064-3069. https://doi.org/10.3168/jds.20114953. 
USDA. 2010. Facility characteristics and cow comfort on U.S. dairy operations. United States Department of Agriculture. http://www.aphis.usda.gov/animal_health/nahms/dairy/downloads/dairy07/Dairy07_ir_Facilities.pdf. (Accessed 07. October 2017).

Von Keyserlingk, M.A.G., A. Barrientos, K. Ito, E. Galo, and D.M. Weary. 2012. Benchmarking cow comfort on North American freestall dairies: Lameness, leg injuries, lying time, facility design, and management for high-producing Holstein dairy cows. J. Dairy Sci. 95:7399-7408. https://doi.org /10.3168/ ids.2012-5807.

Wang, F.X., D.F. Shao, S.L. Li, Y.J. Wang, A. Azarfar, and Z.J. Cao. 2016. Effects of stocking density on behavior, productivity, and comfort indices of lactating dairy cows. J. Dairy Sci. 99:3709-3717. https://doi.org/10.3168/jds.20 15-10098.

Webster, A.J.F. 2001. Effects of housing and two forage diets on the development of claw horn lesions in dairy cows at first calving and in first lactation. Vet. J. 162:56-65. https://doi.org/10.1053/tvjl.2001.0569.

Welfare Quality. 2012. Welfare Quality ${ }^{\circledR}$ Assessment protocol for cattle. Welfare Quality $^{\circledR}$ Consortium, Lelystad, Netherlands. www.welfarequalitynetwork.net/network/45848/7/0/40 (Accessed 21. August 2017).

Winckler, C., C.B. Tucker, and D.M. Weary. 2015. Effects of under- and overstocking freestalls on dairy cattle behavior. Appl. Anim. Beh. Sci. 170:1419. https://doi.org/10.1016/j.applanim.2015.06.003.

Zuliani, A., A. Romanzin, M. Corazzin, S. Salvador, J.C. Abrahantes, and S. Bovolenta. 2017. Welfare assessment in traditional mountain dairy farms: above and beyond resource-based measures. Anim. Welf. 26:203-211. https://doi.org/10.7120/09627286.26.2.203. 


\section{KAPITEL 5}

Effects of Housing and Management on Animal Welfare

Prepared for submission

Animal Welfare 


\title{
Kapitel 5 Effects of Housing and Management on Animal Welfare
}

\author{
Effects of Housing and Management Factors on Animal Welfare Indicators \\ of the Welfare Quality ${ }^{\circledR}$ Protocol in Dairy Cattle Farms
}

\author{
Daniel Gieseke*, Christian Lambertz ${ }^{\dagger}$ and Matthias Gauly ${ }^{\dagger}$ \\ * Department of Animal Sciences, Georg-August-University of Goettingen, Germany \\ + Faculty of Science and Technology, Free University of Bolzano, Italy
}

\subsection{Abstract}

The objective of this study was to examine the effect of housing and management factors on animal welfare indicators in dairy cows using a benchmarking approach. In total, 63 conventional loose housing dairy cattle farms with zero-pasturing were assessed using multiple animal-based measures of the Welfare Quality ${ }^{\circledR}$ protocol (WQP) for dairy cattle. Additionally, housing conditions like barns, cubicles and floors were documented during farm visits and farmers were interviewed concerning their common management routines. Data were recorded from October 2014 to September 2016 by an experienced single assessor in northern Germany. Five indicators of the WQP (very lean cows, lesions/swellings, severe lameness, mastitis incidence, and social behavior) were selected exemplary, because they reflect diverse aspects of animal welfare (feeding, health, and behavior) and variations between farms were greatest for these indicators. Dairy farms were categorized as high welfare groups (HW) and low welfare groups (LW) by calculating upper and lower tertiles for each animal welfare indicator separately. Both groups were compared with regard to provided housing conditions or applied management practices using uni- and multivariable logistic regressions. For each animal welfare indicator several housing and management factors were preselected as potential predictor variables, based on assumed causal associations found in the literature. Preselected variables were analyzed individually with a univariable logistic regression analysis, in order to identify associations between housing and management factors and animal welfare indicators. Higher feeding frequencies (>1 vs. $1 \mathrm{x} /$ day), feeding total mixed ration (vs. 
partly mixed ration), several feeding groups (vs. 1 feeding group) and the amount of concentrate feeding (>8.5 vs. $<8.5 \mathrm{~kg} /$ day) were positively associated with lower percentages of very lean cows $(p<0.20)$. Lower prevalences of severely lame cows were related to medium cow-to-stall ratios (95-105 vs. $<95$ and $>105$ cows/100 stalls), higher frequency of claw trimming (>2.5 vs. $<2.5 \mathrm{x} /$ year), routine use of footbaths (vs. no routine use), solid flooring (vs. slatted flooring) and rubber mats on the floor (vs. no rubber mats) $(p<0.20)$. Lower numbers of animals with high milk somatic cell counts ( $>400,000$ cells $/ \mathrm{ml}$ ) were positively associated with milking in a milking parlor (vs. automatic milking system), lower milking frequency ( 2 vs. $>2$ x/day) and routine use of antibiotic dry cow therapy (vs. on demand) $(p<0.20)$. Associations between lower levels of agonistic interactions and integration of heifers in the herd before calving (vs. after calving), lower cow-to-stall ratios (<95 vs. $\geq 95$ cows/100 stalls), higher feeding alley widths ( $>3.6 \mathrm{~m}$ vs. $<3.6$ $\mathrm{m})$, higher walking spaces per cow $\left(>4.4 \mathrm{~m}^{2} \mathrm{vs} .<4.4 \mathrm{~m}^{2}\right)$, presence of concentrate feeder stations (vs. absence), medium cow-to-feeding place ratios (105-118 vs. $<105$ and >118 cows /100 feeding places) and medium trough length per cow $(4.7-6.8 \mathrm{~cm}$ vs. $<4.7 \mathrm{~cm}$ and $>6.8 \mathrm{~cm})$ were observed $(p<0.20)$. Contrastingly, no associations between the preselected housing and management factors on the prevalences of lesions and swellings were found ( $p>0.20)$. Following, all associated predictor variables with $\mathrm{p}<0.20$ were included in subsequent multivariable logistic regression analyses. However, effects of housing and management factors within the multivariable logistic regression analysis were only determined for severe lameness (routine use of footbaths), mastitis incidence (milking frequency) and social behavior (cow-to-stall ratio) $(p<0.05)$. In conclusion, comparing farms with higher and lower animal welfare performances regarding selected housing and management factors, provide useful information about effective options to improve animal welfare in dairy cattle. However, further research with larger datasets considering different farm types (conventional, organic), housing systems (tie stall, free stall, straw yards) and management options (pasture access, indoor housing) should be conducted to increase explanatory power of this promising benchmarking approach.

Key words: animal welfare, housing, management, dairy cow, Welfare Quality ${ }^{\circledR}$ 


\subsection{Introduction}

Housing conditions (e.g., feeding, resting, and walking area design) are highly relevant for the animal welfare of intensively housed dairy cattle, because they spend most of their lifetime in indoor housing systems (EFSA, 2010; Arnott et al., 2016). In several studies different effects of housing conditions on single animal welfare indicators were examined. For example, Dippel et al. (2009) found a relationship between flooring design and the prevalence of lameness $(p<0.05)$. The risk for lame cows was higher in farms with slatted (Oddds Ratio (OR) 1.3), compared to farms with solid floors (OR 1) (Dippel et al., 2009). In contrast, Solano et al. (2015) investigated no effect of the flooring type on lameness prevalence. Cubicle design can also affect the behavior and health of dairy cows. Higher standing times in cubicles and lower numbers of stall use sessions were found in mattress, compared to deep bedding cubicles (Cook et al., 2004). The latter are also associated with a lower risk of prevalence and severity of hock lesions, due to the softer lying underground (Kester et al., 2014). For example, lower risks of hock lesions were found in cubicles with deep bedding, compared to cubicles without deep bedding (Brenninkmeyer et al., 2013). In addition to the housing conditions in the barns, also management decisions of the farmers can affect the animal welfare level of dairy cows. Wearing gloves during milking occurs more likely in herds having lower bulk milk somatic cell counts $<400,000$ cells $/ \mathrm{ml}$ (Rodrigues et al., 2005), while using coliform mastitis vaccine reduces high bulk milk somatic cell counts (Wenz et al., 2007). Furthermore, routinely administered antibiotics during the dry period decreased the risk of subclinical mastitis in Swiss dairy farms (Doherr et al., 2007). Management decisions of the farmers can also have an impact on the behavior of dairy cows. For example, average frequency of displacements was negatively associated with continuous availability of roughage and introducing heifers before calving in the lactating group (de Vries et al., 2015). Similarly, overstocking (i.e., raising more cows than stalls or feed bunk spaces are available) leads to higher displacement rates at the feed rack (Collings et al., 2011) and prolonged standing times in the walking alleys (Winckler et al., 2015). Most studies examined the influence of housing conditions and management on one or more animal welfare indicators by conducting a risk factor analysis. Dairy farms with lower animal welfare levels regarding lameness (e.g., 
Espejo and Endres, 2007; Dippel et al., 2009), hock lesions (e.g., Lombard et al., 2010; Barrientos et al., 2013), mastitis (e.g., Wenz et al., 2007; Doherr et al., 2007) or displacements (e.g., de Vries et al., 2016) were compared with larger control groups. Because of the study design the discriminatory power between both groups compared might have been relatively small and consequently potential influencing factors may have been undetected. Therefore, the objective of the present study was to compare dairy farms showing larger variations within selected animal welfare indicators (very lean cows, lesions/swellings, severe lameness, mastitis incidence, and social behavior) using a benchmarking approach. Dairy farms were categorized as high welfare groups (HW) and low welfare groups (LW) by calculating upper and lower tertiles for each animal welfare indicator separately and compared with regard to their housing conditions or management practices. A total of 63 conventional loose housing dairy cattle farms with zero-pasturing were assessed using multiple animal-based measures of the Welfare Quality ${ }^{\circledR}$ protocol (WQP) for dairy cattle. Additionally, housing conditions like barn, cubicle and floor design were recorded during farm visits and dairy farmers were interviewed concerning their common management routines.

\subsection{Material and Methods}

\section{Study Design}

Data collection was conducted from October 2014 to September 2016 by a single experienced assessor on 63 conventional dairy farms located in northern Germany. Each farm was visited 2 times at an interval of 6 months (summer period and winter period) to avoid seasonal effects on the animal welfare assessment. The animal welfare level was assessed using the WQP. This is a standardized indicator system for on-farm animal welfare assessment. It focuses mainly on animal-based measures, which directly reflect the actual welfare state of the animals. More than 30 animal welfare indicators from the fields of feeding, housing, health and behavior were measured and aggregated to 12 welfare criteria and 4 welfare principles (Welfare Quality, 2012). The assessor was trained intensively by a member of the Welfare Quality ${ }^{\circledR}$ Network to ensure the correct application of the WQP. The official four-day training course consisted of theoretical exercises with photos and videos as well as practical applications of the WQP on different 
dairy cattle farms. The whole Welfare Quality ${ }^{\circledR}$ Assessment protocol was conducted on each dairy farm. Indicators with the largest variations were used for subsequent statistical analysis in the present study, indicating potential influencing effects of housing and management factors. Five indicators representing different aspects of animal welfare were selected (lean cows, lesions/swellings, severe lameness, somatic cell count, and agonistic interactions).

\section{Farm Selection}

Farm acquisition was organized with the support of different agricultural stakeholders (e.g., chamber of agriculture, milk recording association and research facilities). For participation in the study some specific requirements had to be fulfilled to guarantee the comparability of the housing environment. All lactating dairy cows in the sample had to be kept in loose housing barns with deep bedded or rubber mat-equipped cubicles. The dominant breed was Holstein Friesian, so that genetic effects could be excluded. Farms with access to pasture for more than six hours per day were omitted from the study, because this resource-based indicator has a high weighting within the aggregation system of the WQP and an inclusion would lead to a substantial confounding effect. There were no other limitations regarding housing conditions, milking techniques or feeding systems (for further characterizations of the farms see Table 5.12).

Table 5.12: Farm characteristics (mean, standard deviation, minimum, maximum) and housing conditions (number of farms, percentage of farms) of 63 dairy cattle farms. ${ }^{1}$

\begin{tabular}{|c|c|c|c|c|c|c|c|}
\hline \multicolumn{4}{|c|}{ Farm characteristics } & & \multicolumn{3}{|c|}{ Housing conditions } \\
\hline Parameter & Mean \pm SD & Min & Max & & Barn design & Number & Amount \\
\hline Herd size & $368 \pm 346$ & 45 & 1,609 & $\frac{\mathscr{0}}{0}$ & Deep bedded & 46 & $73 \%$ \\
\hline Group size & $99 \pm 46$ & 32 & 237 & $\vec{J}$ & Rubber mat & 17 & $27 \%$ \\
\hline Hectar/cow & $2.4 \pm 2.4$ & 0.3 & 14.3 & $\stackrel{\infty}{0}$ & Plain & 32 & $51 \%$ \\
\hline Milk & $9,915 \pm 943$ & 6,870 & 11,805 & $\frac{0}{4}$ & Slatted & 31 & $49 \%$ \\
\hline Fat & $4.0 \pm 0.2$ & 3.6 & 4.5 & $\stackrel{\text { D }}{=}$ & Feed rack & 30 & $48 \%$ \\
\hline Protein & $3.4 \pm 0.1$ & 3.2 & 3.6 & $\stackrel{\varpi}{\leftarrow}$ & Neck tube & 33 & $52 \%$ \\
\hline ECM & $9,880 \pm 914$ & 7,091 & 11,747 & $\frac{c}{\stackrel{0}{0}}$ & Insulated & 32 & $51 \%$ \\
\hline BTSCC & $249 \pm 78$ & 88.0 & 417.0 & की & Not insulated & 31 & $49 \%$ \\
\hline
\end{tabular}

${ }^{1}$ Group size = largest number of cows in a group; ECM = energy corrected milk; BTSCC = bulk tank somatic cell count; SD = standard deviation 


\section{Data Collection}

Animal welfare assessments were conducted following the instructions of the WQP for dairy cattle (Welfare Quality, 2012). Minor modifications were made for practical or statistical reasons (e.g., non-lactating cows and cows in hospital pens were excluded). Modified animal welfare indicators and assessment methods executed on 85 dairy farms are described in Table 5.13. Twenty-two farms were excluded due to missing information on management practices. Datasets of the 63 dairy cattle farms were complete for all measures of the WQP (2 ${ }^{\text {nd }}$ farm visit).

The farm visits usually started at 8 am $( \pm 1 \mathrm{~h})$ after morning milking and lasted, depending on herd size, 6 to 13 hours. Data collection was performed at each farm in a fixed order. At the beginning of the farm visit, agonistic interactions between cows were recorded using continuous behavior sampling. Behavioral observations took place in up to 12 different segments of the barn (with a maximum of 25 dairy cows per segment). The clinical scoring of individual dairy cows was carried out in a sample according to group size, if animals were kept in different groups. All measures were recorded in the same sample of animals (body condition, integument alterations, and lameness). Depending of the herd size a sample of 32 to 102 cows were assessed at each farm visit.

Finally, milk-recording data (milk somatic cell count) of the last three month before farm visit were gathered during a farmer interview. In addition to the indicators of the WQP, farm characteristics like barn, cubicle and floor design or feeding system were recorded at the second farm visit according to von Keyserlingk et al. (2012). Cubicle dimensions including bed length from curb to brisket locator, neck rail distance from the rear curb, neck rail height from the bedding, and average distance from stall partition to bedding were recorded exemplary on 2 to 5 stalls in each dairy farm (depending of uniformity of the stalls). Stall width was measured as the distance between two adjacent stall partitions on at least 10 stalls, because stall width differed more frequent compared to other stall dimensions. Double-row cubicles and cubicles against walls were surveyed separately and average stall dimensions were weighted according to their presence in the different pens of the lactating dairy cows. 
Table 5.13: Data collected for the assessment of the animal welfare level of lactating dairy cows using the Welfare Quality ${ }^{\circledR}$ protocol for dairy cattle (modified by Coignard et al., 2013).

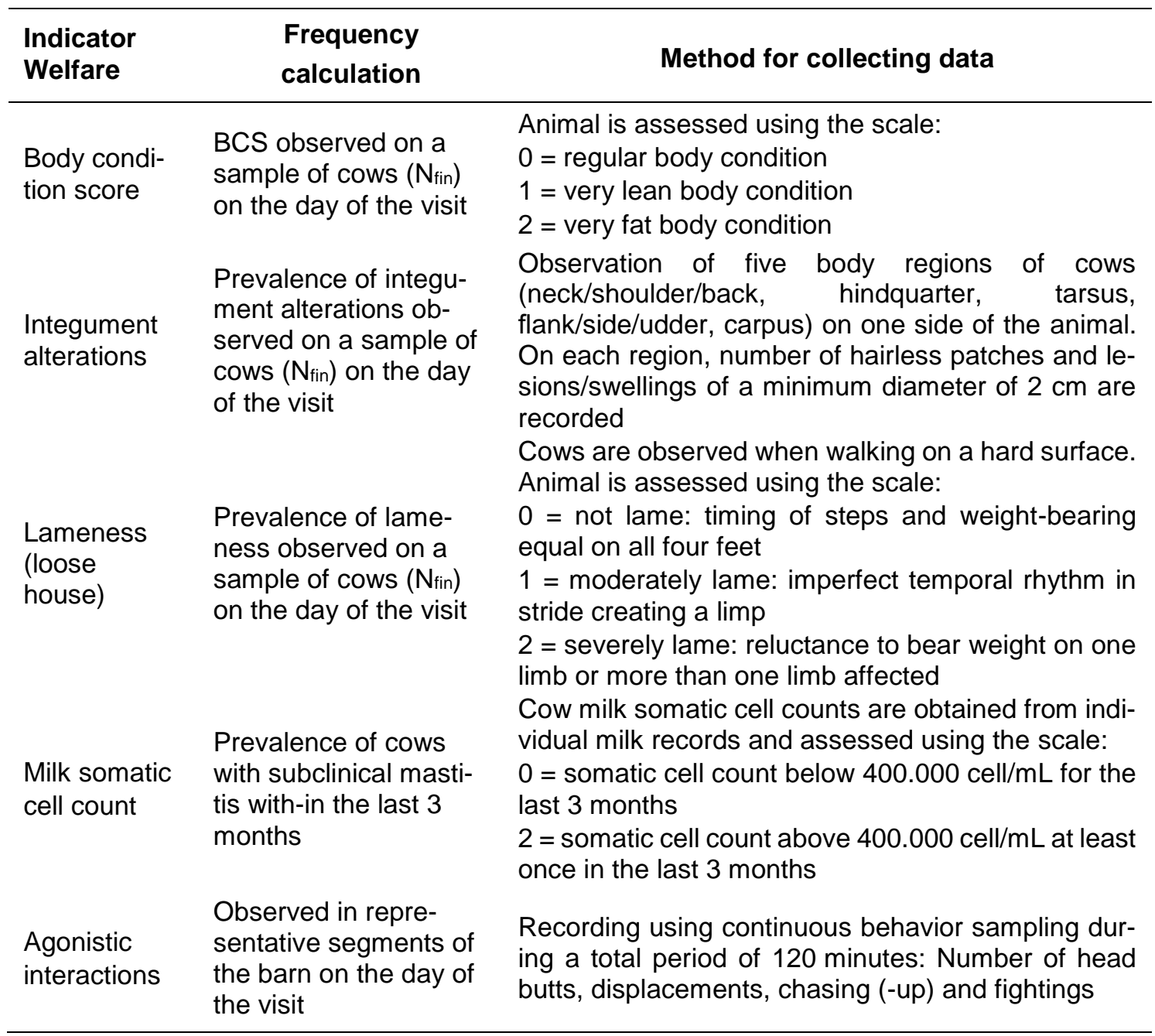

Type of stall type (deep bedded, rubber mat), presence of brisket locator, flooring type (slatted floor, plain floor), presence of rubber mats on the floors, type of feeding barrier (neck rail, feed racks), stall climate equipment (curtains, ventilators), barn equipment (concentrate feeder, cow brushes) or barn construction (insulated, non-insulated) were recorded through direct observation. Cow-to-stall ratio was calculated by counting animals and stalls in each group of lactating dairy cows $(>100 \%=$ overstocking; $<100 \%=$ understocking). Cow-to-feeding place ratio was calculated by assessing the number of feed racks and the number of dairy cows per group. In farms with neck tubes, length of the feed alley was measured and divided by $0.6 \mathrm{~m}$ to estimate the cow-to-feeding place ratio as proposed by von Keyserlingk et al. (2012). Surfaces of walking alleys, feed alleys, crossovers and, if appropriate, loafing yards were summed up and divided by the number of dairy cows per group to calculate the provided walking space abilities 
$\left(\mathrm{m}^{2}\right)$. Trough lengths as well as average widths of alleys and crossovers were measured separately for each pen. Recorded values were weighted by the number of dairy cows in each lactation group, because housing conditions and group sizes partly differed within the farms. Management practices from the fields of feeding management (e.g., amount of concentrates per cow, feeding frequency, body condition scoring), cleaning management (e.g., cleaning frequency of cubicles, walking alleys), milking procedures (e.g., milking frequency, milking system, post-dip) or health management (e.g., claw trimming, claw bath, dry cow therapy with antibiotics) were obtained through farmer interviews.

\section{Statistical Analysis}

Results of the WQP were inspected for the highest variations within the animal welfare indicators, because high variability between dairy farms indicate potential influencing effects of housing and management factors. Five indicators were selected (very lean cows, lesions/swellings, severe lameness, milk somatic cell count, and agonistic interactions). Prevalences of the selected welfare indicators were dichotomized by calculating tertiles. The upper tertile of the 63 dairy farms represents higher welfare, while the lower tertile of the dairy farms represents lower welfare within each indicator. The remaining farms of the medium tertile were not considered in statistical analysis in order to improve the discriminatory power. The indicators very lean cows, lesions/swellings, severe lameness, and milk somatic cell count were expressed as percentage of affected cows (\%). The welfare indicators head butts and displacements were aggregated to the criterion "social behavior" using I-spline-functions as described in the WQP. Criterion scores are expressed on a 0 to 100 value scale $(0=$ poor, $100=$ good). Accordingly, upper and lower tertiles were calculated with the particular scores. All statistical analyses were computed with SAS, version 9.4 (Statistical Analysis Systems, Cary, NC, USA). Dairy farms with higher and lower welfare levels within each indicator (response variable) were compared regarding several housing and management factors (predictor variables) using a logistic regression analysis (Proc logistic). Continuous housing (e.g., stall dimensions, trough length) and management (e.g., amount of concentrates, cow-to-stall ratio) variables were categorized using tertiles. For each animal welfare indicator several housing and 
management factors were selected as potential predictors. The preselection process was based on assumed causal associations between response and predictor variables found in the literature or our own observations during farm visits. First, collinearity between all housing and management factors was checked using Pearson's Chi-square test of independence. Phi Coefficient or Cramer's V (depending on amount of categories) were calculated to assess the effect size. The threshold for collinearity was set at 0.80 , but no variable combination within the data set exceeded this value. Each preselected housing and management factor was analyzed individually with a logistic regression analysis, in order to identify associations between predictor and response variables. Odds ratios and $95 \%$ confidence intervals were calculated to describe the probability of each herd being in the higher welfare group. All predictor variables with $p<0.20$ were included in subsequent multivariable statistical analyses. The final logistic regression models were fitted using automated stepwise selection procedure. The statistical procedure adds or removes variables to the model considering a significance level of $p<0.05$. Standardized deviance residuals were examined visually.

Table 5.14: Classification of groups with high animal welfare (HW; upper tertile) and low animal welfare (LW; lower tertile) within specific animal welfare indicators or criteria (very lean cows, lesions/swellings, severe lameness, mastitis incidence, and social behavior); levels = thresholds for upper and lower tertiles [Mean, standard deviation, minimum, maximum]. ${ }^{1}$

\begin{tabular}{|c|c|c|c|c|c|c|}
\hline $\begin{array}{l}\text { Indicator/ } \\
\text { criterion }\end{array}$ & Group & Level & Mean & SD & Min & Max \\
\hline \multirow{2}{*}{$\begin{array}{l}\text { Very lean cows } \\
(\%)\end{array}$} & HW & $<9.2$ & 6.3 & 2.3 & 0.0 & 9.1 \\
\hline & LW & $>15.6$ & 19.9 & 4.1 & 15.9 & 29.2 \\
\hline \multirow{2}{*}{$\begin{array}{l}\text { Lesions/swellings } \\
(\%)\end{array}$} & $\mathrm{HW}$ & $<27.1$ & 16.5 & 6.5 & 6.3 & 27.1 \\
\hline & LW & $>38.0$ & 47.4 & 6.9 & 38.6 & 62.7 \\
\hline \multirow{2}{*}{$\begin{array}{l}\text { Severe lameness } \\
(\%)\end{array}$} & HW & $<22.0$ & 11.9 & 6.0 & 0.0 & 21.9 \\
\hline & LW & $>37.0$ & 52.9 & 11.7 & 37.5 & 74.3 \\
\hline \multirow{2}{*}{$\begin{array}{l}\text { Mastitis incidence } \\
(\%)\end{array}$} & $\mathrm{HW}$ & $<18.0$ & 13.0 & 4.6 & 2.3 & 17.6 \\
\hline & LW & $>22.5$ & 27.6 & 4.0 & 22.8 & 37.4 \\
\hline \multirow{2}{*}{$\begin{array}{l}\text { Social behavior } \\
\text { (points) }\end{array}$} & HW & $>90.0$ & 92.6 & 1.9 & 90.1 & 96.6 \\
\hline & LW & $<83.5$ & 71.6 & 13.7 & 40.4 & 83.0 \\
\hline
\end{tabular}




\subsection{Results}

Characterization of dairy farms with higher or lower animal welfare levels within specific indicators of the Welfare Quality ${ }^{\circledR}$ Assessment are shown in Table 5.14. Based on the calculation of tertiles from the results of the welfare assessments, farms were classified as having lower welfare levels (LW), when they exceed the threshold of $15.6 \%$ lean cows. Contrastingly, farms with less than $9.2 \%$ lean cows were classified as having higher welfare levels (HW). On average, $13.0 \%$ lean cows were determined within the present study. In group HW $6.3 \%$ (0.0 to 9.1) lean cows were found, while $19.9 \%$ (15.9 to 29.2) were determined in group LW. The mean percentages of lesions and swellings were 16.5\% (6.3 to 27.1) in group HW and $47.4 \%$ (38.6 to 62.7 ) in group LW, respectively.

Farms of group HW had on average $11.9 \%$ (0.0 to 21.9 ) severely lame cows, whereas $52.9 \%$ (37.5 to 74.3 ) were detected in group LW. Dairy cows within group HW showed on average $13.0 \%$ (2.3 to 17.6) high milk somatic cell counts. In the lower welfare group LW $27.6 \%$ (22.8 to 37.4 ) cows with signs of mastitis were found. The welfare criterion "social behavior" is calculated by the number of recorded head butts and displacements (per cow and hour). Farms with higher welfare levels within this criterion had average scores of 92.6 points (90.1 to 96.6). Contrastingly, farms of group LW achieved with 71.6 points ( 40.4 to 83.0 ) lower scores.

\section{Very lean cows}

The results for the indicator "very lean cows" are shown in Table 5.15. In total, 10 preselected housing and management variables were considered as potential influencing factors in univariable statistical analysis. Four variables were associated with being a high welfare level herd (HW), indicating lower percentages of lean cows. Higher feeding frequencies ( $>1$ vs. $1 \mathrm{x} /$ day), feeding total mixed ration (vs. partly mixed ration), several feeding groups (vs. 1 feeding group) and the amount of concentrate feeding ( $>8.5 \mathrm{vs}$. $<8.5 \mathrm{~kg} /$ day) were positively associated with lower percentages of very lean cows $(p<0.20)$ and therefore included in subsequent statistical analyses. None of the tested variables was significant in the multivariable logistic regression analysis $(p>0.05)$. 


\section{Lesions/Swellings}

The results for the indicator "lesions/swellings" are shown in Table 5.16. In total, 10 preselected housing and management variables were considered as potential influencing factors in univariable statistical analysis. No variables were associated with being a high welfare level herd $(\mathrm{HW})$, indicating lower percentages of cows with severe integument alterations such as lesions or swellings $(p>0.20)$. Therefore, none of the preselected variables had been tested in a subsequent multivariable logistic regression analysis.

\section{Severe Lameness}

The results for the indicator "severe lameness" are shown in Table 5.17. In total, 11 preselected housing and management variables were considered as potential influencing factors in univariable statistical analysis. Five variables were associated with being a high welfare level herd $(\mathrm{HW})$, indicating lower percentages of severe lame cows. Medium cow-to-stall ratio $(95-105 \%$ vs. $<95 \%$ and $>105 \%)$, high frequency of claw trimming ( $>2.5 \mathrm{vs}$. $<2.5 \mathrm{x} /$ year), routine use of footbaths (vs. no routine use), solid floors (vs. slatted floors) and presence of rubber mats on the floor (vs. no presence of rubber mats) were positively associated with lower percentages of severe lame cows $(p<0.20)$ and therefore included in subsequent statistical analyses. Routine use of footbaths was significant in the multivariable logistic regression analysis $(\mathrm{p}<0.05)$. The final model reached a coefficient of determination of $r^{2}=0.10$ (i.e., $10 \%$ of the variance could be explained by the fitted model).

\section{Mastitis Incidence}

The results for the indicator "mastitis incidence" are shown in Table 5.18. In total, 12 preselected housing and management variables were considered as potential influencing factors in univariable statistical analysis. Three variables were associated with being a high welfare level herd $(\mathrm{HW})$, indicating lower percentages of cows with high milk somatic cell counts $(>400,000$ cells $/ \mathrm{ml}$ ). Milking in a milking parlor (vs. automatic milking systems), lower milking frequency ( 2 vs. $>2$ x/day) and on demand dry cow antibiotic therapy (vs. routinely) were positively associated with lower percentages of mastitis incidence $(p<0.20)$ and therefore included in subsequent statistical analyses. Frequency of milking was significant in the 
multivariable logistic regression analysis $(\mathrm{p}<0.05)$. The final model reached a coefficient of determination of $r^{2}=0.13$ (i.e., $13 \%$ of the variance could be explained by the fitted model).

\section{Social Behavior}

The results for the criterion "social behavior" are shown in Table 5.19. In total, 12 preselected housing and management variables were considered as potential influencing factors in univariable statistical analysis. Seven variables were associated with being a high welfare level herd $(\mathrm{HW})$, indicating lower agonistic interactions between dairy cows. Integration of heifers in the herd before calving (vs. after calving), lower cow-to-stall ratios (<95\% vs. >95\%), higher feeding alley widths (>3.6 m vs. $<3.6 \mathrm{~m})$, higher walking spaces per cow $\left(>4.4 \mathrm{~m}^{2}\right.$ vs. $\left.<4.4 \mathrm{~m}^{2}\right)$, Presence of concentrate feeder stations (vs. absence of concentrate feeder stations), medium cow-to-feeding place ratios (105-118\% vs. $<105 \%$ and $>118 \%$ ) and medium trough length per cow $(4.7-6.8 \mathrm{~cm}$ vs. $<4.7$ and $>6.8 \mathrm{~cm})$ were positively associated with lower agonistic interactions between dairy cows $(p<0.20)$ and therefore included in subsequent statistical analyses. Cow-to-stall ratio was significant in the multivariable logistic regression analysis $(p<0.05)$. The final model reached a coefficient of determination of $r^{2}=0.18$ (i.e., $18 \%$ of the variance could be explained by the fitted model). 
Table 5.15: Potential influencing factors in univariable logistic regression analysis associated with being a herd with high welfare level $(\mathrm{HW})$ within the indicator "very lean cows" [Odds ratio, Confidence interval, bold $p$-values $(p<0.20)$ were included in multivariable analyses; final model presented at the bottom of the table]. ${ }^{1}$

\begin{tabular}{|c|c|c|c|c|c|c|}
\hline $\begin{array}{l}\text { Potential influencing } \\
\text { factors }\end{array}$ & Level & LW & HW & OR & $95 \% \mathrm{Cl}$ & $\mathbf{P}$ \\
\hline \multirow{2}{*}{$\begin{array}{l}\text { Feeding frequency } \\
\text { (times/day) }\end{array}$} & 1 & 11 & 6 & 0.390 & $0.108 ; 1.407$ & 0.150 \\
\hline & $>1$ & 10 & 14 & 1 & - & \\
\hline \multirow{3}{*}{$\begin{array}{l}\text { Pushing of feed } \\
\text { (times/day) }\end{array}$} & $<4$ & 7 & 6 & 0.571 & $0.108 ; 3.036$ & 0.717 \\
\hline & $4-6$ & 10 & 8 & 0.533 & $0.111 ; 2.564$ & \\
\hline & $>6$ & 4 & 6 & 1 & - & \\
\hline \multirow{3}{*}{$\begin{array}{l}\text { Calculation of rations } \\
\text { (times/year) }\end{array}$} & $<4$ & 7 & 4 & 0.571 & $0.108 ; 3.036$ & 0.599 \\
\hline & $4-11$ & 7 & 9 & 1.286 & $0.286 ; 5.774$ & \\
\hline & $>11$ & 6 & 6 & 1 & - & \\
\hline \multirow[t]{2}{*}{ Calculation of feed remains } & No & 5 & 3 & 0.565 & $0.116 ; 2.758$ & 0.480 \\
\hline & Yes & 16 & 17 & 1 & - & \\
\hline \multirow{3}{*}{$\begin{array}{l}\text { Body condition scoring } \\
\text { (times/lactation) }\end{array}$} & $<1$ & 6 & 4 & 0.667 & $0.129 ; 3.446$ & 0.803 \\
\hline & $1-3$ & 7 & 8 & 1.143 & $0.266 ; 4.913$ & \\
\hline & $<4$ & 7 & 7 & 1 & - & \\
\hline \multirow[t]{2}{*}{ Feeding regime } & PMR & 6 & 1 & 0.125 & $0.868 ; 73.613$ & 0.066 \\
\hline & TMR & 15 & 20 & 1 & - & \\
\hline \multirow{2}{*}{$\begin{array}{l}\text { Feeding groups } \\
\text { (rations) }\end{array}$} & 1 & 11 & 4 & 0.227 & $0.057 ; 0.913$ & 0.037 \\
\hline & $>1$ & 10 & 16 & 1 & - & \\
\hline \multirow{3}{*}{$\begin{array}{l}\text { Amount of staple feed } \\
(\%)\end{array}$} & $>66$ & 6 & 3 & 0.300 & $0.054 ; 1.669$ & 0.386 \\
\hline & $61-66$ & 4 & 4 & 0.600 & $0.108 ; 3.338$ & \\
\hline & $<60$ & 6 & 10 & 1 & - & \\
\hline \multirow{3}{*}{$\begin{array}{l}\text { Amount of concentrates } \\
\text { (kg/day) }\end{array}$} & $<6.9$ & 6 & 2 & 0.111 & $0.016 ; 0.778$ & 0.085 \\
\hline & $6.9-8.5$ & 4 & 7 & 0.519 & $0.104 ; 2.581$ & \\
\hline & $>8.5$ & 6 & 9 & 1 & - & \\
\hline \multirow{3}{*}{$\begin{array}{l}\text { Cow-to-feeding place ratio } \\
(\%)\end{array}$} & $>118$ & 7 & 4 & 0.762 & $0.151 ; 3.856$ & 0.286 \\
\hline & $105-118$ & 6 & 11 & 2.444 & $0.572 ; 10.447$ & \\
\hline & $<105$ & 8 & 6 & 1 & - & \\
\hline
\end{tabular}

No effects for selected housing and management variables were found in the final model ( $p>0.05)$

${ }^{1}$ Number of herds included in logistic regression models were partly lower than $n=21$, because single housing and management factors were not available for some herds. PMR $=$ Partial mixed ration, TMR $=$ total mixed ration. 
Table 5.16: Potential influencing factors in univariable logistic regression analysis associated with being a herd with high welfare level $(\mathrm{HW})$ within the indicator "lesions/swellings" [Odds ratio, confidence interval, bold $p$-values $(p<0.20)$ were included in multivariable analyses; final model presented at the bottom of the table]. ${ }^{1}$

\begin{tabular}{|c|c|c|c|c|c|c|}
\hline $\begin{array}{l}\text { Potential influencing } \\
\text { factors }\end{array}$ & Level & LW & HW & OR & $95 \% \mathrm{Cl}$ & $\mathbf{P}$ \\
\hline \multirow[t]{2}{*}{ Cubicle types } & $\mathrm{RM}$ & 4 & 4 & 1.000 & $0.214 ; 4.666$ & 1.000 \\
\hline & DB & 17 & 17 & 1 & - & \\
\hline \multirow{3}{*}{$\begin{array}{l}\text { Cubicle cleaning } \\
\text { (times/day) }\end{array}$} & 1 & 5 & 5 & 1.000 & $0.123 ; 8.128$ & 1.000 \\
\hline & 2 & 14 & 14 & 1.000 & $0.098 ; 10.166$ & \\
\hline & 3 & 2 & 2 & 1 & - & \\
\hline \multirow{3}{*}{$\begin{array}{l}\text { Mean cubicle width } \\
(\mathrm{cm})\end{array}$} & $<110$ & 8 & 8 & 1.800 & $0.415 ; 7.814$ & 0.303 \\
\hline & $110-113$ & 4 & 8 & 3.599 & $0.710 ; 18.251$ & \\
\hline & $>113$ & 9 & 5 & 1 & - & \\
\hline \multirow{3}{*}{$\begin{array}{l}\text { Mean cubicle length } \\
(\mathrm{cm})\end{array}$} & $<186$ & 6 & 3 & 0.563 & $0.105 ; 3.023$ & 0.368 \\
\hline & $186-195$ & 6 & 10 & 1.875 & $0.467 ; 7.526$ & \\
\hline & $>195$ & 9 & 8 & 1 & - & \\
\hline \multirow{3}{*}{$\begin{array}{l}\text { Mean distance neck rail - } \\
\text { curb }(\mathrm{cm})\end{array}$} & $<197$ & 7 & 11 & 2.750 & $0.583 ; 12.976$ & 0.372 \\
\hline & 197-205 & 7 & 5 & 1.250 & $0.233 ; 6.714$ & \\
\hline & $>205$ & 7 & 4 & 1 & - & \\
\hline \multirow[t]{2}{*}{ Presence of brisket locator } & Yes & 15 & 17 & 1.700 & $0.402 ; 7.198$ & 0.471 \\
\hline & No & 6 & 4 & 1 & - & \\
\hline \multirow{3}{*}{$\begin{array}{l}\text { Mean height neck rail } \\
(\mathrm{cm})\end{array}$} & $<113$ & 6 & 9 & 2.000 & $0.456 ; 8.777$ & 0.621 \\
\hline & $113-119$ & 7 & 6 & 1.143 & $0.250 ; 5.224$ & \\
\hline & $>119$ & 8 & 6 & 1 & - & \\
\hline \multirow{3}{*}{$\begin{array}{l}\text { Mean height feeding place } \\
\text { (cm) }\end{array}$} & $<129$ & 8 & 3 & 0.234 & $0.041 ; 1.328$ & 0.224 \\
\hline & $129-140$ & 8 & 10 & 0.781 & $0.183 ; 3.342$ & \\
\hline & $>140$ & 5 & 8 & 1 & - & \\
\hline \multirow[t]{2}{*}{ Feeding rack type } & NR & 12 & 9 & 0.563 & $0.166 ; 1.910$ & 0.356 \\
\hline & $\mathrm{HL}$ & 9 & 12 & 1 & - & \\
\hline \multirow[t]{2}{*}{ Feeding place inclined } & Yes & 9 & 11 & 1.467 & $0.434 ; 4.951$ & 0.537 \\
\hline & No & 12 & 10 & 1 & - & \\
\hline
\end{tabular}

No effects for selected housing and management variables were found in the final model ( $p>0.05)$

${ }^{1}$ Number of herds included in logistic regression models were partly lower than $n=21$, because single housing and management factors were not available for some herds. $\mathrm{RM}=$ rubber mats, $\mathrm{DB}=$ deep-bedded, NR = neck rail, $\mathrm{HL}=$ head lock. 
Table 5.17: Potential influencing factors in univariable logistic regression analysis associated with being a herd with high welfare level $(\mathrm{HW})$ within the indicator "severe lameness" [Odds ratio, Confidence interval, bold $p$-values $(p<0.20)$ were included in multivariable analyses; final model presented at the bottom of the table]. ${ }^{1}$

\begin{tabular}{|c|c|c|c|c|c|c|}
\hline $\begin{array}{l}\text { Potential influencing } \\
\text { factors }\end{array}$ & Level & LW & HW & OR & $95 \% \mathrm{Cl}$ & $\mathbf{P}$ \\
\hline \multirow{3}{*}{$\begin{array}{l}\text { Cow-to-stall ratio } \\
(\%)\end{array}$} & $>105$ & 10 & 4 & 0.343 & $0.070 ; 1.684$ & 0.131 \\
\hline & $95-105$ & 5 & 10 & 1.714 & $0.371 ; 7.918$ & \\
\hline & $<95$ & 6 & 7 & 1 & - & \\
\hline \multirow[t]{2}{*}{ Grooves in the floor } & No & 10 & 10 & 1.222 & $0.353 ; 4.235$ & 0.752 \\
\hline & Yes & 9 & 11 & 1 & - & \\
\hline \multirow{3}{*}{$\begin{array}{l}\text { Frequency floor scraping } \\
\text { (times/day) }\end{array}$} & $<2$ & 9 & 6 & 0.444 & $0.087 ; 2.276$ & 0.525 \\
\hline & $2-10$ & 5 & 7 & 0.933 & $0.169 ; 5.151$ & \\
\hline & $>10$ & 4 & 6 & 1 & - & \\
\hline \multirow[t]{2}{*}{ Floor scraping type } & MAN & 4 & 6 & 1.385 & $0.312 ; 6.136$ & 0.668 \\
\hline & AUT & 12 & 13 & 1 & - & \\
\hline \multirow{3}{*}{$\begin{array}{l}\text { Frequency claw trimming } \\
\text { (times/year) }\end{array}$} & $<2.0$ & 13 & 7 & 0.179 & $0.028 ; 1.136$ & 0.167 \\
\hline & $2-2.5$ & 6 & 7 & 0.389 & $0.056 ; 2.697$ & \\
\hline & $>2.5$ & 2 & 6 & 1 & - & \\
\hline \multirow[t]{2}{*}{ Type of claw trimming } & HER & 2 & 4 & 2.235 & $0.362 ; 13.782$ & 0.386 \\
\hline & IND & 19 & 17 & 1 & - & \\
\hline \multirow[t]{2}{*}{ Person who trims claws } & PRO & 1 & 2 & 2.105 & $0.176 ; 25.166$ & 0.557 \\
\hline & FAR & 20 & 19 & 1 & - & \\
\hline \multirow[t]{2}{*}{ Footbath routinely used } & No & 11 & 1 & 0.041 & $0.005 ; 0.367$ & 0.004 \\
\hline & Yes & 9 & 20 & 1 & - & \\
\hline \multirow[t]{2}{*}{ Flooring type } & SLA & 16 & 9 & 0.234 & $0.062 ; 0.882$ & 0.032 \\
\hline & SOL & 5 & 12 & 1 & - & \\
\hline \multirow[t]{2}{*}{ Rubber on the floors } & No & 20 & 13 & 0.081 & $0.009 ; 0.728$ & 0.025 \\
\hline & Yes & 1 & 8 & 1 & - & \\
\hline \multirow[t]{2}{*}{ Access to pasture } & No & 16 & 18 & 1.875 & $0.385 ; 9.120$ & 0.436 \\
\hline & Yes & 5 & 3 & 1 & - & \\
\hline \multicolumn{7}{|l|}{ Final model: $r^{2}=0.10$} \\
\hline \multirow{2}{*}{ Footbath routinely used } & No & 11 & 1 & 0.043 & $0.005 ; 0.387$ & 0.005 \\
\hline & Yes & 9 & 20 & 1 & - & \\
\hline
\end{tabular}

${ }^{1}$ Number of herds included in logistic regression models were partly lower than $n=21$, because single housing and management factors were not available for some herds. MAN = manual, AUT = automatic, HER = whole herd, IND = individual cows, PRO = professional, FAR = farmer, SLA = slatted floor; SOL = solid. 
Table 5.18: Potential influencing factors in univariable logistic regression analysis associated with being a herd with high welfare level $(\mathrm{HW})$ within the indicator "mastitis incidence" [Odds ratio, Confidence interval, bold $p$-values $(p<0.20)$ were included in multivariable analyses; final model presented at the bottom of the table]. ${ }^{1}$

\begin{tabular}{|c|c|c|c|c|c|c|}
\hline $\begin{array}{l}\text { Potential influencing } \\
\text { factors }\end{array}$ & Level & LW & HW & OR & $95 \% \mathrm{Cl}$ & $\mathbf{P}$ \\
\hline \multirow[t]{2}{*}{ Type of milking } & AMS & 5 & 1 & 0.160 & $0.017 ; 1.511$ & 0.110 \\
\hline & MP & 16 & 20 & 1 & - & \\
\hline \multirow{3}{*}{$\begin{array}{l}\text { Age of milking equipment } \\
\text { (years) }\end{array}$} & $>20$ & 3 & 6 & 2.000 & $0.378 ; 10.577$ & 0.360 \\
\hline & $10-20$ & 9 & 5 & 0.556 & $0.133 ; 2.325$ & \\
\hline & $<10$ & 9 & 9 & 1 & - & \\
\hline \multirow[t]{2}{*}{ Interim disinfection } & No & 7 & 8 & 1.230 & $0.347 ; 4.357$ & 0.748 \\
\hline & Yes & 14 & 13 & 1 & - & \\
\hline \multirow{2}{*}{$\begin{array}{l}\text { Milking frequency } \\
\text { (times/day) }\end{array}$} & $>2$ & 12 & 5 & 0.234 & $0.062 ; 0.882$ & 0.032 \\
\hline & 2 & 9 & 16 & 1 & - & \\
\hline \multirow{2}{*}{$\begin{array}{l}\text { Cleaning teats } \\
\text { (towels) }\end{array}$} & REU & 6 & 5 & 0.556 & $0.133 ; 2.325$ & 0.421 \\
\hline & DIS & 10 & 15 & 1 & - & \\
\hline \multirow[t]{2}{*}{ Pre-Dip routinely } & No & 17 & 16 & 0.376 & $0.064 ; 2.224$ & 0.281 \\
\hline & Yes & 2 & 5 & 1 & - & \\
\hline \multirow[t]{2}{*}{ Post-Dip routinely } & No & 7 & 5 & 0.536 & $0.136 ; 2.109$ & 0.372 \\
\hline & Yes & 12 & 16 & 1 & - & \\
\hline \multirow[t]{2}{*}{ Milking sick cows separate } & No & 12 & 12 & 0.750 & $0.199 ; 2.827$ & 0.671 \\
\hline & Yes & 6 & 8 & 1 & - & \\
\hline \multirow[t]{2}{*}{ Fixation after milking } & No & 11 & 15 & 1.591 & $0.417 ; 6.073$ & 0.497 \\
\hline & Yes & 7 & 6 & 1 & - & \\
\hline \multirow[t]{2}{*}{ Dry cow therapy } & DEM & 4 & 10 & 3.636 & $0.905 ; 14.609$ & 0.069 \\
\hline & ROU & 16 & 11 & 1 & - & \\
\hline \multirow[t]{2}{*}{ Intramammary seal } & No & 2 & 3 & 1.500 & $0.223 ; 10.076$ & 0.677 \\
\hline & Yes & 18 & 18 & 1 & - & \\
\hline \multirow[t]{3}{*}{ Udder control dry cows } & No & 7 & 3 & 0.297 & $0.060 ; 1.466$ & 0.329 \\
\hline & DEM & 5 & 5 & 0.692 & $0.154 ; 3.112$ & \\
\hline & Yes & 9 & 13 & 1 & - & \\
\hline \multicolumn{7}{|l|}{ Final model: $r^{2}=0.13$} \\
\hline \multirow{2}{*}{$\begin{array}{l}\text { Frequency milking } \\
\text { (times/day) }\end{array}$} & $>2$ & 12 & 5 & 0.208 & $0.054 ; 0.800$ & 0.022 \\
\hline & 2 & 9 & 16 & 1 & - & \\
\hline
\end{tabular}

${ }^{1}$ Number of herds included in logistic regression models were partly lower than $n=21$, because single housing and management factors were not available for some herds. AMS = automatic milking system, MP = milking parlour; REU = reusable, DIS = disposable; $\mathrm{DEM}=$ on demand, $\mathrm{ROU}=$ routinely. 
Table 5.19: Potential influencing factors in univariable logistic regression analysis associated with being a herd with high welfare level (HW) within the criterion "social behavior" [Odds ratio, Confidence interval, bold $p$-values $(p<0.20)$ were included in multivariable analyses; final model presented at the bottom of the table]. ${ }^{1}$

\begin{tabular}{|c|c|c|c|c|c|c|}
\hline $\begin{array}{l}\text { Potential influencing } \\
\text { factors }\end{array}$ & Level & LW & HW & OR & $95 \% \mathrm{Cl}$ & $\mathbf{P}$ \\
\hline \multirow[t]{2}{*}{ Regrouping in lactation } & Yes & 13 & 15 & 1.846 & $0.483 ; 7.062$ & 0.370 \\
\hline & No & 8 & 5 & 1 & - & \\
\hline \multirow{2}{*}{$\begin{array}{l}\text { Integration of heifers } \\
\text { (time) }\end{array}$} & PP & 17 & 12 & 0.314 & $0.078 ; 1.260$ & 0.102 \\
\hline & $\mathrm{AP}$ & 4 & 9 & 1 & - & \\
\hline \multirow{3}{*}{$\begin{array}{l}\text { Cow-to-stall ratio } \\
(\%)\end{array}$} & $>105$ & 11 & 3 & 0.099 & $0.018 ; 0.551$ & 0.030 \\
\hline & $95-105$ & 6 & 7 & 0.424 & $0.087 ; 2.061$ & \\
\hline & $<95$ & 4 & 11 & 1 & - & \\
\hline \multirow{3}{*}{$\begin{array}{l}\text { Mean feeding alley width } \\
\text { (m) }\end{array}$} & $<3.2$ & 10 & 3 & 0.167 & $0.031 ; 0.904$ & 0.082 \\
\hline & 3.2-3.6 & 6 & 9 & 0.833 & $0.185 ; 3.750$ & \\
\hline & $>3.6$ & 5 & 9 & 1 & - & \\
\hline \multirow{3}{*}{$\begin{array}{l}\text { Mean walking alley width } \\
\text { (m) }\end{array}$} & $<2.4$ & 8 & 3 & 0.292 & $0.056 ; 1.525$ & 0.231 \\
\hline & $2.4-2.7$ & 6 & 9 & 1.167 & $0.279 ; 4.871$ & \\
\hline & $>2.7$ & 7 & 9 & 1 & - & \\
\hline \multirow{3}{*}{$\begin{array}{l}\text { Mean crossover width } \\
\text { (m) }\end{array}$} & $<2.4$ & 7 & 5 & 0.446 & $0.090 ; 2.215$ & 0.612 \\
\hline & $2.4-3.0$ & 7 & 8 & 0.714 & $0.158 ; 3.231$ & \\
\hline & $>3.0$ & 5 & 8 & 1 & - & \\
\hline \multirow{3}{*}{$\begin{array}{l}\text { Mean walking space } \\
\left(\mathrm{m}^{2}\right)\end{array}$} & $<3.7$ & 10 & 5 & 0.222 & $0.045 ; 1.094$ & 0.181 \\
\hline & $3.7-4.4$ & 7 & 7 & 0.444 & $0.092 ; 2.150$ & \\
\hline & $>4.4$ & 4 & 9 & 1 & - & \\
\hline \multirow[t]{2}{*}{ Concentrate feeder station } & No & 11 & 17 & 3.864 & $0.967 ; 15.443$ & 0.056 \\
\hline & Yes & 10 & 4 & 1 & - & \\
\hline \multirow[t]{2}{*}{ Rotating cow brush } & No & 8 & 9 & 1.219 & $0.355 ; 4.185$ & 0.754 \\
\hline & Yes & 13 & 12 & 1 & - & \\
\hline \multirow[t]{2}{*}{ Feeding rack type } & NR & 11 & 14 & 1.818 & $0.522 ; 6.331$ & 0.348 \\
\hline & $\mathrm{HL}$ & 10 & 7 & 1 & - & \\
\hline \multirow{3}{*}{$\begin{array}{l}\text { Cow-to-feeding place ratio } \\
(\%)\end{array}$} & $>118$ & 7 & 5 & 1.786 & $0.349 ; 9.127$ & 0.042 \\
\hline & $105-118$ & 4 & 12 & 7.500 & $1.484 ; 37.905$ & \\
\hline & $<105$ & 10 & 4 & 1 & - & \\
\hline \multirow{3}{*}{$\begin{array}{l}\text { Trough length per cow } \\
(\mathrm{cm})\end{array}$} & $<4.7$ & 11 & 4 & 0.218 & $0.047 ; 1.005$ & 0.092 \\
\hline & $4.7-6.8$ & 4 & 7 & 1.050 & $0.214 ; 5.158$ & \\
\hline & $>6.8$ & 6 & 10 & 1 & - & \\
\hline \multicolumn{7}{|l|}{ Final model: $r^{2}=0.18$} \\
\hline & $>105$ & 11 & 3 & 0.099 & $0.018 ; 0.551$ & 0.030 \\
\hline \multirow[t]{2}{*}{ Cow-to-stall ratio (\%) } & $95-105$ & 6 & 7 & 0.424 & $0.087 ; 2.061$ & \\
\hline & $<95$ & 4 & 11 & 1 & - & \\
\hline
\end{tabular}

${ }^{1}$ Number of herds included in logistic regression models were partly lower than $n=21$, because single housing and management factors were not available for some herds. $\mathrm{PP}=$ after calving, $\mathrm{AP}=$ before calving; excluding lying areas; $\mathrm{NR}=$ neck rail; $\mathrm{HL}=$ head lock. 


\subsection{Discussion}

The objective of the present study was to compare housing and management factors of dairy farms with lowest (LW) and highest (HW) animal welfare levels regarding several important animal welfare indicators in a benchmarking approach. Therefore, 63 loose housing dairy cattle farms with zero-pasturing were assessed using multiple animal-based measures of the Welfare Quality ${ }^{\circledR}$ Assessment protocol (Welfare Quality, 2012). Mean herd size of the sample (368 cows) was on a higher level compared to average herd size (61 cows) in Germany (Destatis, 2017). Nevertheless, under consideration of the herd size development in recent years it is likely that the intensification of milk production continues with further rising herd sizes and results of the present study are therefore of increasing importance for dairy farms in Germany. Several farm types (e.g., tiestalls, straw-bedded barns, and farms with pasture access) were excluded in the present study, in order to ensure the comparability between dairy farms. Distribution of specific housing conditions (e.g., cubicle types, flooring types and stall climate) was not considered during farm acquisition. No statistical data concerning their proportions in Germany were available, thus it was not possible to compile a representative sample. However, housing conditions were typical for zero-grazing free stall dairy farms and results are therefore relevant for a major part of the German dairy cattle population. Prevalences of most examined animal welfare indicators (except severe lameness) and scores of welfare criterion were in accordance to the findings of other studies using the WQP. For example, Popescu et al. (2014) observed on average $13.1 \%$ lean cows in loose houses, whereas Zuliani et al. (2017) proved $18.3 \%$ cows with a lower body condition score in Italian mountain farms. Lower median percentages of lean cows $(9.1 \%)$ were found in a French study by De Boyer des Roches (2014), whereby visited farms showed a wide range ( 0.0 to 87.5$)$. Higher prevalances (33.0\%) were determined by Benatellah et al. (2017) in Algerian dairy farms. The observed percentages of cows with severe integument alterations (lesions/swellings) in the present study comply with the mean prevalence of $39.2 \%$ in French (Coignard et al., 2013), 37.6\% in Dutch (de Vries et al., 2013) and $29.8 \%$ in British (Heath et al., 2014) dairy cattle farms. Lower percentages of lesions and swellings were found in Italy (12.0\%) 
with a wide range ( 0.5 to 26.2 ) between the farms (Zuliani et al., 2017). The prevalences of severe lame cows in the present study are on a higher level compared to other examinations using the WQP. Coignard et al. (2013) found in France only $2.9 \%$ ( 0.0 to 34.6) severe lame cows, whereas de Vries et al. (2013) detected 5.0 $\%$ (0.0 to 65.9) in the Netherlands. A British study revealed a similar result of $4.9 \%$ (0 to $47.6 \%$ ) severe lame cows (Heath et al., 2014). Conceivably, lameness prevalence in the present study was influenced by a detrimental combination of several risk factors within the study design (Dippel et al., 2009). Straw barns, tie stalls and pasture systems were excluded from the study, which are known as beneficial for preventing claw disorders or lameness (Haskell et al., 2006; Espejo and Endres, 2007; Cook et al., 2016). Percentages of cows with high milk somatic cell counts were in accordance to other studies. Coignard et al. (2013) observed on average $20.6 \%$ dairy cows with a SCC above 400,000 cells ( 2.0 to $46.6 \%$ ). The mastitis incidence rates were somewhat lower (11.1\%) in the Netherlands (de Vries et al., 2013) and (15.5\%) in the United Kingdom (Heath et al., 2014). The number of head butts and displacements per cow and hour were at a comparable level to previous findings. For example, Andreasen et al. (2013) reported that all farms achieved high scores in this criterion due to the low occurrence of agonistic interactions between the cows. In a Belgian study de Graaf et al. (2017) calculated on average a score of 77.0 (55.2 to 91.2) at the beginning and 76.0 (56.8 to 98.4 ) at the end of the indoor season.

\section{Very lean cows}

Farms with higher feeding frequencies, i.e. providing fresh feed more than one time per day were potentially at a lower risk of having poor body condition scores $(p<0.20)$. These findings are in accordance with DeVries et al. (2005), who observed a positive effect of higher ( 2 times/day) compared to lower ( 1 time/day) feeding frequencies on the feeding behavior of dairy cattle. The authors reported, that dairy cows increased their daily feeding time and subordinate cows were less frequently displaced at the feed rack (DeVries et al., 2005). Additionally, higher feeding frequencies could reduce the amount of sorting for grain concentrate components (Sova et al., 2013). This behavior can lead to a dilution of the ration and consequently in an insufficient uptake of nutrients, particularly for subordinate cows which are often forced to consume feed remains (Hosseinkhani et al., 
2008; Endres and Espejo, 2010). Dairy farms of the high welfare group (HW) had frequently more than one feeding group (i.e., providing at least two different rations), compared to dairy farms of the low welfare group (LW). Establishment of different feeding groups allows the farmers to adjust the rations for specific feeding requirements in particular lactation stages (Bewley et al., 2008; Adams et al., 2017). Provision of high amounts of concentrate feeds ( $>8.5 \mathrm{~kg} /$ day) not surprisingly reduces the risk for higher percentages of lean cows. Similarly, Berry et al. (2006) found heavier cows with smaller weight losses during lactation in groups with high energy feed levels. Nevertheless, higher amounts of concentrate feeds might contribute to overconditioning of the dairy cows in the late lactation stages. Fat cows more often develop metabolic disorders such as ketosis (Roche et al., 2009) and dairy farmers therefore should feed the cows according to the energy requirements of the specific lactation stages. However, none of the associated housing and management variables of the univariable analysis was significant in the multivariable logistic regression.

\section{Lesions/Swellings}

None of preselected housing and management variables affects the probability for cows with less lesions or swellings ( $p>0.20)$. These findings were unexpected, because the prevalence of severe integument alterations is mainly influenced by housing and management conditions (Nash et al., 2016; Adams et al., 2017). Cubicles with rubber mats seemed to be a risk factor for hock lesions, because the cows lie on a hard and abrasive surface (Haskell et al., 2006; Brenninkmeyer et al., 2013). Wechsler et al. (2000) determined higher incidences of hairless patches, scabs or wounds in cubicles with soft lying mats, compared to cubicles with straw bedding $(p<0.05)$. Furthermore, impacts of cubicle size on the prevalences of integument alterations were reported in several studies (Kester et al., 2014). For example, Potterton et al. (2011) detected less hock swellings, if the distance between curb and brisket board exceeded $178 \mathrm{~cm}$. Kielland et al. (2009) determined a lower risk for hock injuries, if the diagonal free stall length (i.e., distance from neck rail to rear curb) was larger than $196 \mathrm{~cm}$, compared to shorter distances $(\leq 196 \mathrm{~cm})$. Less swellings (OR 0.64) were observed, if cows were not in contact with furniture while rising in a British study (Potterton et al., 2011). Besides the impact of the lying area on integument alterations, other barn equipment 
might also influence the amount of cows with lesions or swellings (e.g., feeding rack type, feeding rack height). Zaffino Heyerhoff et al. (2014) observed higher risks of developing neck injuries in farms with lower $(\leq 149 \mathrm{~cm})$, compared to farms with higher feed rail heights $(>149 \mathrm{~cm})$. However, contrary to the expectations none of the preselected housing and management variables were associated in the univariable logistic regression. Conceivably, management factors (e.g., frequency of litter or bedding material) were more important for the amount of integument alterations than housing environment alone (Kester et al., 2014). These factors are warranted to be considered in future research.

\section{Severe Lameness}

Dairy farms with higher cow-to-stall ratios (>105\%) had a higher risk of severely lame cows, compared to dairy farms with lower cow-to-stall ratios. These findings might be explained by the changing cow behavior under overstocked conditions (Espejo and Endres, 2007; Winckler et al., 2015). For example, Falk et al. (2012) detected higher standing times in the alleys with increasing cow-to-stall ratios due to waiting times for vacant cubicles. Prolonged standing in the soiled walking alleys and crossovers negatively affect the claw health due to chemical exposures on sole and heel (Webster, 2001). Higher claw trimming frequencies ( $>2.5 \mathrm{x} /$ year) were associated with lower risks of severely lame cows, compared to infrequent claw trimming. These findings were similar to Espejo and Endres (2007), who stated a positive effect of higher hoof trimming frequencies on the lameness prevalence in high-producing dairy cattle $(p<0.05)$. Contrastingly, Chapinal et al. (2013) did not determine an association of hoof trimming frequency on lameness in dairy cattle. Farms with slatted floors had a higher risk of severely lame cows, compared to farms with solid floors. Similarly, Dippel et al. (2009) observed higher lameness prevalences in Austrian dairy cattle farms in slatted (OR 1.3), compared to solid (OR 1.0) floor. Rouha-Mülleder et al. (2009) also proved higher percentages of lame cows in farms with slatted floors. The authors stated, that lameness prevalences increases due to protruding ridges or differences in the contour lines (Dippel et al., 2009; Rouha-Mülleder et al., 2009). No association of flooring type on the amount of lame cows was determined by Solano et al. (2015). Results of the present study showed an effect of routinely usage of footbaths on 
the number of severely lame cows in the multivariable analysis $(p<0.05)$. Footbaths were routinely used by $95 \%$ of the farms within group HW, compared to only $43 \%$ in group LW. Similarly, an associated decrease of lameness prevalence with higher footbath frequencies was found by Chapinal et al. (2013). No association between footbaths usage and lameness prevalence was examined by Espejo and Endres (2007) and Adams et al. (2017). This might be explained by different causes of lameness. Footbaths are beneficial for preventing infectious diseases, but may not help to improve other claw disorders (Espejo and Endres, 2007; Chapinal et al., 2013).

\section{Mastitis Incidence}

Herd managers of group LW used antibiotic dry cow therapy more frequently, compared to those of group HW. The observed association was in accordance with the results of a case-control study in Sweden (Nyman et al., 2007). The authors stated, that dairy cows of herds with high proportions of clinical mastitis were treated more frequently, compared to dairy cows of herds with low proportions of clinical mastitis (Nyman et al., 2007). However, these results indicate no causal relationship between antibiotic dry cow therapy and higher percentages of cows with mastitis incidence. Farmers with higher clinical rates of mastitis are probably more inclined to dry off all cows with antibiotics in order to prevent further infections (Barkema et al., 1999). Contrastingly, Doherr et al. (2007) reported lower risks of subclinical mastitis with routine use of antibiotic dry cow therapy (OR 0.5), compared to infrequent antibiotic treatments (OR 1). Higher milking frequencies (>2 $x /$ day) were positively associated with higher milk somatic cell counts within the multivariable analysis $(p<0.05)$. These findings were unexpected, because increased milking frequency is usually associated with lower milk somatic cell count levels due to more frequent discharging of the udder (Hovinen and Pyörälä, 2011). Lower percentages of cows with high milk somatic cell counts were detected in herds with three, compared to herds with two milking times by Smith et al. (2002). This contradictory result might be influenced by the different milking technique types in the present study. Dairy farms with automatic milking systems (AMS) were associated with higher risks of cows showing signs of mastitis, compared to dairy farms with conventional milking parlors $(p<0.20)$. AMS are characterized by higher milking frequencies ( $>2 x /$ day) and deemed to 
be a risk factor for udder health (Hovinen and Pyörälä, 2011; Jacobs and Siegford, 2012). The authors stated, that udder cleaning processes are conducted in a standardized way without final control of udder cleanliness. Therefore, soiled teats might cause udder infections with environmental pathogens (Dohmen et al., 2010). Furthermore, milking units of the AMS are shared by up to 70 cows. This might lead to higher risks of transmitting pathogens in AMS, compared to conventional milking parlors with several milking units (Hovinen and Pyörälä, 2011; Barkema et al., 2015). However, it has to be mentioned, that the distribution of AMS and milking parlors in the present study was unequal (6 AMS vs. 36 MP). Therefore, the observed results had to be interpreted carefully.

\section{Social Behavior}

Dairy farms with medium (95-105\%) to high (>105\%) cow-to-stall ratios were at a higher risk of frequent agonistic interactions between dairy cows as shown in multivariable analysis $(p<0.05)$. These findings are in accordance with previous studies. For example, Fregonesi et al. (2007) determined a curvilinear increase of displacements $(0.7,0.9,1.6,2.1$, and $1.9 \mathrm{n} / 5 \mathrm{~h})$ with increasing cow-to-stall ratios $(100,109,120,133$, and 150\%). Similarly, Winckler et al. (2015) recorded five times higher numbers of displacements under overstocked (150\%), compared to understocked $(75 \%)$ housing conditions. Furthermore, higher amounts of agonistic interactions were found in dairy farms with low $(<105 \%)$, compared to medium (105-118\%) and high (>118\%) cow-to-feeding place ratios. The results of the present study are in conflict with the findings reported in the literature. For example, Huzzey et al. (2006) examined the influence of different feed bunk spaces $(0.81,0.61,0.41$, and $0.21 \mathrm{~m} / \mathrm{cow})$ on several behavioral patterns and investigated an association of less feed bunk space per cow with higher amounts of agonistic behaviors. Similarly, Krawczel et al. (2012) compared different feed bunk densities $(100,113,131$, and 142\%) regarding social behavior at the feed barrier and determined a continuous increase of displacements between treatments. This unexpected result might be explained by the fact that social interactions were not only assessed at the feed bunk, but also in other parts of the barn such as walking alleys or resting areas (Welfare Quality, 2012). Competition on limited resources such as cow brushes, water troughs or concentrate feeders, might have influenced the number of agonistic interactions. For example, Val- 
Laillet et al. (2008) determined most displacements at the mechanical brushes, compared to feed bunk and stalls (considering the function of time spent at the resource). Similarly, de Vries et al. (2015) found a positive relationship between the presence of cow brushes and higher numbers of displacements in dairy farms. Competitive behavior of dairy cows at a concentrate self-feeder were examined by Katainen et al. (2005). The authors reported that nearly half of the visits $(42 \%)$ at the concentrate feeder was interrupted by butting of other cows. Positive associations between provision of concentrate feeder stations and less trough length per cow $(<4.7 \mathrm{~cm})$ with higher numbers of agonistic interactions were also found in the present study $(p<0.20)$. Contrastingly, no association between provision of rotating cow brushes and the results within the criterion "social behavior" was proven $(p>0.20)$.

\subsection{Conclusions}

Findings of the present study indicate several associations between housing and management factors and single animal welfare indicators of the Welfare Quality ${ }^{\circledR}$ protocol for dairy cattle in univariable statistical analysis. Contrastingly, only single effects on severe lameness, mastitis incidence and social behavior were determined in multivariable statistical analysis. Lacking of more frequent statistically validated associations might be explained by the relatively small sample size of the present study and partly missing values within the management dataset, which further reduces the sample size within multivariable analysis. Under consideration of these limitations of the present study, the applied benchmarking approach delivered promising results. Comparing farms with higher and lower animal welfare performances within specific animal welfare indicators regarding selected housing and management factors, provide useful information about effective options to improve animal welfare in dairy cattle. However, further research with larger datasets considering different farm types (conventional, organic), housing systems (tiestall, free stall, straw yards) and management options (pasture access, indoor housing) should be conducted to increase explanatory power of this benchmarking approach. 


\subsection{Acknowledgments}

This study was funded by the German Federal Ministry of Education and Research within the project "Sustainable Land Management in North German Lowland" (NaLaMa-nt) and financially supported by the H. Wilhelm Schaumann Foundation. The authors thank the different stakeholders for their support during farm acquisition and the participating farmers for their time and effort.

\subsection{References}

Adams, A.E., J.E. Lombard, C.P. Fossler, I.N. Román-Muñiz, and C.A. Kopral. 2017. Associations between housing and management practices and the prevalence of lameness, hock lesions, and thin cows on US dairy operations. J. Dairy Sci. 100:2119-2136. https://doi.org/10.3168/jds.2016115 17.

Andreasen, S.N., F. Wemelsfelder, P. Sandoe, and B. Forkman. 2013. The correlation of qualitative behavior assessments with Welfare Quality ${ }^{\circledR}$ protocol outcomes in on-farm welfare assessment of dairy cattle. Appl. Anim. Beh. Sci. 143:9-17. https://doi.org/10.1016/j.applanim.2012.11.013.

Arnott, G., C.P. Ferris, and N.E. O'Connell. 2016. Review: welfare of dairy cows in continuously housed and pasture-based production systems. Animal. $11: 261-273$. https://doi.org/10.1017/S1751731116001336.

Barkema, H.W., M.A.G. von Keyserlingk, J.P. Kastelic, T.J.G.M. Lam, C. Luby, J.-P. Roy, S.J. LeBlanc, G.P. Keefe, and D.F. Kelton. 2015. Invited review: Changes in the dairy industry affecting dairy cattle health and welfare. J. Dairy Sci. 98:7426-7445. https://doi.org/10.3168/jds.2015-9377.

Barkema, H.W., Y.H. Schukken, T.J.G.M. Lam, M.L. Beiboer, G. Benedictus, and A. Brand. 1999. Management practices associated with the incidence rate on clinical mastitis. J. Dairy Sci. 82:1643-1654. https://doi.org/10.3168/jds. S0022-0302(99)75393-2.

Barrientos, A.K., N. Chapinal, D.M. Weary, E. Galo, and M.A.G. von Keyserlingk. 2013. Herd-level risk factors for hock injuries in freestall-housed dairy cows in the northeastern United States and California. J. Dairy Sci. 96:3758-3765. https://doi.org/10.3168/jds.2012-6389.

Benatallah, A., F. Ghozlane, and M. Marie. 2015. Dairy cow welfare assessment on Algerian farms. Afr. J. Agric. Res. 10:895-901. https://doi.org/10.5897/ AJAR2015.9483. 
Berry, D.P., R.F. Veerkamp, and P. Dillon. 2006. Phenotypic profiles for body weight, body condition score, energy intake, and energy balance across different parities and concentrate feeding levels. Livest. Sci. 104:1-12. https://doi.org/10.1016/j.livsci.2006.02.012.

Bewley, J.M., and M.M. Schutz. 2008. Review: an interdisciplinary review of body condition scoring for dairy cattle. Prof. Anim. Sci. 24:507-529. https:// doi.org/10.15232/S1080-7446(15)30901-3.

Brenninkmeyer, C., S. Dippel, J. Brinkmann, S. March, C. Winckler, and U. Knierim, 2013. Hock lesion epidemiology in cubicle housed dairy cows across two breeds, farming systems and countries. Prev. Vet. Med. 109:236-245. https://doi.org/10.1016/i.prevetmed.2012.10.014.

Chapinal, N., A.K. Barrientos, M.A.G. von Keyserlingk, E. Galo, and D.M. Weary. 2013. Herd-level risk factors for lameness in freestall farms in the northeastern United States and California. J. Dairy Sci. 96:318-328. https://doi. org/10.3168/jds.2012-5940.

Coignard, M., R. Guatteo, I. Veissier, A. de Boyer des Roches, L. Mounier, A. Lehébel, and N. Bareille. 2013. Description and factors of variation of the overall health score in French dairy cattle herds using the Welfare Quality ${ }^{\circledR}$ Assessment protocol. Prev. Vet. Med. 112:296-308. https://doi.org/10.10 16/i.prevetmed.2013.07.018.

Collings, L.K.M., D.M. Weary, N. Chapinal, and M.A.G. von Keyserlingk. 2011. Temporal feed restriction and overstocking increase competition for feed by dairy cattle. J. Dairy Sci. 94: 5480-5486. https://doi.org/10.3168/jds. 2011-4370.

Cook, N.B., J.P. Hess, M.R. Foy, T.B. Bennett, and R.L. Brotzman. 2016. Management characteristics, lameness, and body injuries of dairy cattle housed in high-performance dairy herds in Wisconsin. J. Dairy Sci. 99:5879-5891. https://doi.org/10.3168/jds.2016-10956.

Cook, N.B., T.B. Bennett, and K.V. Nordlund. 2004. Effect of free stall surface on daily activity patterns in dairy cows with relevance to lameness prevalence. J. Dairy Sci. 87:2912-2922. https://doi.org/10.3168/jds.S0022-0302(04) 73422-0.

De Boyer des Roches, A., I. Veissier, M. Coignard, N. Bareille, R. Guatteo, J. Capdeville, E. Gilot-Fromont, and L. Monier. 2014. The major welfare problems of dairy cows in French commercial farms: an epidemiological approach. Anim. Welf. 23: 467-478. https://doi.org/10.7120/09627286.23. $\underline{4.467 .}$ 
De Graaf, S., B. Ampe, and F.A.M. Tuyttens. 2017. Assessing dairy cow welfare at the beginning and end of the indoor period using the Welfare Quality ${ }^{\circledR}$ protocol. Anim. Welf. 26: 213-221. https://doi.org/10.7120/09627286. 26.2. $\underline{213 .}$.

De Vries, M., E.A.M. Bokkers, C.G. van Reenen, B. Engel, G. van Schaik, T. Dijkstra, and I.J.M. de Boer. 2015. Housing and management factors associated with indicators of dairy cattle welfare. Prev. Vet. Med. 118:80-92. https://doi.org/10.1016/j.prevetmed. 2014.11.016.

De Vries, M., E.A.M. Bokkers, G. van Schaik, B. Engel, T. Dijkstra, and I.J.M. de Boer. 2016. Improving the time efficiency of identifying dairy herds with poorer welfare in a population. J. Dairy Sci. 99:8282-8296. http://dx.doi. org/10.3168/jds.2015-9979.

De Vries, M., E.A.M. Bokkers, G. van Schaik, R. Botreau, B. Engel, T. Dijkstra, and I.J.M. de Boer. 2013. Evaluating results of the Welfare Quality multicriteria evaluation model for classification of dairy cattle welfare at the herd level. J. Dairy Sci. 96:6264-6273. http://dx.doi.org/10.3168/jds.2012-6129.

Destatis. 2017. Land- und Forstwirtschaft, Fischerei Rinder- und Schweinebestand. Statistisches Bundesamt. Fachserie 3 Reihe 4.1. www.destatis.de/DE/Publikationen/Thematisch/LandForstwirtschaft/ViehbestandTierischeErzeugung/Viehhaltung2030213169004.pdf?blob=publicationFile (Accessed 07. October 2017).

DeVries, T.J., M.A.G. von Keyserlingk, and K.A. Beauchemin. 2005. Frequency of feed delivery affects the behavior of lactating dairy cows. J. Dairy. Sci. 88:3553-3562. https://doi.org/10.3168/jds.S0022-0302(05)73040-X.

Dippel, S., M. Dolezal, C. Brenninkmeyer, J. Brinkmann, S. March, U. Knierim, and C. Winckler. 2009. Risk factors for lameness in cubicle housed Austrian Simmental dairy cows. Prev. Vet. Med. 90:102-112. http://dx.doi.org/ 10.1016/i.prevetmed.2009.03.014.

Doherr, M.G., M. Roesch, W. Schaeren, M. Schallibaum, and J.W. Blum. 2007. Risk factors associated with subclinical mastitis in dairy cows on Swiss organic and conventional production system farms. Vet. Med. 52:487-495. https://doi.org/10.17221/2060-VETMED.

Dohmen, W., F. Neijenhuis, and H. Hogeveen. 2010. Relationship between udder health and hygiene on farms with an automatic milking system. J. Dairy Sci. 93:4019-4033. https://doi.org/10.3168/jds.2009-3028.

EFSA. 2010. Animal welfare risk assessment guidelines on housing and management. Technical report (EFSA-Q-2009-00844). Wageningen UR Livestock Research. http://www.efsa.europa.eu/en/supporting/pub/en-87. (Accessed 04. November 2017). 
Endres, M.I., and L.A. Espejo. 2010. Feeding management and characteristics of rations for high-producing dairy cows in freestall herds. J. Dairy Sci. 93:822-829. https://doi.org/10.3168/jds.2008-2007.

Espejo, L.A. and M.I. Endres. 2007. Herd-level risk factors for lameness in highproducing Holstein cows housed in freestall barns. J. Dairy Sci. 90, 306314. https://doi.org/10.3168/jds.S0022-0302(07)72631-0.

Falk, A.C., D.M. Weary, C. Winckler, and M.A.G. von Keyserlingk. 2012. Preference for pasture versus freestall housing by dairy cattle when stall availability indoors is reduced. J. Dairy Sci. 95, 6409-6415. https://doi.org/10. 3168/jds.2011-5208.

Fregonesi, J.A., C.B. Tucker, and D.M. Weary. 2007. Overstocking reduces lying time in dairy cows. J. Dairy Sci. 90, 3349-3354. https://doi.org/10.3168/ ids.2006-794.

Haskell, M.J., L.J. Rennie, V.A. Bowell, M.J. Bell, and A.B. Lawrence. 2006. Housing system, milk production, and zero-grazing effects on lameness and leg injury in dairy cows. J. Dairy Sci. 89:4259-4266. https://doi.org/ 10.3168/jds.S0022-0302(06)72472-9.

Heath, C.A.E., Y. Lin, S. Mullan, W.J. Browne, and D.C.J. Main. 2014. Implementing Welfare Quality ${ }^{\circledR}$ in UK assurance schemes: evaluating the challenges. Anim. Welf. 23, 95-107. https://doi.org/10.7120/09627286.23.1. 095.

Hosseinkhani, A., T.J. DeVries, K.L. Proudfoot, R. Valizadeh, D.M. Veira, and M.A.G. von Keyserlingk. 2008. The effects of feed bunk competition on the feed sorting behavior of close-up dry cows. J. Dairy Sci. 91:1115-1121. https://doi.org/10.3168/jds.2007-0679.

Hovinen, M., and S. Pyörälä. 2011. Invited review: Udder health of dairy cows in automatic milking. J. Dairy Sci. 94:547-562. https://doi.org/10.3168/jds.20 10-3556.

Huzzey, J.M., T.J. DeVries, P. Valois, and M.A.G. von Keyserlingk. 2006. Stocking density and feed barrier design affect the feeding and social behavior of dairy cattle. J. Dairy Sci. 89, 126-133. https://doi.org/10.3168/jds.S00220302(06)72075-6.

Jacobs, J.A., and J.M. Siegford. Invited review: The impact of automatic milking systems on dairy cow management, behavior, health, and welfare. J. Dairy sci. 95:2227-2247. https://doi.org/10.3168/jds.2011-4943.

Katainen, A., M. Norring, E. Manninen, J. Laine, T. Orava, K. Kuoppala, and H. Saloniemi. 2005. Competitive behavior of dairy cows at a concentrate self- 
feeder. Acta Agric. Scand. A Anim. Sci. 55:98-105. https://doi.org/10.1080 109064700500239453.

Kester, E., M. Holzhauer, and K. Frankena. 2014. A descriptive review of the prevalence and risk factors of hock lesions in dairy cows. Vet. J. 202: 222228. https://doi.org/10.1016/.j.tvil.2014.07.004.

Kielland, C., L.E. Ruud, A.J. Zanella, and O. Osteras. 2009. Prevalence and risk factors for skin lesions on legs of dairy cattle housed in freestalls in Norway. J. Dairy Sci. 92:5487-5496. https://doi.org/10.3168/jds.2009-2293.

Krawczel, P.D., L.B. Klaiber, R.E. Butzler, L.M. Klaiber, H.M. Dann, C.S. Mooney and R.J. Grant. 2012. Short-term increases in stocking density affect the lying and social behavior, but not the productivity, of lactating Holstein dairy cows. J. Dairy Sci. 95, 4298-4308. https://doi.org/10.3168/jds.20114687.

Lombard, J.E., C.B. Tucker, M.A.G. von Keyserlingk, C.A. Kopral and D.M. Weary. 2010. Associations between cow hygiene, hock injuries, and free stall usage on US dairy farms. J. Dairy Sci. 93, 4668-4676. https://doi.org/ 10.3168/jds.2010-3225.

Nash, C.G.R., D.F. Kelton, T.J. DeVries, E. Vasseur, J. Coe, J.C. Zaffino Heyerhoff, V. Bouffard, D. Pellerin, J. Rushen, A.M. de Passillé, and D.B. Haley. 2016. Prevalence of and risk factors for hock and knee injuries on dairy cows in tiestall housing in Canada. J. Dairy Sci. 99:6494-6506. https:// doi.org/10.3168/jds.2015-10676.

Nyman, A.-K., T. Ekman, U. Emanuelson, A.H. Gustafsson, K. Holtenius, K. Persson Waller, and C. Hallén Sandgren. 2007. Risk factors associated with the incidence of veterinary-treated clinical mastitis in Swedish dairy herds with a high milk yield and a low prevalence of subclinical mastitis. Prev. Vet. Med. 78:142-160. https://doi.org/10.1016/j.prevetmed.2006. 10.002.

Popescu, S., C. Borda, E.A. Diugan, M. Niculae, R. Stefan, and C.D. Sandru. 2014. The effect of the housing system on the welfare quality of dairy cows. Ital. J. Anim. Sci. 13:2940. https://doi.org/10.4081/ijas.2014.2940.

Potterton, S.L., M.J. Green, J. Harris, K.M. Millar, H.R. Whay, and J.N. Huxley. 2011. Risk factors associated with hair loss, ulceration, and swelling at the hock in freestall-housed UK dairy herds. J. Dairy Sci. 94:2952-2963. https ://doi.org/10.3168/jds.2010-4084.

Roche, J.R., N.C. Friggens, J.K. Kay, M.W. Fisher, K.J. Stafford, and D.P. Berry. 2009. Invited review: Body condition score and its association with dairy cow productivity, health, and welfare. J. Dairy Sci. 92:5769-5801. https:// doi.org /10.3168/jds.2009-2431. 
Rodrigues, A.C.O., D.Z. Caraviello, and P.L. Ruegg. 2005. Management of Wisconsin dairy herds enrolled in milk quality teams. J. Dairy Sci. 88:26602671. https://doi.org/10.3168/jds.S0022-0302(05)72943-X.

Rouha-Mülleder, C., C. Iben, E. Wagner, G. Laaha, J. Troxler, and S. Waiblinger. 2009. Relative importance of factors influencing the prevalence of lameness in Austrian cubicle loose-housed dairy cows. Prev. Vet. Med. 92:123133. https://doi.org/10.1016/j.prevetmed.2009.07.008.

Smith, J.W., L.O. Ely, W.M. Graves, and W.D. Gilson. 2002. Effect of milking frequency on DHI performance measures. J. Dairy Sci. 85:3526-3533. https://doi.org/10.3168/jds.S0022-0302(02)74442-1.

Solano, L., H. W. Barkema, E. A. Pajor, S. Mason, S. J. LeBlanc, J. C. Zaffino Heyerhoff, C. G. R. Nash, D. B. Haley, E. Vasseur, D. Pellerin, J. Rushen, A. M. de Passillé, and K. Orsel. 2015. Prevalence of lameness and associated risk factors in Canadian Holstein-Friesian cows housed in freestall barns. J. Dairy Sci. 98:6978-6991. https://doi.org/10. 3168/jds.2015-9652.

Sova, A.D., S.J. LeBlanc, B.W. McBride, and T.J. DeVries. 2013. Associations between herd-level feeding management practices, feed sorting, and milk production in freestall dairy farms. J. Dairy Sci. 96:4759-4770. https:// doi.org/10.3168/jds.2013-6679.

Val-Laillet, D., D.M. Veira, and M.A.G. von Keyserlingk. 2008. Short communication: Dominance in free-stall-housed dairy cattle is dependent upon resource. J. Dairy Sci. 91:3922-3926. https://doi.org/10.3168/jds.2008-1332.

Von Keyserlingk, M.A.G., A. Barrientos, K. Ito, E. Galo and D.M. Weary. 2012. Benchmarking cow comfort on North American freestall dairies: Lameness, leg injuries, lying time, facility design, and management for high-producing Holstein dairy cows. J. Dairy Sci. 95, 7399-7408. https://doi.org/ 10.3168/ jds.2012-5807.

Webster, A.J.F. 2001. Effects of housing and two forage diets on the development of claw horn lesions in dairy cows at first calving and in first lactation. Vet. J. 162, 56-65. https://doi.org/10.1053/tvjl.2001.0569.

Wechsler, B., J. Schaub, K. Friedli, and R. Hauser. 2000. Behaviour and leg injuries in dairy cows kept in cubicle systems with straw bedding or soft lying mats. Appl. Anim. Beh. Sci. 69:189-197. https://doi.org/10.1016/S01681591(00)00134-9.

Welfare Quality ${ }^{\circledR}$. 2012. Welfare Quality ${ }^{\circledR}$ Assessment protocol for cattle. Welfare Quality ${ }^{\circledR}$ Consortium, Lelystad, Netherlands. www.welfarequalitynetwork. net/network/45848/ 7/0/40 (Accessed 21. August 2017). 
Wenz, J.R., S.M. Jensen, J.E. Lombard, B.A. Wagner, and R.P. Dinsmore. 2007. Herd management practices and their association with bulk tank somatic cell count on United States dairy operations. J. Dairy Sci. 90:3652-3659. https://doi.org/10.3168/jds.2006-592.

Winckler, C., C.B. Tucker and D. Weary. 2015. Effects of under- and overstocking freestalls on dairy cattle behavior. Appl. Anim. Beh. Sci. 170, 14-19. https: //doi.org/10.1016/..applanim.2015.06.003.

Zaffino Heyerhoff, J.C., S.J. LeBlanc, T.J. DeVries, C.G.R. Nash, J. Gibbons, K. Orsel, H.W. Barkema, L. Solano, J. Rushen, A.M. de Passillé, and D.B. Haley. 2014. Prevalence of and factors associated with hock, knee, and neck injuries on dairy cows in freestall housing in Canada. J. Dairy Sci. 97:173-184. https://dx.doi.org/10.3168/jds.2012-6367.

Zuliani, A., A. Romanzin, M. Corazzin, S. Salvador, J.C. Abrahantes, and S. Bovolenta. 2017. Welfare assessment in traditional mountain dairy farms: above and beyond resource-based measures. Anim. Welf. 26: 203-211. https://doi.org/10.7120/09627286.26.2.203. 


\section{KAPITEL 6}

Allgemeine Diskussion 


\section{Kapitel $6 \quad$ Allgemeine Diskussion}

\subsection{Limitationen der Studien des Promotionsvorhabens}

Ziel des Promotionsvorhabens war es, den Einfluss von Haltung und Management auf das Tierwohlniveau in der Milchviehhaltung zu untersuchen. Hierzu wurden insgesamt 85 konventionelle Milchviehbetriebe mit Liegeboxenlaufställen und ohne Weidezugang zweimalig im Abstand von 6 Monaten mit Hilfe des Welfare Quality ${ }^{\circledR}$ Protokolls für Rinder hinsichtlich ihres Tierwohlniveaus bewertet und anschließend der Einfluss der verschiedenen Haltungs- und Managementfaktoren statistisch berechnet. Durch den Auswahlprozess der Teilnehmerbetriebe und die verwendeten Erhebungsmethoden ergaben sich für die Studien einzelne Limitationen, die im folgenden Abschnitt diskutiert werden:

Für die Untersuchung zum Einfluss der Bestandsgröße auf das Tierwohlniveau wurden Betriebe mit unterschiedlich hohen Tierzahlen in die Auswertung einbezogen. Die mittlere Bestandsgröße in der Stichprobe betrug 383 Milchkühe und lag damit sehr viel höher als der aktuelle Durchschnitt in Deutschland von 61 Milchkühen (Destatis, 2017). Die Streuung zwischen den Betrieben war beträchtlich, die Spannweite reichte von minimal 45 bis maximal 1629 Milchkühen. Im Rahmen der Betriebsakquise konnten keine Betriebe unterhalb einer Bestandsgröße von 45 Kühen mit Laufstallhaltung gefunden werden. Folglich wurden in der Stichprobe nicht alle in Deutschland vorhandenen Bestandsgrößenkategorien gleichermaßen abgebildet. Vor dem Hintergrund eines stetigen Strukturwandels und kontinuierlich wachsender Bestandsgrößen schränkt dies die Aussagekraft der Studien jedoch nicht wesentlich ein.

Die Teilnehmerbetriebe sollten alle über Liegeboxenlaufställe verfügen, um die Vergleichbarkeit der Haltungsbedingungen zwischen den Betrieben gewährleisten zu können. Die Bedeutung der Milchviehhaltung in Anbindeställen nimmt stetig ab, da diese als problematisch für das Tierwohlniveau angesehen wird (Wissenschaftlicher Beirat, 2015). Aus diesem Grund ist von einer sukzessiven Aufgabe der Anbindehaltung in Deutschland auszugehen und ihre Berücksichtigung in der Studie zum Einfluss steigender Bestandsgrößen auf das Tierwohlniveau demnach nicht gerechtfertigt. 
Desweiteren erfolgte die Betriebsauswahl auch nach der Höhe des Weideangebots für laktierende Kühe. Das Kriterium „Artgemäßes Verhalten“ besitzt innerhalb des WQP eine relativ hohe Gewichtung und Betriebe mit Weidegang würden systematisch höhere Tierwohlbeurteilungen erzielen. Dieser ressourcenbasierte Tierwohlindikator berücksichtigt jedoch nicht die Qualität der Weide (z.B. Schattenplätze, Wasserversorgung), so dass sich der Effekt des Weidegangs auf das Tierwohlniveau nur schwer ermessen lässt. Es wurde daher auf die Einbeziehung von Betrieben oberhalb des Schwellenwertes von 6 Stunden Weidegang pro Tag (Welfare Quality, 2012) verzichtet, um vergleichbare Rahmenbedingungen zwischen den Betrieben der Stichprobe sicherzustellen.

Bezüglich der Haltungseinrichtungen in den Milchviehställen wurde im Rahmen der Betriebsakquise kein konkretes Anforderungsprofil formuliert. Die tatsächliche Verteilung der unterschiedlichen Haltungsysteme (z.B. Liegeboxentyp, Fressplatztyp, Laufgangtyp) ließ sich aus der verfügbaren amtlichen Statistik nicht ableiten und demzufolge konnten auch keine repräsentativen Gruppen gebildet werden (Destatis, 2011). Daher wurden alle in der Praxis vorkommenden Haltungseinrichtungen wie z.B. Hoch- und Tiefboxen, Fressgitter und Nackenrohr oder Spaltenböden und planbefestigte Böden für die Teilnahme an der Studie zugelassen. Die Verteilung der Haltungseinrichtungen war zwischen den Betrieben relativ ausgeglichen. Lediglich der Anteil an Tiefboxen (74\%) war höher als der Anteil an Hochboxen (26\%). Insgesamt zeigte sich in der Stichprobe eine für die jeweilige Bestandsgrößenkategorie typische Verteilung der Haltungseinrichtungen, d.h. mit steigender Bestandsgröße nahm tendenziell die Anteile an planbefestigtem Boden und Nackenrohren am Futtertisch zu. Die Anteile an Hochund Tiefboxen blieben jedoch über die Bestandsgrößenklassen hinweg konstant.

Zur Einschätzung des Tierwohlniveaus auf den Betrieben wurde das Welfare Quality ${ }^{\circledR}$ Protokoll für Rinder angewandt. Das WQP gilt derzeit als das umfassendste Indikatorensystem zur Beurteilung des Tierwohls auf Betriebsebene (de Graaf et al., 2017b). Wie in der Literaturübersicht (Kapitel 2.4) näher beschrieben, wurden in den letzten Jahren jedoch vereinzelte methodische Probleme identifiziert (de Vries et al., 2013; Heath et al., 2014a,b; de Graaf et al., 2017b). Durch die spezifische Auswahl des Studiendesigns sollte der Einfluss der bekannten Schwachstellen im Rahmen des Promotionsvorhabens weitestgehend 
vermieden werden. Beispielsweise wurde der Fokus bei den statistischen Auswertungen in erster Linie auf die Ebene der Tierwohlindikatoren gelegt, d.h. es wurden die Effekte von Bestandsgröße, Bestandsdichte sowie Haltungs- und Managementfaktoren auf die einzelnen Tierwohlindikatoren wie z.B. Lahmheit, Sauberkeit oder soziale Interaktionen berechnet. Auf diese Weise konnte der Einfluss der in der Kritik stehenden Gewichtungsformeln innerhalb des Aggregationsprozesses reduziert werden (Sandoe et al., 2017; de Graaf et al., 2018).

Eine weitere Schwachstelle des WQP ist die Unterschätzung der Prävalenzen einzelner, in der Praxis selten auftretender Tierwohlindikatoren (z.B Durchfall). Der Stichprobenumfang müsste zur sicheren Identifizierung der Tierwohlprobleme deutlich größer sein als im WQP vorgegeben (van Os et al., 2018). Die Fragestellungen der Studien bezogen sich jedoch auf den Vergleich verschiedener Haltungssysteme. Die potentielle systematische Unterschätzung der Prävalenzen bei einzelnen Tierwohlindikatoren ist für die Beantwortung der gewählten Fragestellungen daher von untergeordneter Bedeutung. Lediglich in Studie I (Kapitel 3) könnte die Stichprobenziehung einen Einfluss auf die Tierwohlbeurteilungen ausgeübt haben, da die Anzahl untersuchter Kühe in kleineren Betrieben prozentual zur Bestandsgröße höher ausfiel als in größeren Betrieben. Die Ergebnisse der Studie zeigen jedoch bei den an einer Stichprobe erhobenen Tierwohlindikatoren keine systematisch höheren Prävalenzen in den kleineren Bestandsgrößenklassen. Demzufolge ist nicht von einer systematischen Verzerrung zulasten der kleineren Betriebe auszugehen.

In einigen Studien wurde eine mangelnde Beobachterübereinstimmung verschiedener Tierwohlindikatoren aus dem WQP nachgewiesen. Bei einzelnen Tierwohlindikatoren unterschieden sich die Bewertungen desselben Bild- und Videomaterials deutlich voneinander, d.h. die Beobachterübereinstimmung zwischen den Testpersonen ist als ungenügend einzustufen (Bokkers et al., 2012; Heath et al., 2014b; de Graaf et al., 2017a). Die Datenerhebung für die vorliegenden Studien wurde von einem einzelnen Prüfer durchgeführt, so dass sich die teilweise mangelnde Beobachterübereinstimmung (Inter-Beobachter-Reliabilität) nicht negativ auf die Ergebnisse der Untersuchungen ausgewirkt hat. Der Prüfer wurde in einem offiziellen Welfare Quality ${ }^{\circledR}$ Training an der Universität für Boden- 
kultur in Wien intensiv in der Methodik der Tierwohlbewertung geschult und wendete das vollständige WQP unter Anleitung auf mehreren Praxisbetrieben an. Im Zeitraum der Datenerhebung absolvierte der Prüfer zudem mehrere Forschungsaufenthalte an der Universität für Bodenkultur in Wien, um sich nachschulen zu lassen und die Anwendung der Tierwohlindikatoren mit erfahrenen Kollegen zu diskutieren. Aufgrund dieser intensiven Beschäftigung mit den Tierwohlindikatoren des WQP ist von einer relativ konstanten Erhebung über die Zeit (Intra-Beobachter-Reliabilität) auszugehen.

In den folgenden Abschnitten werden nun die Ergebnisse der drei Studien zum Einfluss von Bestandsgröße (Kapitel 3), Bestandsdichte (Kapitel 4) sowie Haltungs- und Managementfaktoren (Kapitel 5) miteinander verglichen und der Einfluss der verschiedenen Haltungsbedingungen und Managementpraktiken auf die Tierwohlindikatoren des WQP gemeinsam diskutiert. Dabei können nur diejenigen Tierwohlindikatoren berücksichtigt werden, die in mindestens zwei der vorliegenden Studien (I-III) statistisch ausgewertet worden sind und darüber hinaus die größte Tierwohlrelevanz besitzen.

6.1 Einflüsse von Haltungs- und Managementfaktoren auf die Tierwohlindikatoren des Prinzips „Gute Fütterung“

\section{Körperkondition}

Die Ergebnisse von Studie I (Kapitel 3) mit einem Durchschnitt von 12,7\% mageren Kühen (Spanne 9,0 bis 17,0\%) sind in Übereinstimmung mit anderen Studien (Popescu et al., 2014; Heath et al., 2014a; Zuliani et al., 2017). Der größte Anteil an mageren Kühen wurde in der vorliegenden Studie in der Bestandsgrößenklasse C2 (100-299 Kühe) gefunden, während die niedrigsten Werte von Gruppe C3 (300-499 Kühe) und Gruppe C4 ( $\geq 500$ Kühe) erzielt wurden. Mit steigender Bestandsgröße wurden geringere Anteile von mageren Kühen in der Herde auch von anderen Autoren nachgewiesen (de Vries et al., 2016; Adams et al., 2017). In größeren Betrieben können den Milchkühen verschiedene Futterrationen angeboten werden, die für den spezifischen Energiebedarf in bestimmten Laktationsstadien optimiert wurden (Bewley et al., 2008; Adams et al., 2017). 
Die Ergebnisse von Studie II (Kapitel 4) bestätigen die Resultate einer früheren Studie, bei der ebenfalls keine Effekte eines höheren Tier-Fressplatz-Verhältnisses (CFR) auf den Anteil magerer Tiere festgestellt wurden (Fregonesi and Leaver, 2002). Milchkühe können negative Effekte eines höheren CFR auf ihre Körperkondition offensichtlich vermeiden, indem sie ihr Fressverhalten ändern (Collings et al., 2011; Black et al., 2016). Beispielsweise wiesen Huzzey et al. (2006) und Krawczel et al. (2012) in überbelegten Ställen einen Rückgang der Fresszeit im Anschluss an die Futtervorlage nach, während gleichzeitig die tägliche Trockenmasseaufnahme konstant blieb. Diese Ergebnisse sind möglicherweise auf eine Verschiebung der Futteraufnahme in spätere Stunden des Tages oder einen Anstieg der Futteraufnahmerate zurückzuführen (Hosseinkhani et al., 2008).

In Studie III (Kapitel 5) wurden keine statistisch abgesicherten Zusammenhänge zwischen ausgewählten Haltungs- und Managementfaktoren und der Anzahl an mageren Kühen im Betrieb gefunden. Jedoch ergaben sich einige Hinweise auf mögliche Einflussfaktoren, die bei der Optimierung des Fütterungsmanagements nützlich sein könnten. Betriebe mit höheren Fütterungsraten (>1 Fütterung pro $\mathrm{Tag})$ hatten ein geringeres Risiko für magere Kühe $(p<0.20)$. Diese Assoziation wurde auch von DeVries et al. (2005) gefunden, die einen positiven Effekt einer mehrmaligen Fütterung auf das Futteraufnahmeverhalten beobachteten. Milchviehbetriebe aus der Gruppe mit hohem Tierwohl (HW) hatten im Vergleich zu Betrieben aus der Gruppe mit niedrigem Tierwohl (LW) häufiger mehr als eine Fütterungsgruppe und boten den Kühen somit verschiedene Rationen an. Ähnlich wie beim Bestandsgrößeneffekt können die Rationen so besser auf die Bedürfnisse der Tiere abgestimmt werden. Die Fütterung einer höheren Menge Kraftfutters $(>8,5 \mathrm{~kg} / \mathrm{Tag})$ vermindert das Vorkommen magerer Kühe in der Herde. Zu ähnlichen Ergebnissen kamen Berry et al. (2006), die schwerere Kühe in Gruppen mit einer energiereichen Fütterung fanden. Nichtsdestotrotz sollten die Kraftfuttermengen nicht zu hoch angesetzt werden, da eine Verfettung der Tiere zu Stoffwechselstörungen führen kann (Roche et al., 2009). 


\section{Wasserversorgung}

Die durchschnittliche Troglänge pro Tier in Studie I war höher in Betrieben mit einer Bestandsgröße oberhalb von 300 Kühen. In den beiden größeren Gruppen C3 und C4 wurden im Schnitt mehr als 7,5 cm Troglänge pro Tier angeboten. Dieser Wert ist nach Angaben des WQP als ausreichend anzusehen $(>6 \mathrm{~cm})$. Die kleineren Gruppen C1 und C2 boten ihren Tieren hingegen weniger Wasserfläche an und erreichten daher im Durchschnitt nur den Schwellenwert (4-6 cm) für eine teilweise ausreichende Wasserversorgung (Welfare Quality, 2012). Oftmals war in den kleineren Betrieben zwar die Wasserversorgung in der größeren Hauptgruppe (z.B. Frischlaktierende) zufriedenstellend, aber die kleinere Nebengruppe (z.B. Altmelker) war hinsichtlich des Wasserangebots unterversorgt. Laut WQP wird stets die am schlechtesten bewertete Gruppe als Maßstab für das Wasserangebot verwendet, so dass die kleineren Betriebe in diesem Kriterium vielfach niedrigere Punktzahlen erzielten (Welfare Quality, 2012). In anderen Studien wurden ähnliche Bewertungen für ausreichend (43\%), teilweise ausreichend (35\%) und nicht ausreichend (22\%) gefunden (de Vries et al., 2013; Heath et al., 2014b; De Boyer des Roches et al., 2014).

Die Troglänge pro Kuh in Studie II war auf einem vergleichbaren Niveau wie in der Literatur angegeben. In einer nordamerikanischen Studie wurde eine hohe Variabilität zwischen den Betrieben in Bezug auf die Wasserversorgung der Milchkühe nachgewiesen. Im Mittel wurden den Tieren 6 bis $8 \mathrm{~cm}$ Troglänge angeboten, wobei die Spannweite mit 1-24 cm sehr groß ausfiel (von Keyserlingk et al., 2012). Zwischen den Gruppen mit unterschiedlichem Verkehrsflächenangebot unterschieden sich die angebotenen Wasserflächen signifikant. Die Betriebe aus den Gruppen W1 und W2 überschritten im Durchschnitt den Schwellenwert für eine ausreichende Wasserversorgung. Im Gegensatz dazu boten die Betriebe aus Gruppe W3 nur eine teilweise ausreichende Wasserversorgung an. Bei der Wasserverfügbarkeit handelt es sich um einen ressourcenorientierten Indikator, daher ist die tatsächliche Wasseraufnahme der Milchkühe nicht bekannt (de Vries et al., 2013). Insbesondere rangniedere Tiere können von limitierten Wasserstellen vertrieben werden und daher ist es empfehlenswert zur Vermeidung von Stress zusätzliche Tröge aufzustellen (Proudfoot und Habing, 2015). 
6.2 Einflüsse von Haltungs- und Managementfaktoren auf die Tierwohlindikatoren des Prinzips „Gute Haltung“

\section{Abliegedauer}

Die durchschnittliche Abliegedauer rangierte in Studie I zwischen 5,3 und 6,0 Sekunden und wurde signifikant von der Bestandsgröße beeinflusst. Unter Berücksichtigung der im WQP angegebenen Warn- (5,2 Sek.) und Alarm- (6,3 Sek.)Schwellenwerte wurde die Abliegezeit in den meisten Betrieben als Tierwohlproblem eingestuft. Vergleichbare Werte wurden beispielsweise in Frankreich mit 5,9 Sek. (De Boyer des Roches et al., 2014), Großbritannien mit 5,2 Sek. (Heath et al., 2014a), Dänemark mit 6,0 Sek. (Andreasen et al., 2014) und Österreich mit 5,9 Sek. (Tremetsberger et al., 2015) gefunden. Die beobachtete Variabilität in Bezug auf die Abliegevorgänge könnte durch unterschiedliche Haltungsbedingungen hervorgerufen worden sein (Plesch et al., 2010). Die Betriebe aus der Bestandsgrößenklasse $\mathrm{C} 3$ erreichten deutlich geringere Werte im Vergleich zu den Betrieben aus der Gruppe C1. Diese Ergebnisse könnten zumindest teilweise mit dem höheren Anteil an Tiefboxen (90\%) in C3, verglichen mit einem geringeren Anteil an Tiefboxen (65\%) in C1 erklärt werden. Tiefboxen bieten den Kühen mehr Komfort und könnten die Abliegedauer auf diese Weise reduzieren (Wechsler et al., 2000).

In Studie II wurde kein signifikanter Einfluss des Tier-Liegeboxen-Verhältnisses (CSR) auf die Abliegedauer nachgewiesen. Die drei Bestandsdichtenklassen erzielten mit 5,9 Sekunden (S1), 5,7 Sekunden (S2) und 5,8 Sekunden (S3) Ergebnisse auf einem vergleichbaren Niveau. Die durchschnittliche Abliegedauer lag in allen drei Gruppen oberhalb des Warn-Schwellenwertes, der ein moderates Tierwohlproblem im Bereich des Liegekomforts anzeigt (Welfare Quality, 2012). Möglicherweise wurde die relativ lange Abliegedauer durch nicht an die Körpergröße der Kühe angepasste Liegeboxenabmessungen beeinflusst, da die Tiere durch falsche Dimensionierungen der Liegeboxenabtrennungen, wie z.B. einem zu niedrigen Abstand des Nackenrohres zur Kotkante oder einem zu niedrig angebrachtem Liegeboxenbügel, beim Abliegevorgang gestört werden könnten (Veissier et al., 2004). Darüber hinaus sind auch schmerzhafte Gesundheitsprobleme als Einflussfaktor für diesen Tierwohlindikator denkbar. In einer rumäni- 
schen Studie wurde eine starke Korrelation zwischen der Abliegedauer und Kühen mit Lahmheit, Integumentschäden oder Mastitis festgestellt (Popescu et al., 2013). Der Abliegevorgang ist bei diesen gesundheitlich eingeschränkten Kühen in der Regel mit großen Schmerzen verbunden und sie legen oftmals auf den Karpalgelenken ruhend eine kleinere Pause während des Abliegens ein. Aufgrund der begrenzten Anzahl an vollständig beobachteten Abliegevorgängen können diese einzelnen Ausreißer die durchschnittliche Abliegedauer eines Betriebes deutlich verlängern.

\section{Verschmutzungen}

In den meisten Milchviehbetrieben aus Studie I wird der Alarm-Schwellenwert für Verschmutzungen der Unterbeine (50\%) und Oberbeine sowie Euter (20\%) weit überschritten (Welfare Quality, 2012). Die klinische Untersuchung der Tiere ergab im Durchschnitt einen Anteil von 43,6\% verschmutzten Eutern, von 65,4\% verschmutzten Oberbeinen und von $51,1 \%$ verschmutzten Unterbeinen. Vergleichbare Ergebnisse für verschmutzte Ober- und Unterbeine wurden auch von anderen Autoren berichtet (De Boyer des Roches et al., 2014; Heath et al., 2014a; Zuliani et al., 2017). Der Anteil Tiere mit verschmutztem Euter war in der vorliegenden Studie niedriger als bei anderen Studien, die z.T. mehr als 50\% verschmutzte Euter mit einer Spanne von 2 bis 98\% nachwiesen (Heath et al., 2014a; Benatallah et al., 2015). Der prozentuale Anteil an verschmutzten Unterbeinen wurde von der Bestandsgröße beeinflusst, jedoch nicht der Anteil an Kühen mit verschmutzten Oberbeinen oder verschmutzten Eutern. Der deutliche Unterschied von 57,2\% verschmutzter Unterbeine in C1 zu 41,2\% in C3 könnte wie auch schon im Fall der Abliegedauer vom höheren Anteil an Tiefboxen in C3 (90\%) im Vergleich zu C1 (65\%) erklärt werden. Tiefboxen haben einen höheren Einstreuanteil und weisen dadurch eine wesentlich höhere Absorptionskapazität auf (de Vries et al., 2015; Cook et al., 2016). Darüber hinaus haben Tiefboxen im Gegensatz zu Hochboxen eine höhere Kotkante, um das Einstreumaterial in den Boxen zu fixieren. Dadurch liegen die Schwänze der Kühe seltener in den verkoteten Lauf- oder Fressgängen und es besteht ein geringeres Risiko den eigenen Körper mit der verschmutzten Schwanzquaste zu besudeln. 
Die prozentualen Anteile verschmutzter Tiere war auch in Studie II auf einem sehr hohen Niveau. Im Mittel wurden 52,9\% verschmutzte Unterbeine, 72,3\% verschmutzte Oberbeine und 37,1\% verschmutzte Euter gefunden. Ein höheres Tier-Liegeboxen-Verhältnis (CSR) könnte die Sauberkeit der Milchkühe möglicherweise beeinträchtigen (Krawczel et al., 2012a). Im Normalfall vermeiden es Kühe sich in feuchte und dreckige Liegeboxen zu legen. Unter restriktiven Bedingungen sind sie jedoch dazu gezwungen, sich auch in verschmutzte Liegeboxen niederzulassen (Fregonesi et al., 2007; Ito et al., 2014). Einen Einfluss der CSR auf die Sauberkeit der Milchkühe konnte in dieser Studie nicht bestätigt werden. Krawczel et al. (2012a) untersuchten den Zusammenhang zwischen einem mittleren und einem hohen CSR und verschiedenen Verhaltens- und Hygieneparametern. Die Autoren beobachteten keinen Effekt der Behandlung auf den Euteroder Bein-Hygiene-Score (Krawczel et al., 2012a). Zu ähnlichen Ergebnissen kamen auch Lombard et al. (2010), die keine Assoziation zwischen der Anzahl an Kühen pro 100 Liegeboxen und dem Verschmutzungsgrad in nordamerikanischen Milchviehbetrieben nachweisen konnten.

\subsection{Einflüsse von Haltungs- und Managementfaktoren auf die Tier- wohlindikatoren des Prinzips „Gute Gesundheit“}

\section{Integumentschäden}

Schwere Integumentschäden (Läsionen/Schwellungen) wurden bei 31,6\% der Milchkühe in Studie I beobachtet. Diese Ergebnisse sind ähnlich den Prävalenzen von $39,2 \%$ in französischen (Coignard et al., 2013), 37,6\% in niederländischen (de Vries et al., 2013) und 29,8\% in britischen (Heath et al., 2014a) Milchviehbetrieben. Ein Einfluss der Bestandsgröße auf die Anzahl an Läsionen und Schwellungen konnte in dieser Studie nicht nachgewiesen werden, d.h. der Anteil an Verletzungen war in kleineren und größeren Betrieben auf einem vergleichbaren Niveau. Ein signifikanter Effekt der verschiedenen Haltungs- und Managementeinrichtungen auf die Häufigkeit von Integumentschäden wurde in Studie III nicht belegt, obwohl diese der Literatur zufolge zu den größten Einflussfaktoren zählen (Nash et al., 2016; Adams et al., 2017). Insbesondere Hochboxen mit Gummimatten gelten als Risikofaktoren für Läsionen, da sich die Kühe auf der harten und rauen Oberfläche verletzen können (Wechsler et al. 2000, Haskell et 
al., 2006; Brenninkmeyer et al., 2013). Falsch dimensionierte Liegeboxenabmessungen können auch zu einer erhöhten Prävalenz von Integumentschäden in Milchviehbetrieben beitragen (Kester et al., 2014). Beispielsweise wurden in einer Untersuchung weniger Tarsalgelenksverletzungen beobachtet, wenn der Abstand zwischen Bugbrett und Kotstufe mehr als $178 \mathrm{~cm}$ betrug (Potterton et al., 2011). Desgleichen wurden weniger Tiere mit Läsionen und Schwellungen nachgewiesen, wenn der Abstand zwischen dem Nackenrohr und der Kotkante eine Länge von $196 \mathrm{~cm}$ überschritt (Kielland et al., 2009). Die Gestaltung und das Management der Liegeboxen sind für das Auftreten von Integumentschäden sicherlich von großer Bedeutung. Dennoch könnten auch andere Haltungsfaktoren wie z.B. die Fressplatzgestaltung für die beobachteten Hautverletzungen verantwortlich sein. Zaffino Heyerhoff et al. (2014) untersuchten den Einfluss der Fressplatzhöhe auf die Integumentschäden bei Milchkühen und stellten fest, dass die Wahrscheinlichkeit von Nackenschwellungen bei einer niedrigen Fressplatzhöhe $(<149 \mathrm{~cm})$ deutlich größer war. Trotz der in der Literatur dokumentierten Effekte der Haltungseinrichtungen auf Integumentschäden, war keiner der untersuchten Einflussfaktoren in der statistischen Auswertung signifikant. Möglicherweise spielte das Management auf den Betrieben (z.B. Liegeboxeneinstreu oder Fütterungsfrequenz) eine größere Rolle für die Verletzungshäufigkeit als die Haltungseinrichtungen allein (Kester et al., 2014).

\section{Lahmheiten}

Es wurde kein direkter Einfluss der Bestandsgröße auf die Lahmheitsprävalenz in Studie I gefunden. Dieses Ergebnis ist in Übereinstimmung mit anderen Untersuchungen, bei denen sich die Bestandsgröße nicht als Risikofaktor für Lahmheiten erwiesen hatte (Barker et al., 2010; Fabian et al., 2014). Im Gegensatz dazu beobachteten Alban et al. (1995) und de Vries et al. (2014) einen positiven Zusammenhang zwischen Bestandsgröße und Lahmheit bei Milchkühen. Dies wurde von den Autoren mit einer höheren Mechanisierung und geringerer Aufmerksamkeit für Einzeltiere begründet. Andere Wissenschaftler fanden hingegen eine negative Beziehung zwischen Bestandsgröße und Lahmheit und erklärten dies mit einem professionelleren Herdenmanagement (Dippel et al., 2009; Chapinal et al., 2013; Solano et al., 2015). Der Anteil an hochgradig lahmen Tieren war in Studie I mit 22,3\% deutlich höher als in anderen europäischen Studien (Ø 5\%) 
(de Vries et al., 2013; Heath et al., 2014a). Dieser Unterschied könnte auf die spezifischen Haltungsbedingungen in den Teilnehmerbetrieben zurückzuführen sein. Durch die Betriebsauswahl wurden mehrere Risikofaktoren für die Entstehung von Lahmheiten kombiniert (Dippel et al., 2009; Solano et al., 2015). Beispielsweise wurden die Milchkühe in Liegeboxenlaufställen gehalten und waren im Gegensatz zu Kühen in anderen Haltungssystemen ständig in Kontakt mit verschmutzten Laufflächen. Dadurch könnte die Klauengesundheit beeinträchtigt worden sein (Haskell et al., 2006; Coignard et al., 2013; Popescu et al., 2014). Die Milchviehbetriebe boten ihren Tieren zudem keinen Weidegang an und die Klauen konnten sich dadurch nicht auf dem weichen Untergrund regenerieren (Cook et al., 2016; de Graaf et al., 2017a).

Im Rahmen der zweiten Studie wurde ein Zusammenhang zwischen einem hohen Tier-Liegeboxen-Verhältnis (>105\%) und einer hohen Lahmheitsprävalenz nachgewiesen. Dies könnte durch Verhaltensänderungen aufgrund der Überbelegung erklärt werden (Espejo und Endres, 2007; Hill et al., 2009). Falk et al. (2012) wiesen längere Standzeiten in den Laufgängen nach, wenn sich das TierLiegeboxen-Verhältnis verschlechterte. Ähnliche Ergebnisse wurden auch von anderen Autoren gefunden (Fregonesi et al., 2007; Winckler et al., 2015). Inaktive Standzeiten wiederum erhöhen das Risiko für Lahmheit, da die Klauen sich durch den ständigen Kontakt mit den verschmutzten Laufwegen verändern können (Webster, 2001). Ein niedriges Platzangebot wirkte sich in Studie II überraschenderweise positiv auf die Lahmheitsprävalenz aus. Die niedrigsten Werte wurden in Gruppe W3 nachgewiesen. Dies könnte ebenfalls auf die bereits erwähnten Verhaltensänderungen zurückzuführen sein. In überbelegten Ställen mit geringem Platzangebot versuchen insbesondere rangniedere und kranke Tiere Konflikten aus dem Weg zu gehen und ziehen sich daher vermehrt in die Liegebereiche zurück (Estevez et al., 2007; Winckler et al., 2015). Durch diese Vermeidungsstrategie kommen die Tiere seltener mit dem verschmutzten Boden in Berührung und die Klauen können regelmäßig abtrocknen. Dies könnte zu der besseren Klauengesundheit beigetragen haben. Im Gegensatz dazu haben Dippel et al. (2009) und Espejo und Endres (2007) keinen Einfluss des Platzangebots auf Lahmheitsprävalenzen feststellen können. 
Ein hohes Tier-Liegeboxen-Verhältnis (>105\%) wurde auch in Studie III als potentieller Risikofaktor für Lahmheitsprobleme identifiziert $(p<0,20)$. Darüber hinaus zeigte sich ein möglicher positiver Einfluss der Klauenpflegefrequenz auf den Anteil lahmer Kühe $(p<0,20)$. Höhere Klauenpflegefrequenzen ( $>2,5 \mathrm{x} / \mathrm{Jahr}$ ) waren im Vergleich zu niedrigeren ( $<2,5 \mathrm{x} / \mathrm{Jahr}$ ) mit einem geringeren Risiko an Lahmheitsfällen assoziiert. Diese Ergebnisse sind vergleichbar zur Untersuchung von Espejo und Endres (2007), die einen positiven Effekt einer häufigeren Klauenpflege beobachten konnten. Im Gegensatz dazu wurde in einer nordamerikanischen Studie kein Zusammenhang zwischen der Klauenpflegefrequenz und der Lahmheitsprävalenz nachgewiesen (Chapinal et al., 2013). Milchviehställe mit Spaltenböden stellten einen potentiellen Risikofaktor für vermehrte Lahmheitsfälle dar ( $p<0,20)$. Dippel et al. (2009) und Rouha-Mülleder et al. (2009) fanden ebenfalls mehr lahmende Tiere in Ställen mit Spaltenböden, als in Ställen mit planbefestigen Böden und erklärten dieses Ergebnis mit hervortretenden Kanten und variablem Bodenniveau bei älteren Spaltenböden. Keine Assoziation zwischen dem Laufgangstyp und dem Anteil lahmer Tieren wurde jedoch in einer kanadischen Studie beobachtet (Solano et al., 2015). Die regelmäßige Anwendung eines Klauenbades ist der einzige statistisch abgesicherte Einflussfaktor auf den Anteil lahmer Kühe aus den Bereichen Haltung und Management $(p<0,05)$. Betriebe mit geringeren Lahmheitsprävalenzen nutzten das Klauenbad regelmäßig, während es in Betrieben mit höheren Lahmheitsprävalenzen seltener zum Einsatz kam. Ein Rückgang der Lahmheitsfälle bei höheren Klauenbadfrequenzen wurde auch von Chapinal et al. (2013) gefunden. Demgegenüber konnte von anderen Autoren kein Zusammenhang zwischen Klauenbadanwendung und Lahmheitsprävalenz nachgewiesen werden. (Espejo und Endres, 2007; Adams et al., 2017).

\section{Mastitisinzidenz}

In den Betrieben von Studie I und II wurden im Durchschnitt ein Anteil von 21\% Milchkühen mit Verdacht auf Euterentzündungen ( $>400.000$ Zellen/ml Milch) beobachtet. Vergleichbare Ergebnisse wurden auch in anderen Studien nachgewiesen. Andreasen et al. (2014) beschrieben eine Überschreitung der Warnschwelle $(8,8 \%)$ durch 11 Betriebe und eine Überschreitung der Alarmschwelle (17,5\%) 
durch 29 Betriebe, wobei die Gesamtstichprobe aus 44 dänischen Milchviehbetrieben bestand. Coignard et al. (2013) stellten eine mittlere Mastitisinzidenz bei 20,6\% (Spannweite 2,0 - 46,6\%) der Milchkühe fest. Deutlich geringere Prävalenzen wurden mit $11,1 \%$ betroffenen Kühen in niederländischen (de Vries et al., 2013) und 15,5\% betroffenen Kühen in britischen (Heath et al., 2014a) Milchviehbetrieben berichtet. Es wurde kein signifikanter Effekt der Bestandsgröße auf die Mastitisinzidenz in Studie I nachgewiesen. In allen Bestandsgrößenkategorien bewegte sich der Anteil an Kühen mit Euterentzündungen auf einem vergleichbaren Niveau. Diese Ergebnisse stimmen mit den Angaben in anderen Studien überein (Ivemeyer et al., 2011; Schewe et al., 2015). Im Gegensatz dazu beobachteten einige Autoren mit steigenden Bestandsgrößen ein erhöhtes Risiko an Mastitiden zu erkranken und führten dies u.a. auf ein potentiell höheres Infektionsrisiko in größeren Herden zurück (Lievaart et al., 2007; Archer et al., 2013). In anderen Studien wurde hingegen ein geringeres Risiko für Euterentzündungen in größeren Betrieben postuliert. Die Autoren begründeten diesen positiven Zusammenhang mit verschiedenen Managementmaßnahmen wie z.B. standardisierte Melkhygiene oder systematischer Merzung euterkranker Tiere (Oleggini et al., 2001; Ingham et al., 2011). Die widersprüchlichen Literaturangaben sind möglicherweise auf unterschiedliche Studiendesigns zurückzuführen. Die zitierten Studien variierten deutlich hinsichtlich der untersuchten Bestandsgrößen, Milchleistungen, Milchviehrassen und den verwendeten Indikatoren für die Mastitisdetektion. Daher ist ein direkter Vergleich der Ergebnisse zwischen den Studien nicht möglich.

Ein signifikanter Effekt des Platzangebots wurde in Studie II nachgewiesen. Milchviehbetriebe aus Gruppe W1 hatten im Vergleich zu Gruppe W2 deutlich höhere Mastitisinzidenzen. Die Betriebe in Gruppe W3 unterschieden sich nicht von den beiden anderen Gruppen. Diese Ergebnisse könnten mit einem höheren Stresslevel in überbelegten Ställen erklärt werden, die zu immnunologischen Reaktionen führen können (Chebel et al., 2016). Eine Überbelegung erhöht dabei nicht nur den sozialen Stresslevel, sonden beeinflusst auch die Übertragung von pathogenen Keimen. Daher sind die Milchkühe in überbelegten Ställen einem erhöhten Erkrankungsrisiko ausgesetzt (Proudfoot und Habing, 2015). Darüber 
hinaus sind die Milchkühe in Gruppe W1 hohen Tier-Liegeboxen- und Tier-Fressplatzverhältnissen ausgesetzt. In überbelegten Ställen konkurrieren die Kühe um limitierte Ressourcen wie Liegeboxen oder Fressplätze und ändern vielfach ihr Verhalten, um Auseinandersetzungen mit anderen Kühen zu entgehen. Beispielsweise beobachteten einige Autoren bei steigender Bestandsdichte eine Reduktion der Futteraufnahme nach dem Melken und einen Anstieg der Liegezeiten im selben Zeitraum (Grant und Albright, 2001; Hill et al., 2009). Diese Verhaltensänderung könnte das Risiko von Euterentzündungen erhöhen, da die Zitzen nach dem Melken noch geöffnet sind und somit anfälliger für die Infektion mit Umweltkeimen aus den Liegeboxen (Fregonesi et al., 2007; Sova et al., 2013).

In der logistischen Regressionsanalyse von Studie III waren drei potentielle Einflussfaktoren aus den Bereichen Haltung und Management mit einer niedrigen Mastitisinzidenz assoziiert. In Betrieben mit vermehrten Euterentzündungen wurden häufiger antibiotische Trockenstehertherapien durchgeführt, als in Betrieben mit wenigen betroffenen Tieren. Diese beobachtete Assoziation bestätigt die Ergebnisse einer Fall-Kontroll-Studie aus Schweden (Nyman et al., 2007). Die Autoren berichteten, dass Milchkühe von Betrieben mit einem hohen Anteil an klinischen Mastitiden im Vergleich zu Milchkühen von Betrieben mit einem geringen Anteil an klinischen Mastitiden häufiger in der Trockenstehphase antibiotisch behandelt wurden (Nyman et al., 2007). Diese Ergebnisse indizieren allerdings keinen kausalen Zusammenhang zwischen antibiotischer Trockenstehertherapie und einem hohen Anteil an Kühen mit Mastitis. Landwirte mit hohen klinischen Erkrankungsraten behandeln ihre Kühe wahrscheinlich routinemäßig, um weitere Infektionen zu verhindern (Barkema et al., 1999). Im Gegensatz dazu wurde ein geringeres Risiko für subklinische Mastitiserkrankungen mit einer routinemäßigen Anwendung einer antibiotischen Trockensteherbehandlung (OR 0,5) im Vergleich zu unregelmäßiger Antibiotikagabe gefunden (Doherr et al., 2007). Höhere Melkfrequenzen ( $>2 \times / T a g$ ) beeinflussten den Gehalt an somatischen Zellen in der Milch positiv, d.h. es wurden höhere Zellzahlgehalte bei mehr als 2 Melkzeiten nachgewiesen. Dieses Ergebnis war überraschend, da höhere Melkfrequenzen aufgrund der häufigeren Entleerung des Euters in der Literatur als förderlich für die Eutergesundheit beschrieben werden (Hovinen und Pyörälä, 2011). 
Geringere Anteile an Kühen mit Mastitisinzidenz wurden in Betrieben mit drei Melkzeiten am Tag im Vergleich zu Betrieben mit zwei Melkzeiten am Tag nachgewiesen (Smith et al., 2002). Diese widersprüchlichen Ergebnisse könnten auf die unterschiedlichen Melksysteme in Studie III zurückzuführen sein. Milchviehbetriebe mit automatischem Melksystem (AMS) waren mit einem höheren Risiko für Euterentzündungen assoziiert, verglichen mit Betrieben mit einem konventionellen Melkstand. AMS sind einerseits durch höhere Melkfrequenzen gekennzeichnet und stellen anderseits einen Risikofaktor für die Eutergesundheit dar (Hovinen and Pyörälä, 2011; Jacobs and Siegford, 2012). Im Vergleich zu konventionellen Melkständen sind AMS mit einer höheren Wahrscheinlichkeit für Euterentzündungen verbunden. Grund hierfür ist die teilweise mangelnde Zitzenreinigung und das höhere Infektionsrisiko durch die vielfach geteilten Zitzenbecher (Dohmen et al., 2010; Hovinen und Pyörälä, 2011; Barkema et al., 2015).

\subsection{Einflüsse von Haltungs- und Managementfaktoren auf die Tier- wohlindikatoren des Prinzips „Artgemäßes Verhalten“}

\section{Agonistische Interaktionen}

Ein signifikanter Effekt der Bestandsgröße auf die Anzahl agonistischer Interaktionen wurde in Studie I nachgewiesen. Die häufigsten Auseinandersetzungen zwischen Milchkühen wurden in der kleinsten Gruppe $\mathrm{C} 1$ festgestellt. Die höhere Anzahl an Vertreibungen kann auf geringeres Platzangebot in engen Laufgängen der meist älteren Ställe von Gruppe C1 oder auf Konflikte um limitierte Ressourcen wie z.B. Tröge, Kraftfutterstationen oder Kuhbürsten zurückgeführt werden (de Vries et al., 2015). Insgesamt waren die Anzahl Vertreibungen in allen Bestandsgrößenklassen jedoch auf einem relativ niedrigen Niveau $(0,1$ bis 0,2 Vertreibungen pro Kuh und Stunde), im Vergleich zu einem höheren Wert von 0,4 Vertreibungen pro Kuh und Stunde in den Niederlanden (de Vries et al., 2015), in Belgien (de Graaf et al., 2017a) und in Großbritannien (Heath et al., 2014a). Die Ergebnisse in Studie II stehen im Widerspruch zu Angaben aus der Literatur. Höhere Tier-Fressplatz-Verhältnisse (CFR) sind üblicherweise mit vermehrten agonistischen Interaktionen assoziiert (Chebel et al., 2016). Krawczel et al. (2012b) verglichen beispielsweise das Sozialverhalten am Futtertisch und wiesen einen kontinuierlichen Anstieg der Vertreibungen mit steigendem CFR nach. 
Zu einem ähnlichen Ergebnis gelangten Huzzey et al. (2006) die von einer höheren Anzahl an Vertreibungen mit abnehmendem Fressplatzangebot berichten. Entgegen den Erwartungen wurden in Studie II jedoch der größte Anteil an Kopfstößen in Gruppe F1 gefunden, im Vergleich zu den Gruppen F2 und F3. Die Anzahl an Vertreibungen unterschied sich jedoch nicht zwischen den Gruppen. Die abweichenden Ergebnisse zu den Literaturangaben könnten durch verschiedene methodische Ansätze zur Erhebung des Sozialverhaltens erklärt werden. Die agonistischen Interaktionen wurden im Gegensatz zu vielen anderen Studien nicht nur am Futtertisch beobachtet, sondern in verschiedenen Segmenten des gesamten Stalls (Welfare Quality, 2012). Der größte Anteil an Kopfstößen trat während der Auseinandersetzungen um limitierte Ressourcen wie z.B. Kraftfutterstationen auf. Diese waren besonders häufig in der Gruppe der kleineren Betriebe in F1 zu finden, während die größeren Betriebe in der Regel eine TotaleMisch-Ration (TMR) verfütterten.

Die Ergebnisse in Studie III deuten ebenfalls auf einen Zusammenhang zwischen limitierten Ressourcen und der Anzahl agonistischer Interaktionen hin. Milchviehbetriebe mit mittleren (95\%-105\%) bis hohen (>105\%) Tier-Liegeboxen-Verhältnissen hatten ein höheres Risiko für agonistische Interaktionen. Diese Ergebnisse sind in Übereinstimmung mit früheren Studien (Fregonesi et al., 2007; Winckler et al., 2015). Darüber hinaus wurde auch ein höherer Anteil an agonistischen Interaktionen in Betrieben mit einem niedrigen (<105\%), im Vergleich zu mittleren (105-118\%) und hohen (>118\%) Tier-Fressplatz-Verhältnissen gefunden. Diese Ergebnisse entsprachen wie auch in Studie II nicht den Literaturangaben und können mit einer abweichenden Erhebungsmethodik erklärt werden (Huzzey et al., 2006; Krawczel et al., 2012b). Daneben wurden in dieser Studie auch noch Assoziationen zwischen limitierten Ressourcen und dem Anteil an agonistischen Interaktionen gefunden. Die Präsenz einer Kraftfutterstation und eine geringe Wasserverfügbarkeit ( $<4,7 \mathrm{~cm}$ pro Kuh) waren positiv mit der Anzahl an Kopfstößen und Vertreibungen assoziiert. Hingegen wurden keine Zusammenhänge zwischen der Anwesenheit von Kuhbürsten und den Ergebnissen innerhalb des Kriteriums "Soziales Verhalten" gefunden. In der Literatur wurde jedoch ein Anstieg der agonistischen Interaktionen mit der Anwesenheit einer Kuhbürste beschrieben (Val-Laillet et al., 2008; de Vries et al., 2015). 


\section{Qualitative Verhaltensbeurteilung}

Der Ansatz der qualitativen Verhaltensbeurteilung (QBA) wurde angewandt, um den emotionalen Zustand der Milchviehherde zu beschreiben (Welfare Quality, 2012). Das zugrundeliegende Konzept des QBA wurde von Francoise Wemelsfelder und Kollegen entwickelt (Wemelsfelder et al., 2001). Geschulte Beobachter bewerten dabei den emotionalen Zustand der gesamten Herde durch die Betrachtung der Körpersprache der Tiere (Wemelsfelder, 2007; Andreasen et al., 2013). Die Eignung dieser Methode wird in der Wissenschaft kontrovers diskutiert, da sie möglicherweise unzureichende Inter-Beobachter-Reliabilitäten aufweist (Andreasen et al., 2014). Einerseits wurden gute Beobachterübereinstimmungen bei Schafen (Phytian et al., 2013), Milchkühen (Rousing und Wemelsfelder, 2006) und Kälbern (Brscic et al., 2009) gefunden. Andererseits zeigten sich nur niedrige bis mittlere Beobachterübereinstimmungen in anderen Studien zum Milchvieh (Bokkers et al., 2012; de Graaf et al., 2017a,b). Nichtsdestrotz wurde diese Methode in das WQP integriert, da derzeit keine geeignete Alternative zur Beurteilung der positiven Emotionen zur Verfügung steht (Napolitano et al., 2009; Heath et al., 2014b).

Die Ergebnisse des QBA lagen in Studie I auf einem relativ hohen Niveau. In allen Bestandsgrößenkategorien wurden Werte oberhalb von 70 Punkten vergeben, wobei eine Einstufung zwischen 0 Punkten (schlechter emotionaler Zustand) bis 100 Punkte (exzellenter emotionaler Zustand) möglich war (Welfare Quality, 2012). Vergleichbare Bewertungen des emotionalen Zustands wurden auch in anderen Studien gefunden. Benatallah et al. (2015) wiesen im Schnitt 85,5 Punkte in Algerien und de Graaf et al. (2017a) 68,9 Punkte zu Beginn und 56,4 Punkte zum Ende der Stallperiode in Belgien nach. Geringfügig niedrigere Bewertungen wurden von anderen Arbeitsgruppen in Großbritannien (50,0 Punkte), Frankreich (49,0 Punkte) und Rumänien (58,4 Punkte) vergeben (Heath et al., 2014a; de Boyer des Roches et al., 2014; Stankovic et al., 2014). Die vorherigen Auswertungen in Studie II zur Anzahl von Kopfstößen und Vertreibungen zeigten keinen Anstieg des agonistischen Verhaltens mit höheren Tier-Fressplatz-Verhältnissen. Milchkühe versuchen agonistische Interaktionen mit anderen Tieren normalerweise zu vermeiden und ändern daher in überbelegten Stäl- 
len oftmals ihr Fressverhalten (Hill et al., 2009). Die Milchkühe zeigten beispielsweise vermehrtes inaktives Stehen, da sie auf einen Platz am Futtertisch warten mussten (Huzzey et al., 2006). Diese Verhaltensänderung aufgrund von überbelegten Ställen könnte das Tierwohl jedoch beeinträchtigen. Milchkühe bevorzugen synchrones Fressverhalten und könnten von der Unterdrückung des natürlichen Verhaltens negativ beeinflusst werden (Spinka, 2006; Krawczel et al., 2012b). Darüber hinaus führt ein permanent hohes Stressniveau zu Beeinträchtigungen der Gesundheit und des Verhaltens (Petherick und Phillips, 2009). In überbelegten Ställen könnte daher möglicherweise ein schlechterer emotionaler Zustand nachgewiesen werden. Diese Hypothese ließ sich mit den Ergebnissen von Studie II jedoch nicht belegen. Die niedrigsten QBA-Bewertungen wurden in Gruppe F1 gefunden, d.h. in Betrieben mit dem umfangreichsten Fressplatzangebot wurden die geringsten positiven Emotionen in der Herde beobachtet. Wahrscheinlich hatten andere Haltungs- und Managementfaktoren einen negativen Einfluss auf den emotionalen Zustand der Milchkühe. Die Betriebe von Gruppe $\mathrm{F} 1$ verfügten über ältere Warmställe mit dem höchsten Anteil an Hochboxen. Diese Faktoren könnten zu den relativ niedrigen QBA-Bewertungen beigetragen haben, da sie der Literatur zufolge das Tierwohlniveau nachhaltig beinträchtigen können (Dippel et al., 2009; Ito et al., 2014).

\subsection{Literaturverzeichnis}

Adams, A.E., J.E. Lombard, C.P. Fossler, I.N. Román-Muñiz, and C.A. Kopral. 2017. Associations between housing and management practices and the prevalence of lameness, hock lesions, and thin cows on US dairy operations. J. Dairy Sci. 100:2119-2136. https://doi.org/10.3168/jds.201611517.

Alban, L. 1995. Lameness in Danish dairy cows: frequency and possible risk factors. Prev. Vet. Med. 22:213-225. https://doi.org/10.1016/0167-5877(94) 00411-B.

Andreasen, S.N., F. Wemelsfelder, P. Sandoe, and B. Forkman. 2013. The correlation of qualitative behavior assessments with Welfare Quality ${ }^{\circledR}$ protocol outcomes in on-farm welfare assessment of dairy cattle. Appl. Anim. Beh. Sci. 143:9-17. https://doi.org/10.1016/j.applanim.2012.11.013.

Andreasen, S.N., P. Sandoe, and B. Forkman. 2014. Can animal-based welfare assessment be simplified? A comparison of the Welfare Quality ${ }^{\circledR}$ protocol 
for dairy cattle and the simpler and less time-consuming protocol developed by the Danish Cattle Federation. Anim. Welf. 23:81-94. https://doi. org/10.7120/09627286.23.1.081.

Archer, S.C., F. Mc Coy, W. Wapenaar, and M.J. Green. 2013. Association of season and herd size with somatic cell count for cows in Irish, English, and Welsh dairy herds. Vet. J. 196:515-521. https://dx.doi.org/10.1016/j.tvjl. 2012.12.004.

Barkema, H.W., M.A.G. von Keyserlingk, J.P. Kastelic, T.J.G.M. Lam, C. Luby, J.-P. Roy, S.J. LeBlanc, G.P. Keefe, and D.F. Kelton. 2015. Invited review: Changes in the dairy industry affecting dairy cattle health and welfare. J. Dairy Sci. 98:7426-7445. https://doi.org/10.3168/jds.2015-9377.

Barkema, H.W., Y.H. Schukken, T.J.G.M. Lam, M.L. Beiboer, G. Benedictus, and A. Brand. 1999. Management practices associated with the incidence rate on clinical mastitis. J. Dairy Sci. 82:1643-1654. https://doi.org/10.3168/jds. S0022-0302(99)75393-2.

Barker, Z.E., K.A. Leach, H.R. Whay, N.J. Bell, and D.C.J. Main. 2010. Assessment of lameness prevalence and associated risk factors in dairy herds in England and Wales. J. Dairy Sci. 93: 932-941. https://doi.org/10. 3168/jds.2009-2309.

Benatallah, A., F. Ghozlane, and M. Marie. 2015. Dairy cow welfare assessment on Algerian farms. Afr. J. Agric. Res. 10:895-901. https://doi.org/10.5897/ AJAR2015.9483.

Berry, D.P., R.F. Veerkamp, and P. Dillon. 2006. Phenotypic profiles for body weight, body condition score, energy intake, and energy balance across different parities and concentrate feeding levels. Livest. Sci. 104:1-12. https://doi.org/10.1016/..livsci.2006.02.012.

Bewley, J.M., and M.M. Schutz. 2008. Review: an interdisciplinary review of body condition scoring for dairy cattle. Prof. Anim. Sci. 24:507-529. https:// doi.org/10.15232/S1080-7446(15)30901-3.

Black, R.A., R.J. Grant, and P.D. Krawczel. 2016. Short communication: Shortterm changes in stocking density did not alter meal characteristics of lactating Holstein dairy cattle. J. Dairy Sci. 99:6572-6577. https://doi.org/10. 3168/jds.2015-9602.

Bokkers E.A.M., M. de Vries, I.C.M.A. Antonissen, and I.J.M. de Boer. 2012. Inter- and intra-observer reliability of experienced and inexperienced observers for the Qualitative Behaviour Assessment in dairy cattle. Anim. Welf. 21:307-318. https://doi.org/10.7120/09627286.21.3.307. 
Brenninkmeyer, C., S. Dippel, J. Brinkmann, S. March, C. Winckler, and U. Knierim, 2013. Hock lesion epidemiology in cubicle housed dairy cows across two breeds, farming systems and countries. Prev. Vet. Med. 109:236-245. https://doi.org/10.1016/.jprevetmed.2012.10.014.

Brscic, M., F. Wemelsfelder, E. Tessitore, F. Gottardo, G. Cozzi, and C.G. van Reenen. 2009. Welfare assessment: correlations and integration between a qualitative behavioural assessment and a clinical/health protocol applied in veal calves farms. Ital. J. Anim. Sci. 8:601-603. https://doi.org/10.4081/ ijas.2009.s2.601.

Chapinal, N., A.K. Barrientos, M.A.G. von Keyserlingk, E. Galo, and D.M. Weary. 2013. Herd-level risk factors for lameness in freestall farms in the northeastern United States and California. J. Dairy Sci. 96:318-328. https:// doi.org/10.3168/jds.2012-5940.

Chebel, R.C., P.R.B. Silva, M.I. Endres, M.A. Ballou, and K.L. Luchterland. 2016. Social stressors and their effects on immunity and health of periparturient dairy cows. J. Dairy Sci. 99:3217-3228. https://doi.org/10.3168/jds.201510369.

Coignard, M., R. Guatteo, I. Veissier, A. de Boyer des Roches, L. Mounier, A. Lehébel, and N. Bareille. 2013. Description and factors of variation of the overall health score in French dairy cattle herds using the Welfare Quality ${ }^{\circledR}$ Assessment protocol. Prev. Vet. Med. 112:296-308. https://doi.org/10. 1016/i.prevetmed.2013.07.018.

Collings, L.K.M., D.M. Weary, N. Chapinal, and M.A.G. von Keyserlingk. 2011. Temporal feed restriction and overstocking increase competition for feed by dairy cattle. J. Dairy Sci. 94: 5480-5486. https://doi.org/10.3168/jds. 2011-4370.

Cook, N.B., J.P. Hess, M.R. Foy, T.B. Bennett, and R.L. Brotzman. 2016. Management characteristics, lameness, and body injuries of dairy cattle housed in high-performance dairy herds in Wisconsin. J. Dairy Sci. 99:5879-5891. https://doi.org/10.3168/jds.2016-10956.

De Boyer des Roches, A., I. Veissier, M. Coignard, N. Bareille, R. Guatteo, J. Capdeville, E. Gilot-Fromont, and L. Monier. 2014. The major welfare problems of dairy cows in French commercial farms: an epidemiological approach. Anim. Welf. 23:467-478. https://doi.org/10.7120/09627286.23. 4.467.

De Graaf, S., B. Ampe, and F.A.M. Tuyttens. 2017a. Assessing dairy cow welfare at the beginning and end of the indoor period using the Welfare Quality ${ }^{\circledR}$ protocol. Anim. Welf. 26: 213-221. https://doi.org/10.7120/09627286.26. $\underline{2.213 .}$ 
De Graaf, S., B. Ampe, C. Winckler, M. Radeski, L. Mounier, M.K. Kirchner, M.J. Haskell, F.J.C.M. van Eerdenburg, A. de Boyer des Roches, S.N. Andreasen, J. Bijttebier, L. Lauwers, W. Verbeke, and F.A.M. Tuyttens. 2017b. Trained-user opinion about Welfare Quality measures and integrated scoring of dairy cattle welfare. J. Dairy Sci. 100:6376-6388. https://doi.org/ 10.3168/jds.2016-12255.

De Graaf, S., B. Ampe, S. Buijs, S.N. Andreasen, A. De Boyer des Roches, F.J.C.M. van Eerdenburg, M.J. Haskell, M.K. Kirchner, L. Mounier, M. Radeski, C. Winckler, J. Bijttebier, L. Lauwers, W. Verbeke, and F.A.M. Tuyttens. 2018. Sensitivity of the integrated Welfare Quality ${ }^{\circledR}$ scores to changing values of individual dairy cattle welfare measures. Anim. Welf. 27:157-166. https://doi.org/10.7120/09627286.27.2.157.

De Vries, M., E.A.M. Bokkers, C.G. van Reenen, B. Engel, G. van Schaik, T. Dijkstra, and I.J.M. de Boer. 2015. Housing and management factors associated with indicators of dairy cattle welfare. Prev. Vet. Med. 118:80-92. https://doi.org/10.1016/j.prevetmed. 2014.11.016.

De Vries, M., E.A.M. Bokkers, G. van Schaik, B. Engel, T. Dijkstra, and I.J.M. de Boer. 2016. Improving the time efficiency of identifying dairy herds with poorer welfare in a population. J. Dairy Sci. 99:8282-8296. http://dx.doi. org/10.3168/jds.2015-9979.

De Vries, M., E.A.M. Bokkers, G. van Schaik, B. Engel, T. Dijkstra, and J.M. de Boer. 2014. Exploring the value of routinely collected herd data for estimating dairy cattle welfare. J. Dairy Sci. 97:715-730. http://dx.doi.org/ 10.3168/jds.2013-6585.

De Vries, M., E.A.M. Bokkers, G. van Schaik, R. Botreau, B. Engel, T. Dijkstra, and I.J.M. de Boer. 2013. Evaluating results of the Welfare Quality multicriteria evaluation model for classification of dairy cattle welfare at the herd level. J. Dairy Sci. 96:6264-6273. http://dx.doi.org/10.3168/jds.2012-6129.

Destatis. 2011. Land- und Forstwirtschaft, Fischerei Rinder- und Schweinebestand Statistisches Bundesamt. Fachserie 3 Reihe 4.1. https://www. destatis.de/GPStatistik/servlets/MCRFileNodeServlet/DEHeft_derivate_ 00004135/2030213109004.pdf (Accessed 07. October 2017).

Destatis. 2017. Land- und Forstwirtschaft, Fischerei Rinder- und Schweinebestand Statistisches Bundesamt. Fachserie 3 Reihe 4.1. https://www. destatis.de/GPStatistik/servlets/MCRFileNodeServlet/DEHeft_derivate_ 00032776/2030213169004.pdf (Accessed 07. October 2017).

DeVries, T.J., M.A.G. von Keyserlingk, and K.A. Beauchemin. 2005. Frequency of feed delivery affects the behavior of lactating dairy cows. J. Dairy. Sci. 88:3553-3562. https://doi.org/10.3168/jds.S0022-0302(05)73040-X. 
Dippel, S., M. Dolezal, C. Brenninkmeyer, J. Brinkmann, S. March, U. Knierim, and C. Winckler. 2009. Risk factors for lameness in cubicle housed Austrian Simmental dairy cows. Prev. Vet. Med. 90:102-112. http://dx.doi.org/ 10.1016/i.prevetmed.2009.03.014.

Doherr, M.G., M. Roesch, W. Schaeren, M. Schallibaum, and J.W. Blum. 2007. Risk factors associated with subclinical mastitis in dairy cows on Swiss organic and conventional production system farms. Vet. Med. 52:487-495. https://doi.org/10.17221/2060-VETMED.

Dohmen, W., F. Neijenhuis, and H. Hogeveen. 2010. Relationship between udder health and hygiene on farms with an automatic milking system. J. Dairy Sci. 93:4019-4033. https://doi.org/10.3168/jds.2009-3028.

Espejo, L.A., and M.I. Endres. 2007. Herd-level risk factors for lameness in highproducing Holstein cows housed in freestall barns. J. Dairy Sci. 90:306314. https://doi.org/10.3168/jds.S0022-0302(07)72631-0.

Estevez, I., I.L. Andersen, and E. Naevdal. 2007. Group size, density and social dynamics in farm animals. Appl. Anim. Beh. Sci. 103:185-204. https://doi. org/10.1016/..applanim.2006.05.025.

Fabian, J., R.A. Laven, and H.R. Whay. 2014. The prevalence of lameness on New Zealand dairy farms: A comparism of farmer estimate and locomotion scoring. The Vet. J. 201:31-38. http://dx.doi.org/10.1016/.tvil.2014.05. 011.

Falk, A.C., D.M. Weary, C. Winckler, and M.A.G. von Keyserlingk. 2012. Preference for pasture versus freestall housing by dairy cattle when stall availability indoors is reduced. J. Dairy Sci. 95, 6409-6415. https://doi.org/ 10.3168/jds.2011-5208.

Fregonesi, J.A., and J.D. Leaver. 2002. Influence of space allowance and milk yield level on behavior, performance and health of dairy cows housed in strawyard and cubicle systems. Livest. Prod. Sci. 78:245-257. https://doi. org/ 10.1016/S0301-6226(02)00097-0.

Fregonesi, J.A., C.B. Tucker, and D.M. Weary. 2007. Overstocking reduces lying time in dairy cows. J. Dairy Sci. 90:3349-3354. https://doi.org/10.3168 jids.2006-794.

Grant, R.J., and J.L. Albright. 2001. Effect of animal grouping on feeding behavior and intake of dairy cattle. J. Dairy Sci. 84:156-163. https://doi. org/10.3168/jds.S0022-0302(01)70210-X.

Haskell, M.J., L.J. Rennie, V.A. Bowell, M.J. Bell, and A.B. Lawrence. 2006. Housing system, milk production, and zero-grazing effects on lameness 
and leg injury in dairy cows. J. Dairy Sci. 89:4259-4266. https://doi.org/ 10.3168/jds.S0022-0302(06)72472-9.

Heath, C.A.E., W.J. Browne, S. Mullan, and D.C.J. Main. 2014b. Navigating the iceberg: reducing the number of parameters within the Welfare Quality ${ }^{\circledR}$ Assessment protocol for dairy cows. Animal. 8:1978-1986. https://doi.org/ 10.1017/S1751731114002018.

Heath, C.A.E., Y. Lin, S. Mullan, W.J. Browne, and D.C.J. Main. 2014a. Implementing Welfare Quality ${ }^{\circledR}$ in UK assurance schemes: evaluating the challenges. Anim. Welf. 23: 95-107. https://doi.org/10.7120/09627286.23.1.0 $\underline{95}$.

Hill, C.T., P.D. Krawczel, H.M. Mann, C.S. Ballard, R.C. Hovey, W.A. Falls, and R.J. Grant. 2009. Effect of stocking density on the short-term behavioural responses of dairy cows. Appl. Anim. Beh. Sci. 117:144-149. https://doi. org/10.1016/..applanim.2008.12.012.

Hosseinkhani, A., T.J. DeVries, K.L. Proudfoot, R. Valizadeh, D.M. Veira, and M.A.G. von Keyserlingk. 2008. The effects of feed bunk competition on the feed sorting behavior of close-up dry cows. J. Dairy Sci. 91:1115-1121. https://doi.org/10.3168/jds.2007-0679.

Hovinen, M., and S. Pyörälä. 2011. Invited review: Udder health of dairy cows in automatic milking. J. Dairy Sci. 94:547-562. https://doi.org/10.3168/jds. 2010-3556.

Huzzey, J.M., T.J. DeVries, P. Valois, and M.A.G. von Keyserlingk. 2006. Stocking density and feed barrier design affect the feeding and social behavior of dairy cattle. J. Dairy Sci. 89, 126-133. https://doi.org/10.3168/jds.S00220302(06)72075-6.

Ingham, S.C., Y. Hu, and C. Ané. 2011. Comparison of bulk-tank standard plate count and somatic cell count for Wisconsin dairy farms in three size categories. J. Dairy Sci. 94:4237-4241. https://doi.org/10.3168/jds.2011-4310.

Ito, K., N. Chapinal, D.M. Weary, and von M.A.G. Keyserlingk. 2014. Associations between herd-level factors and lying behavior of freestall-housed dairy cows. J. Dairy Sci. 97:2081-2089. https://doi.org/10.3168/jds.2013-6861.

Ivemeyer, S., U. Knierim, and S. Waiblinger. 2011. Effect of human-animal relationship and management on udder health in Swiss dairy herds. J. Dairy Sci. 94: 5890-5902. https://doi.org/10.3168/jds.2010-4048.

Jacobs, J.A., and J.M. Siegford. Invited review: The impact of automatic milking systems on dairy cow management, behavior, health, and welfare. J. Dairy Sci. 95:2227-2247. https://doi.org/10.3168/jds.2011-4943. 
Kester, E., M. Holzhauer, and K. Frankena. 2014. A descriptive review of the prevalence and risk factors of hock lesions in dairy cows. Vet. J. 202: 222228. https://doi.org/10.1016/.j.tvil.2014.07.004.

Kielland, C., L.E. Ruud, A.J. Zanella, and O. Osteras. 2009. Prevalence and risk factors for skin lesions on legs of dairy cattle housed in freestalls in Norway. J. Dairy Sci. 92:5487-5496. https://doi.org/10.3168/jds.2009-2293.

Krawczel, P.D., L.B. Klaiber, R.E. Butzler, L.M. Klaiber, H.M. Dann, C.S. Mooney, and R.J. Grant. 2012b. Short-term increases in stocking density affect the lying and social behavior, but not the productivity, of lactating Holstein dairy cows. J. Dairy Sci. 95:4298-4308. https://doi.org/10.3168/jds.20114687.

Krawczel, P.D., L.B. Klaiber, R.E. Butzler, L.M. Klaiber, H.M. Dann, C.S. Mooney, and R.J. Grant. 2012b. Short-term increases in stocking density affect the lying and social behavior, but not the productivity, of lactating Holstein dairy cows. J. Dairy Sci. 95:4298-4308. https://doi.org/10.3168/jds.20114687.

Lievaart, J.J., H.W. Barkema, W.D.J. Kremer, J. van den Broek, J.H.M. Verheijden, and J.A.P. Heesterbeek. 2007. Effect of herd characteristics, management practices, and season on different categories of the herd somatic cell count. J. Dairy Sci. 90:4137-4144. https://doi.org/10.3168/jds. 2006-847.

Lombard, J.E., C.B. Tucker, M.A.G. von Keyserlingk, C.A. Kopral and D.M. Weary. 2010. Associations between cow hygiene, hock injuries, and free stall usage on US dairy farms. J. Dairy Sci. 93, 4668-4676. https://doi.org/ 10.3168/jds.2010-3225.

Napolitano, F., U. Knierim, F. Grasso, and G. de Rosa. Positive indicators of cattle welfare and their applicability to on-farm protocols. Ital. J. Anim. Sci. 8:355-365. https://doi.org/10.4081/ijas.2009.s1.355.

Nash, C.G.R., D.F. Kelton, T.J. DeVries, E. Vasseur, J. Coe, J.C. Zaffino Heyerhoff, V. Bouffard, D. Pellerin, J. Rushen, A.M. de Passillé, and D.B. Haley. 2016. Prevalence of and risk factors for hock and knee injuries on dairy cows in tiestall housing in Canada. J. Dairy Sci. 99:6494-6506. https:// doi.org/10.3168/jds.2015-10676.

Nyman, A.-K., T. Ekman, U. Emanuelson, A.H. Gustafsson, K. Holtenius, K. Persson Waller, and C. Hallén Sandgren. 2007. Risk factors associated with the incidence of veterinary-treated clinical mastitis in Swedish dairy herds with a high milk yield and a low prevalence of subclinical mastitis. Prev. Vet. Med. 78:142-160. https://doi.org/10.1016/..prevetmed.2006. $\underline{10.002 .}$ 
Oleggini, G.H., L.O. Ely, and J.W. Smith. 2001. Effect of region and herd size on dairy herd performance parameters. J. Dairy Sci. 84:1044-1050. https:// doi.org/10.3168/jds.S0022 -0302(01)74564-X.

Petherick, J.C., and C.J.C. Phillips. 2009. Space allowances for confined livestock and their determination from allometric principles. Appl. Anim. Beh. Sci. 117:1-12. https://doi.org/10.1016/10.1016/j.applanim.2008.09.008.

Phytian, C., E. Michalopoulou, J. Duncan, and F. Wemelsfelder. 2013. Inter-observer reliability of qualitative behavioural assessments of sheep. Appl. Anim. Beh. Sci. 144:73-79. https://doi.org/10.1016/..applanim.2012.11. $\underline{011 .}$

Plesch, G., N. Broerkens, S. Laister, C. Winckler, and U. Knierim. 2010. Reliability and feasibility of selected measures concerning resting behaviour for the on-farm welfare assessment in dairy cows. Appl. Anim. Beh. Sci. 126:1926. https://doi.org/10.1016/i.applanim.2010.05.003.

Popescu, S., C. Borda, E.A. Diugan, M. Niculae, R. Stefan, and C.D. Sandru. 2014. The effect of the housing system on the welfare quality of dairy cows. Ital. J. Anim. Sci. 13:2940. https://doi.org/10.4081/ijas.2014.2940.

Popescu, S., C. Borda, E.A. Diugan, M. Spinu, I.S. Groza, and C.D. Sandru. 2013. Dairy cows welfare quality in tie-stall housing system with or without access to exercise. Acta Vet. Scand. 55: 43-54. https://doi.org/10.1186/ 1751-0147-55-43.

Potterton, S.L., M.J. Green, J. Harris, K.M. Millar, H.R. Whay, and J.N. Huxley. 2011. Risk factors associated with hair loss, ulceration, and swelling at the hock in freestall-housed UK dairy herds. J. Dairy Sci. 94:2952-2963. https://doi.org/10.3168/jds.2010-4084.

Proudfoot, K., and G. Habing. 2015. Social stress as a cause of diseases in farm animals: Current knowledge and future directions. Vet. J. 206:15-21. https://doi.org/10.1016/j.tvil.2015.05.024.

Roche, J.R., N.C. Friggens, J.K. Kay, M.W. Fisher, K.J. Stafford, and D.P. Berry. 2009. Invited review: Body condition score and its association with dairy cow productivity, health, and welfare. J. Dairy Sci. 92:5769-5801. https:// doi.org/10.3168/jds.2009-2431.

Rousing, T., and F. Wemelsfelder. 2006. Qualitative assessment of social behavior of dairy cows housed in loose housing systems. Appl. Anim. Beh. Sci. 101:40-53. https://doi.org/10.1016/..applanim.2005.12.009.

Sandoe, P., B. Forkman, F. Hakansson, S.N. Andreasen, R. Nohr, M. Denwood, and T.B. Lund. 2017. Should the contribution of one additional lame cow 
depend on how many other cows on the farm are lame? Animals. 7:96108. https://doi.org/10.3390/ani7120096.

Schewe, R.L., J. Kayitsinga, G.A. Contreras, C. Odom, W.A. Coats, P. Durst, E.P. Hovingh, R.O. Martinez, R. Mobley, S. Moore, and R.J. Erskine. 2015. Herd management and social variables associated with bulk tank somatic cell count in dairy herds in the eastern United States. J. Dairy Sci. 98:76507665. https://doi.org/10.3168/jds.2014-8840.

Smith, J.W., L.O. Ely, W.M. Graves, and W.D. Gilson. 2002. Effect of milking frequency on DHI performance measures. J. Dairy Sci. 85:3526-3533. https://doi.org/10.3168/jds.S0022-0302(02)74442-1.

Solano, L., H. W. Barkema, E. A. Pajor, S. Mason, S. J. LeBlanc, J. C. Zaffino Heyerhoff, C. G. R. Nash, D. B. Haley, E. Vasseur, D. Pellerin, J. Rushen, A. M. de Passillé, and K. Orsel. 2015. Prevalence of lameness and associated risk factors in Canadian Holstein-Friesian cows housed in freestall barns. J. Dairy Sci. 98:6978-6991. https://doi.org/10. 3168/jds.2015-9652.

Sova, A.D., S.J. LeBlanc, B.W. McBride, and T.J. DeVries. 2013. Associations between herd-level feeding management practices, feed sorting, and milk production in freestall dairy farms. J. Dairy Sci. 96:4759-4770. https://doi. org/10.3168/ids.2013-6679.

Spinka, M. 2006. How important is natural behavior in animal farming systems? Appl. Anim. Beh. Sci. 100:117-128. https://doi.org/10.1016/j.applanim. 2006.04.006.

Stankovic, B., S. Hristov, D. Ostojic-Andric, Z. Zlatanovic, Lj. Samalovac, and N. Maksimovic. 2014. The most common health disorders and welfare of dairy cows and calves. Biotech. Anim. Husb. 30:549-560. https://doi.org 10.2298/BAH1404549S.

Tremetsberger, L., C. Leeb, and C. Winckler. 2015. Animal health and welfare planning improves udder health and cleanliness but not leg health in Austrian dairy herds. J. Dairy Sci. 98:6801-6811. http://dx.doi.org/10. 3168/jds.2014-9084.

Val-Laillet, D., D.M. Veira, and M.A.G. von Keyserlingk. 2008. Short communication: Dominance in free-stall-housed dairy cattle is dependent upon resource. J. Dairy Sci. 91:3922-3926. https://doi.org/10.3168/jds.2008-1332.

Van Os, J.M.C., C. Winckler, J. Trieb, S.V. Matarazzo, T.W. Lehenbauer, J.D. Champagne, and C.B. Tucker. 2018. Reliability of sampling strategies for measuring dairy cattle welfare on commercial farms. J. Dairy Sci. 101:1495-1504. https://doi.org/ 10.3168/jds.2017-13611. 
Veissier, I., J. Capdeville, and E. Delval. 2004. Cubicle housing systems for cattle: Comfort of dairy cows depends on cubicle adjustment. J. Anim. Sci. 82:3321-3337. https://doi.org/ 10.2527/2004.82113321x.

Von Keyserlingk, M.A.G., A. Barrientos, K. Ito, E. Galo, and D.M. Weary. 2012. Benchmarking cow comfort on North American freestall dairies: Lameness, leg injuries, lying time, facility design, and management for high-producing Holstein dairy cows. J. Dairy Sci. 95:7399-7408. https://doi.org /10.3168/ jds.2012-5807.

Webster, A.J.F. 2001. Effects of housing and two forage diets on the development of claw horn lesions in dairy cows at first calving and in first lactation. Vet. J. 162, 56-65. https://doi.org/10.1053/tvil.2001.0569.

Wechsler, B., J. Schaub, K. Friedli, and R. Hauser. 2000. Behaviour and leg injuries in dairy cows kept in cubicle systems with straw bedding or soft lying mats. Appl. Anim. Beh. Sci. 69:189-197. https://doi.org/10.1016/S01681591(00)00134-9.

Welfare Quality. 2012. Welfare Quality ${ }^{\circledR}$ Assessment protocol for cattle. Welfare Quality ${ }^{\circledR}$ Consortium, Lelystad, Netherlands. www.welfarequalitynetwork. net/network/45848/7/0/40 (Accessed 21. August 2017).

Wemelsfelder, F. 2007. How animals communicate quality of life: the qualitative assessment of behavior. Anim. Welf. 16:25-31. ISSN 0962-7286.

Wemelsfelder, F., T.E.A. Hunter, M.T. Mendl, and A.B. Lawrence. 2001. Assessing the whole animal: a free choice profiling approach. Anim. Beh. 62:209-220. https://doi.org/10.1006/anbe.2001.1741.

Winckler, C., C.B. Tucker, and D. Weary. 2015. Effects of under- and overstocking freestalls on dairy cattle behavior. Appl. Anim. Beh. Sci. 170, 14-19. https://doi.org/10.1016/i.applanim.2015.06.003.

Wissenschaftlicher Beirat Agrarpolitik beim BMEL (WBA). 2015. Wege zu einer gesellschaftlich akzeptierten Nutztierhaltung. Gutachten. Berlin.

Zaffino Heyerhoff, J.C., S.J. LeBlanc, T.J. DeVries, C.G.R. Nash, J. Gibbons, K. Orsel, H.W. Barkema, L. Solano, J. Rushen, A.M. de Passillé, and D.B. Haley. 2014. Prevalence of and factors associated with hock, knee, and neck injuries on dairy cows in freestall housing in Canada. J. Dairy Sci. 97:173-184. https://dx.doi.org/10.3168/jds.2012-6367.

Zuliani, A., A. Romanzin, M. Corazzin, S. Salvador, J.C. Abrahantes, and S. Bovolenta. 2017. Welfare assessment in traditional mountain dairy farms: above and beyond resource-based measures. Anim. Welf. 26: 203-211. https://doi.org/10.7120/09627286.26.2.203. 


\section{KAPITEL 7}

Schlussfolgerungen 


\section{Kapitel $7 \quad$ Schlussfolgerungen}

Ziel des Promotionsvorhabens war es potentielle Einflüsse von verschiedenen Haltungs- und Managementfaktoren auf das Tierwohlniveau zu identifizieren. Dabei sollten der Zusammenhang zwischen den im Fokus der gesellschaftlichen Diskussion stehenden Faktoren „Bestandsgröße“ und „Bestandsdichte“ und dem Tierwohlniveau auf Betriebsebene untersucht sowie ein neuartiger Benchmarking-Ansatz angewendet werden, um Risikofaktoren für das Tierwohlniveau von Milchkühen ableiten zu können.

Die Ergebnisse der ersten Studie weisen nicht auf einen linearen Zusammenhang zwischen der Bestandsgröße und dem generellen Tierwohlniveau hin. Zwar waren einzelne Tierwohlindikatoren (magere Kühe, Troglänge, Abliegezeit, Verschmutzung der Unterbeine und Vertreibungen) mit der Bestandsgröße assoziiert, jedoch waren die Resultate keineswegs konsistent. Einige Tierwohlindikatoren waren in größeren Betrieben besser, während andere in kleineren Betrieben auf ein höheres Tierwohlniveau hindeuteten. Zusammenfassend lässt sich festhalten, dass die Bestandsgröße kein geeigneter Indikator für das betriebsindividuelle Tierwohlniveau ist und eine Diskussion über von der Politik festgelegte Bestandsobergrenzen zumindestens aus Tierwohlperspektive fraglich ist. Dennoch weist die Variabilität der Ergebnisse in jeder der vier Bestandsgrößenklassen auf ein großes Potential zur Verbesserung des Tierwohlniveaus hin. In Abhängigkeit ihrer Bestandsgröße und den damit verbundenen Ressourcen könnten die Betriebe verschiedene Maßnahmen zur Förderung des Tierwohls anwenden. Hierfür sind jedoch weitere Forschungen zum Einfluss der verschiedenen Haltungs- und Managementfaktoren auf das Tierwohlniveau notwendig.

Die Ergebnisse der zweiten Studie belegen auch keinen konsistenten Zusammenhang zwischen der Bestandsdichte und dem Tierwohlniveau in der Milchviehhaltung. Demzufolge stellt die Bestandsdichte allein keinen hinreichenden Indikator für das TierwohIniveau auf Betriebsebene dar. Einige Tierwohlindikatoren wiesen bessere Resultate in Betrieben mit höherer Bestandsdichte auf, während in anderen Tierwohlindikatoren Betriebe mit niedrigerer Bestandsdichte bes- 
sere Ergebnisse erzielten. Zudem unterschieden sich die gefundenen Zusammenhänge zwischen den Parametern der Bestandsdichte Tier-Liegeboxen-Verhältnis (schwere Lahmheit), Tier-Fressplatz-Verhältnis (Nasenausfluss, Kopfstöße und positive Emotionen) oder dem Verkehrsflächenangebot (Troglänge, schwere Lahmheit und Mastitisinzidenz). Aus diesem Grund sollten bei der Optimierung der Haltungsumwelt und des Managements stets alle drei genannten Parameter der Bestandsdichte gleichermaßen berücksichtigt werden. Sonst laufen die Betriebe in Gefahr wichtige Einflussfaktoren auf das Tierwohlniveau zu übersehen. Nichtsdestotrotz sollten in weiteren Untersuchungen mit größeren Datensätzen auch potentielle Wechselwirkungen zwischen den Parametern der Bestandsdichte überprüft werden, die das Tierwohlniveau der Milchkühe ebenfalls beeinflussen könnten.

Die Ergebnisse der dritten Studie deuten auf potentielle Assoziationen zwischen Haltungs- und Managementfaktoren und einzelnen Indikatoren des Welfare Quality ${ }^{\circledR}$ Protokolls in der univariablen statistischen Analyse hin. Allerdings wurden in der multivariablen logistischen Regression nur vereinzelte Effekte auf schwere Lahmheiten, Mastitisinzidenz und Sozialverhalten nachgewiesen. Die geringe Anzahl statistisch abgesicherter Zusammenhänge könnte auf die relative geringe Stichprobe und die teilweise fehlenden Angaben im Managementfragebogen zurückzuführen sein. Dadurch wurden die Anzahl der für die Analyse zur Verfügung stehenden Betriebe noch weiter reduziert. Unter Berücksichtigung dieser Limitationen, liefert der verwendete Benchmarking-Ansatz vielversprechende Ergebnisse. Der Vergleich von Betrieben mit höherem und mit niedrigerem Tierwohlstatus in Bezug auf einzelne Tierwohlindikatoren liefert nützliche Informationen über Möglichkeiten das Tierwohlniveau effektiv zu verbessern. Selbst unter den relativ ähnlichen Haltungsbedingungen in der vorliegenden Studie wurde eine große Variabilität der Ergebnisse festgestellt. Dieser Umstand spricht für einen großen Einfluss des betriebsindividuellen Managements. Nichtsdestrotrotz sollten zur Validierung der Ergebnisse weitere Studien mit größeren Datensätzen unter Berücksichtigung unterschiedlicher Betriebsformen, Haltungssysteme und Managementoptionen durchgeführt werden. Auf diese Weise könnte sich die Aussagekraft des Benchmarking-Ansatzes steigern lassen und den Landwirten somit langfristig geholfen werden das Tierwohl auf ihren Betrieben zu erhöhen. 
Zusammenfassend lässt sich feststellen, dass das Tierwohl auf Milchviehbetrieben durch viele verschiedene Haltungs- und Managementfaktoren beeinflusst werden kann. Aufgrund des multidimensionalen Charakters des Tierwohls ist eine pauschale Bewertung von Milchviehbetrieben anhand einzelner Haltungsund Managementfaktoren wie z.B. Bestandsgröße und Bestandsdichte problematisch. Den Erkenntnissen der vorliegenden Dissertation zufolge ist vielmehr eine Betrachtung des Tierwohlniveaus auf Betriebsebene erforderlich, da sich nur so die komplexen Interaktionen von Haltungsumwelt und Managementpraxis annähernd abbilden lassen. Haltung und Management beeinflussen sich gegenseitig und eine isolierte Betrachtung einzelner Faktoren erlaubt daher keinen unmittelbaren Rückschluss auf das tatsächliche Tierwohlniveau im Betrieb. Die Ergebnisse der Tierwohlbewertungen mit Hilfe des Welfare Quality ${ }^{\circledR}$ Protokolls für Rinder unterscheiden sich sehr deutlich zwischen den Betrieben, so dass von einem erheblichen innerbetrieblichen Potential zur Verbesserung des Tierwohls ausgegangen werden kann. Dabei könnte der im Rahmen des Promotionsvorhabens getestete Benchmarking-Ansatz einen wichtigen Beitrag zur Optimierung der Haltungsumwelt und der Managementpraxis leisten. Zum einen liefert dieses Verfahren wichtige Informationen zu potentiellen Erfolgsfaktoren aus den Bereichen Haltung und Management und zum anderen könnte durch den praxisnahen Vergleich mit anderen Milchviehbetrieben die Motivation zur Investition in erfolgsversprechende Tierwohlverbesserungsmaßnahmen erhöht werden. Durch die Gestaltung der Haltungsumwelt und ihr Betriebsmanagement haben MilchviehhalterInnen zahlreiche Möglichkeiten das Tierwohlniveau zu erhöhen. Zu diesem Zweck sollten den LandwirtInnen jedoch von Seiten der Wissenschaft, Beratung und Politik geeignete, flankierende Maßnahmen zur Verfügung gestellt werden, um sie bei dem Optimierungsprozess tatkräftig zu unterstützen. Nur so lässt sich das Tierwohlniveau auf Milchviehbetrieben nachhaltig verbessern. 
Literaturverzeichnis 


\section{Literaturverzeichnis}

Adams, A.E., J.E. Lombard, C.P. Fossler, I.N. Román-Muñiz, and C.A. Kopral. 2017. Associations between housing and management practices and the prevalence of lameness, hock lesions, and thin cows on US dairy operations. J. Dairy Sci. 100:2119-2136. https://doi.org/10.3168/jds.201611517.

Aerts, S., D. Lips, S. Spencer, E. Decuypere, and J. de Tavenier. 2006. A new framework for the assessment of animal welfare: Integrating existing knowledge from a practical ethics perspective. J. Agric. Environ. Ethics 19:67-76. https://doi.org/10.1007/s10806-005-4376-y.

Alban, L. 1995. Lameness in Danish dairy cows: frequency and possible risk factors. Prev. Vet. Med. 22:213-225. https://doi.org/10.1016/0167-5877(94) 00411-B.

Andreasen, S.N., F. Wemelsfelder, P. Sandoe, and B. Forkman. 2013. The correlation of qualitative behavior assessments with Welfare Quality ${ }^{\circledR}$ protocol outcomes in on-farm welfare assessment of dairy cattle. Appl. Anim. Beh. Sci. 143:9-17.https://doi.org/10.1016/..applanim.2012.11.013.

Andreasen, S.N., P. Sandoe, and B. Forkman. 2014. Can animal-based welfare assessment be simplified? A comparison of the Welfare Quality ${ }^{\circledR}$ protocol for dairy cattle and the simpler and less time-consuming protocol developed by the Danish Cattle Federation. Anim. Welf. 23:81-94. https://doi. org/10.7120/09627286.23.1.081.

Arbeitsgemeinschaft Deutscher Rinderzüchter (ADR). 2008. Jahresbericht 2008 - Das Wichtigste in Kürze. ADR.de. (Accessed 07. October 2017).

Arbeitsgemeinschaft Deutscher Rinderzüchter (ADR). 2016. Jahresbericht 2016 - Das Wichtigste in Kürze. ADR.de (Accessed 07. October 2017).

Archer, S.C., F. Mc Coy, W. Wapenaar, and M.J. Green. 2013. Association of season and herd size with somatic cell count for cows in Irish, English, and Welsh dairy herds. Vet. J. 196:515-521. http://dx.doi.org/10.1016/j.tvjl.20 12.12.004.

Armbrecht, L., C. Lambertz, D. Albers, and M. Gauly. 2018. Does access to pasture affect claw condition and health in dairy cows? Vet. Rec. 182:79-89. https://doi.org/10.1136/vr.104554.

Arnott, G., C.P. Ferris, and N.E. O'Connell. 2016. Review: welfare of dairy cows in continuously housed and pasture-based production systems. Animal. 11:261-273. https://doi.org/10.1017/S1751731116001336. 
Barkema, H.W., M.A.G. von Keyserlingk, J.P. Kastelic, T.J.G.M. Lam, C. Luby, J.-P. Roy, S.J. LeBlanc, G.P. Keefe, and D.F. Kelton. 2015. Invited review: Changes in the dairy industry affecting dairy cattle health and welfare. J. Dairy Sci. 98:7426-7445. https://doi.org/10.3168/jds.2015-9377.

Barkema, H.W., Y.H. Schukken, T.J.G.M. Lam, M.L. Beiboer, G. Benedictus, and A. Brand. 1999. Management practices associated with the incidence rate on clinical mastitis. J. Dairy Sci. 82:1643-1654. https://doi.org/10.3168/jds. S0022-0302(99)75393-2.

Barker, Z.E., K.A. Leach, H.R. Whay, N.J. Bell, and D.C.J. Main. 2010. Assessment of lameness prevalence and associated risk factors in dairy herds in England and Wales. J. Dairy Sci. 93: 932-941. https://doi.org/10.3168/ jds.2009-2309.

Barnouin, J., S. Bord, S. Bazin, and M. Chassagne. 2005. Dairy Management Practices Associated with Incidence Rate of Clinical Mastitis in Low Somatic Cell Score Herds in France. J. Dairy Sci. 88:3700-3709. https:// doi.org/10.3168/jds.S0022-0302(05)73056-3.

Barrientos, A.K., N. Chapinal, D.M. Weary, E. Galo, and M.A.G. von Keyserlingk. 2013. Herd-level risk factors for hock injuries in freestall-housed dairy cows in the northeastern United States and California. J. Dairy Sci. 96:3758-3765. https://doi.org/10.3168/jds.2012-6389.

Bartussek, H. 1996. Tiergerechtheitsindex für Rinder TGI 35 L / 1996. Bayerische Anstalt für Landwirtschaft Gumpenstein. Bayerische Anstalt für Landwirtschaft-Verlag, Gumpenstein.

Battini, M., E. Andreoli, S. Barbieri, and S. Mattiello. 2011. Long-term stability of avoidance distance tests for on-farm assessment of dairy cow relationship to humans in alpine traditional husbandry systems. Appl. Anim. Beh. Sci. 135:267-270. http://dx.doi.org/doi:10.1016/j.applanim.2011.10.013.

Bauman, C.A., H.W. Barkema, J. Dubuc, G.P. Keefe, and D.F. Kelton. 2016. Identifying management and disease priorities of Canadian dairy industry stakeholders. J. Dairy. Sci. 99:1-10. https://doi.org/10.3168/jds.2016110 $\underline{57 .}$

Beggs, D.S., A.D. Fisher, E.C. Jongman, and P.H. Hemsworth. 2015. A survey of Australian dairy farmers to investigate animal welfare risks associated with increasing scale of production. J. Dairy Sci. 98:5330-5338. http://dx. doi.org/10.3168/jds.2014-9239.

Benatallah, A., F. Ghozlane, and M. Marie. 2015. Dairy cow welfare assessment on Algerian farms. Afr. J. Agric. Res. 10:895-901. https://doi.org/10.5897/ AJAR2015.9483. 
Berge, A., and G. Vertenten. 2014. A field study to determine the prevalence, dairy herd management systems, and fresh cow clinical conditions associated with ketosis in western Eurpean dairy herds. J. Dairy Sci. 97: 21452154. https://doi.org/10.3168/jds.2013-7163.

Berry, D.P., R.F. Veerkamp, and P. Dillon. 2006. Phenotypic profiles for body weight, body condition score, energy intake, and energy balance across different parities and concentrate feeding levels. Livest. Sci. 104:1-12. https://doi.org/10.1016/j.livsci.2006.02.012.

Bewley, J.M., and M.M. Schutz. 2008. Review: an interdisciplinary review of body condition scoring for dairy cattle. Prof. Anim. Sci. 24:507-529. https:// doi.org/10.15232/S1080-7446(15)30901-3.

Bicalho, R.C., and G. Oikonomou. 2013. Control and prevention of lameness associated with claw lesions in dairy cows. Livest. Sci. 156: 96-105. https:// doi.org/10.1016/j.livsci.2013.06.007.

Black, R.A., R.J. Grant, and P.D. Krawczel. 2016. Short communication: Shortterm changes in stocking density did not alter meal characteristics of lactating Holstein dairy cattle. J. Dairy Sci. 99:6572-6577. https://doi.org/ 10.3168/jds.2015-9602.

Blokhuis, H.-J. 2008. International cooperation in animal welfare - The Welfare Quality ${ }^{\circledR}$ Project. Act. Vet. Scand. 50:10-15. https://doi.org/10.1186/17510147-50-S1-S10.

BMEL. 2017. Entwicklung der Milchleistung je Kuh. Bundesministerium für Ernährung und Landwirtschaft. https://www.bmel-statistik.de/fileadmin/user_upload/monatsberichte/SJG-9310060-0000.pdf. (Zuletzt geprüft am: 15.12.2017).

Boe, K.E., and G. Faerevik. 2003. Grouping and social preferences in calves, heifers and cows. Appl. Anim. Beh. Sci. 80:175-190. https://doi.org/10.10 16/S0168-1591(02)00217-4.

Bokkers, E.A.M., M. de Vries, I.C.M.A. Antonissen, and I.J.M. de Boer. 2012. Inter- and intra-observer reliability of experienced and inexperienced observers for the Qualitative Behaviour Assessment in dairy cattle. Anim. Welf. 21:307-318. https://doi.org/10.7120/09627286.21.3.307.

Boogard, B.K., B. Bock, S.J. Oosting, J.S.C. Wiskerke, and A.J. van der Zijpp. 2011. Social acceptance of dairy farming: The ambivalence between the two faces of modernity. J. Agric. Environ. Ethics. 24:259-282. http://dx. doi.org/10.1007/s10806-010-9256-4 
Botreau, R., M. Bonde, A. Butterworth, R. Percy, M.B.M. Bracke, J. Capdeville, and I. Veissier. 2007. Aggregation of measures to produce overall assessment of animal welfare. Part 1: A review of existing methods. Anim. Welf. 18:1179-1187. https://doi.org/10.1017/S1751731107000535.

Bradley, A.J. 2002. Bovine Mastitis: An evolving disease. The Vet. J. 164:166128. https://doi.org/https://doi.org/10.1053/tvjl.2002.0724.

Breen, J.E., M.J. Green, and A.J. Bradley. 2009. Quarter and cow risk factors associated with the occurrence of clinical mastitis in dairy cows in the United Kingdom. J. Dairy Sci. 92:2551-2561. https://doi.org/10.3168/jds. 2008-1369.

Brenninkmeyer, C., S. Dippel, J. Brinkmann, S. March, C. Winckler, and U. Knierim, 2013. Hock lesion epidemiology in cubicle housed dairy cows across two breeds, farming systems and countries. Prev. Vet. Med. 109:236-245. https://doi.org/10.1016/j.prevetmed.2012.10.014.

Brinkmann, J., H.-J. Herrmann, S. Ivemeyer, A. Pelzer und C. Winckler. 2016. Tierschutzindikatoren: Leitfaden für die Praxis - Rind. ISBN 978-3-945 088-34-0.

Broom, D. M., and A.F. Fraser. 2007. Domestic animal behaviour and welfare (4. Auflage). Centre for Agricultural Bioscience International, Wallingford.

Brscic, M., F. Wemelsfelder, E. Tessitore, F. Gottardo, G. Cozzi, and C.G. van Reenen. 2009. Welfare assessment: correlations and integration between a qualitative behavioural assessment and a clinical/health protocol applied in veal calves farms. Ital. J. Anim. Sci. 8:601-603. https://doi.org/10.4081/ ijas.2009.s2.601.

Brscic, M., H. Leruste, L.F.M. Heutinck, E.A.M. Bokkers, M. Wolthuis-Fillerup, N. Stockhofe, F. Gottardo, B.J. Lensink, G. Cozzi, ans C.G. Van Reenen. 2012. Prevalence of respiratory disorders in veal calves and potential risk factors. J. Dairy Sci. 95:2753-2764. http://dx.doi.org/10.3168/jds.20114699.

Bruijnis, M.R.N., B. Beerda, H. Hogeveen, and E.N. Stassen. 2012. Foot disorders in dairy cattle: impact on cow and dairy farmer. Anim. Welf. 21:33-40. https://doi.org/10.7120/096272812X13345905673601.

Bruun, J., A.K. Ersbøll, and L. Alban. 2002. Risk factors for metritis in Danish dairy cows. Prev. Vet. Med. 54:179-190. https://doi.org/10.1016/S01675877(02)00026-0.

Burow, E., P.T. Thomsen, T. Rousing, and J.T. Sorensen. 2013. Daily grazing time as a risk factor for alterations at the hock joint integument in dairy cows. Animal. 7:160-166. https://doi.org/10.1017/S1751731112001395. 
Butterworth, A. 2009. Animal Welfare Indicators and their use in society. In: Smulders, F. J. M. and Algers, B. (Hrsg.): Welfare of production animals. Wageningen Academic Publishers, Wageningen, 371-389.

Butterworth, A., J.A. Mench, and N. Wielebnowski. 2011. Practical Strategies to Assess (and Improve) Welfare. In: Appleby, M. C. (Hrsg.): Animal welfare (2. Auflage). Centre for Agricultural Bioscience International, Wallingford, 200-214.

Canali, E., and E. Keeling. 2009. Welfare Quality ${ }^{\circledR}$ Project - from scientific research to on farm assessment of animal welfare. Ital. J. Anim. Sci., 8:900903. https://doi.org/10.4081/ijas.2009.s2.900.

Canali, E., H.R. Whay, and K.A. Leach. 2009. Cattle health status. In: Forkman, B. and L. Keeling (eds): Assessment of Animal Welfare Measures for Dairy Cattle, Beef Bulls and Veal Calves. Welfare Quality Reports No. 11. 7788.

Capdeville, J., and I. Veissier. 2001. A method of assessing welfare in loosehoused dairy cows at farm level, focusing on animal observations. Act. Agric. Scand. A, 51:62-68. https://doi.org/10.1080/090647001316923081.

Cardoso, C.S., M.J. Hötzel, D.M. Weary, J.A. Robbins, and M.A.G. von Keyserlingk. 2016. Imagining the ideal dairy farm. J. Dairy Sci. 99:1663-1671. http://dx.doi.org/10.3168/jds.2015-9925.

Cembalo, L., F. Caracciolo, A. Lombard, T. Del Giudice, K.G. Grunert, and G. Cicia. 2016. Determinants of individual attitudes toward animal welfarefriendly food products. J. Agric. Environ. Ethics. 29:237-254. https://doi .org/10.1007/s10806-015-9598-z.

Cha, E., J.A. Hertl, D. Bar, and Y.T. Gröhn. 2010. The cost of different types of lameness in dairy cows calculated by dynamic programming. Prev. Vet. Med. 97:1-8. https://doi.org/10.1016/i.prevetmed.2010.07.011.

Chapinal, N., A.K. Barrientos, M.A.G. von Keyserlingk, E. Galo, and D.M. Weary. 2013. Herd-level risk factors for lameness in freestall farms in the northeastern United States and California. J. Dairy Sci. 96:318-328. https:// doi.org/10.3168/jds.2012-5940.

Charlton, G.L., and S.M. Rutter. 2017. The behavior of housed dairy cattle with and without pasture access: a review. Appl. Anim. Beh. Sci. 192:2-9. http://dx.doi.org/10.1016/j.applanim.2017.05.015.

Chebel, R.C., P.R.B. Silva, M.I. Endres, M.A. Ballou, and K.L. Luchterland. 2016. Social stressors and their effects on immunity and health of periparturient dairy cows. J. Dairy Sci. 99:3217-3228. https://doi.org/10.3168/jds.201510369. 
Clark, B., G.B. Stewart, L.A. Panzone, I. Kyriazakis, and L.J. Frewer. 2016. A systematic review of public attitudes, perceptions and behaviours towards production diseases associated with farm animal welfare. J. Agric. Environ. Ethics. 29: 455-478. https://doi.org/10.1007/s10806-016-9615-X.

Cochran, W. G. 1977. Sampling Techniques. 3rd ed. Wiley \& Sons, New York, NY.

Coignard, M., R. Guatteo, I. Veissier, A. de Boyer des Roches, L. Mounier, A. Lehébel, and N. Bareille. 2013. Description and factors of variation of the overall health score in French dairy cattle herds using the Welfare Quality ${ }^{\circledR}$ Assessment protocol. Prev. Vet. Med. 112:296-308. https://doi.org/10. 1016/i.prevetmed.2013.07.018.

Coignard, M., R. Guatteo, I. Veissier, A. Lehébel, C. Hoogveld, L. Mounier, and N. Bareille. 2014. Does milk yield reflect the level of welfare in dairy herds? The Vet. J. 199:184-187. http://dx.doi.org/10.1016/j.tvjl.2013.10.011.

Collings, L.K.M., D.M. Weary, N. Chapinal, and M.A.G. von Keyserlingk. 2011. Temporal feed restriction and overstocking increase competition for feed by dairy cattle. J. Dairy Sci. 94:5480-5486. https://doi.org/10.3168/jds. 2011-4370.

Cook, N.B., J.P. Hess, M.R. Foy, T.B. Bennett, and R.L. Brotzman. 2016. Management characteristics, lameness, and body injuries of dairy cattle housed in high-performance dairy herds in Wisconsin. J. Dairy Sci. 99:5879-5891. https://doi.org/10.3168/jds.2016-10956.

Cook, N.B., J.P. Hess, M.R. Foy, T.B. Bennett, and R.L. Brotzman. 2016. Management characteristics, lameness, and body injuries of dairy cattle housed in high-performance dairy herds in Wisconsin. J. Dairy Sci. 99:5879-5891. https://doi.org/10.3168/jds.2016-10956.

Cook, N.B., T.B. Bennett, and K.V. Nordlund. 2004. Effect of free stall surface on daily activity patterns in dairy cows with relevance to lameness prevalence. J. Dairy Sci. 87:2912-2922. https://doi.org/10.3168/jds.S0022-0302(04) 73422-0.

Cramer, G., K.D. Lissemore, C.L. Guard, K.E. Leslie, and D.F. Kelton. 2009. Herd-level risk factors for seven different foot lesions in Ontario Holstein cattle housed in tie stalls or free stalls. J. Dairy Sci. 92:1404-1411. https:// doi.org/ 10.3168/jds.2008-1134.

Dahlhoff, K. 2014. Beratung von milchviehhaltenden Betrieben auf der Basis von Verhaltens- und Erscheinungsparametern ihrer Milchkühe. Dissertation. Rheinische Friedrich-Wilhelms-Universität Bonn. http://hss.ulb.uni-bonn .de/ 2014/3657/3657.pdf. 
Dairy Australia, 2015. Cows and farms. www. dairyaustralia.com.au/Markets-andstatistics/Farm-facts/Cows-and-Farms.aspx (Accessed 10. February 2017).

Dairy New Zealand. 2014. New Zealand Dairy Statistics 2013-2014. www.dairynz.co.nz/media/1327583/nz-dairy-statistics-2013-2014-web.pdf (Accessed 10. February 2017).

De Boyer des Roches, A., I. Veissier, M. Coignard, N. Bareille, R. Guatteo, J. Capdeville, E. Gilot-Fromont, and L. Monier. 2014. The major welfare problems of dairy cows in French commercial farms: an epidemiological approach. Anim. Welf. 23:467-478. https://doi.org/10.7120/09627286.23. 4.467.

De Boyer des Roches, A., I. Veissier, X. Boivin, E. Gilot-Fromont, and L. Mounier. 2016. A prospective exploration off arm, farmer, and animal characteristics in human-animal relationships: An epidemiological survey. J. Dairy Sci. 99:5573-5585. http://dx.doi.org/10.3168/jds.2015-10633.

De Graaf, S., B. Ampe, and F.A.M. Tuyttens. 2017. Assessing dairy cow welfare at the beginning and end of the indoor period using the Welfare Quality ${ }^{\circledR}$ protocol. Anim. Welf. 26: 213-221. https://doi.org/10.7120/09627286. 26.2. 213.

De Graaf, S., B. Ampe, C. Winckler, M. Radeski, L. Mounier, M.K. Kirchner, M.J. Haskell, F.J.C.M. van Eerdenburg, A. de Boyer des Roches, S.N. Andreasen, J. Bijttebier, L. Lauwers, W. Verbeke, and F.A.M. Tuyttens. 2017b Trained-user opinion about Welfare Quality measures and integrated scoring of dairy cattle welfare. J. Dairy Sci. 100:6376-6388. https://doi.org/ 10.3168/jds.2016-12255.

De Graaf, S., B. Ampe, S. Buijs, S.N. Andreasen, A. De Boyer des Roches, F.J.C.M. van Eerdenburg, M.J. Haskell, M.K. Kirchner, L. Mounier, M. Radeski, C. Winckler, J. Bijttebier, L. Lauwers, W. Verbeke, and F.A.M. Tuyttens. 2018. Sensitivity of the integrated Welfare Quality ${ }^{\circledR}$ scores to changing values of individual dairy cattle welfare measures. Anim. Welf. 27:157-166. https://doi.org/10.7120/09627286.27.2.157.

De Vries, A., H. Dechassa, and H. Hogeveen. 2016. Economic evaluation of stall stocking density of lactating dairy cows. J. Dairy Sci. 99:3448-3857. https://doi.org/10.3168/jds.2015-10556.

De Vries, M., E.A.M. Bokkers, C.G. van Reenen, B. Engel, G. van Schaik, T. Dijkstra, and I.J.M. de Boer. 2015. Housing and management factors associated with indicators of dairy cattle welfare. Prev. Vet. Med. 118:80-92. https://doi.org/10.1016/i.prevetmed. 2014.11.016. 
De Vries, M., E.A.M. Bokkers, G. van Schaik, B. Engel, T. Dijkstra, and J.M. de Boer. 2014. Exploring the value of routinely collected herd data for estimating dairy cattle welfare. J. Dairy Sci. 97:715-730. http://dx.doi.org/ 10.3168/jds.2013-6585.

De Vries, M., E.A.M. Bokkers, G. van Schaik, B. Engel, T. Dijkstra, and I.J.M. de Boer. 2016. Improving the time efficiency of identifying dairy herds with poorer welfare in a population. J. Dairy Sci. 99:8282-8296. http://dx.doi. org/10.3168/jds.2015-9979.

De Vries, M., E.A.M. Bokkers, G. van Schaik, B. Engel, T. Dijkstra, and J.M. de Boer. 2014. Exploring the value of routinely collected herd data for estimating dairy cattle welfare. J. Dairy Sci. 97:715-730. http://dx.doi.org/ 10.3168/jds.2013-6585.

De Vries, M., E.A.M. Bokkers, G. van Schaik, R. Botreau, B. Engel, T. Dijkstra, and I.J.M. de Boer. 2013. Evaluating results of the Welfare Quality multicriteria evaluation model for classification of dairy cattle welfare at the herd level. J. Dairy Sci. 96:6264-6273. http://dx.doi.org/10.3168/jds.2012-6129.

De Vries, M., E.A.M. Bokkers, T. Dijkstra, G. van Schaik, and I.J.M. de Boer. 2011. Invited review: Associations betwess variables of routine herd data and dairy cattle welfare indicators. J. Dairy Sci. 94:3213-3228. https://doi .org/ 10.3168/jds.2011-4169.

Deimel, I., A. Franz, M. Frentrup, M. von Meyer, A. Spiller, L. Theuvsen, J. Dettmer, M. Gauly, C. Salzborn, L. Schrader, and H. van den Weghe. 2010. Perspektiven für ein europäisches Tierschutzlabel. BLE Projekt- kennziffer 08HS010. http://download.ble.de/08HS010.pdf (Zuletzt geprüft am: 15. 12.2017).

Destatis. 2008. Land- und Forstwirtschaft, Fischerei Rinder- und Schweinebestand Statistisches Bundesamt. Fachserie 3 Reihe 4.1. https:// www.destatis.de/GPStatistik/servlets/MCRFileodeServlet/DEHeft_derivate_00004129/2030213079004.pdf (Accessed 07. October 2017).

Destatis. 2011. Land- und Forstwirtschaft, Fischerei Rinder- und Schweinebestand Statistisches Bundesamt. Fachserie 3 Reihe 4.1. https:// www.destatis.de/GPStatistik/servlets/MCRFileodeServlet/DEHeft_derivate_00004135/2030213109004.pdf (Accessed 07. October 2017).

Destatis. 2014. Land- und Forstwirtschaft, Fischerei Rinder- und Schweinebestand Statistisches Bundesamt. Fachserie 3 Reihe 4.1. https://www. destatis.de/GPStatistik/servlets/MCRFileNodeServlet/DEHeft_derivate_ 00013372/2030213139004.pdf (Accessed 07. October 2017).

Destatis. 2017. Land- und Forstwirtschaft, Fischerei Rinder- und Schweinebestand Statistisches Bundesamt. Fachserie 3 Reihe 4.1. https://www. 
destatis.de/GPStatistik/servlets/MCRFileNodeServlet/DEHeft_derivate_ 00032776/2030213169004.pdf (Accessed 07. October 2017).

DeVries, T.J., M.A.G. von Keyserlingk, and K.A. Beauchemin. 2005. Frequency of feed delivery affects the behavior of lactating dairy cows. J. Dairy. Sci. 88:3553-3562. https://doi.org/10.3168/jds.S0022-0302(05)73040-X.

DeVries, T.J., M.G. Aarnoudse, H.W. Barkema, K.E. Leslie, and M.A.G. von Keyserlingk. 2012. Associations of dairy cow behavior, barn hygiene, cow hygiene, and risk of elevated somatic cell count. J. Dairy Sci. 95:5730-5739. http://dx.doi.org/10.3168/ jds.2012-5375.

Dippel, S., M. Dolezal, C. Brenninkmeyer, J. Brinkmann, S. March, U. Knierim, and C. Winckler. 2009. Risk factors for lameness in cubicle housed Austrian Simmental dairy cows. Prev. Vet. Med. 90:102-112. http://dx.doi.org/ 10.1016/j.prevetmed.2009.03.014.

Doherr, M.G., M. Roesch, W. Schaeren, M. Schallibaum, and J.W. Blum. 2007. Risk factors associated with subclinical mastitis in dairy cows on Swiss organic and conventional production system farms. Vet. Med. 52:487-495. https://doi.org/10.17221/2060-VETMED.

Dohmen, W., F. Neijenhuis, and H. Hogeveen. 2010. Relationship between udder health and hygiene on farms with an automatic milking system. J. Dairy Sci. 93:4019-4033. https://doi.org/10.3168/jds.2009-3028.

EFSA. 2010. Animal welfare risk assessment guidelines on housing and management. Technical report (EFSA-Q-2009-00844). Wageningen UR Livestock Research. http://www.efsa.europa.eu/en/supporting/pub/en-87. (Accessed 04. November 2017).

Ellis, K.A., K. Billington, B. McNeil, and D.E.F. McKeegan. 2009. Public opinion on UK milk marketing and dairy cow welfare. Anim. Welf. 18:267-282. ISSN: 0962-7286.

Endres, M.I., and L.A. Espejo. 2010. Feeding management and characteristics of rations for high-producing dairy cows in freestall herds. J. Dairy Sci. 93:822-829. https://doi.org/10.3168/jds.2008-2007.

Ermann, M., M. Fahlbusch, S. Kühl, B. Brümmer und B. Schulze-Ehlers. 2017. Der Markt für Milch und Milcherzeugnisse im Jahr 2016. Ger. J. Agric. Econ. 66:44-63.

Espejo, L.A. and M.I. Endres. 2007. Herd-level risk factors for lameness in highproducing Holstein cows housed in freestall barns. J. Dairy Sci. 90, 306314. https://doi.org/10.3168/jds.S0022-0302(07)72631-0. 
Espejo, L.A., M.I. Endres, and J.A. Salfer. 2006. Prevalence of Lameness in HighProducing Holstein Cows Housed in Freestall Barns in Minnesota. J. Dairy Sci. 89:3052-3058. https://doi.org/ 10.3168/jds.S0022-0302(06)72579-6.

Estevez, I., I.L. Andersen, and E. Naevdal. 2007. Group size, density and social dynamics in farm animals. Appl. Anim. Beh. Sci. 103:185-204. https://doi. org/10.1016/j.applanim.2006.05.025.

European Commission. 2016. Attitudes of Europeans towards animal welfare. Special Eurobarometer442. http://ec.europa.eu/COMMFrontOffice/publicopinion/index.cfm/Survey/getSurveyDetail/instruments/SPECIAL/surveyKy/2096 (Accessed 05. September 2017).

Eurostat. 2015. Milk and milk products - 30 years of quotas. Historical data on the milk sector (1983-2013). http://ec.europa.eu/eurostat/statistics-explained/index.php/Milk_and_milk_products_-_30_years_of_quotas (Accessed 10. May 1017).

Fabian, J., R.A. Laven, and H.R. Whay. 2014. The prevalence of lameness on New Zealand dairy farms: A comparism of farmer estimate and locomotion scoring. The Vet. J. 201:31-38. http://dx.doi.org/10.1016/j.tvjl.2014.05. $\underline{011 .}$

Falk, A.C., D.M. Weary, C. Winckler, and M.A.G. von Keyserlingk. 2012. Preference for pasture versus freestall housing by dairy cattle when stall availability indoors is reduced. J. Dairy Sci. 95:6409-6415. https://doi.org/10. 3168/jds.2011-5208.

Faulkner, P.M., and D.M. Weary. 2000. Reducing pain after dehorning in dairy calves. J. Dairy Sci. 83:2037-2041. https://doi.org/10.3168/jds.S0022-03 02(00)75084-3.

FAWC (1993): Report on Priorities for Animal Welfare Research and Development. Farm Animal Welfare Council. http://www.fawc.org.uk/pdf/old/animal-welfare-priorities-report-may1993.pdf (Zuletzt geprüft am: 15.12. 2017).

Fourichon, C., F. Beaudeau, N. Bareille, and H. Seegers. 2001. Incidence of health disorders in dairy farming systems in western France. Livest. Prod. Sci. 68:157-170. https://doi.org/ 10.1016/S0301-6226(00)00249-9.

Fregonesi, J.A., and J.D. Leaver. 2002. Influence of space allowance and milk yield level on behavior, performance and health of dairy cows housed in strawyard and cubicle systems. Livest. Prod. Sci. 78:245-257. https://doi. org/ 10.1016/S0301-6226(02)00097-0. 
Fregonesi, J.A., C.B. Tucker, and D.M. Weary. 2007. Overstocking reduces lying time in dairy cows. J. Dairy Sci. 90:3349-3354. https://doi.org/10.3168 jids.2006-794.

Gauly, M., H. Bollwein, G. Breves, K. Brügeman, S. Dänicke, ,G. Das, J. Demeler, H. Hansen, J. Isselstein, S. König, M. Lohölter, M. Martinsohn, U. Meyer, M. Potthoff, C. Sanker, B. Schröder, N. Wrage, B. Meibaum, G. von Samson-Himmelstjerna, H. Stinshoff, and C. Wrenzycki. 2013. Future consequences and challenges for dairy cow production systems arising from climate change in Central Europe - a review. Animal. 7:843-859. https://doi. org/10.1017/S1751731112002352.

German Animal Welfare Society. 2018. Animal welfare label - Guidelines for dairy cattle. https://www.tierschutzlabel.info/fileadmin/user_upload/Dokumente/Milchk\%C3\%BChe/Richtlinie_Milchkuehe_2.0.pdf. (Accessed 07. September 2018).

Gieseke, D., C. Lambertz, I. Traulsen, J. Krieter, and M. Gauly. 2014. Beurteilung von Tiergerechtheit in der Milchviehhaltung - Evaluierung des Welfare Quality ${ }^{\circledR}$ Protokolls. Züchtungskunde. 86:58-70. ISSN 0044-5401.

Goff, J.P. 2008. The monitoring, prevention and treatment of milk fever and subclinical hypocalcemia in dairy cows. The Vet. J. 176:50-57. https://doi. org/10.1016/j.tvil.2007.12.020.

Gottardo, F., E. Nalon, B. Contiero, S. Normando, P. Dalvit, and G. Cozzi. 2011. The dehorning of dairy calves: practices and opinions of 639 farmers. J. Dairy Sci. 94:5724-5734. https://doi.org/10.3168/jds.2011-4443.

Grant, R.J., and J.L. Albright. 2001. Effect of animal grouping on feeding behavior and intake of dairy cattle. J. Dairy Sci. 84:156-163. https://doi.org/10. 3168/jds.S0022-0302(01)70210-X.

Green, L.E., V.J. Hedges, Y.H. Schukken, R.W. Blowes, and A.J. Packington. 2002. The Impact of Clinical Lameness on the Milk Yield of Dairy Cows. J. Dairy Sci. 85:2250-2256. https://doi.org/10.3168/jds.2011-4443.

Haskell, M.J., L.J. Rennie, V.A. Bowell, M.J. Bell, and A.B. Lawrende. 2006. Housing System. Milk Production, and Zero-Grazing Effects on Lameness and Leg Injury in Dairy Cows. J. Dairy Sci. 89:4259-4266. https://doi.org/ 10.3168/jds.S0022-0302(06)72472-9.

Heath, C.A.E., W.J. Browne, S. Mullan, and D.C.J. Main. 2014b. Navigating the iceberg: reducing the number of parameters within the Welfare Quality ${ }^{\circledR}$ Assessment protocol for dairy cows. Animal. 8: 1978-1986. https://doi.org/ $\underline{10.1017 / S 1751731114002018 .}$ 
Heath, C.A.E., Y. Lin, S. Mullan, W.J. Browne, and D.C.J. Main. 2014a. Implementing Welfare Quality ${ }^{\circledR}$ in UK assurance schemes: evaluating the challenges. Anim. Welf. 23: 95-107. https://doi.org/10.7120/0962728623.1.0 $\underline{95 .}$

Heise, H. 2017. Tierwohl in der Nutztierhaltung: Eine Stakeholder-Analyse. Dissertation Georg-August-Universität Göttingen. https://ediss.uni-goettingen.de/bitstream/handle/11858/00-1735-0000-0023-3DFF-C/Dissertation 31.03.2017.pdf?sequence $=1$.

Hemsworth, P. H., J.L. Barnett, and G.J. Coleman. 2009. The integration of human-animal relations into animal welfare monitoring schemes. Anim. Welf. 18: 335-345.

Hill, C.T., P.D. Krawczel, H.M. Mann, C.S. Ballard, R.C. Hovey, W.A. Falls, and R.J. Grant. 2009. Effect of stocking density on the short-term behavioural responses of dairy cows. Appl. Anim. Beh. Sci. 117:144-149. https://doi. org/10.1016/..applanim.2008.12.012.

Hosseinkhani, A., T.J. DeVries, K.L. Proudfoot, R. Valizadeh, D.M. Veira, and M.A.G. von Keyserlingk. 2008. The effects of feed bunk competition on the feed sorting behavior of close-up dry cows. J. Dairy Sci. 91:1115-1121. https://doi.org/10.3168/jds.2007-0679.

Hovinen, M., and S. Pyörälä. 2011. Invited review: Udder health of dairy cows in automatic milking. J. Dairy Sci. 94:547-562. https://doi.org/10.3168/jds.20 10-3556.

Huzzey, J.M., T.J. DeVries, P. Valois, and M.A.G. von Keyserlingk. 2006. Stocking density and feed barrier design affect the feeding and social behavior of dairy cattle. J. Dairy Sci. 89:126-133. https://doi.org/10.3168/jds.S00220302(06)72075-6.

Ingham, S.C., Y. Hu, and C. Ané. 2011. Comparison of bulk-tank standard plate count and somatic cell count for Wisconsin dairy farms in three size categories. J. Dairy Sci. 94:4237-4241. https://doi.org/10.3168/jds.2011-4310.

Ingvartsen, K.L., R.J. Dewhurst, and N.C: Friggens. 2003. On the relationship between lactational performance and health: is it yield or metabolic imbalance that cause production diseases in dairy cattle? A position paper. Livest. Prod. Sci. 83:277-308. https://doi.org/10.1016/S0301-6226 (03)00 110-6.

Ito, K., N. Chapinal, D.M. Weary, and von M.A.G. Keyserlingk. 2014. Associations between herd-level factors and lying behavior of freestall-housed dairy cows. J. Dairy Sci. 97:2081-2089. https://doi.org/10.3168/jds.2013-6861. 
Ivemeyer, S., U. Knierim, and S. Waiblinger. 2011. Effect of human-animal relationship and management on udder health in Swiss dairy herds. J. Dairy Sci. 94: 5890-5902. https://doi.org/10.3168/jds.2010-4048.

Jacobs, J.A., and J.M. Siegford. Invited review: The impact of automatic milking systems on dairy cow management, behavior, health, and welfare. J. Dairy sci. 95:2227-2247. https://doi.org/10.3168/jds.2011-4943.

Jensen, M.B., and K.L. Proudfoot. 2017. Effect of group size and health status on behavior and feed intake of multiparous dairy cows in early lactation. J. Dairy. Sci. 100:9759-9768. https://doi.org/10.3168/jds.2017-13035.

Johnsen, P. F., T. Johannesson, and P. Sandoe. 2001. Assessment of farm animal welfare at herd level - Many goals, many methods. Acta Agric. Scand., A, 30:26-33. https://doi.org/10.1080/0906470013 16923027.

Kadzere, C.T., M.R. Murphy, N. Silanikove, and E. Maltz. 2002. Heat stress in lactating dairy cows: a review. Livest. Prod. Sci. 77:59-91. https://doi.org/ 10.1016/S0301-6226(01) 00330-X.

Katainen, A., M. Norring, E. Manninen, J. Laine, T. Orava, K. Kuoppala, and H. Saloniemi. 2005. Competitive behavior of dairy cows at a concentrate selffeeder. Acta Agric. Scand. A Anim. Sci. 55:98-105. https://doi.org/10.1080 109064700500239453.

Kester, E., M. Holzhauer, and K. Frankena. 2014. A descriptive review of the prevalence and risk factors of hock lesions in dairy cows. Vet. J. 202: 222228. https://doi.org/10.1016/j.tvjl.2014.07.004.

Kielland, C., L.E. Ruud, A.J. Zanella, and O. Osteras. 2009. Prevalence and risk factors for skin lesions on legs of dairy cattle housed in freestalls in Norway. J. Dairy Sci. 92:5487-5496. https://doi.org/10.3168/jds.2009-2293.

King, M.T.M., E.A. Pajor, S.J. LeBlanc, and T.J. DeVries. 2016. Associations of herd-level housing, management, and lameness prevalence with productivity and cow behavior in herds with automated milking systems. J. Dairy Sci. 99:9069-9079. http://dx.doi.org/10.3168/jds.2016-11329.

Knierim, U. 1998a. Wissenschaftliche Konzepte zur Beurteilung der Tiergerechtheit im englischsprachigen Raum. In: KTBL (Hrsg.): Beurteilung der Tiergerechheit von Haltungssystemen. Kuratorium für Technik und Bauwesen in der Landwirtschaft-Verlag. KTBL-Schrift 377, Darmstadt, 31-39.

Knierim, U. 2002. Grundsätzliche ethologische Überlegungen zur Beurteilung der Tiergerechtheit bei Nutztieren. Dtsch. Tierärztl. Wochenschr. 109 (6): 261266.

Knierim, U., and C. Winckler. 2009. On-farm welfare assessement in cattle - Validity, reliability and feasibility issues and future perspectives with special 
regard to the Welfare Quality apply. Anim. Welf. 18:451-458. ISSN 0962$\underline{7286 .}$.

Koivula, M., E.A. Mätysaari, E. Negussie, and T. Serenius. 2005. Genetic and phenotypic relationships among milk yield and somatic cell count before and after clinical mastitis. J. Dairy Sci. 88:827-833. https://doi.org/10.31 68/jds.S0022-0302(05)72747-8.

Krawczel, P.D., C.S. Mooney, H.M. Dann, M.P. Carter, R.E. Butzler, C.S. Ballard, and R.J. Grant. 2012a. Effect of alternative models for increasing stocking density on the short-term behavior and hygiene of Holstein dairy cows. J. Dairy Sci. 95:2467-2475. https://doi.org/10.3168/jds.2011-4686.

Krawczel, P.D., L.B. Klaiber, R.E. Butzler, L.M. Klaiber, H.M. Dann, C.S. Mooney, and R.J. Grant. 2012b. Short-term increases in stocking density affect the lying and social behavior, but not the productivity, of lactating Holstein dairy cows. J. Dairy Sci. 95:4298-4308. https://doi.org/10.3168/jds.20114687.

Krystallis, A., M. Dutra de Barcellos, J.O. Kügler, W. Verbeke, and K.G. Grunert. 2009. Attitudes of European citizens towards pig production systems. Livest. Sci. 126:46-56. https://doi.org/10.1016/j.livsci.2009.05.016.

Leach, K.A., H.R. Whay, C.M. Maggs, Z.E. Barker, E.S. Paul. A.K. Bell and D.C.J. Main. 2010. Working towards a reduction in cattle lameness: 1 . Understanding barriers to lameness control on dairy farms. Res. Vet. Sci. 89:311-317. https://doi.org/10.1016/j.rvsc.2010.02.014.

Lievaart, J.J., H.W. Barkema, W.D.J. Kremer, J. van den Broek, J.H.M. Verheijden, and J.A.P. Heesterbeek. 2007. Effect of herd characteristics, management practices, and season on different categories of the herd somatic cell count. J. Dairy Sci. 90:4137-4144. https://doi.org/10.3168/jds. 2006-847.

Lindena, T., R. Ellßel und H. Hansen. 2017. Steckbrief zur Tierhaltung in Deutschland - Milchkühe. Thünen-Institut. Braunschweig.https://www. thuenen.de/media/tithemenfelder/Nutztierhaltung_und_Aquakultur/Nutztierhaltung_und_Fleischproduktion/Milchviehhaltung/Steckbrief_Milchkuehe.pdf. (Zuletzt geprüft: 01.01.2018).

Lombard, J.E., C.B. Tucker, M.A.G. von Keyserlingk, C.A. Kopral and D.M. Weary. 2010. Associations between cow hygiene, hock injuries, and free stall usage on US dairy farms. J. Dairy Sci. 93, 4668-4676.

Lucy, M.C. 2001. ADSA Foundation Scholar Award. Reproductive Loss in HighProducing Dairy Cattle: Where will it end? J. Dairy Sci. 84:1277-1293. https ://doi.org/ 10.3168/jds.S0022-0302(01)70158-0. 
M'hamdi, N., C. Darej, and R. Bouraoui. 2013. Animal welfare issues concerning procedures of calves dehorning. App. Sci. Report. 4.234-240. ISSN: 23110139.

MacDonald, J. M., E. J. O'Donoghue, W. D. McBride, R. F. Nehring, C. L. Sandretto, and R. Mosheim. 2007. Profits, costs, and the changing structure of dairy farming. www.ers.usda.gov/media/188030/err47_1_.pdf (Accessed 10. April 2015).

Main, D. C. J., C. Leeb, H.R. Whay, M. Hovi, and J. Webster. 2004. Bristol Welfare Assurance Programme. Animal based assessment tool for farm animal welfare certification. http://www.vetschool.bris.ac.uk/animalwelfare/ images/BWAPweboverview.pdf (Zuletzt geprüft am: 15.12.2017).

Main, D. C. J., H.R. Whay, C. Leeb, and A.J.F. Webster. 2007. Formal animalbased welfare assessment in UK certification schemes. Anim. Welf. 16:233-236. ISSN 0962-7286.

Main, D. C. J., J.P. Kent, F. Wemelsfelder, E. Ofner, and F.A.M. Tuyttens. 2003. Applications for methods of on-farm welfare assessment. Anim. Welf. 12:523-528. ISSN 0962-7286.

Manteca, X., A. Velarde, and B. Jones. 2009. Animal Welfare components. In: Smulders, F. J. M. and Algers, B. (Hrsg.): Welfare of production animals. Wageningen Academic Publishers, Wageningen, 61-77.

Mattiello, S., C. Klotz, D. Baroli, M. Minero, V. Ferrante, and E. Canali. 2009. Welfare problems in alpine dairy cattle farms in Alto Adige (Eastern Italian Alps). Ital. J. Anim. Sci. 8: 628-630. https://doi.org/10.4081/ijas.2009.s2. $\underline{628 .}$

Miele, M., I. Veissier, A. Evans, and R. Botreau. 2011. Animal welfare - Establishing a dialogue between science and society. Anim. Welf. 20:103-117. ISSN 0962-7286.

Napolitano, F., U. Knierim, F. Grasso, and G. de Rosa. Positive indicators of cattle welfare and their applicability to on-farm protocols. Ital. J. Anim. Sci. 8:355-365. https://doi.org/10.4081/ijas.2009.s1.355.

Nash, C.G.R., D.F. Kelton, T.J. DeVries, E. Vasseur, J. Coe, J.C. Zaffino Heyerhoff, V. Bouffard, D. Pellerin, J. Rushen, A.M. de Passillé, and D.B. Haley. 2016. Prevalence of and risk factors for hock and knee injuries on dairy cows in tiestall housing in Canada. J. Dairy Sci. 99:6494-6506. https:// doi.org/10.3168/jds.2015-10676.

Neves, R.C., B.M. Leno, T. Stokol, T.R. Overton, and J.A.A. McArt. 2017. Risk factors associated with postpartum subclinical hypocalcemia in dairy cows. J. Dairy Sci. 100:3796-3804. https://doi.org/10.3168/jds.2016-11970. 
Nier, S., H. Bäuerle und C. Tamásy. 2013. Die deutsche Milchviehhaltung im Strukturwandel. ISPA-Mitteilungen 81, Vechta.

Nyman, A.-K., T. Ekman, U. Emanuelson, A.H. Gustafsson, K. Holtenius, K. Persson Waller and C. Hallén Sandgreen. 2007. Risk factors associated with the incidence of veterinary-treated clinical mastitis in Swedish dairy herds with a high milk yield and a low prevalence of subclinical mastitis. Prev. Vet. Med. 78:142-160. https://doi.org/10.1016/j.prevetmed.2006.10. 002.

Olde Riekerink, R.G.M., H.W. Barkema, D.F. Kelton, and D.T. Scholl. 2008. Incidence rate of clinial mastitis on Canadian dairy farms. J. Dairy Sci. 91:1366-1377. https://doi.org/10.3168/jds.2007-0757.

Oleggini, G.H., L.O. Ely, and J.W. Smith. 2001. Effect of region and herd size on dairy herd performance parameters. J. Dairy Sci. 84:1044-1050. https:// doi.org/10.3168/jds.S0022 -0302(01)74564-X.

Palacio, S., L. Peignier, C. Pachoud, C. Nash, S. Adam, R. Bergeron, D. Pellerin, A.M. de Passillé, J. Rushen, D. Haley, T.J. DeVries, and E. Vasseur. 2017. Technical Note: Assessing lameness in tie-stalls using live stall lameness scoring. J. Dairy Sci. 100:6577-6582. https://doi.org/ 10.3168/jds.201612 171.

Pelzer, A. 2007. Cows and more: Was die Kühe uns sagen! In: WGMEV (Hrsg.): Jahrestagung 2007, 36-38.

Petherick, J.C., and C.J.C. Phillips. 2009. Space allowances for confined livestock and their determination from allometric principles. Appl. Anim. Beh. Sci. 117:1-12. https://doi.org/10.1016/10.1016/j.applanim.2008.09.008.

Phytian, C., E. Michalopoulou, J. Duncan, and F. Wemelsfelder. 2013. Inter-observer reliability of qualitative behavioural assessments of sheep. Appl. Anim. Beh. Sci. 144:73-79. https://doi.org/10.1016/j.applanim.2012. $\underline{11.011 .}$

Plaizier, J.C., D-O- Krause, G.N. Gozho, and B.W. McBride. 2008. Subcacute ruminal acidosis in dairy cows: The physiological causes, incidence and consequences. The Vet. J. 176:21-31. https://doi.org/10.1016/j.tvjl.2007. 12.016.

Plesch, G., N. Broerkens, S. Laister, C. Winckler, and U. Knierim. 2010. Reliability and feasibility of selected measures concerning resting behaviour for the on-farm welfare assessment in dairy cows. Appl. Anim. Beh. Sci. 126:1926. https://doi.org/10.1016/j.applanim.2010.05.003.

Popescu, S., C. Borda, E.A. Diugan, M. Niculae, R. Stefan, and C.D. Sandru. 2014. The effect of the housing system on the welfare quality of dairy cows. Ital. J. Anim. Sci. 13:2940. https://doi.org/10.4081/ijas.2014.2940. 
Popescu, S., C. Borda, E.A. Diugan, M. Spinu, I.S. Groza, and C.D. Sandru. 2013. Dairy cows welfare quality in tie-stall housing system with or without access to exercise. Acta Vet. Scand. 55: 43-54. https://doi.org/10.1186/ 1751-0147-55-43.

Potterton, S.L., M.J. Green, J. Harris, K.M. Millar, H.R. Whay, and J.N. Huxley. 2011. Risk factors associated with hair loss, ulceration, and swelling at the hock in freestall-housed UK dairy herds. J. Dairy Sci. 94:2952-2963. https ://doi.org/10.3168/jds.2010-4084.

Prickett, R.W., F.B. Norwood, and J.L. Lusk. 2010. Consumer preferences for farm animal welfare: results from a telephone survey of US households. Anim. Welf. 19: 335-347. ISSN 0962-7286.

Proudfoot, K., and G. Habing. 2015. Social stress as a cause of diseases in farm animals: Current knowledge and future directions. Vet. J. 206:15-21. https://doi.org/10.1016/j.tvjl.2015.05.024.

Raboisson, D., M. Moumié, and E. Maigné. 2014. Disease, reproductive performance and changes in milk production associated with subclinical ketosis in dairy cows: A meta-analysis and review. J. Dairy Sci. 97: 7547-7563. https://doi.org/10.3168/jds.2014-8237.

Raussi, S. 2003. Human-cattle interactions in group housing. Appl. Anim. Beh. Sci. 80:245-262. https://doi.org/10.1016/S0168-1591(02)00213-7.

Robbins, J.A., D.M. Weary, C.A. Schuppli, and M.A.G. von Keyserlingk. 2015. Stakeholder views on treating pain due to dehorning dairy calves. Anim. Welf. 24:399-406. https://doi.org/10.7120/09627286.24.4.399.

Robbins, J.A., M.A.G. von Keyserlingk, D. Fraser, and D.M. Weary. 2016. Invited review: Farm size and animal welfare. J. Anim. Sci. 94:5439-5455. https:// doi.org/10.2527/jas.2016-0805.

Roche, J.R., N.C. Friggens, J.K. Kay, M.W. Fisher, K.J. Stafford, and D.P. Berry. 2009. Invited review: Body condition score and its association with dairy cow productivity, health, and welfare. J. Dairy Sci. 92:5769-5801. https:// doi.org /10.3168/jds.2009-2431.

Rodrigues, A.C.O., D.Z. Caraviello, and P.L. Ruegg. 2005. Management of Wisconsin dairy herds enrolled in milk quality teams. J. Dairy Sci. 88:26602671. https://doi.org/ 10.3168/jds.S0022-0302(05)72943-X.

Rouha-Mülleder, C., C. Iben, E. Wagner, G. Laaha, J. Troxler, and S. Waiblinger. 2009. Relative importance of factors influencing the prevalence of lameness in Austrian cubicle loose-housed dairy cows. Prev. Vet. Med. 92:123133. https://doi.org/10.1016/j.prevetmed.2009.07.008. 
Rousing, T., and F. Wemelsfelder. 2006. Qualitative assessment of social behavior of dairy cows housed in loose housing systems. Appl. Anim. Beh. Sci. 101:40-53. https://doi.org/10.1016/i.applanim.2005.12.009.

Rousing, T., I.A. Jakobsen, J. Hindhede, I.C. Klaas, M. Bonde, and J.T. Sorensen. 2007. Evaluation of a welfare indicator protocol for assessing animal welfare in AMS herds - Researcher, production advisor and veterinary practitioner opinion. Anim. Welf. 16: 213-216. ISSN 0962-7286.

Ruegg, P.L., and J.C.F. Pantoja. 2013. Understanding and using somatic cell counts to improve milk quality. Irish. J. Agr. Food. Res. 52:101-117. http:// hdl.handle.net/11019/525.

Rushen, J. 2003. Changing concepts of farm animal welfare - Bridging the gap between applied and basic research. Appl. Anim. Beh. Sci. 81:199-214. https://doi.org/10.1016/S0168-1591(02)00281-2.

Rushen, J., and A.M. de Passillé. 2009. The scientific basis of animal welfare indicators. In: Smulders, F. J. M. and Algers, B. (Hrsg.): Welfare of production animals. Wageningen Academic Publishers, Wageningen, 391-415.

Ruud, L.E., K.E. Boe, and O. Osteras. 2010. Risk factors for dirty dairy cows in Norwegian freestall systems. J. Dairy Sci. 93:5216-5224. https://doi.org/ 10.3168/jds.2010-3321.

Sanders, A.H., J.K. Shearer, and A. De Vries. 2009. Seasonal incidence of lameness and risk factors associated with thin soles, white line disease, ulcers, and sole punctures in dairy cattle. J. Dairy Sci. 92:3165-3174. https:// doi.org/ 10.3168/jds.2008-1799.

Sandoe, P., B. Forkman, F. Hakansson, S.N. Andreasen, R. Nohr, M. Denwood, and T.B. Lund. 2017. Should the contribution of one additional lame cow depend on how many other cows on the farm are lame? Animals. 7:96108. https://doi.org/10.3390/ani7120096.

Sandoe, P., S.B. Christiansen, and M.C. Appleby. 2003. Farm animal welfare The interaction of ethical questions and animal welfare science. Anim. Welf. 12:469-478. ISSN 0962-7286.

Sanftleben, P., U. Knierim, H.-J. Herrmann, C. Müller, and E. von Borell. 2007. Kritische Kontrollpunkte (CCP) in der Milchrinderhaltung. Züchtungskunde 79 (5): 339-362. ISSN 0044-5401.

Schewe, R.L., J. Kayitsinga, G.A. Contreras, C. Odom, W.A. Coats, P. Durst, E.P. Hovingh, R.O. Martinez, R. Mobley, S. Moore, and R.J. Erskine. 2015. Herd management and social variables associated with bulk tank somatic cell count in dairy herds in the eastern United States. J. Dairy Sci. 98:76507665. https://doi.org/10.3168/jds.2014-8840. 
Schrader, L. 2009. Tierschutz und Tierhaltung in der Milchviehhaltung. Züchtungskunde 81(6):414-420. ISSN 0044-5401.

Schuppli, C.A., M.A.G. von Keyserlingk, and D.M. Weary. 2014. Access to pasture for dairy cows: responses from an online engagement. J. Anim. Sci. 92:5185-5192. https://doi.org/10.2527/jas2014-7725.

Simensen, E., O. Osteras, K.E. Boe, C. Kielland, L.E. Ruud, and G. Naess. 2010. Housing system and herd size interactions in Norwegian dairy herds; associations with performance and disease incidence. Acta. Vet. Scand. 52:14. https://doi.org/10.1186/1751-0147-52-14.

Smith, J.W., L.O. Ely, W.M. Graves, and W.D. Gilson. 2002. Effect of milking frequency on DHI performance measures. J. Dairy Sci. 85:3526-3533. https://doi.org/10.3168/jds.S0022-0302(02)74442-1.

Sogstad, A.M., O. Osteras, and T. Fjeldaas. 2006. Bovine claw and limb disorders related to reproductive performance and production diseases. J. Dairy Sci. 89:2519-2528. https://doi.org/10.3168/jds.S0022-0302(06)72327-X.

Solano, L., H. W. Barkema, E. A. Pajor, S. Mason, S. J. LeBlanc, J. C. Zaffino Heyerhoff, C. G. R. Nash, D. B. Haley, E. Vasseur, D. Pellerin, J. Rushen, A. M. de Passillé, and K. Orsel. 2015. Prevalence of lameness and associated risk factors in Canadian Holstein-Friesian cows housed in freestall barns. J. Dairy Sci. 98:6978-6991. https://doi.org/10.3168/jds.2015-9652.

Sorensen, J.T, and D. Fraser. 2010. On-farm welfare assessment for regulatory purposes: issues and possible solutions. Live. Sci. 131:1-7. https://doi.org /10.1016/j.livsci.2010.02.025.

Sova, A.D., S.J. LeBlanc, B.W. McBride, and T.J. DeVries. 2013. Associations between herd-level feeding management practices, feed sorting, and milk production in freestall dairy farms. J. Dairy Sci. 96:4759-4770. https:// doi.org/10.3168/jds.2013-6679.

Spinka, M. 2006. How important is natural behavior in animal farming systems? Appl. Anim. Beh. Sci. 100:117-128. https://doi.org/10.1016/j.applanim. 2006.04.006.

Spooner, J.M., C.A. Schuppli, and D. Fraser. 2014. Attitudes of Canadian citizens toward animal welfare: A qualitative study. Livest. Sci. 163:150-158. https: //doi.org/10.1016/j.livsci.2014.02.011.

Stankovic, B., S. Hristov, D. Ostojic-Andric, Z. Zlatanovic, Lj. Samalovac, and N. Maksimovic. 2014. The most common health disorders and welfare of dairy cows and calves. Biotech. Anim. Husb. 30:549-560. https://doi.org/ 10.2298/BAH1404549S. 
Stengärde, L., J. Hultgren, M. Travén, K. Holtenius, and U. Emanuelson. 2012. Risk factors for displaced abomasums or ketosis in Swedish dairy herds. Prev. Vet. Med. 103:280-286. https://doi.org/10.1016/j.prevetmed.2011. $\underline{09.005 .}$

Stock, M.L., S.L. Baldridge, D. Giffin, and J.F. Coetzee. 2013. Bovine dehorning - assessing pain and providing analgesic. Vet. Clin. Food. Anim. 29:103133. http://dx.doi.org/10.1016/j.cvfa.2012.11.001.

Stone, W.C. 2004. Nutritional approaches to minimize subacute ruminal acidosis and laminitis in dairy cattle. J. Dairy Sci. 87:13-26. https://doi.org/10.3168/ ids.S0022-0302(04)70057-0.

Sundrum, A., and R. Andersson. 1994. Tiergerechtheitsindex TGI. In: Sundrum, A., Andersson, R. und Postler, G. (Hrsg.): Tiergesundheitsindex 200 - Ein Leitfaden zur Beurteilung von Haltungssystemen. Köllen Druck + Verlag GmbH, Bonn, 20-29.

Takai, H., S. Pedersen, J.O. Johnsen, J.H.M. Metz, P.W.G. Groot Koerkamp, G.H. Uenk, V.R. Phillips, M.R. Holden, R.W. Sneath, J.L. Short, R.P. White, J. Hartung, J. Seedorf, M. Schröder, K.H. Linkert, and C.M. Wathes. 1998. Concentrations and Emissions of Airborne Dust in Livestock Buildings in Northern Europe. J. Agric. Engng. Res. 70:59-77. https://doi.org/ 10.1006/jaer.1997.0280.

Telezhenko, E., M.A.G. von Keyserlingk, A. Talebi, and D.M. Weary. 2012. Effect of pen size, group size, and stocking density on activity in freestall-housed dairy cows. J. Dairy Sci. 95:3064-3069. https://doi.org/10.3168/jds.20114953.

Torres-Cardona, M.G., M.E. Ortega-Cerrilla, J.I. Alejos-de la Fuente, J. HerreraHaro, and J.G. Peralta Ortiz. 2014. Effect of regrouping Holstein cows on milk production and physical activity. J. Anim. Plant Sci. 22:3433-3438. ISSN 2071-7024.

Tremetsberger, L., C. Leeb, and C. Winckler. 2015. Animal health and welfare planning improves udder health and cleanliness but not leg health in Austrian dairy herds. J. Dairy Sci. 98:6801-6811. http://dx.doi.org/10.3168/ ids.2014-9084.

TSchG. 2017. Tierschutzgesetz. https://www.gesetze-im-internet.de/tierschg/ BJNR012770972.html. (Letzter Zugriff: 11.01.2018).

USDA. 2010. Facility characteristics and cow comfort on U.S. dairy operations. United States Department of Agriculture. http://www.aphis.usda.gov/animal_health/nahms/dairy/downloads/dairy07/Dairy07_ir_Facilities.pdf. (Accessed 07. October 2017). 
Val-Laillet, D., D.M. Veira, and M.A.G. von Keyserlingk. 2008. Short communication: Dominance in free-stall-housed dairy cattle is dependent upon resource. J. Dairy Sci. 91:3922-3926. https://doi.org/10.3168/jds.2008-1332.

Van Os, J.M.C., C. Winckler, J. Trieb, S.V. Matarazzo, T.W. Lehenbauer, J.D. Champagne, and C.B. Tucker. 2018. Reliability of sampling strategies for measuring dairy cattle welfare on commercial farms. J. Dairy Sci. 101:1495-1504. https://doi.org/10.3168/jds.2017-13611.

Vanhonacker, F., and W. Verbeke. 2014. Public and consumer policies for higher welfare food products: challenges and opportunities. J. Agric. Environ. Ethics. 27:153-171. https:// doi.org/10.1007/s10806-013-9479-2.

Vanhonacker, F., W. Verbeke, E. Van Poucke, and F.A.M. Tuyttens. 2008. Do citizens and farmers interpret the concept of farm animal welfare differently? Live. Sci. 116:126-136. https://doi.org/10.1016/..livsci.2007. 09.017.

Veissier, I., A. Aubert, and A. Boissy. 2012. Animal Welfare - A result of animal background and perception of its environment. Anim. Front., 2 (3):7-15. https://doi.org/10.2527/af.2012-0043.

Veissier, I., J. Capdeville, and E. Delval. 2004. Cubicle housing systems for cattle: Comfort of dairy cows depends on cubicle adjustment. J. Anim. Sci. 82:3321-3337. https://doi.org/ 10.2527/2004.82113321x.

Veissier, I., R. Botreau, and P. Perny. 2009. Scoring animal welfare - Difficulties and Welfare Quality ${ }^{\circledR}$ Solutions. In: Keeling, L. (Hrsg.): An Overview of the Development of the Welfare Quality ${ }^{\circledR}$ Project Assessment Systems. Welfare Quality ${ }^{\circledR}$, Lelystad, 15-32.

Ventura, B.A., M.A.G. von Keyserlingk, and D.M. Weary. 2015. Animal welfare concerns and values of stakeholders within the dairy industry. J. Agric. Environ. Ethics. 28:109-126. https://doi.org/10.1007/s10806-014-9523-x.

Ventura, B.A., M.A.G. von Keyserlingk, C.A. Schuppli, and D.M. Weary. 2013. Views on contentious practices in dairy farming: The case of early cowcalf separation. J. Dairy Sci. 96:6105-6116. http://dx.doi.org/10.3168/jds. 2012-6040.

Verbeke, W. 2009. Stakeholder, citizen and consumer interests in farm animal welfare. Anim. Welf. 18:325-333. ISSN 0962-7286.

Vereinigte Informationssysteme Tierhaltung (VIT). 2016. Trends, Fakten, Zahlen. https://www.vit.de/fileadmin/Wir-sind-vit/Jahresberichte/vit-JB2016-ges amt.pdf. (Accessed 15.12.2017).

Verkerk, G.A., and P.H. Hemsworth. 2010. Managing cow welfare in large dairy herds. Pages 436-443 in Proc. of the $4^{\text {th }}$ Australasian Dairy Science Symposium. Lincoln University, Christchurch, New Zealand. 
Von Keyserlingk, M.A.G., A. Barrientos, K. Ito, E. Galo and D.M. Weary. 2012. Benchmarking cow comfort on North American freestall dairies: Lameness, leg injuries, lying time, facility design, and management for high-producing Holstein dairy cows. J. Dairy Sci. 95, 7399-7408. https://doi.org/ 10.3168/ jds.2012-5807.

Von Keyserlingk, M.A.G., J. Rushen, A.M. de Passillé, and D.M. Weary. 2009. Invited review: the welfare of dairy cattle - key concepts and the role of science. J. Dairy Sci. 92:4101-4111. https://doi.org/10.3168/jds.2009-23 26.

Wagner, K., J. Brinkmann, S. March, P. Hinterstoißer, S. Warnecke, M. Schüler, and H.M. Paulsen. 2018. Impact of daily grazing time on dairy cow welfare - results oft he welfare quality ${ }^{\circledR}$ protocol. Animals. 8:1-11. https://doi.org/ 10.3390/ani8010001.

Waiblinger, S. 2012. Die Bedeutung der Veterinärmedizin für den Tierschutz. In: Grimm, H. and Otterstedt, C. (Hrsg.): Das Tier an sich - Disziplinenübergreifende Perspektiven für neue Wege im wissenschaftsbasierten Tierschutz. Vandenhoeck und Ruprecht Verlag, Göttingen, 172-197.

Waiblinger, S., and C. Menke. 1999. Influence of herd size on human-cow relationships. Anthrozoos. 12:240-247. https://doi.org/10.2752/089279399787 $\underline{000156 .}$

Waiblinger, S., C. Menke, and D.W. Fölsch. 2003. Influences on the avoidance and approach behavior of dairy cows towards humans on 35 farms. Appl. Anim. Beh. Sci. 84:23-39. https://doi.org/10.1016/S0168-1591(03)00148$\underline{5 .}$

Waiblinger, S., C. Menke, and G. Coleman. 2002. The relationship between attitudes, personal characteristics and behavior of stockpeople and subsequent behavior and production of dairy cows. Appl. Anim. Beh. Sci. 79:195-219. https://doi.org/10.1016/S0168-1591(02)00155-7.

Waiblinger, S., U. Knierim, and C. Winckler. 2001. The development of an epidemiologically based on-farm welfare assessment system for use with dairy cows. Acta Agric. Scand. A, 51 (30):73-77. https://doi.org/10.1080/09064 7001316923108.

Wang, F.X., D.F. Shao, S.L. Li, Y.J. Wang, A. Azarfar, and Z.J. Cao. 2016. Effects of stocking density on behavior, productivity, and comfort indices of lactating dairy cows. J. Dairy Sci. 99:3709-3717. https://doi.org/10.3168/jds. 2015-10098.

Weary, D.M., and M.A.G. von Keyserlingk. 2017. Public concerns about dairycom welfare: how should the industry respond? Anim. Prod. Sci. 57:12011209. http://dx.doi.org/10.1071/AN16680. 
Webster, A. J. F. 2003. Assessment of animal welfare at farm and group level Introduction and overview. Anim. Welf. 12:429-431. ISSN 0962-7286.

Webster, A.J.F. 2001. Effects of housing and two forage diets on the development of claw horn lesions in dairy cows at first calving and in first lactation. Vet. J. 162:56-65. https://doi.org/10.1053/tvil.2001.0569.

Webster, J. 2005. The assessment and implementation of animal welfare - Theory into practice. Rev. Sci. Tech. 24 (2):723-734. PMID:16358522.

Wechsler, B., J. Schaub, K. Friedli, and R. Hauser. 2000. Behaviour and leg injuries in dairy cows kept in cubicle systems with straw bedding or soft lying mats. Appl. Anim. Beh. Sci. 69:189-197. https://doi.org/10.1016/S016815 91(00)00134-9.

Weinrich, R., S. Kühl, A. Franz, and A. Spiller. 2015. Consumer Preferences for High Welfare Meat in Germany: Self-service Counter or Service Counter? Int. J. Food Syst. Dynam. 6:32-49. https://doi.org/10.18461/ijfsd.v6i1.614.

Welfare Quality. 2012. Welfare Quality ${ }^{\circledR}$ Assessment protocol for cattle. Welfare Quality ${ }^{\circledR}$ Consortium, Lelystad, Netherlands. www.welfarequalitynetwork. net/network/45848/7/0/40 (Accessed 21. August 2017).

Wemelsfelder, F. 2007. How animals communicate quality of life: the qualitative assessment of behavior. Anim. Welf. 16:25-31. ISSN 0962-7286.

Wemelsfelder, F., T.E.A. Hunter, M.T. Mendl, and A.B. Lawrence. 2001. Assessing the whole animal: a free choice profiling approach. Anim. Beh. 62:209-220. https://doi.org/10.1006/anbe.2001.1741.

Wenz, J.R., S.M. Jensen, J.E. Lombard, B.A. Wagner, and R.P. Dinsmore. 2007. Herd management practices and their association with bulk tank somatic cell count on United States dairy operations. J. Dairy Sci. 90:3652-3659. https://doi.org/10.3168/jds.2006-592.

Whay, H. R. 2007. The journey to animal welfare improvement. Animal Welfare, 16:117-122. ISSN 0962-7286.

Whitaker, D.A., A.I. Macrae, and E. Burrough. 2004. Disposal and disease rates in British dairy herds between April 1998 and March 2002. Vet. Rec. 155:43-47. https://dx.doi.org/10.1136/vr.155.2.43.

Widmar, N.O., C.J. Morgan, C.A. Wolf, E.A. Yeager, S.R. Dominick, and C.C. Croney. 2017. US resident perceptions of dairy cattle management practices. Agric. Sci. 8:645-656. https://doi.org/10.4236/as.2017.87049.

Winckler, C., C.B. Tucker and D. Weary. 2015. Effects of under- and overstocking freestalls on dairy cattle behavior. Appl. Anim. Beh. Sci. 170, 14-19. https: //doi.org/10.1016/j.applanim.2015.06.003. 
Winckler, C., J. Brinkmann, and J. Glatz. 2007. Long-term consistency of selected animal-related welfare parameters in dairy farms. Anim. Welf. 16:197-199. ISSN 0962-7286.

Winckler, C., J. Capdeville, G. Gebresenbet, B. Hörning, U. Roiha, M. Tosi, and S. Waiblinger. 2003. Selection of parameters for on-farm welfare-assessement protocols in cattle and buffalo. Anim. Welf. 12:619-624. ISSN 0962-7286.

Wissenschaftlicher Beirat Agrarpolitik beim BMEL (WBA). 2015. Wege zu einer gesellschaftlich akzeptierten Nutztierhaltung. Gutachten. Berlin.

Wolf, C.A., G.T. Tonsor, M.G.S. McKendree, D.U. Thomson, and J.C. Swanson. 2016. Public and farmer perceptions of dairy cattle welfare in the United States. J. Dairy Sci. 99:5892-5903. http://dx.doi.org/10.3168/jds.201510619.

Zaffino Heyerhoff., J.C., S.J. LeBlanc, T.J. DeVries, C.G.R. Nash, J. Gibbons, K. Orsel, H.W. Barkema, L. Solano, J. Rushen, A.M. de Passillé, and D.B. Haley. 2014. Prevalence of and factors associated with hock, knee, and neck injuries on dairy cows in freestall housing in Canada. J. Dairy Sci. 97:173-184. https://dx.doi.org/10.3168/jds.2012-6367.

Zapf, R., U. Schultheiß, W. Achilles, L. Schrader, U. Knierim, H.-J. Herrmann, J. Brinkmann, and C. Winckler. 2015. Indicators for on-farm self-assessment of animal welfare - Example: dairy cows. Landtechnik. 70:221-230. https:// doi.org/10.15150/lt.2015.2678.

Zuliani, A., A. Romanzin, M. Corazzin, S. Salvador, J.C. Abrahantes, and S. Bovolenta. 2017. Welfare assessment in traditional mountain dairy farms: above and beyond resource-based measures. Anim. Welf. 26:203-211. https://doi.org/10.7120/09627286.26.2.203. 


\section{DANKSAGUNG}




\section{Danksagung}

Zunächst möchte ich mich bei meinem Doktorvater Herrn Prof. Dr. Dr. Matthias Gauly für die Vergabe des spannenden Promotionsthemas „Tierwohl in der Milchviehhaltung", die fachliche Unterstützung aus dem schönen Bozen und die Geduld in den vergangenen Jahren bedanken.

Darüber hinaus gilt mein Dank meinem Zweitprüfer Herrn Prof. Dr. Christoph Winckler und seinem Team, die mich intensiv in der Anwendung des Welfare Quality ${ }^{\circledR}$ Protokolls geschult haben und mir im Rahmen meiner Forschungsaufenthalte an der BOKU in Wien mit Rat und Tat zur Seite standen.

Herzlichen Dank auch an Herrn Prof. Dr. Achim Spiller für die Bereitschaft als Drittprüfer an meiner Disputation teilzuhaben und die gute Zusammenarbeit in meiner Zeit als studentischer Mitarbeiter an seinem Lehrstuhl.

Einen besonderen Dank möchte ich zudem Herrn Dr. Christian Lambertz ausprechen, der mich bei der statistischen Analyse des Datensatzes und dem Verfassen der einzelnen Aufsätze auf großartige Weise unterstützt hat.

Es war mir ein großes Vergnügen als assoziierter Doktorand am Promotionsprogramm "Animal Welfare in Intensive Livestock Production Systems" teilzunehmen und bedanke mich bei allen Doktorandlnnen für die gemeinsame Zeit!

Herzlichen Dank auch an alle KollegInnen aus der Arbeitsgruppe „Systeme der Nutztierhaltung" für die gute fachliche Zusammenarbeit, fröhliche Stunden abseits des Büroalltags und die denkwürdigen Exkursionen im In- und Ausland.

Ein weiterer Dank gilt Frau Prof. Dr. Ute Knierim und meinen KollegInnen aus der aktuellen Arbeitsgruppe „Nutztierethologie und Tierhaltung" von der Universität Kassel-Witzenhausen. Herzlichen Dank für die Unterstützung im letzten Jahr!

Desweiteren möchte ich mich beim Bundesministerium für Bildung und Forschung (BMBF) für die Förderung des Projekts „Nachhaltiges Landmanagement im Norddeutschen Tiefland (NaLaMa-nt)", sowie bei der H. Wilhelm Schaumann Stiftung und der Göttinger Graduiertenschule Gesellschaftswissenschaften (GGG) für die finanzielle Unterstützung des Promotionsvorhabens bedanken.

Mein größter Dank gilt jedoch meiner Familie, die mir immer den Rücken gestärkt und dadurch den erfolgreichen Abschluss meiner Promotion erst ermöglicht hat! 


\section{LEBENSLAUF}




\section{Lebenslauf}

Persönliche Angaben

Name:

Daniel Gieseke

Geboren:

11. Januar 1984 in Göttingen

E-Mail:

daniel.gieseke@uni-kassel.de

Familie:

verheiratet, 2 Kinder

Berufliche Tätigkeit

03/2017 - heute

\section{Wissenschaftlicher Mitarbeiter}

Universität Kassel

Fachbereich Ökologische Agrarwissenschaften

Fachgebiet Nutztierethologie und Tierhaltung (Prof. Knierim)

- Wissenschaftliche Bearbeitung des Projekts Eikotiger (Praxistauglichkeit von Tierschutzindikatoren bei der betrieblichen Eigenkontrolle, Erarbeitung eines Bewertungsrahmens sowie technische Umsetzung in digitalen Anwendungen) [Geflügel]

02/2013-03/2017 Wissenschaftlicher Mitarbeiter

Georg-August-Universität Göttingen

Department für Nutztierwissenschaften (DNTW)

Abt. Systeme der Nutztierhaltung (Prof. Traulsen); Abt. Produktionssysteme der Nutztiere (Prof. König v. Borstel / Prof. Gauly)

- Wissenschaftliche Bearbeitung des Projekts GröWohl (Untersuchungen zum Einfluss der Bestandsgröße auf das Tierwohl in der konventionellen Milchviehhaltung)

- Wissenschaftliche Bearbeitung des Projekts NaLaMa-nt (Analyse von Produktionsverfahren bei Schwein und Rind zur optimierten Anpassung an wechselnde Umweltbedingungen)

- Promotionsprogramm „Animal Welfare in Intensive Livestock Production Systems“" (Assoziierter Doktorand)

- Elternzeit von 10/2015 - 12/2015 und 02/2016 - 05/2016

Studienzeit

02/2013-02/2018

\section{Promotions-Studium Agrarwissenschaften}

Georg-August-Universität Göttingen

- Schwerpunkt Animal Welfare

11/2010 - 01/2013 Master-Studium Agrarwissenschaften

Georg-August-Universität Göttingen

- Schwerpunkt Tierproduktion

10/2007 - 10/2010 Bachelor-Studium Agrarwissenschaften

Georg-August-Universität Göttingen

- Schwerpunkt Tierproduktion 
Veröffentlichungen

\section{Publikationen}

\section{Konferenzen}

- Gieseke, D.; Lambertz, C. und Gauly, M. (2018) Relationship between herd size and measures of animal welfare on dairy cattle farms with freestall housing in Germany. Journal of Dairy Science. 101:7397-7411. https://doi.org/ 10.3168/jds.2017-14232.

- Gieseke, D.; Busch, G.; Ikinger, C.; Kühl, S. und Pirsich, W. (2015) Tierhaltung im Spannungsfeld von Tierwohl, Ökonomie und Gesellschaft [Tagungsband zur Tierwohltagung 2015 in Göttingen], ISBN 978-3-9815926-5-8

- Gieseke, D.; Lambertz, C.; Traulsen, I.; Krieter, J. und Gauly, M. (2014) Beurteilung von Tiergerechtheit in der Milchviehhaltung - Evaluierung des Welfare Quality ${ }^{\circledR}$ Protokolls. Züchtungskunde, 86 (1) S. 58-70, ISSN 00445401

- Gieseke, D.; Dierkes, L.; Montag, S.; Lambertz, C. und Gauly, M. (2017) Seasonal effects on animal welfare assessment in dairy cattle. Poster auf der Tagung Assessment of Animal Welfare at Farm and Group Level in Wageningen (Niederlande)

- Gieseke, D.*; Lambertz, C. und Gauly, M. (2016) Besteht ein Zusammenhang zwischen Ressourcenausstattung und Leistungs- und Tierwohlparametern bei Milchkühen? Vortrag auf der Tagung der Deutschen Gesellschaft für Züchtungskunde in Hannover

- Gieseke, D.; Lambertz, C.* und Gauly, M. (2016) Does herd size affect animal welfare in dairy cattle? Vortrag auf der Tagung der European Federation of Animal Science in Belfast (Nordirland)

- Gieseke, D*.; Lambertz, C. und Gauly, M. (2015) Untersuchungen zum Einfluss der Bestandsgröße auf tierbezogene Verhaltensindikatoren bei Milchkühen. Poster auf der Tagung der Deutschen Veterinärmedizinischen Gesellschaft in Freiburg 
- Gieseke, D.*; Lambertz, C. und Gauly, M. (2015) Besteht ein Zusammenhang zwischen Bestandsgröße und Tierwohl in der konventionellen Milchviehhaltung? Vortrag auf der Tagung der Deutschen Gesellschaft für Züchtungskunde in Berlin

- Gieseke, D.*; Lambertz, C. und Gauly, M. (2015) Zusammenhang von Nutzungsdauer und Tierwohl bei Milchkühen. Kurzvortrag und Poster auf der Tagung Bau, Technik und Umwelt in Weihenstephan

- Gieseke, D.*; Lambertz, C. und Gauly, M. (2015) Effects of milk yield on animal welfare in dairy cattle. Vortrag auf der Tagung der European Federation of Animal Science in Warschau (Polen)

- Gieseke, D.*; Lambertz, C. und Gauly, M. (2014) Untersuchungen zum Zusammenhang von Leistung und Tierwohl bei Milchkühen. Vortrag auf der Tagung der Deutschen Gesellschaft für Züchtungskunde in Dummersdorf

- Gieseke, D.* (2013) Beurteilung von Tiergerechtheit in der Milchviehhaltung - Evaluierung des Welfare Quality ${ }^{\circledR}$ Protokolls“. Vortrag auf der Tagung der Deutschen Gesellschaft für Züchtungskunde in Göttingen

Nörten-Hardenberg, den 27.09.2018 


\section{Anhang}

Supplemental Table S1: Data collected for the assessment of the animal welfare level of lactating dairy cows using the Welfare Quality ${ }^{\circledR}$ protocol (modified by Coignard et al., 2013). Modifications of the WQP are highlighted in bold.

\section{Welfare Indicator Source ${ }^{1} \quad \begin{aligned} & \text { Frequency } \\ & \text { calculation }^{2}\end{aligned} \quad$ Method for collecting data}

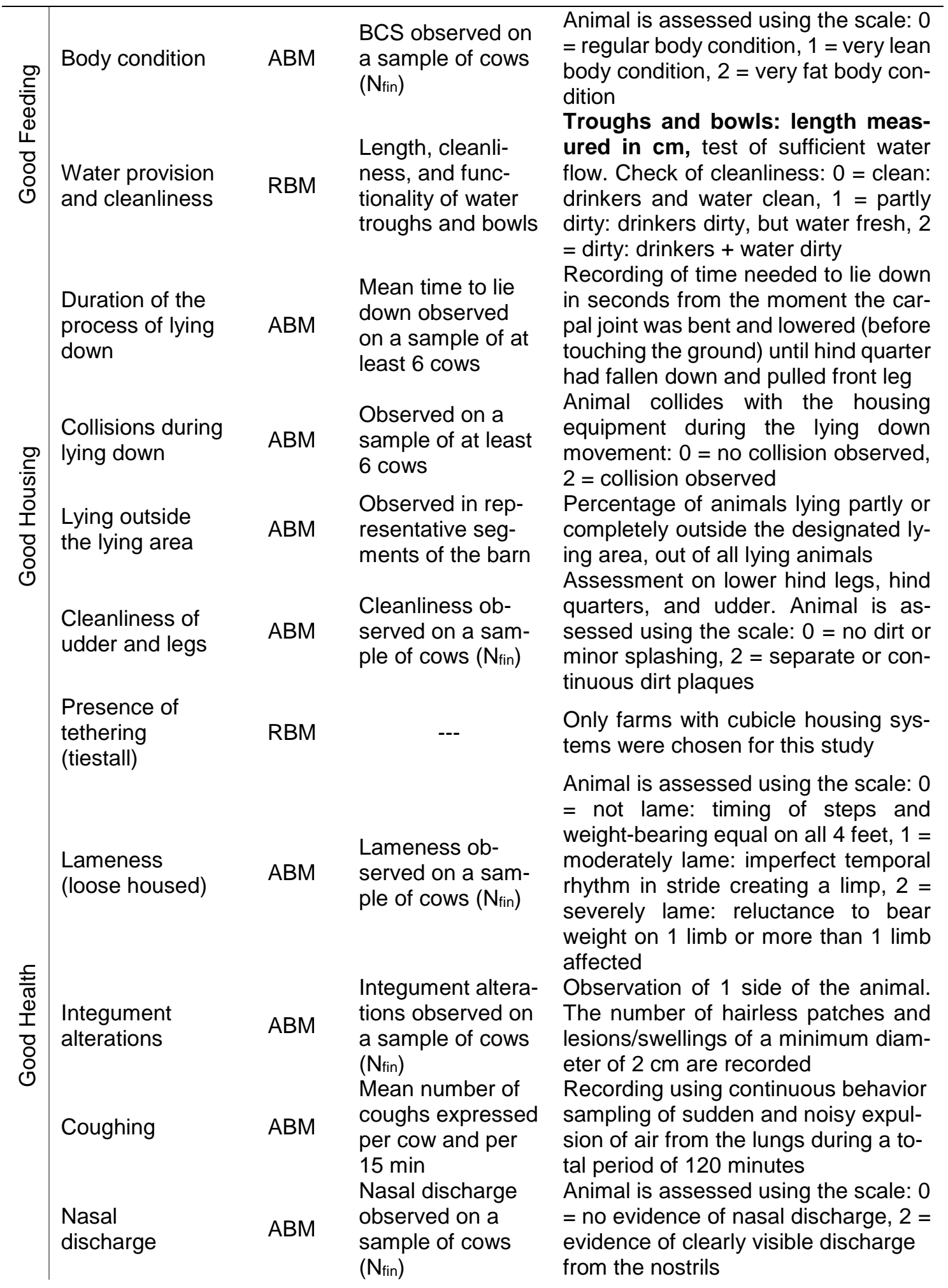


Ocular

discharge

Hampered

respiration

Diarrhea

Vulvar

discharge

Milk somatic

cell count

Mortality

Dystocia

Downer cows

Disbudding/

dehorning

Tail docking

QUE

Agonistic

behavior

Access to

pasture

Avoidance

distance test

Qualitative

behavior

assessment

QUE

ABM

ABM
Ocular discharge observed on a sample of cows $\left(\mathrm{N}_{\text {fin }}\right)$

Hampered respiration observed on a sample of cows $\left(\mathrm{N}_{\text {fin }}\right)$

Diarrhea ob-

ABM served on a sample of cows $\left(\mathrm{N}_{\mathrm{fin}}\right)$

Vulvar discharge observed on a sample of cows (Nin)

Cows with subclinical mastitis within the last 3 months (milk recording)

Annual cumulative incidence of mortality

Annual cumulative incidence of dystocia Annual cumulative incidence of downer cows

Observed in representative segments of the barn

Days per year with at least 6 hours at pasture

Observed on a sample of cows $\left(\mathrm{N}_{\text {fin }}\right)$

Observed in representative segments of the barn
Animal is assessed using the scale: 0 $=$ no evidence of ocular discharge, 2 $=$ evidence of clearly visible discharge (wet/dry); at least $3 \mathrm{~cm}$ Animal is assessed using the scale: 0 $=$ no evidence of hampered respiration, 2 = evidence of deep and labored respiration

Animal is assessed using the scale: 0 $=$ no evidence of diarrhea, 2 = evidence of watery manure on both sides of the tail; > size of a hand Animal is assessed using the scale: 0 $=$ no evidence of vulvar discharge, 2 $=$ evidence of purulent effluent from the vulva

Cow milk somatic cell counts are assessed using the scale: 0 = SCC below $400,000 \mathrm{cell} / \mathrm{mL}$ for the last 3 months, 2 = SCC above 400,000 cell $/ \mathrm{mL}$ at least once in the last 3 months

Defined as the percentage of dairy cows which died or were euthanized by a veterinarian or emergency slaughtered during last 12 months Defined as percentage of calvings where major assistance was required during the last 12 months

Defined as percentage of severe cases of downer cows during the last 12 months (>24 h lying)

Farmer is asked about management practices for disbudding/dehorning of the calves or dairy cows (procedures, anesthetics/analgesics).

Not practiced in Germany except an emergency case (legislation)

Recording using continuous behavior sampling during a total period of 120 minutes: number of head butts, displacements, chases and fights

Number of days per year on pasture, number of hours per day on pasture

Starting at $2 \mathrm{~m}$ distance at the feed bunk; observer approached with an extended hand. If cow showed withdrawal, avoidance distance was estimated between hand and the muzzle Behavioral observation of the herd for being active, relaxed, fearful, agitated, calm, content, indifferent, frustrated, friendly, bored, playful, positive, lively, inquisitive, irritable, uneasy, sociable, apathetic, happy, or distressed

${ }^{1} \mathrm{ABM}$ = animal based measure; RBM = resource based measure; QUE = questionnaire

${ }^{2} \mathrm{~N}_{\text {fin }}=$ sample size according to Welfare Quality (2012). 


\section{Datenerhebung Welfare Quality ${ }^{\circledR}$ Protokoll}

\section{1.) Betriebsspiegel}

Betriebsname:

Arbeitskräfteausstattung:

Betriebstyp:

Familien-AK

Betriebsleiter:

Fremd-AK

Anschrift:

Telefon/-fax:

Mobiltelefon:

E-Mailadresse:

Anzahl Hektar:

Grünland

Ackerland

Anzahl der Milchkühe:

Gesamt

Laktierend

Durchschnittliche Herdenleistung in den letzten 3 Jahren:

Durchschnitt Fett (\% / KG):

Durchschnitt Eiweiß (\%/KG):

Sonstige Anmerkungen: 


\section{2.) Management}

$>$ Liegeboxenlaufstall

$\square \quad$ Strohstall

Anbindehaltung

$>$ Ganzjährige Stallhaltung? $\quad \square \quad$ Ja $\quad \square \quad$ Nein

- Wenn nein, welcher Weidetyp?

- Wie viele Stunden pro Tag?

- Wie viele Tage pro Jahr?

Zugang zu Laufhof?

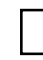

$\mathrm{Ja}$

$\square \quad$ Nein

- Wenn ja, wie viel Fläche?

- Wie viele Stunden pro Tag?

- Wie viele Tage pro Jahr?

Zellzahlgehalt

\begin{tabular}{|l|l|l|}
\hline Tiere in Kontrolle & Kühe $<400.000$ Zellen $/ \mathrm{ml}$ & Kühe $>\mathbf{4 0 0 . 0 0 0 ~ Z e l l e n} / \mathbf{m l}$ \\
\hline 3 Monate & & \\
\hline 2 Monate & & \\
\hline 1 Monat & & \\
\hline Gesamt (Anzahl) & & \\
\hline Prozent (\%) & & \\
\hline
\end{tabular}

Kennzahlen der Gesundheit

- Anzahl der eingeschläferten/verendeten/notgeschlachteten Tiere in den letzten 12 Monaten? Durchschnittsbestand?

- Anzahl der Schwergeburten in den letzten 12 Monaten? Durchschnittliche Anzahl von Geburten?

- Anzahl der festliegenden Kühe in den letzten 12 Monaten? Durchschnittsbestand? 
$>$ Enthornung

Wie wird enthornt?

Keine $\square$ mit Säure $\square$ thermische

Entfernen der ausgewachsenen Hörner

Wird bei der Enthornung

Lokalanästhesie gegeben

Betäubungsmittel gegeben

Schmerzmittel gegeben

Weder noch

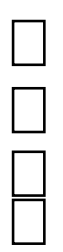

Zeitpunkt der Enthornung: Wochen

Schwanzkürzen ?

Ja $\square \quad$ Nein

\section{3.) Haltungsumwelt}

Art der Tränken:

Anzahl der Tränken pro Kuhgruppe:

Anzahl der Kühe pro Kuhgruppe:

Anzahl Kuhgruppen pro Betrieb:

Tier-Tränken-Verhältnis:

\begin{tabular}{|c|c|c|c|c|c|c|c|c|c|c|}
\hline & 1 & 2 & 3 & 4 & 5 & 6 & 7 & 8 & 9 & 10 \\
\hline $\begin{array}{l}\text { Art der Tränke } \\
(\mathrm{T} / \mathrm{B})\end{array}$ & & & & & & & & & & \\
\hline $\begin{array}{l}\text { Tränkenlänge } \\
\text { pro Tier }(\mathrm{cm}) \text { : }\end{array}$ & & & & & & & & & & \\
\hline $\begin{array}{l}\text { Durchfluss des } \\
\text { Schwimmers } \\
\text { (I/min): }\end{array}$ & & & & & & & & & & \\
\hline $\begin{array}{l}\text { Tränken sauber? } \\
(0 / 1 / 2)\end{array}$ & & & & & & & & & & \\
\hline $\begin{array}{l}\text { Funktionieren alle } \\
\text { Tränken? }(0 / 2)\end{array}$ & & & & & & & & & & \\
\hline
\end{tabular}


4.) Tierorientiert

Benötigte Zeit zum Abliegen in Sekunden

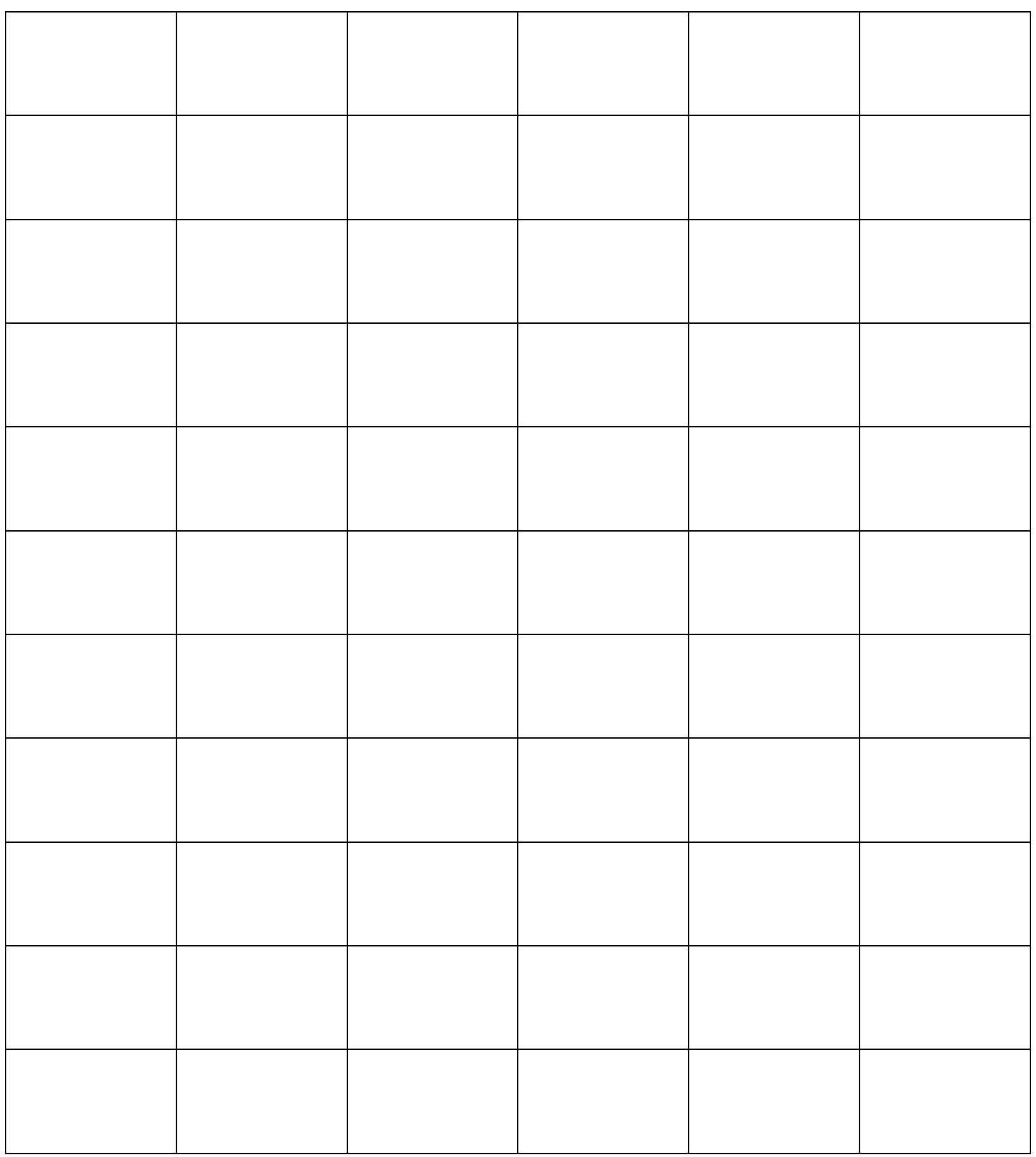

Kollision von Tieren mit den Liegeboxeneinrichtungen

Liegen Tiere ganz oder teilweise außerhalb der Liegeboxen?

s. Hustentabelle 


\section{Husten}

Beobachtungsdauer: 120 Minuten, Segmente a 25 Kühe, möglichst nur 6 Segmente Anzahl Husten:

\begin{tabular}{|c|c|c|c|c|}
\hline BP & 1. Beobachtung & 2. Beobachtung & $\begin{array}{c}\text { Dauer (min) pro } \\
\text { Segment }\end{array}$ & $\begin{array}{l}\text { Spaltenlieger } \\
\text { pro Segment }\end{array}$ \\
\hline 1 & & & 120 & \\
\hline 2 & & & 30 & \\
\hline 3 & & & 20 & \\
\hline 4 & & & 15 & \\
\hline 5 & & & 12 & \\
\hline 6 & & & 10 & \\
\hline 7 & & & & \\
\hline 8 & & & 15 & \\
\hline 9 & & & & \\
\hline 10 & & & 12 & \\
\hline 11 & & & & \\
\hline 12 & & & & \\
\hline
\end{tabular}




\section{Sozialverhalten}

Aggressives Verhalten: Kopfstoß, Vertreiben, Jagd, Kampf, Verfolgung

\begin{tabular}{|c|c|c|c|c|c|c|c|c|c|c|c|}
\hline \multirow{2}{*}{ BP } & \multicolumn{3}{|c|}{ 1. Beobachtung } & \multicolumn{3}{|c|}{ 2. Beobachtung } & \multicolumn{2}{|c|}{$\begin{array}{l}\text { Tiere im } \\
\text { Segment }\end{array}$} & \multicolumn{2}{|c|}{$\begin{array}{c}\text { davon lie- } \\
\text { gend }\end{array}$} & \multirow[t]{2}{*}{$\begin{array}{l}\text { Dauer } \\
\text { (min) }\end{array}$} \\
\hline & $\begin{array}{l}\text { Kopf- } \\
\text { stoß }\end{array}$ & $\begin{array}{l}\text { Vertrei- } \\
\text { ben }\end{array}$ & $\begin{array}{l}\text { Sonsti- } \\
\text { ges }\end{array}$ & $\begin{array}{l}\text { Kopf- } \\
\text { stoß }\end{array}$ & $\begin{array}{l}\text { Ver- } \\
\text { treiben }\end{array}$ & $\begin{array}{c}\text { Sonst- } \\
\text { iges }\end{array}$ & $A$ & $E$ & $A$ & $\mathrm{E}$ & \\
\hline 1 & & & & & & & & & & & 120 \\
\hline 2 & & & & & & & & & & & 30 \\
\hline 3 & & & & & & & & & & & 20 \\
\hline 4 & & & & & & & & & & & 15 \\
\hline 5 & & & & & & & & & & & 12 \\
\hline 6 & & & & & & & & & & & 10 \\
\hline 7 & & & & & & & & & & & \\
\hline 8 & & & & & & & & & & & 15 \\
\hline 9 & & & & & & & & & & & \\
\hline 10 & & & & & & & & & & & 12 \\
\hline 11 & & & & & & & & & & & \\
\hline 12 & & & & & & & & & & & 10 \\
\hline
\end{tabular}

Fluchtdistanz zum Menschen in 10cm Abständen:

\begin{tabular}{|l|l|l|l|l|l|l|l|l|l|}
\hline & & & & & & & & & \\
\hline & & & & & & & & & \\
\hline \\
\hline
\end{tabular}


Verhaltenserfassung

Beobachtungsdauer max. 20min, 25 Tiere pro Punkt, Beurteilung zum Ende

\begin{tabular}{|c|c|c|c|c|c|c|c|c|}
\hline $\begin{array}{c}\text { Beobachtungs- } \\
\text { punkt: }\end{array}$ & 1 & 2 & 3 & 4 & 5 & 6 & 7 & 8 \\
\hline $\begin{array}{c}\text { Beobachtungs- } \\
\text { dauer: }\end{array}$ & 10 & 10 & 6,5 & 5 & 4 & 3,5 & 3 & 2,5 \\
\hline
\end{tabular}

\begin{tabular}{|c|c|c|}
\hline Beobachtet & Minimum & Maximum \\
\hline aktiv & & \\
\hline entspannt & & \\
\hline ängstlich & & \\
\hline aufgeregt & & \\
\hline ruhig & & \\
\hline zufrieden & & \\
\hline gleichgültig & & \\
\hline frustriert & & \\
\hline freundlich & & \\
\hline gelangweilt & & \\
\hline verspielt & & \\
\hline positiv & & \\
\hline lebhaft & & \\
\hline neugierig & & \\
\hline reizbar & & \\
\hline unbehaglich & & \\
\hline gesellig & & \\
\hline teilnahmslos & & \\
\hline fröhlich & & \\
\hline betrübt & & \\
\hline
\end{tabular}


Betrieb:

Tier-Nummer:

Body Condition:

Datum:

\begin{tabular}{|l|l|l|}
\hline 1 & 0 & 2 \\
\hline
\end{tabular}

Sauberkeit:

$\square$ linke $\square$ rechte Seite

\begin{tabular}{|l|c|c|}
\hline $\begin{array}{l}\text { unteres Hinterbein, } \\
\text { Schwanzquaste }\end{array}$ & 0 & 2 \\
\hline $\begin{array}{l}\text { oberes Hinterbein, Flanke, } \\
\text { Hinterteil mit Schwanz }\end{array}$ & 0 & 2 \\
\hline Euter & 0 & 2 \\
\hline
\end{tabular}

Integumentschäden

$\square$ linke $\square$ rechte Seite

rechte Seite

Tier:

Leistungsgruppe:

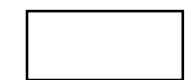

\begin{tabular}{|l|l|l|l|}
\hline & Haarlose Stellen & Läsionen & Schwellungen \\
\hline Hinterfußregion & & & \\
\hline Hinterteil & & & \\
\hline Flanke/Seite/Euter & & & \\
\hline Nacken/Schulter/Rücken & & & \\
\hline Vorderfußregion & & & \\
\hline
\end{tabular}

Krankheiten

\begin{tabular}{|c|l|c|c|}
\hline Nasenausfluss & & Tränenfluss & \\
\hline Erschwertes Atmen & & Durchfall & \\
\hline Vulvaausfluss & & \multicolumn{2}{|c}{} \\
\cline { 1 - 2 }
\end{tabular}

Lahmheit

\begin{tabular}{|l|l|l|}
\hline 0 & 1 & 2 \\
\hline
\end{tabular}




\section{Managementfragebogen - Milchviehhaltung}

\begin{tabular}{|c|c|c|}
\hline 1.1 & Betriebsspiegel & \\
\hline 1.1 .1 & Betriebsname & \\
\hline 1.1 .2 & Emailadresse & {$[\ldots \ldots \ldots \ldots \ldots \ldots \ldots \ldots \ldots \ldots \ldots \ldots \ldots \ldots \ldots \ldots \ldots \ldots \ldots \ldots \ldots \ldots \ldots \ldots \ldots$} \\
\hline 1.1 .3 & Kontaktdaten & Tel.: $\ldots \ldots \ldots \ldots \ldots \ldots \ldots \ldots, \quad$ Fax.: $\ldots \ldots \ldots \ldots \ldots \ldots \ldots \ldots \ldots \ldots$ \\
\hline 1.1 .4 & Betriebsfläche (Hektar LN) & $\begin{array}{l}\text { Gesamtfläche des Betriebs: } \quad \ldots \ldots \ldots \ldots \ldots \ldots \ldots \ldots \text { ha } \\
\text { Grünland: } \ldots \ldots \ldots \ldots \text { ha } \quad \text { Ackerland: } \ldots \ldots \ldots \ldots \ldots \text { ha }\end{array}$ \\
\hline 1.1 .5 & Rechtsform des Unternehmens & $\begin{array}{l}\square \text { Einzelunternehmen (Familienbetrieb) } \\
\square \text { Personengesellschaft (z.B. GbR, KG) } \\
\square \quad \text { Agrargenossenschaft (z.B. e.G.) }\end{array}$ \\
\hline 1.1 .6 & Betriebszweige im Unternehmen & 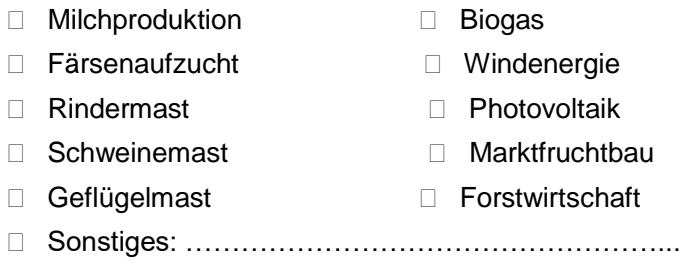 \\
\hline 1.1 .7 & Anteil Milchproduktion an Einkommen & $\square<25 \% \quad \square 25-50 \% \quad \square \quad 51-75 \% \quad \square>75 \%$ \\
\hline 1.1 .8 & Betriebsform des Unternehmens & $\begin{array}{ll}\square & \text { Familienbetrieb (0 Fremd-Arbeitskraft) } \\
\square \text { erweiterter Familienbetrieb (1 Fremd-Arbeitskraft) } \\
\square \quad \text { Lohnarbeitsbetrieb (> 1 Fremd-Arbeitskraft) }\end{array}$ \\
\hline
\end{tabular}

\begin{tabular}{|c|c|c|}
\hline 1.1 .9 & $\begin{array}{l}\text { Arbeitskräfte (addiert zu Vollzeit-Arbeits- } \\
\text { stellen) }\end{array}$ & $\begin{array}{llll}\text { Arbeitskräfte in Milchproduktion: } & \ldots \ldots \ldots \ldots \ldots & \text { AK } \\
\text { davon: } & \text { - Betriebsleiter: } & \ldots \ldots \ldots \ldots \ldots & \text { AK } \\
& \text { - Familien-AK: } & \ldots \ldots \ldots \ldots \ldots & \text { AK } \\
& \text { - Herdenmanager: } & \ldots \ldots \ldots \ldots \ldots & \text { AK } \\
& \text { - Melker/-innen: } & \ldots \ldots \ldots \ldots \ldots & \text { AK } \\
& \text { - Fütterer etc.: } & \ldots \ldots \ldots \ldots \ldots & \text { AK } \\
& \text { - Auszubildende: } & \ldots \ldots \ldots \ldots \ldots & \text { AK }\end{array}$ \\
\hline 1.1.10 & $\begin{array}{l}\text { Streben Sie in den nächsten } 5 \text { Jahren eine } \\
\text { Stallerweiterung oder einen Stallneubau } \\
\text { an? }\end{array}$ & $\square$ vielleicht \\
\hline 1.1.11 & $\begin{array}{l}\text { Soll die Herdengröße in den nächsten } 5 \\
\text { Jahren verändert werden? }\end{array}$ & $\square$ vielleicht \\
\hline 1.1 .12 & $\begin{array}{l}\text { Wenn ja, wie wird sich die Herdengröße in } \\
\text { den nächsten } 5 \text { Jahren verändern? }\end{array}$ & $\begin{array}{l}\square \text { Aufstocken } \quad \text { um } \quad \ldots \ldots \ldots \ldots \text { Tiere } \\
\square \text { Abstocken } \quad \text { um } \quad \ldots \ldots \ldots \ldots \text { Tiere }\end{array}$ \\
\hline 1.2 & Betriebsleitung & \\
\hline 1.2 .1 & Name des Betriebsleiters & \\
\hline 1.2 .2 & Alter des Betriebsleiters & Geburtsjahr $19 \ldots \ldots \ldots$. \\
\hline 1.2 .3 & Geschlecht des Betriebsleiters & $\square$ Männlich \\
\hline 1.2 .4 & Ausbildung des Betriebsleiters & $\begin{array}{l}\square \text { keine Ausbildung } \square \text { Ausbildung } \square \text { Meisterprüfung } \square \\
\text { Fachhochschul-Abschluss } \square \text { Hochschulabschluss } \square \\
\text { Sonstiges: } \quad \text {..................................... }\end{array}$ \\
\hline 1.2 .5 & Berufserfahrung des Betriebsleiters & 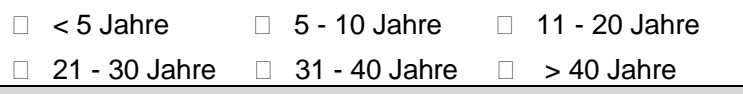 \\
\hline 2.1 & FÜTTERUNG - Allgemein & \\
\hline 2.1 .1 & Wie oft werden die Kühe gefüttert? & .... Mal / Tag \\
\hline 2.1 .2 & Wie oft wird das Futter rangeschoben? & $\ldots \ldots \ldots \ldots \ldots \ldots . \quad$ Mal / Tag \\
\hline
\end{tabular}




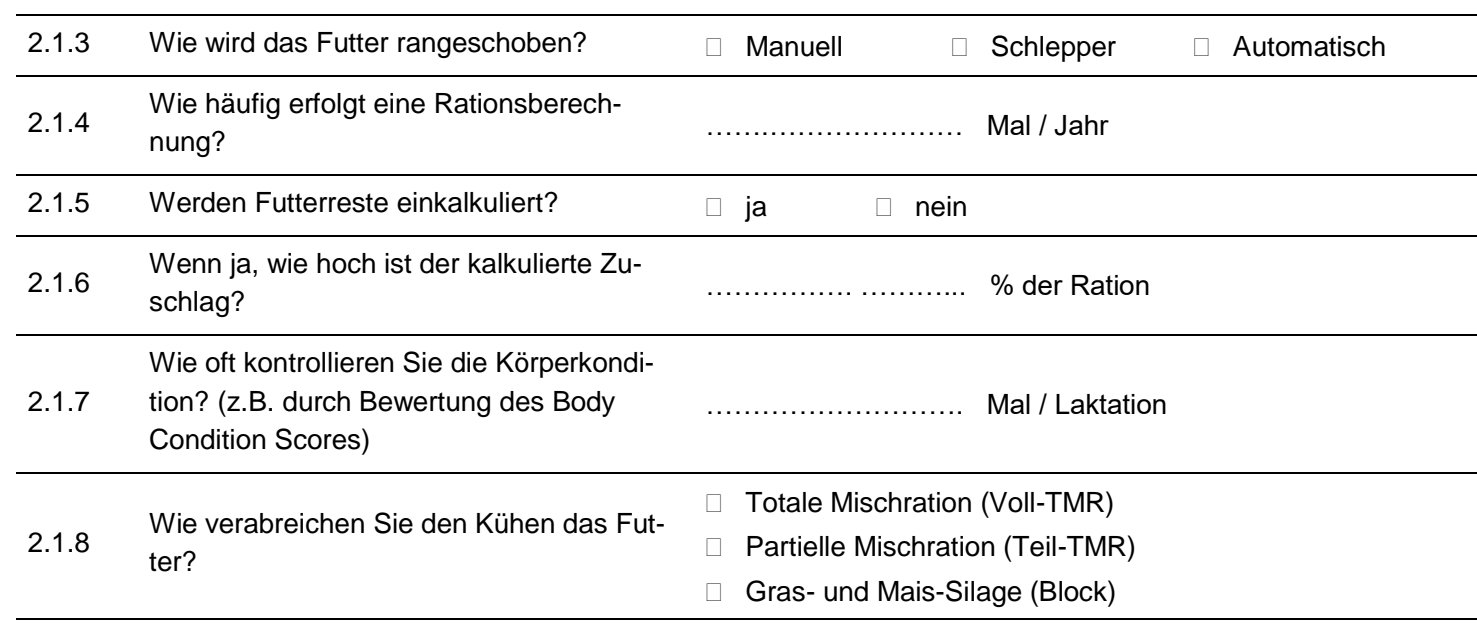

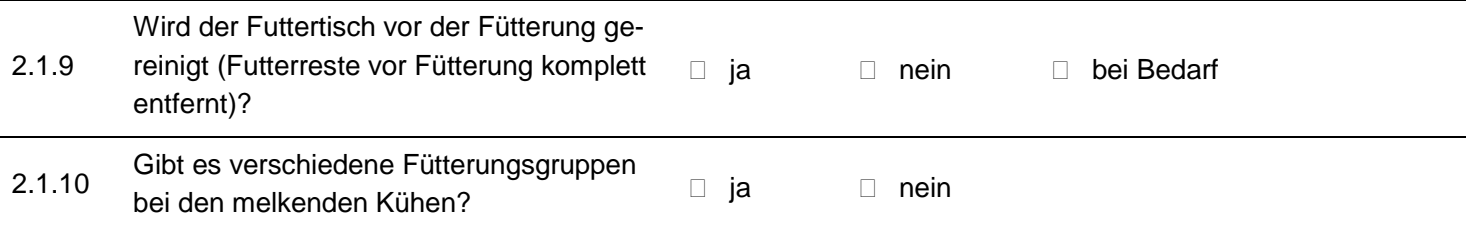

Wenn ja, wie viele Fütterungsgruppen gibt

2.1.11 es bei den melkenden Kühen (= Anzahl Rationen)?

\section{Fütterungsgruppen}

Leistung (Frischmelker, Altmelker etc.)

Körperkondition (Body Condition Score)

Laktationsstufen (Färsen, Altkühe)

sonstige Einteilungen: ...................

\begin{tabular}{|c|c|c|}
\hline 2.1 .13 & $\begin{array}{l}\text { Nehmen Sie regelmäßig Kotproben (Sieb- } \\
\text { test)? }\end{array}$ & $\square$ nein \\
\hline 2.2 & FÜTTERUNG - Grundfutter & \\
\hline 2.2 .1 & $\begin{array}{l}\text { Wie oft lassen Sie Ihr Grundfutter untersu- } \\
\text { chen? }\end{array}$ & $\ldots \ldots \ldots \ldots \ldots$ Mal / Jahr bzw. .............. Mal / Silo \\
\hline 2.2 .2 & $\begin{array}{l}\text { Wie häufig nutzen Sie einen Siliermittelzu- } \\
\text { satz? }\end{array}$ & $\square$ immer $\quad \square$ niemals $\quad \square$ bei Bedarf \\
\hline 2.2.3 & Wie wird die Silage gelagert (Standort)? & $\begin{array}{l}\square \quad \text { Befestigter Untergrund (Asphalt, Beton, Steine) } \\
\quad \text { Unbefestigter Untergrund (Grünland, Erdboden) }\end{array}$ \\
\hline 2.2 .4 & $\begin{array}{l}\text { Bieten Sie den melkenden Kühen zusätzli- } \\
\text { ches Rau-futter an (z.B. Heuraufe, Futter- } \\
\text { stroh)? }\end{array}$ & $\square$ nein \\
\hline 2.3 & FÜTTERUNG - Kraftfutter & \\
\hline 2.3.1 & $\begin{array}{l}\text { Wie ist das mittlere Verhältnis von Grund- } \\
\text { futter zu Kraftfutter in der Ration (Bezug = } \\
\text { Trockenmasse)? }\end{array}$ & $\begin{array}{l}\text { (........... \% Grundfutter : .......... \% Kraftfutter } \\
\text { (z.B. 80\%:20\%; 66\%:34\%; 50\%:50\%; 48\%:52\% etc.) }\end{array}$ \\
\hline 2.3.2 & $\begin{array}{l}\text { Durchschnittlicher Kraftfutteraufwand pro } \\
\text { Kuh }\end{array}$ & ........ kg / Kuh / Tag \\
\hline 2.3.3 & $\begin{array}{l}\text { Maximaler Kraftfutteraufwand pro Kuh und } \\
\text { Tag }\end{array}$ & .... kg / Kuh / Tag \\
\hline 2.3.4 & Wie erfolgt die Kraftfuttergabe? & $\begin{array}{ll}\square \text { in Kraftfutterstation } & \square \text { im Melkstand } \\
\square \text { in der Mischration } & \square \text { per Schaufel }\end{array}$ \\
\hline 2.3.5 & Erhalten die Kühe zusätzlich Mineralfutter? & $\square$ bei Bedarf \\
\hline
\end{tabular}




\begin{tabular}{|c|c|c|}
\hline 2.3.6 & $\begin{array}{l}\text { Wie erhalten die Kühe zusätzlich Mineral- } \\
\text { futter? }\end{array}$ & $\square$ Leckschalen $\quad \square$ Lecksteine $\quad \square$ per Mischration \\
\hline 2.4 & FÜTTERUNG - Tränken & \\
\hline 2.4.1 & $\begin{array}{l}\text { Wie oft werden die Tränken im Stall kon- } \\
\text { trolliert (Funktionsfähigkeit, Verschmut- } \\
\text { zung)? }\end{array}$ & Mal / Tag \\
\hline 2.4 .2 & $\begin{array}{l}\text { Wie oft werden die Tränken grob gereinigt } \\
\text { (z.B. Wasser ablassen und Futterreste ent- } \\
\text { fernen)? }\end{array}$ & Mal / Tag \\
\hline 2.4 .3 & $\begin{array}{l}\text { Wie oft werden die Tränken gründlich ge- } \\
\text { reinigt (z.B. mit Bürste oder Schwamm)? }\end{array}$ & ... Mal / Woche \\
\hline 2.4.4 & $\begin{array}{l}\text { Woher kommt das Wasser für die Trän- } \\
\text { ken? }\end{array}$ & $\square \quad$ Leitungswasser \\
\hline 2.4 .5 & Wie oft wird die Wasserqualität überprüft? & .... Mal / Jahr \\
\hline 2.4.6 & $\begin{array}{l}\text { Sind die Tränken frostsicher (z.B. mit Heiz- } \\
\text { stab)? }\end{array}$ & $\square$ teilweise \\
\hline 3.1 & HALTUNG - Stallgebäude & \\
\hline 3.1.1 & $\begin{array}{l}\text { In welchem Jahr wurde der Stall für die } \\
\text { melkenden Kühe gebaut? (Anbauten als } \\
\text { Gebäude angeben) }\end{array}$ & $\begin{array}{l}\text { Stall } 1: \quad \ldots \ldots \ldots \ldots \ldots \ldots \ldots \ldots \\
\text { Stall } 2: \quad \ldots \ldots \ldots \ldots \ldots \ldots \ldots \ldots \ldots\end{array}$ \\
\hline 3.1 .2 & $\begin{array}{l}\text { Wurden seitdem größere Baumaßnahmen } \\
\text { (z.B. Liegeboxen) durchgeführt und in wel- } \\
\text { chem Jahr? }\end{array}$ & 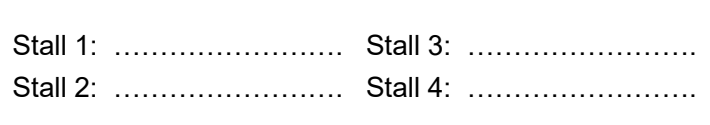 \\
\hline 3.1 .3 & Sind im Stallgebäude Lüfter angebracht? & $\square$ nein $\quad \square$ teilweise \\
\hline 3.1 .4 & Wie werden die Lüfter eingeschaltet? & $\square$ automatisch \\
\hline 3.1 .5 & $\begin{array}{l}\text { Sind seitliche Vorhänge (Curtains) ange- } \\
\text { bracht? }\end{array}$ & $\square$ teilweise \\
\hline 3.1 .6 & $\begin{array}{l}\text { Wie werden die Vorhänge (Curtains) be- } \\
\text { wegt? }\end{array}$ & $\square$ automatisch \\
\hline 3.1 .7 & Gibt es im Stallgebäude Sprinkleranlagen? & $\square$ teilweise \\
\hline 3.1 .8 & $\begin{array}{l}\text { Wie wird die Sprinkleranlage eingeschal- } \\
\text { tet? }\end{array}$ & $\square$ automatisch \\
\hline 3.1 .9 & Ist das Dach des Stallgebäudes gedämmt? & $\square$ teilweise \\
\hline 3.1 .10 & $\begin{array}{l}\text { Gibt es im Stallgebäude ein Lichtpro- } \\
\text { gramm? }\end{array}$ & $\square$ teilweise \\
\hline 3.1 .11 & $\begin{array}{l}\text { Wie wird das Lichtprogramm eingeschal- } \\
\text { tet? }\end{array}$ & $\square$ automatisch \\
\hline 3.1.12 & Wie ist das Lichtprogramm eingestellt? & Stunden Nacht: .......... Stunden \\
\hline 3.1 .13 & $\begin{array}{l}\text { Welche Leuchtmittel gibt es im Stallge- } \\
\text { bäude? }\end{array}$ & $\begin{array}{l}\square \text { Glühbirnen } \quad \square \text { Leuchtröhren } \quad \square \text { Dampflampen } \\
\square \text { LED-Leuchten } \quad \square \text { Sonstiges: ......................... }\end{array}$ \\
\hline 3.2 & HALTUNG - Liegeboxen & \\
\hline 3.2 .1 & Boxenbauweise (Anteil in \%) & 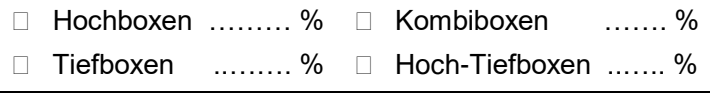 \\
\hline 3.2 .2 & $\begin{array}{l}\text { Woraus besteht die Auflage der Hochbo- } \\
\text { xen? }\end{array}$ & $\square$ Schaumstoff \\
\hline 3.2.3 & Wie oft werden die Hochboxen gepflegt? & ..... Mal / Tag \\
\hline
\end{tabular}




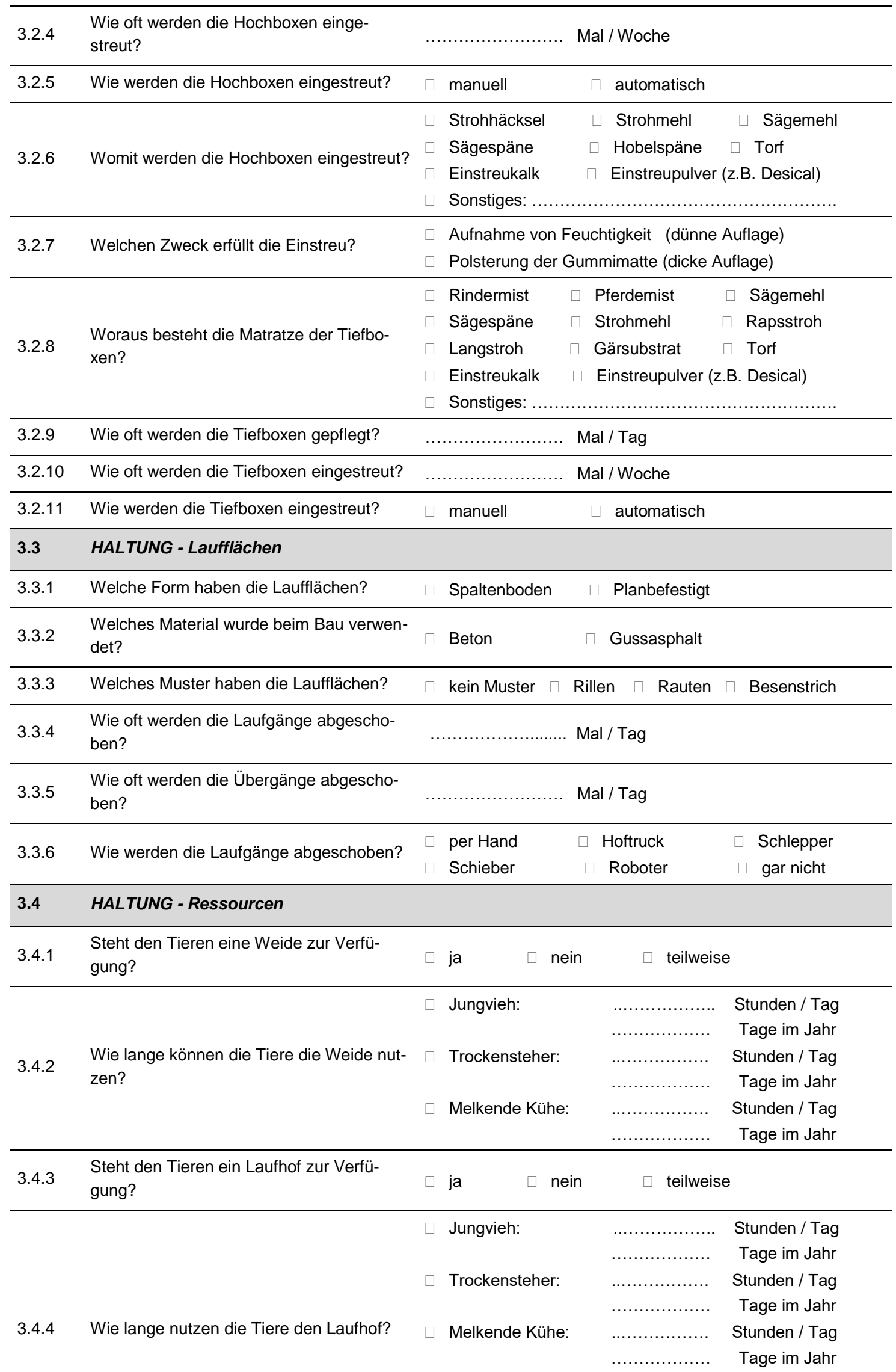




\subsection{GESUNDHEIT - Klauenpflege}

4.1.1 Wie oft werden die Klauen jeder einzelnen

Kuh pro Jahr im Durchschnitt gepflegt?

Mal / Jahr

In welchem Abstand werden die Klauen je-

4.1.2 der einzelnen Kuh im Durchschnitt ge- alle pflegt?

alle .

Monate

4.1.3 In welcher Form werden die Klauen der Tiere normalerweise gepflegt?

$\square$ Herdenschnitt (alle Tiere einer Herde gleichzeitig)

$\square$ Kontinuierlich (Einzeltiere zu verschiedenen Zeiten)

$\checkmark$ nach Bedarf (bei akuten Lahmheitsanzeichen)

\begin{tabular}{llllll}
\hline 4.1.4 & Wer schneidet die Klauen normalerweise? & $\square$ Klauenpfleger & $\square$ Landwirt & $\square$ Tierarzt \\
\hline 4.1 .5 & $\begin{array}{l}\text { Führen Sie regelmäßig Klauenbäder } \\
\text { durch? }\end{array}$ & $\square$ ja & $\square$ nein & $\square$ bei Bedarf \\
\hline
\end{tabular}

4.1.6 Wie oft werden Klauenbäder durchgeführt? ..................... Mal / Monat

4.2 GESUNDHEIT - Vorsorge

\begin{tabular}{|c|c|c|c|}
\hline 4.2 .1 & $\begin{array}{l}\text { Kaufen Sie Tiere von anderen Betrieben } \\
\text { zu? }\end{array}$ & $\square$ ja & $\square$ nein \\
\hline 4.2.2 & $\begin{array}{l}\text { Gibt es für neue Tiere einen Quarantäne- } \\
\text { stall? }\end{array}$ & $\square$ ja & $\square$ nein \\
\hline 4.2 .3 & $\begin{array}{l}\text { Werden die neuen Tiere tierärztlich unter- } \\
\text { sucht? }\end{array}$ & $\square$ ja & $\square$ nein \\
\hline 4.2.4 & $\begin{array}{l}\text { Trat in den letzten } 5 \text { Jahren eine Seuche } \\
\text { auf? }\end{array}$ & $\square$ ja & $\square$ nein \\
\hline
\end{tabular}

\begin{tabular}{|c|c|c|}
\hline 4.2 .5 & $\begin{array}{l}\text { Wenn ja, welche Seuche trat im Betrieb } \\
\text { auf? }\end{array}$ & \\
\hline 4.2 .6 & Gibt es ein Hygienekonzept für Besucher? & $\square$ nein \\
\hline 4.2.7 & $\begin{array}{l}\text { Wenn ja, welche Maßnahmen sind vorge- } \\
\text { sehen? }\end{array}$ & $\begin{array}{l}\square \text { Besucherkleidung } \square \text { Besucherstiefel } \\
\square \text { Stiefeldesinfektion } \quad \square \text { Sonstiges: ........ }\end{array}$ \\
\hline 4.2 .8 & Impfen Sie die Herde regelmäßig? & $\square$ nein \\
\hline 4.2 .9 & Wenn ja, gegen welche Krankheiten? & \\
\hline 4.2.10 & Bekämpfen Sie regelmäßig Schadnager? & $\square$ nein \\
\hline 4.2 .11 & Wie oft wird das Fell der Kühe geschoren? & ...... Mal / Jahr \\
\hline 4.2.12 & Wie oft werden die Schwänze geschoren? & Mal / Jahr \\
\hline 4.2 .13 & Wie oft werden die Euterhaare entfernt? & $\ldots \ldots \ldots \ldots \ldots \ldots \ldots \ldots \ldots \ldots \ldots \ldots$ Mal / Jahr \\
\hline 4.3 & GESUNDHEIT - Behandlung & \\
\hline 4.3 .1 & Gibt es einen separaten Krankenbereich? & $\square$ nein \\
\hline 4.3 .2 & $\begin{array}{l}\text { Wird dieser Bereich auch für Abkalbungen } \\
\text { genutzt? }\end{array}$ & $\square$ nein \\
\hline 4.3 .3 & Wie ist der Krankenbereich strukturiert? & $\square$ Einzelboxen $\quad \square$ Gruppenboxen \\
\hline 4.3 .4 & $\begin{array}{l}\text { Wie groß ist der Krankenbereich insge- } \\
\text { samt? }\end{array}$ & $\ldots \ldots \ldots \ldots \ldots m^{2}$ für $\ldots \ldots \ldots \ldots \ldots$ Tiere \\
\hline 4.3.5 & $\begin{array}{l}\text { Wie oft wird der Krankenbereich normaler- } \\
\text { weise gereinigt und desinfiziert? }\end{array}$ & $\begin{array}{l}\square \text { nach jeder Belegung (Rein-Raus-Verfahren) } \\
\square \text { nach Bedarf (wenn Boxen schmutzig sind) }\end{array}$ \\
\hline 4.3.6 & $\begin{array}{l}\text { Gibt es Fixiermöglichkeiten für Behandlun- } \\
\text { gen? }\end{array}$ & $\ldots \ldots \ldots \ldots \ldots \ldots \ldots \ldots \ldots \ldots \ldots \ldots$ Plätze (z.B. Selbstfangfressgitter) \\
\hline
\end{tabular}




\begin{tabular}{|c|c|c|}
\hline 4.3.7 & $\begin{array}{l}\text { Welche Tiere werden gegen Endoparasi- } \\
\text { ten (z.B. Lungenwurm, Magendarmwurm) } \\
\text { behandelt? }\end{array}$ & $\square$ Trockensteher $\square$ Melkende Kühe \\
\hline 4.3 .8 & $\begin{array}{l}\text { Bei welchen Tieren werden Ektoparasiten } \\
\text { (z.B. Fliegen, Mücken, Milben, Läuse) be- } \\
\text { handelt? }\end{array}$ & $\square$ Trockensteher $\square$ Melkende Kühe \\
\hline \multirow[t]{2}{*}{5.1} & MANAGEMENT - Melktechnik & \\
\hline & & $\square$ Fischgräte $\quad \square$ Side by Side $\quad \square$ Swing-Over \\
\hline \multirow[t]{2}{*}{5.1 .1} & Welche Art von Melkstand besitzen Sie? & $\square$ Außenmelkerkarussell $\quad \square$ Innenmelkerkarussell \\
\hline & & $\square$ Melkroboter $\square$ Sonstiges: ........ \\
\hline 5.1 .2 & Wann wurde die Melktechnik eingebaut? & ........ (Jahreszahl) \\
\hline 5.1 .3 & Wie viele Melkgeschirre sind vorhanden? & $\ldots \ldots \ldots \ldots \ldots \ldots \ldots \ldots \ldots \ldots \ldots$ Melkgeschirre \\
\hline 5.1 .4 & Gibt es ein Milchmengenmessgerät? & $\square$ nein \\
\hline 5.1 .5 & Gibt es ein Leitfähigkeitsmessgerät? & $\square$ nein \\
\hline 5.1 .6 & Gibt es eine Abnahmeautomatik? & $\square$ nein \\
\hline 5.1 .7 & Wie funktioniert die Abnahmeautomatik? & $\square$ gesamtes Melkgeschirr $\quad \square$ einzelne Melkbecher \\
\hline 5.1 .8 & $\begin{array}{l}\text { Wird eine Zwischendesinfektion durchge- } \\
\text { führt? }\end{array}$ & $\square$ nein \\
\hline 5.1 .9 & Wie erfolgt die Zwischendesinfektion? & $\square$ automatisch \\
\hline 5.1 .10 & Womit erfolgt die Zwischendesinfektion? & $\square$ Kaltwasser $\square$ Heißwasser $\square$ Desinfektionsmittel \\
\hline 5.1 .11 & $\begin{array}{l}\text { Aus welchem Material sind die Zitzengum- } \\
\text { mis? }\end{array}$ & $\square$ Gummi \\
\hline
\end{tabular}

\begin{tabular}{ll}
\hline 5.1 .12 & $\begin{array}{l}\text { Wie häufig wechseln Sie die Zitzengum- } \\
\text { mis? }\end{array}$ \\
\hline $\mathbf{5 . 2}$ & MANAGEMENT - Melkroutine
\end{tabular}

\begin{tabular}{|c|c|c|}
\hline 5.2 .1 & $\begin{array}{l}\text { Wie oft wird pro Tag wird die Herde gemol- } \\
\text { ken? }\end{array}$ & Mal / Tag \\
\hline 5.2 .2 & Wie lange dauert im Schnitt eine Melkzeit? & ... Stunden bzw. .............. Minuten \\
\hline 5.2 .3 & Wie viele Melker arbeiten pro Melkzeit? & ...... Melker \\
\hline 5.2 .4 & $\begin{array}{l}\text { Wie werden die Kühe zum Melken getrie- } \\
\text { ben? }\end{array}$ & $\square$ automatisch \\
\hline 5.2 .5 & $\begin{array}{l}\text { Gibt es einen separaten Vorwartehof } \\
\text { (VWH)? }\end{array}$ & $\square$ nein \\
\hline 5.2 .6 & $\begin{array}{l}\text { Wie groß ist der separate Vorwartehof } \\
\text { (VWH)? }\end{array}$ & $\ldots \mathrm{m}^{2}$ \\
\hline 5.2 .7 & $\begin{array}{l}\text { Wie viele Kühe sind maximal im Vorwarte- } \\
\text { hof? }\end{array}$ & Kühe \\
\hline 5.2 .8 & $\begin{array}{l}\text { Wie lange sind die Kühe maximal im } \\
\text { VWH? }\end{array}$ & Minuten \\
\hline 5.2 .9 & Wie werden die Kühe im VWH getrieben? & $\square$ automatisch \\
\hline 5.2 .10 & Hat der Melkstand einen Schnellaustrieb? & $\square$ nein \\
\hline 5.2 .11 & Welche Schritte umfasst die Melkroutine? & $\begin{array}{ll}\square \text { Zitzenreinigung } & \square \text { Vordippen } \quad \square \text { Vormelken } \\
\square \text { Nachdippen } & \square \text { Sonstiges: ............................. }\end{array}$ \\
\hline 5.2 .12 & Womit erfolgt die Zitzenreinigung? & $\square$ Mehrwegtücher \\
\hline
\end{tabular}




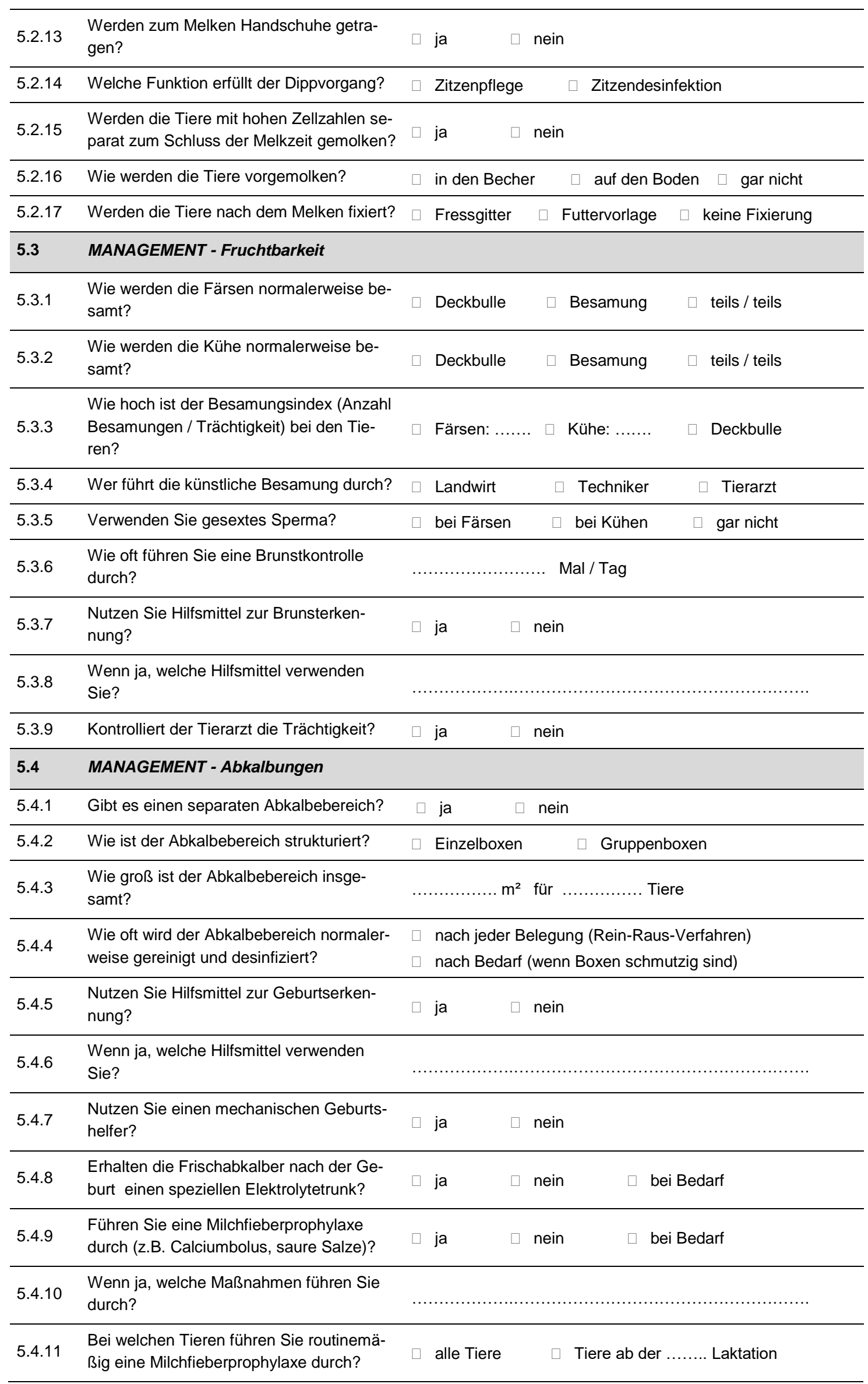




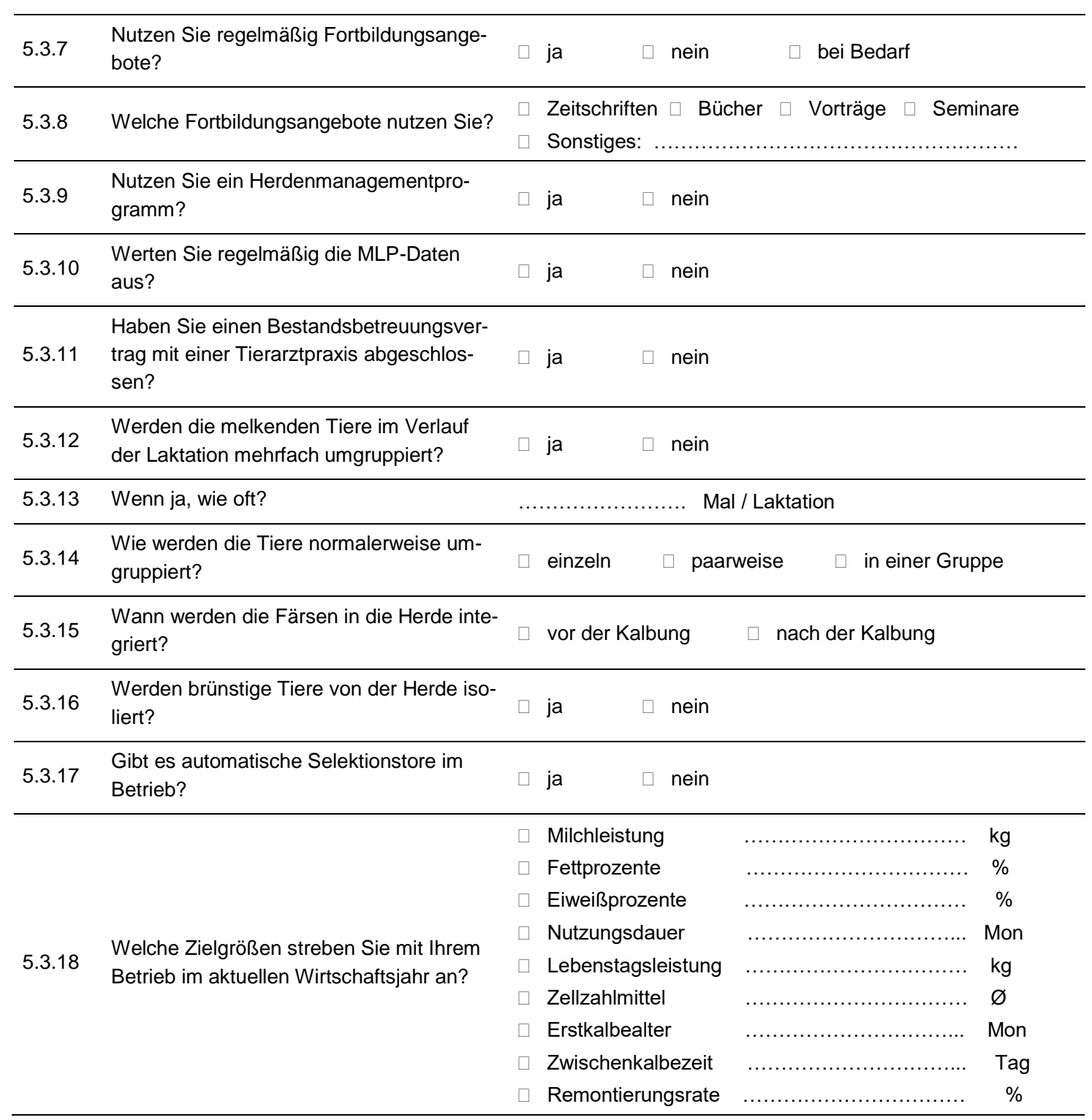




\section{Eidesstattliche Erklärung}

1. Hiermit erkläre ich, dass diese Arbeit weder in gleicher noch in ähnlicher Form bereits anderen Prüfungsbehörden vorgelegen hat.

Weiter erkläre ich, dass ich mich an keiner anderen Hochschule um einen Doktorgrad beworben habe.

Göttingen, den 27. September 2018

Daniel Gieseke

2. Hiermit erkläre ich eidesstattlich, dass diese Dissertation selbständig und ohne unerlaubte Hilfe angefertigt wurde.

Göttingen, den 27. September 2018

Daniel Gieseke 